Prepared in cooperation with Cascade Water Alliance

\title{
Quality of Water in the White River and Lake Tapps, Pierce County, Washington, May-December 2010
}

Scientific Investigations Report 2012-5022 
Cover:

Photograph of Lake Tapps, Washington, with Mount Rainier in the background.

(Photograph taken by Ryan Burge, private citizen, December 31, 2011.) 


\section{Quality of Water in the White River and Lake Tapps, Pierce County, Washington, May-December 2010}

By S.S. Embrey, R.J. Wagner, R.L. Huffman, A.M. Vanderpool-Kimura, and J.R. Foreman

Prepared in cooperation with Cascade Water Alliance

Scientific Investigations Report 2012-5022 


\title{
U.S. Department of the Interior \\ KEN SALAZAR, Secretary \\ U.S. Geological Survey \\ Marcia K. McNutt, Director
}

\author{
U.S. Geological Survey, Reston, Virginia: 2012
}

For more information on the USGS - the Federal source for science about the Earth, its natural and living resources, natural hazards, and the environment, visit http://www.usgs.gov or call 1-888-ASK-USGS.

For an overview of USGS information products, including maps, imagery, and publications, visit http://www.usgs.gov/pubprod

To order this and other USGS information products, visit http://store.usgs.gov

Any use of trade, product, or firm names is for descriptive purposes only and does not imply endorsement by the U.S. Government.

Although this report is in the public domain, permission must be secured from the individual copyright owners to reproduce any copyrighted materials contained within this report.

Suggested citation:

Embrey, S.S., Wagner, R.J., Huffman, R.L., Vanderpool-Kimura, A.M., and Foreman, J.R., 2012, Quality of water in the White River and Lake Tapps, Pierce County, Washington, May-December 2010: U.S. Geological Survey Scientific Investigations Report 2012-5022, 118 p. 


\section{Contents}

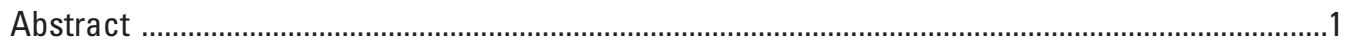

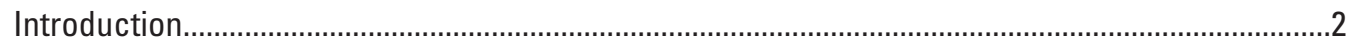

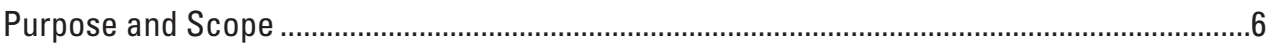

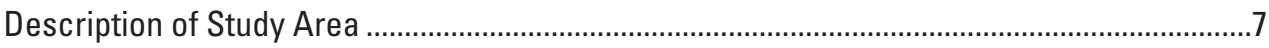

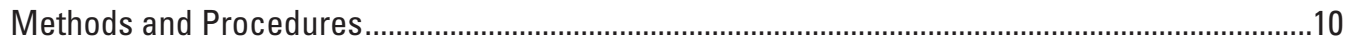

River Continuous Monitors........................................................................................................10

Turbidimeter and Vertical Profiling Instruments for River and Lake Measurements ..............11

Field-Trip Preparation, Sample-Collection, and Sample-Handling Protocols..........................11

Post-Field Trip Sample Processing and Handling .......................................................................11

Post-Field Trip Vertical Profiling Instrument Maintenance and Data Processing..................12

Processing of Vertical Profiling Instrument Data Files.....................................................12

River, Canal, and Diversion Water Sampling and Onsite Processing .....................................12

Lake Water Sampling and Onsite Processing.......................................................................12

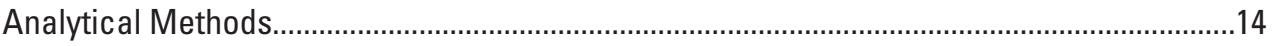

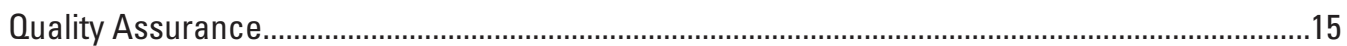

Field Quality Control Samples ........................................................................................... 15

Laboratory Quality Control Samples .......................................................................................17

Analytical Results for Quality Control Samples .....................................................................17

Environmental and Hydrologic Conditions During the Sample-Collection Period ............................21

Quality of Water in the White River, White River Canal, Lake Tapps Diversion, and

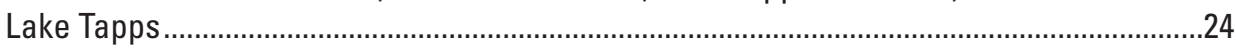

Quality of Water in the White River (Headworks), White River Canal (Inflow), and Lake Tapps Diversion (Tailrace)—Discrete Samples ..........................................................24

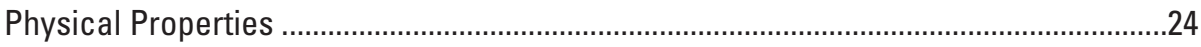

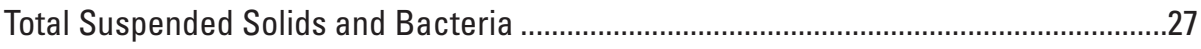

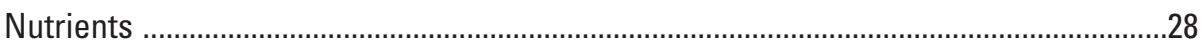

Quality of Water in the White River and Lake Tapps Diversion (Tailrace)-

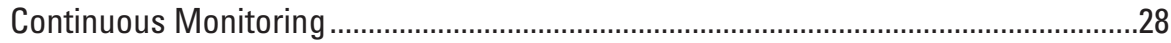

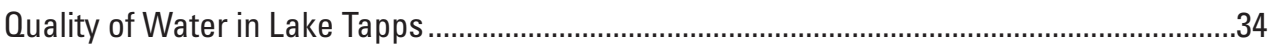

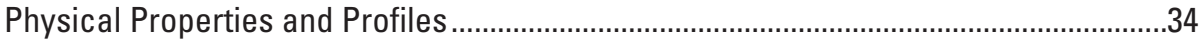

Total Suspended Solids and Fecal-Coliform Bacteria .....................................................42

Nutrients and Chlorophyll a .............................................................................................43

Variations in Water-Quality Properties and Constituents over Time.................................45

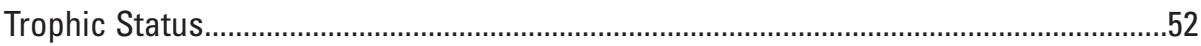

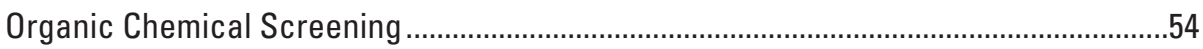

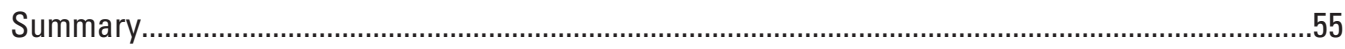

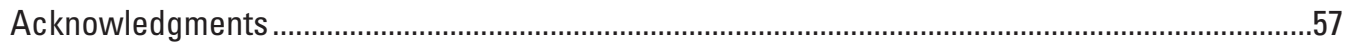

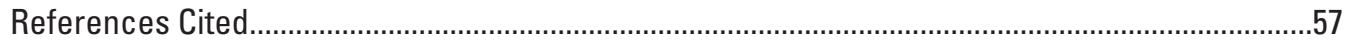




\section{Contents-Continued}

Appendix A. Field Notes and Observations Recorded during Sampling of the Nine Sites on Lake Tapps, Washington, July-December 2010.

Appendix B. Parameter Codes, Analytical Methods, and Reporting Levels for Analytes in National Water Quality Laboratory Schedule 1865 (Nutrients) and Schedule 1637 (Chlorophyll $a$ and Pheophytin a)...

Appendix C. Parameter Codes and Reporting Levels for Organic-Compound Analytes in National Water Quality Laboratory Schedule 2033 (Moderate-Use Pesticides), Schedule 2060 (Polar Pesticides), Schedule 1433 (Wastewater Indicators), Schedule 2080 (Human-Health Pharmaceuticals), and Lab Code 8144 (Human-Health Pharmaceuticals)

Appendix D. Analytical Results for Quality-Control Samples Collected at White River at Headworks, White River Canal, Lake Tapps Diversion, and Lake Tapps, Washington Study Sites, July-December 2010

Appendix E. Seven-Day Average of Daily Maximum Temperatures on the White River at Headworks, White River at R Street, and Lake Tapps Diversion (Tailrace), Washington, May-December 2010

Appendix F. Vertical Profiles of Water-Quality Properties with Depth for Selected Sampling Dates at Nine Sites on Lake Tapps, Washington

Appendix G. Pesticides, Wastewater Indicator Chemicals, and Human-Health Pharmaceuticals in Samples from Allan Yorke (map No. L2), Snag Island (map No. L5), and Lake Outlet (map No. L8) Study Sites on Lake Tapps, Washington, September 2010

\section{Figures}

Figure 1. Map showing U.S. Geological Survey surface-water and lake-elevation gaging stations in the White River basin, Pierce County, Washington

Figure 2. Graph showing average discharge at White River Canal (Headworks) and Lake Tapps Diversion at Dieringer (Tailrace), Washington, water years 1982-2010

Figure 3. Map showing continuous and discrete water-quality study sites on the White River at Headworks, White River at R Street, White River Canal, and Lake Tapps Diversion, Washington

Figure 4. Map showing locations of study sites on Lake Tapps, Washington 9

Figure 5. Photographs showing Sea-Bird conductance, temperature, depth (CTD) profiling instrument assembly and deployment while monitoring real-time data output

Figure 6. Graph showing daily rainfall amounts from precipitation records at McMillin Reservoir near Puyallup, Washington, June-December 2010

Figure 7. Photographs showing Lake Tapps Diversion downstream of the Dieringer powerhouse (Tailrace) at no-flow, stagnant condition and at a flow of 100 cubic feet per second 23

Figure 8. Daily discharge hydrograph for stream-gaging station 12101100, Lake Tapps Diversion at Dieringer (Tailrace), Washington, May-December 2010 24 


\section{Figures-Continued}

Figure 9. Graph showing seven-day average of daily maximum water temperatures at White River at the Headworks, White River at R Street, and Lake Tapps Diversion at Dieringer (Tailrace), Washington, May-December 2010

Figure 10. Graph showing minimum, maximum, and mean dissolved oxygen concentrations at White River at Headworks, Washington, May-December 2010

Figure 11. Graph showing minimum, maximum, and mean disolved oxygen at Lake Tapps Diversion at Dieringer (Tailrace), Washington, May-December 2010 ............ 31

Figure 12. Graph showing minimum, maximum, and median $\mathrm{pH}$ at White River at Headworks, Washington, May-December 2010 32

Figure 13. Graph showing minimum, maximum, and median $\mathrm{pH}$ at Lake Tapps Diversion at Dieringer (Tailrace), Washington, May-December 2010 33

Figure 14. Boxplots showing water temperature measured in the epilimnion and hypolimnion at Lake Tapps study sites, Washington, July-December 2010

Figure 15. Boxplots showing dissolved oxygen concentrations measured in the epilimnion and hypolimnion at Lake Tapps study sites, Washington, July-December 2010 .

Figure 16. Boxplots showing $\mathrm{pH}$ measured in the epilimnion and hypolimnion at Lake Tapps study sites, Washington, July-December 2010

Figure 17. Boxplots showing specific conductance measured in the epilimnion and hypolimnion at Lake Tapps study sites, Washington, July-December 2010

Figure 18. Boxplots showing total suspended solids measured in the epilimnion and hypolimnion at Lake Tapps study sites, Washington, July-December 2010

Figure 19. Boxplots showing total phosphorus and total nitrogen measured in unfiltered water samples from the epilimnion and hypolimnion at Lake Tapps study sites, Washington, July-December 2010

Figure 20. Graphs showing Secchi disk transparency depths measured at Lake Tapps study sites, Washington, July-December 2010

Figure 21. Profiles of water temperature and dissolved oxygen concentrations with depth at the Deep site on Lake Tapps, Washington, July-December 2010

Figure 22. Graph showing total suspended solids concentrations by sample date for Lake Tapps study sites, Washington, July-December 2010

Figure 24. Graph showing fecal-coliform bacteria concentrations by sample date for Lake Tapps study sites, Washington, July-December 2010

Figure 23. Graph showing orthophosphate phosphorus concentrations by sample date for Lake Tapps study sites, Washington, July-December 2010

Figure 25. Graph showing nitrite-plus-nitrate nitrogen concentrations by sample date for Lake Tapps study sites, Washington, July-December 2010

Figure 26. Graph showing chlorophyll a concentrations by sample date for Lake Tapps study sites, Washington, July-December 2010.

Figure 27. Boxplots showing total-phosphorus and total-nitrogen concentrations in unfiltered water samples from the epilimnion and hypolimnion by month and by season, Lake Tapps, Washington, June-December 2010 


\section{Tables}

Table 1. Description of study sites on the White River, White River Canal, and Lake Tapps Diversion, Washington, where water-quality and discharge data were collected by the U.S. Geological Survey, May-December $2010 \quad \ldots \ldots \ldots \ldots \ldots \ldots . . \ldots$

Table 2. Description of Lake Tapps study sites, Washington, July-December 2010 ........ 10

Table 3. Types and numbers of quality control samples collected at Lake Tapps, White River (Headworks), White River Canal (Inflow), and Lake Tapps Diversion (Tailrace) sites, Washington, July-December 2010

Table 4. Summary of analytical results for (A) field-blank samples and corresponding environmental water samples and (B) relative percent difference between pairs of samples collected from White River (Headworks), White River Canal (Inflow), and Lake Tapps Diversion (Tailrace) sites, Washington, July-December 2010

Table 5. Constituent concentrations in field-blank samples with detections at or greater than laboratory method detection or reporting levels, and concentrations in corresponding water samples from Lake Tapps, Washington, July-December 2010

Table 6. Summary of relative percent difference among pairs of samples collected from Lake Tapps sites, Washington, July-December 2010

Table 7. Wastewater indicator compounds of analytical Schedule 1433 with low recoveries of a fortified matrix spike solution in sample water from the Lake Outlet site on Lake Tapps, Washington, September 22, 2010

Table 8. Summary of Washington State freshwater aquatic life and recreation designated uses and criteria .

Table 9. Summary statistics of water-quality properties and concentrations of nutrients, total suspended solids, and fecal-coliform bacteria for the study sites on the White River (Headworks), White River Canal (Inflow), and Lake Tapps Diversion (Tailrace), Washington, July-December 2010.

Table 10. Fecal-coliform bacteria in samples from Lake Tapps Diversion at Dieringer (Tailrace), Washington, July-December 2010

Table 11. Summary statistics of water-quality properties and concentrations of nutrients, total suspended solids, fecal-coliform bacteria, and chlorophyll a for nine Lake Tapps study sites, Washington, July-December 2010

Table 12. Lake trophic states and classification ranges for trophic state index, with thresholds for Secchi-disk transparency depths and concentrations of chlorophyll a and total phosphorus (unfiltered water)

Table 13. Summer trophic state indexes for Lake Tapps, Washington, using data collected at nine study sites, July-September 2010

Table 14. Average summer Secchi-disk transparency depths and concentrations of chlorophyll $a$, total nitrogen, and total phosphorus in unfiltered water from the epilimnion, and ratios of total nitrogen to total phosphorus at Lake Tapps study sites, Washington, July-September 2010

Table 15. Organic compounds detected in water samples collected at Allan Yorke, Snag Island (map No. L5), and Lake Outlet (map No. L8) sites on Lake Tapps, Washington, September 21-22, 2010 


\title{
Conversion Factors, Datums, and Abbreviations and Acronyms
}

\author{
Conversion Factors
}

Inch/Pound to SI

\begin{tabular}{|c|c|c|}
\hline Multiply & By & To obtain \\
\hline \multicolumn{3}{|c|}{ Length } \\
\hline inch (in) & 2.54 & centimeter $(\mathrm{cm})$ \\
\hline foot (ft) & 0.3048 & meter $(\mathrm{m})$ \\
\hline mile (mi) & 1.609 & kilometer (km) \\
\hline \multicolumn{3}{|c|}{ Area } \\
\hline square mile $\left(\mathrm{mi}^{2}\right)$ & 259.0 & hectare (ha) \\
\hline \multicolumn{3}{|c|}{ Volume } \\
\hline acre-foot (acre-ft) & 1,233 & cubic meter $\left(\mathrm{m}^{3}\right)$ \\
\hline \multicolumn{3}{|c|}{ Flow rate } \\
\hline foot per second (ft/s) & 0.3048 & meter per second $(\mathrm{m} / \mathrm{s})$ \\
\hline cubic foot per second $\left(\mathrm{ft}^{3} / \mathrm{s}\right)$ & 0.02832 & cubic meter per second $\left(\mathrm{m}^{3} / \mathrm{s}\right)$ \\
\hline
\end{tabular}

SI to Inch/Pound

\begin{tabular}{lcl}
\hline & Multiply & \multicolumn{1}{c}{ To obtain } \\
\hline meter $(\mathrm{m})$ & Length & \\
\hline & 3.281 & foot (ft) \\
\hline milliliter $(\mathrm{mL})$ & Volume & \\
liter (L) & 0.034 & $\begin{array}{l}\text { ounce, fluid (fl. oz) } \\
\text { gallon (gal) }\end{array}$ \\
\hline
\end{tabular}

Temperature in degrees Celsius $\left({ }^{\circ} \mathrm{C}\right)$ may be converted to degrees Fahrenheit $\left({ }^{\circ} \mathrm{F}\right)$ as follows:

$$
{ }^{\circ} \mathrm{F}=\left(1.8 x^{\circ} \mathrm{C}\right)+32
$$

Temperature in degrees Fahrenheit $\left({ }^{\circ} \mathrm{F}\right)$ may be converted to degrees Celsius $\left({ }^{\circ} \mathrm{C}\right)$ as follows:

$$
{ }^{\circ} \mathrm{C}=\left({ }^{\circ} \mathrm{F}-32\right) / 1.8
$$

Specific conductance is given in microsiemens per centimeter at 25 degrees Celsius $(\mu \mathrm{S} / \mathrm{cm}$ at $\left.25^{\circ} \mathrm{C}\right)$.

Concentrations of chemical constituents in water are given either in milligrams per liter (mg/L) or micrograms per liter $(\mu \mathrm{g} / \mathrm{L})$.

This report contains Chemical Abstract Service (CAS) Registry Numbers ${ }^{\circledR}$, which is a Registered Trademark of the American Chemical Society. CAS recommends the verification of the CASRNs through CAS Client Services ${ }^{S M}$. 


\title{
Conversion Factors, Datums, and Abbreviations and Acronyms-Continued
}

\author{
Datums
}

Vertical coordinate information is referenced to the National Geodetic Vertical Datum of 1929 (NGVD 29).

Horizontal coordinate information is referenced to the North American Datum of 1927 (NAD 27) or to the North American Datum of 1983 (NAD 83).

Abbreviations and Acronyms

\begin{tabular}{ll}
\multicolumn{1}{c}{ Abbreviation or } & \multicolumn{1}{c}{ Acronym } \\
\hline CFU & Definition \\
CTD & colony-forming units \\
DEET & conductivity-temperature-depth \\
DCP/EDL & N,N-diethyl-meta-toluamide \\
FSU & data collection platform and electronic data logger \\
FNU & Field Services Unit \\
GC/MS & formazin nephelometric turbidity units \\
HPLC/MS & gas chromatography/mass spectrometry \\
& high-performance liquid chromatography/mass \\
NIST & spectrometry \\
NWIS & National Institute of Standards and Technology \\
NWOL & Natiional Water Information System \\
NTU & USGS National Water Quality Laboratory \\
NTRU & nephelometric turbidity units \\
PAR & nephelometric turbidity ratio units \\
ppb & photosynthetically active radiation \\
OC & parts per billion \\
RM & quality control \\
TSI & river mile \\
TSS & trophic state index \\
USGS & total suspended solids \\
WAWSC & U.S. Geological Survey \\
\hline
\end{tabular}




\title{
Quality of Water in the White River and Lake Tapps, Pierce County, Washington, May-December 2010
}

\author{
By S.S. Embrey, R.J. Wagner, R.L. Huffman, A.M. Vanderpool-Kimura, and J.R. Foreman
}

\section{Abstract}

The White River and Lake Tapps are part of a hydropower system completed in 1911-12. The system begins with a diversion dam on the White River that routes a portion of White River water into the southeastern end of Lake Tapps, which functioned as a storage reservoir for power generation. The stored water passed through the hydroelectric facilities at the northwestern end of the lake and returned to the White River through the powerhouse tailrace. Power generation ceased in January 2004, which altered the hydrology of the system by reducing volumes of water diverted out of the river, stored, and released through the powerhouse. This study conducted from May to December 2010 created a set of baseline data collected under a new flow regime for selected reaches of the White River, the White River Canal (Inflow), Lake Tapps Diversion (Tailrace) at the powerhouse, and Lake Tapps.

Three sites, one on the White River at Headworks, one on the White River at R Street, and one on the Tailrace, were equipped for continuous recording of water-quality data, and three sites (Headworks, White River Canal Inflow, and Tailrace) were sampled for discrete water-quality data. Nine lake sites were measured for physical and water-quality properties and samples were collected for analyses of nutrients, suspended solids, and fecal-coliform bacteria concentrations. Samples from the lake also were analyzed for concentrations of chlorophyll $a$ and organic chemicals.

Discrete samples indicated that water from the White River, White River Canal Inflow, and Tailrace sites generally was turbid, warm, chemically dilute, and well-oxygenated. Exceptions occurred at the sites when flow to the White River Canal was suspended or when little or no flow was released from the lake into the Tailrace. The quality of physical properties and concentrations in water measured continuously at the three sites generally was good and met the freshwater criteria designated by Washington State Department of Ecology for recreational and aquatic-life uses, with several exceptions. The 7-day average of daily maximum temperatures (7-DADMax) was greater than the freshwater aquatic life criterion of 16 degrees Celsius $\left({ }^{\circ} \mathrm{C}\right)$ for core summer salmonid habitat on 6 days at the Headworks site and 37 days at the R-Street site during the study. The 7-DADMax temperatures were greater than the $13^{\circ} \mathrm{C}$ criterion for spawning, rearing, and incubation on 6 days at the Headworks site and 20 days at the R-Street site. The freshwater aquatic life criterion for dissolved oxygen of 9.5 milligrams per liter $(\mathrm{mg} / \mathrm{L})$ for core summer salmonid habitat was not met at the Headworks and R-Street sites for periods during July and August 2010. Exceptions also occurred at the Headworks site for measurements of $\mathrm{pH}$, which were greater than the aquatic life upper limit of $8.5 \mathrm{pH}$ units during July 2010. Aquatic life $\mathrm{pH}$ criteria were not met at the Tailrace site during June, July, and August 2010, when $\mathrm{pH}$ was greater than $8.5 \mathrm{pH}$ units, and during August 2010 when $\mathrm{pH}$ decreased to less than $6.5 \mathrm{pH}$ units.

Lake Tapps water near the surface was relatively clear, warm, and well oxygenated. The clearest water of the nine lake sites was at the Deep site with a median Secchi disk transparency measurement of 6.05 m (meters), which represents a two- to six-fold increase over historical measurements of transparency at this location. Median water temperatures were $18.2-18.9^{\circ} \mathrm{C}$ and maximums were from 22.9-25. $0^{\circ} \mathrm{C}$. Median dissolved oxygen concentrations were greater than $8.42 \mathrm{mg} / \mathrm{L}$ and minimums generally were not lower than $7.4 \mathrm{mg} / \mathrm{L}$.

By early July 2010, weak thermal stratification developed at most lake sites into at least a warm surface layer overlying a small thermocline. A well-defined hypolimnion developed below the thermocline only at the Deep site. With the development of thermal stratification, hypolimnion water became anoxic at several sites (Deep, Tapps Island, Snag Island, and Lake Outlet). By late September 2010, an anoxic layer about $15 \mathrm{~m}$ thick had formed in the hypolimnion of the Deep site. Mixing during autumn overturn in late November re-oxygenated the water column of all the sites with about 10-12 mg/L of dissolved oxygen. 
On the basis of $\mathrm{pH}$ and specific conductance measurements, Lake Tapps water is $\mathrm{pH}$ neutral and chemically dilute. Median $\mathrm{pH}$ values for water in the epilimnion and the hypolimnion ranged from 6.84 to $7.64 \mathrm{pH}$ units and maximums did not exceed $7.8 \mathrm{pH}$ units at any site. Median specific conductance was typically less than 70 microsiemens per centimeter at $25^{\circ} \mathrm{C}$ for the epilimnion and the hypolimnion.

Concentrations of nutrients and chlorophyll $a$ in Lake Tapps were low. At most of the sites and in most of the samples from the epilimnion, total phosphorus concentrations were less than the Washington State Department of Ecology phosphorus criterion of $0.01 \mathrm{mg} / \mathrm{L}$ for maintaining oligotrophic conditions. Median concentrations of total nitrogen (unfiltered water) ranged from about $0.14 \mathrm{mg} / \mathrm{L}$ (Deep, Tapps Island, and Dike 2B sites) to about $0.18 \mathrm{mg} / \mathrm{L}$ (Allan Yorke and Lake Inlet sites). Chlorophyll $a$ concentrations were low with median concentrations of 2.16 micrograms per liter (mg/L) or less. The majority of chlorophyll $a$ concentrations were well below the Oregon Department of Environmental Quality action level of $10 \mathrm{mg} / \mathrm{L}$.

Using the Carlson Trophic-Status Index and average measures of transparency, chlorophyll $a$, and total phosphorus data from this study, Lake Tapps generally fits within the oligotrophic classification, but with a few exceptions. At Allan Yorke, Lake Inlet, and Southeast Arm sites, the chlorophyll $a$ and total phosphorus indexes of nearly 40 approach the upper limit of oligotrophic conditions. In addition, average concentrations of total phosphorus at Lake Inlet and Southeast Arm are at Nürnberg's (1996) threshold concentration of $0.01 \mathrm{mg} / \mathrm{L}$, which suggests a slight tendency towards mesotrophic conditions at these two sites during summer July-September.

On the basis of epilimnetic nitrogen to phosphorus concentration ratios of greater than 17, Lake Tapps primary production is phosphorus limited at all but two study sites. At the Lake Inlet and Southeast Arm sites, ratios of 15 and 16, respectively, for the summer period suggest either nitrogen or phosphorus (or both) may limit algal growth.

Water samples collected at the Allan Yorke, Snag Island, and Lake Outlet study sites were screened for the presence of more than 250 organic chemicals. A total of 14 compounds were detected in trace amounts (or determined to be present) at one or more of the 3 sites. The Allan Yorke site had 9 detections, the Snag Island site had 10 detections, and the Lake Outlet site had 5 detections of compounds mostly belonging to the group of wastewater indicator chemicals. Compounds detected (or with verified presence) at all three sites included the herbicide 2,4-D, the insecticide and mosquito repellant DEET, the herbicide fluridone used for Eurasian watermilfoil eradication, and the herbicide prometon. The largest concentrations of these compounds were in samples from the Allan Yorke site; the lowest concentrations were from the Lake Outlet site.

\section{Introduction}

The completion in 1911-12 of a hydroelectric power-generation project in the White River basin (a subbasin of the Puyallup River basin) of Washington (fig. 1) resulted in hydrologic changes to the river including the formation of Lake Tapps, an off-channel reservoir. A diversion dam constructed on the White River routes a portion of water from the White River into the White River Canal, which delivers the water into Lake Tapps where it was stored for power generation. Dike construction and filling of the reservoir inundated four existing natural lakes and combined them into present-day Lake Tapps (Washington State Department of Ecology, 2010a). Stored water passes through the hydroelectric facilities at the northwestern end of Lake Tapps and returns to the White River through the powerhouse Tailrace at Dieringer. Typical operation of the system involved lowering the lake elevation during autumn and winter, and filling the lake to full elevation in early spring.

Puget Sound Energy ceased generating hydroelectric power in January 2004, which again changed the hydrology of the White River system. Water diversions from the White River continued, but at reduced volumes, for the purpose of maintaining water levels in Lake Tapps. During water years 1982-2003 when hydroelectric power was produced, water diverted from the White River into the White River Canal averaged $890 \mathrm{ft}^{3} / \mathrm{s}$ (fig. 2) and peaked at 2,340 ft $3 / \mathrm{s}$ on December 17, 2001 (U.S. Geological Survey, 2011a, site 12099000). For the same period, an average of $892 \mathrm{ft}^{3} / \mathrm{s}$ was returned to the river through the powerhouse at Dieringer (U.S. Geological Survey, 2011a, site 12101100) . Because the stream-gaging equipment on the White River Canal was not designed for the regularly occurring low discharges after 


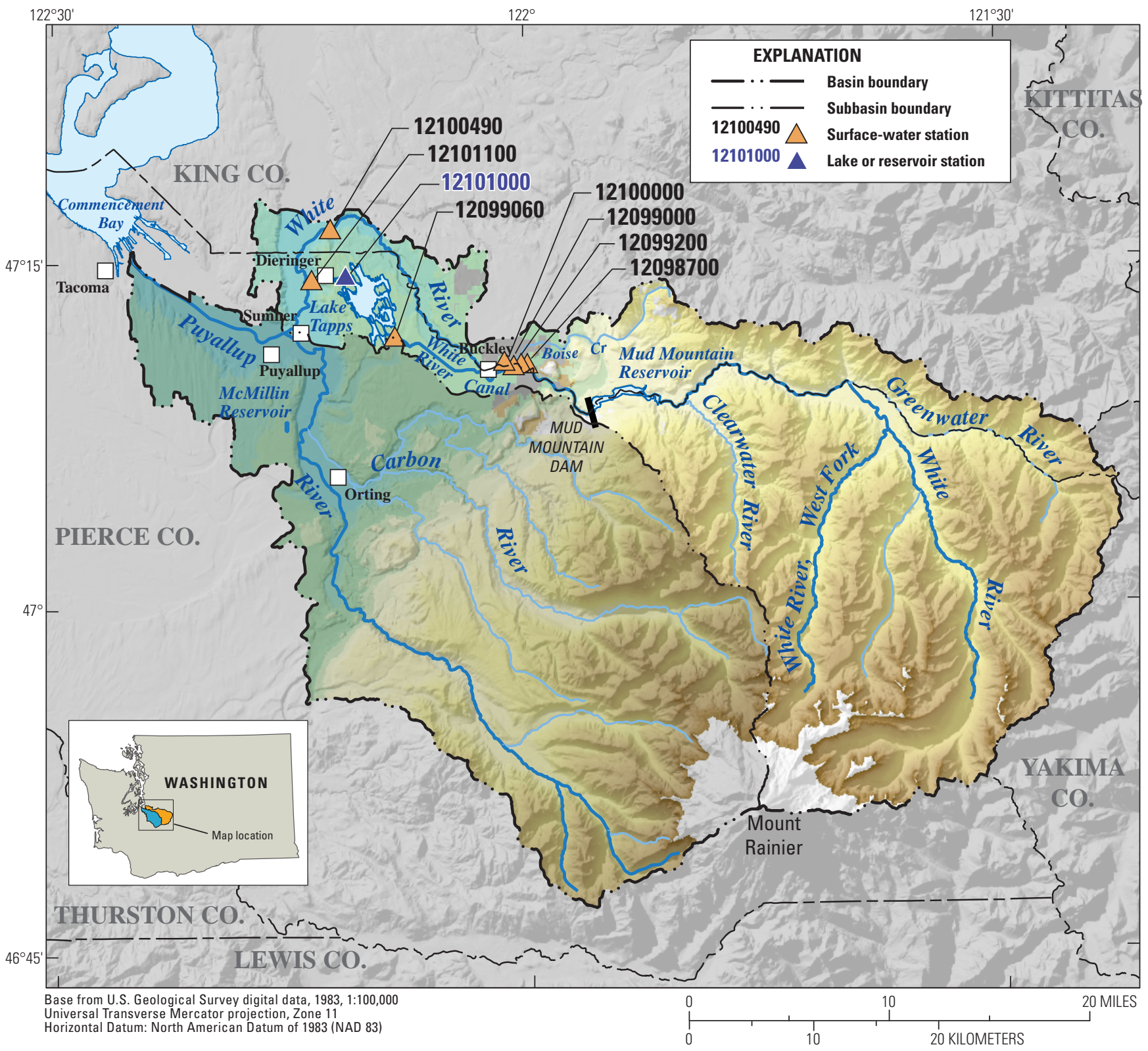

Figure 1. U.S. Geological Survey surface-water and lake-elevation gaging stations in the White River basin, Pierce County, Washington. 


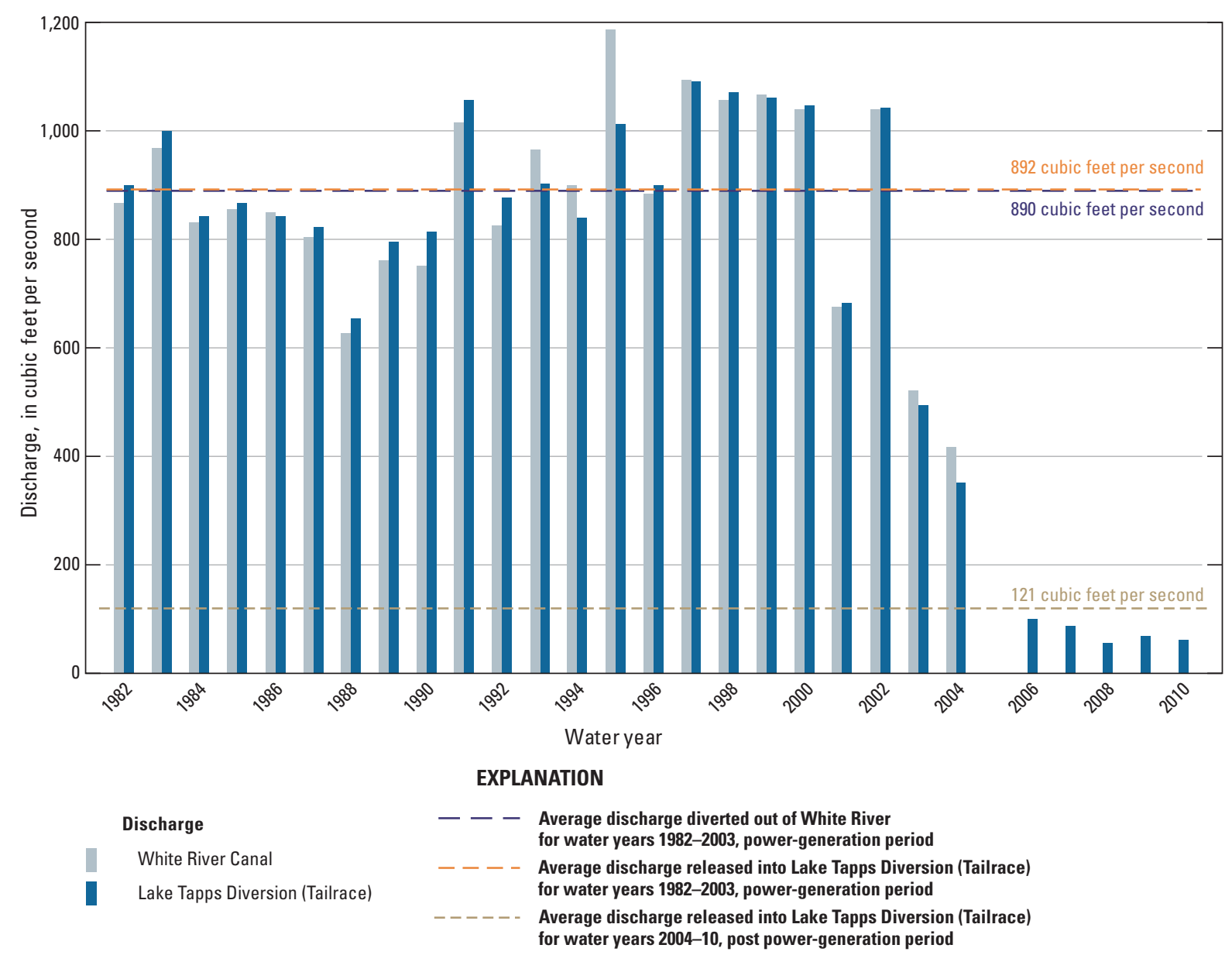

Figure 2. Average discharge at White River Canal (Headworks) and Lake Tapps Diversion at Dieringer (Tailrace), Washington, water years 1982-2010.

January 2004, discharge calculations were discontinued. However, water discharged into the Tailrace at Dieringer provides reasonable approximations of discharge in the White River Canal. During the post power-generation period from 2004 to 2010, discharge in the Tailrace averaged $121 \mathrm{ft}^{3} / \mathrm{s}$ and ranged from 56 to $350 \mathrm{ft}^{3} / \mathrm{s}$ (U.S. Geological Survey, 2011a, site 12101100). Using the assumption that lake outflow is approximately equal to lake inflow, water diverted from the river was reduced from about $890 \mathrm{ft}^{3} / \mathrm{s}$ during the power-generation period to about $120 \mathrm{ft}^{3} / \mathrm{s}$ during post power-generation period. With reduced water diversions, average flows in the river downstream of the diversion dam increased from $579 \mathrm{ft}^{3} / \mathrm{s}$ during the power-generation period (U.S. Geological Survey, 2011a, site 12100000) to $1,270 \mathrm{ft}^{3} / \mathrm{s}$ during the post power-generation period (U.S. Geological Survey, 2011a, site 12099200). The White River Canal inflow to Lake Tapps was further modified in 2007 with the completion of a backflow prevention structure on the Canal downstream of Printz Basin (fig. 3), which now limits the maximum flow into Lake Tapps to about $1,000 \mathrm{ft}^{3} / \mathrm{s}$ (Washington State Department of Ecology, 2010a). 


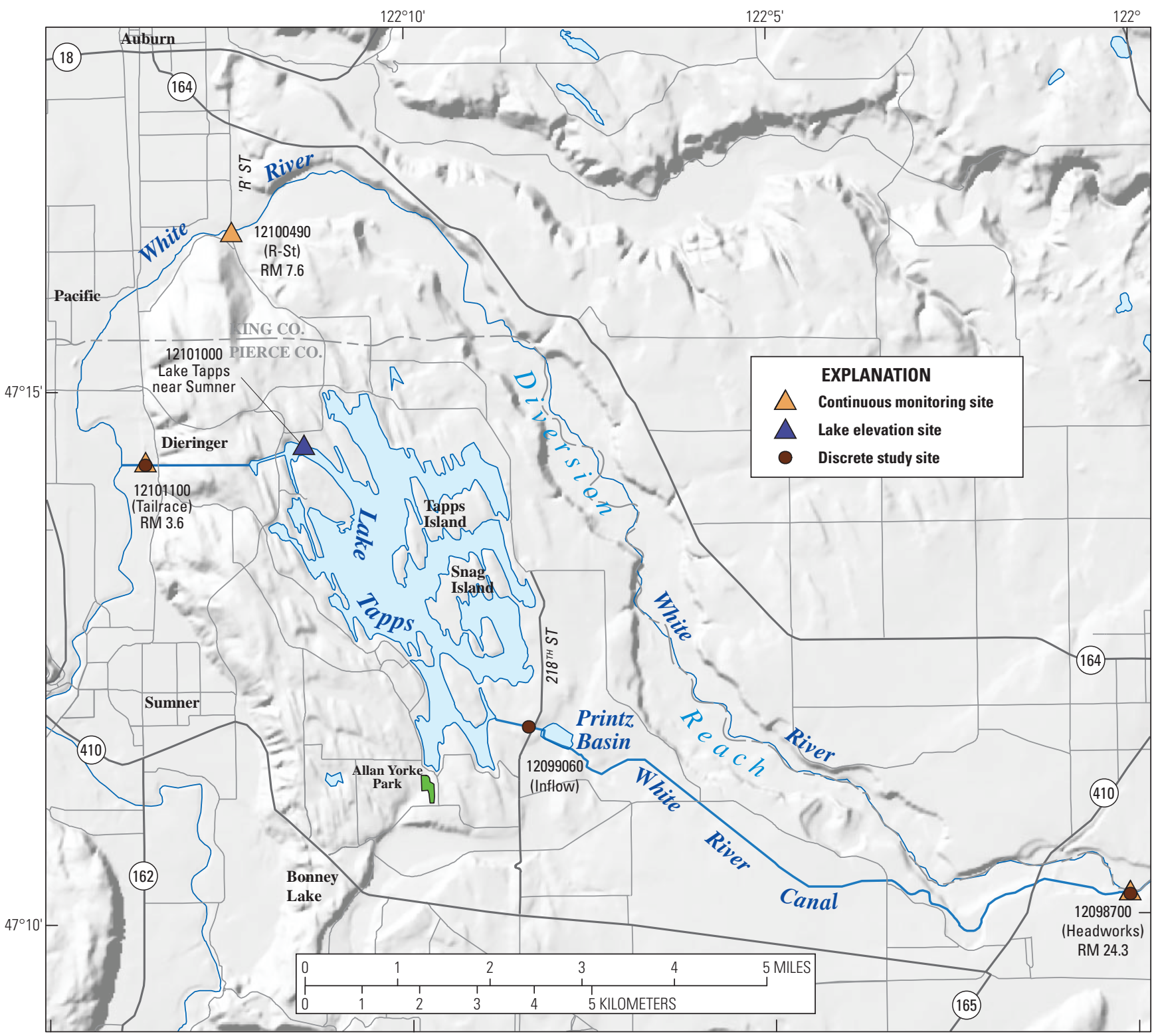

Figure 3. Continuous and discrete water-quality study sites on the White River at Headworks (Headworks site), White River at R Street (R-Street site), White River Canal (Inflow site), and Lake Tapps Diversion (Tailrace site), Washington. 
During 2008-2010, Cascade Water Alliance, with the Muckleshoot Indian Tribe, the Puyallup Tribe of Indians, and Lake Tapps Community (a collective of nine non-profit Lake Tapps entities) entered into a set of agreements to facilitate the development of Lake Tapps as a new source of municipal water supply while protecting and enhancing fishery resources in the White and Puyallup River basins (Washington State Department of Ecology, 2010a). The White River Management Agreement, the 2009 Lake Tapps Community Agreement, and the 2010 Lake Tapps Area Water Resources Agreement include a flow regime specification that provides for minimum flows in the White River; diversions of water from the White River to Lake Tapps Reservoir; operation and maintenance of the Lake Tapps system; continued maintenance of recreational lake levels; and restoration, protection, and enhancement of fishery resources and habitat in the White River basin. The bimonthly schedules for minimum flows and other permit specifications can be found in Washington State Department of Ecology (Ecology) Report of Examination for Permit Number S2-29920(A) (Washington State Department of Ecology, 2010b). The agreements also provide for development and implementation of a cooperative monitoring program to assess water quality in the White River and in Lake Tapps under a new flow regime.

In December 2009, Cascade Water Alliance became the new owners and managers of Lake Tapps Reservoir and the related Lake Tapps-White River hydroelectric project facilities (Washington State Department of Ecology, 2010a). In September 2010, Ecology granted Cascade Water Alliance a set of municipal water rights for new appropriations and the transfer of an existing right (Washington State Department of Ecology, 2010a).

Ecology conducted a study of Lake Tapps and the White River from July 2004 to June 2005 to document water-quality conditions soon after power generation had ceased and when flow through the lake was reduced (Hallock, 2006). Hallock (2006) reported the lake to be oligotrophic but with some indication of mesotrophy based on concentrations of chlorophyll $a$ and determined phosphorus to be the limiting nutrient for primary production. Concentrations of total phosphorus at the lake outlet site were less than concentrations at the lake inlet site indicating the lake functions as a net sink for phosphorus (Hallock, 2006). Pierce County Public Works and Utilities and the Muckelshoot Indian Tribe also collected intermittent data during this 2004-05 time frame (Pierce County Public Works and Utilities, 2007). In summarizing these 2004-05 data, Welch shows Lake Tapps (represented by the main western basin and deepest location) to be oligotrophic and phosphorus limited (Eugene Welch, University of Washington, professor emeritus, written commun., March 2011). With reduced diversions from the White River and inflows to the lake, Welch also noted transparency depths increased from about $1 \mathrm{~m}$ in 1981 to $3.6 \mathrm{~m}$ in 2005 and related these greater transparencies to longer water retention times in the lake when inflows into the lake were reduced. The longer retention time allows for more settling of non-algal particles, including particles with adsorbed phosphorus, resulting in clearer water and lower total phosphorus concentration. Because the lake productivity is limited by phosphorus, Welch concluded that the clearer water should not result in larger algae populations, but it might favor greater establishment and growth of macrophytes, particularly Eurasian watermilfoil (Eugene Welch, written commun., March 2011). In 2006 and 2007, another set of waterquality data was collected by the Muckelshoot Indian Tribe (Nancy Rapin, Muckelshoot Indian Tribe, written commun., March 2011). Earlier studies of the White River-Lake Tapps system from about 1974 through 2002 (Bortleson and others, 1976; Sumioka and Dion, 1985; Smith and others, 2000; Bell-McKinnon, 2002; Ebbert, 2002, 2003) were conducted when lake water levels, White River diversions, and releases back into the White River were managed by Puget Sound Energy for power production.

This study was conducted in cooperation with Cascade Water Alliance. The water-quality data from this study establishes a baseline set of data collected under the flow regime in place from May to December 2010 for selected reaches of the White River, White River Canal, Lake Tapps Diversion, and Lake Tapps.

\section{Purpose and Scope}

This report presents and summarizes water-quality data collected by the U.S. Geological Survey (USGS) from May to December 2010 from a total of 13 sites - two on the White River (Headworks, R-Street), one on the White River Canal (Inflow), one on the Lake Tapps Diversion (Tailrace), and from nine sites on Lake Tapps. Discrete water samples were collected bimonthly in July and August at the White River at Headworks and White River Canal sites. The Tailrace site was sampled bi-monthly in July and August and monthly in November and December. Discrete water samples were not collected at the R-Street site; only continuous, 15-minute water-quality data were collected. The nine lake sites were sampled bimonthly from July through October and monthly in November and December. 
The water-quality data collected for this study consist of concentrations of nutrients, suspended solids, fecal-coliform bacteria, and turbidity in discrete water samples; and 15-minute values of water temperature, specific conductance, dissolved oxygen concentration, $\mathrm{pH}$, and turbidity continuously measured by in-situ water-quality sondes. Water-quality data collected from the lake sites consist of concentrations of nutrients, suspended solids, fecal-coliform bacteria, chlorophyll $a$, and turbidity, and vertical profiles of various water-quality and physical properties through the lake water column. In addition, a one-time sampling of water from three of the lake sites was analyzed for suites of organic chemicals. This report focuses on the water-quality data collected under the conditions of the May-December 2010 flow regime in the White River, White River Canal, Lake Tapps Diversion, and through Lake Tapps.

\section{Description of Study Area}

The White River, which is located in Pierce County, Washington, originates from glaciers on Mount Rainier. From Mount Rainier, the river flows to its confluence with the Puyallup River, which subsequently empties into Commencement Bay near the city of Tacoma, Washington (fig. 1). Because of its glacial origins, the White River transports fine glacial till material that gives the river a whitish color during summer. Lake Tapps also is located in Pierce County about $18 \mathrm{mi}$ east of Tacoma. The City of Bonney Lake lies along the southern end of the lake (ig. 3 ).

Downstream of the Mud Mountain Dam, the White River flows generally northwest to river mile (RM) 24.3 where a diversion dam at the hydropower headworks diverts water out of the White River and into the White River Canal. Downstream of the diversion dam, the White River continues to flow northwest to the city of Auburn. Near Auburn, the river turns generally southwest then flows south through the town of Pacific, past the powerhouse at Dieringer, and joins the Puyallup River at the city of Sumner (fig. 3). The reach of the river between the diversion dam at RM 24.3 and RM 3.6 is referred to as the Diversion Reach. The river is about $75 \mathrm{mi}$ long with a drainage area of $494 \mathrm{mi}^{2}$ (Washington State Department of Ecology, 2010a).
Six anadromous salmonid species use the White River basin for spawning, incubation, rearing, and migration. These species include Chinook salmon (Oncorhynchus tshawytscha), coho salmon (O. kisutch), chum salmon (O. keta), pink salmon (O. gorbuscha), steelhead (O. mykiss), and bull trout (Salvelinus confluentus) (National Marine Fisheries Service, 1999, 2007; U.S. Fish and Wildlife Service, 1999). The National Marine Fisheries Services (1999, 2007) listed Puget Sound Chinook and steelhead as threatened under the Endangered Species Act in 1999 and 2007, respectively. The U.S. Fish and Wildlife Service (1999) listed CoastalPuget Sound bull trout as threatened under the Endangered Species Act in 1999. Favorable water-quality conditions for fish occasionally have not been met in the reach of the White River downstream of the diversion dam. Some segments in this reach have been included on Ecology's water quality assessment and 303(d) list for $\mathrm{pH}$, temperature, or fecal-coliform bacteria, and at RM 0.4, the White River is on the 303(d) list for dissolved oxygen concentrations (Washington State Department of Ecology, 2009).

The river water that is routed into the White River Canal at the Headworks diversion dam flows through $8 \mathrm{mi}$ of canals, flumes, fish screens, five settling basins, and pipes (Washington State Department of Ecology, 2010a) into Lake Tapps at the southeastern end (fig. 3). The lake is about $4.5 \mathrm{mi}$ long and $2.5 \mathrm{mi}$ wide with an area of 2,740 acres (Washington State Department of Ecology, 2010a). The lake has a maximum volume of 67,000 acre-ft, a mean depth of about $25 \mathrm{ft}$ and a maximum depth of about $90 \mathrm{ft}$ (Sumioka and Dion, 1985). The normal water-surface elevation of the lake at full pool is between 541.0 and $542.5 \mathrm{ft}$ with an active storage capacity of 46,700 acre-ft (Washington State Department of Ecology, 2010a). The area around Lake Tapps was originally sparsely populated, but the lake shoreline is now developed with residential homes. There are several public and private parks and boat launch facilities on the lake (fig. 3), which are heavily used for recreation by residents and visitors. At the northwestern end of Lake Tapps, the stored water passes through the hydroelectric facilities and returns to the White River at RM 3.6 through the $1 / 2$-mile long Lake Tapps Diversion at Dieringer (Reese, 2010).

For this report, names of stream gaging and sampling sites have been abbreviated or simplified. USGS station identification numbers and details of site locations are shown in table 1. 
Table 1. Description of study sites on the White River, White River Canal, and Lake Tapps Diversion, Washington, where water-quality and discharge data were collected by the U.S. Geological Survey, May-December 2010.

[Type of data: Continuous, water-quality data electronically monitored and recorded at 15 -minute intervals. Discrete, water-quality data measured by watersample collection and analysis at a point in time. -, no data or not applicable]

\begin{tabular}{|c|c|c|c|c|c|c|c|}
\hline $\begin{array}{c}\text { USGS } \\
\text { station No. }\end{array}$ & USGS station name & Short name & $\begin{array}{c}\text { Latitude } \\
\circ \text { ' " }\end{array}$ & $\begin{array}{c}\text { Longitude } \\
\circ " \text { " }\end{array}$ & $\begin{array}{l}\text { River } \\
\text { mile }\end{array}$ & $\begin{array}{c}\text { Drainage } \\
\text { area }\end{array}$ & Type of data \\
\hline 12098700 & $\begin{array}{l}\text { White River at Headworks, above } \\
\text { Flume, near Buckley }\end{array}$ & Headworks & 471012 & 1220005 & 24.3 & 410 & $\begin{array}{l}\text { Water-quality monitoring } \\
\text { (continuous, discrete) }\end{array}$ \\
\hline 12099000 & White River Canal at Buckley & White River Canal & 471019 & 1220113 & - & - & Discharge \\
\hline 12099060 & $\begin{array}{l}\text { White River Canal above Lake Tapps, } \\
\text { near Buckley }\end{array}$ & Inflow & 471149 & 1220822 & - & - & $\begin{array}{l}\text { Water-quality monitoring } \\
\text { (discrete) }\end{array}$ \\
\hline 12100000 & White River at Buckley & - & 471028 & 1220109 & - & 427 & Discharge \\
\hline 12100490 & White River at R Street, near Auburn & R-Street & 471630 & 1221224 & 7.6 & 474 & $\begin{array}{l}\text { Discharge, water-quality } \\
\text { monitoring (continuous) }\end{array}$ \\
\hline
\end{tabular}

1. The reach of the White River between the diversion dam at RM 23 near Buckley and Lake Tapps Diversion at Dieringer at RM 6 is referred to as Diversion Reach;

2. White River at Headworks above Flume near Buckley is referred to as Headworks;

3. White River at R Street near Auburn is referred to as R-Street;

4. Lake Tapps Diversion at Dieringer is referred to as Tailrace; and

5. White River Canal above Lake Tapps near Buckley is referred to as Inflow.

Discrete water samples for measuring chemical concentrations and physical properties were collected from the Headworks, Tailrace, and Inflow sites. Discrete water samples were not collected at the R-Street site. Stream-gaging stations for measuring stage and discharge also are located at the R-Street and Tailrace sites (table 1). Three sites-Headworks, R-Street, and Tailrace-were equipped for recording measures of water-quality data at 15-minute intervals to provide a nearly continuous record of water quality and capture the seasonal, diurnal, and event-driven fluctuations in water quality (fig. 3).

The nine sampling sites on Lake Tapps were distributed throughout the lake to coincide with or to be near sampling locations of previous investigations and to include a range of physical and nearshore conditions (fig. 4). The Deep site (map No. L1) in the main part of the western basin is the deepest of the nine study sites at about $27 \mathrm{~m}$. The shallowest site of the study at about $3 \mathrm{~m}$ in depth was Southeast Arm (map No. L7) (table 2). 


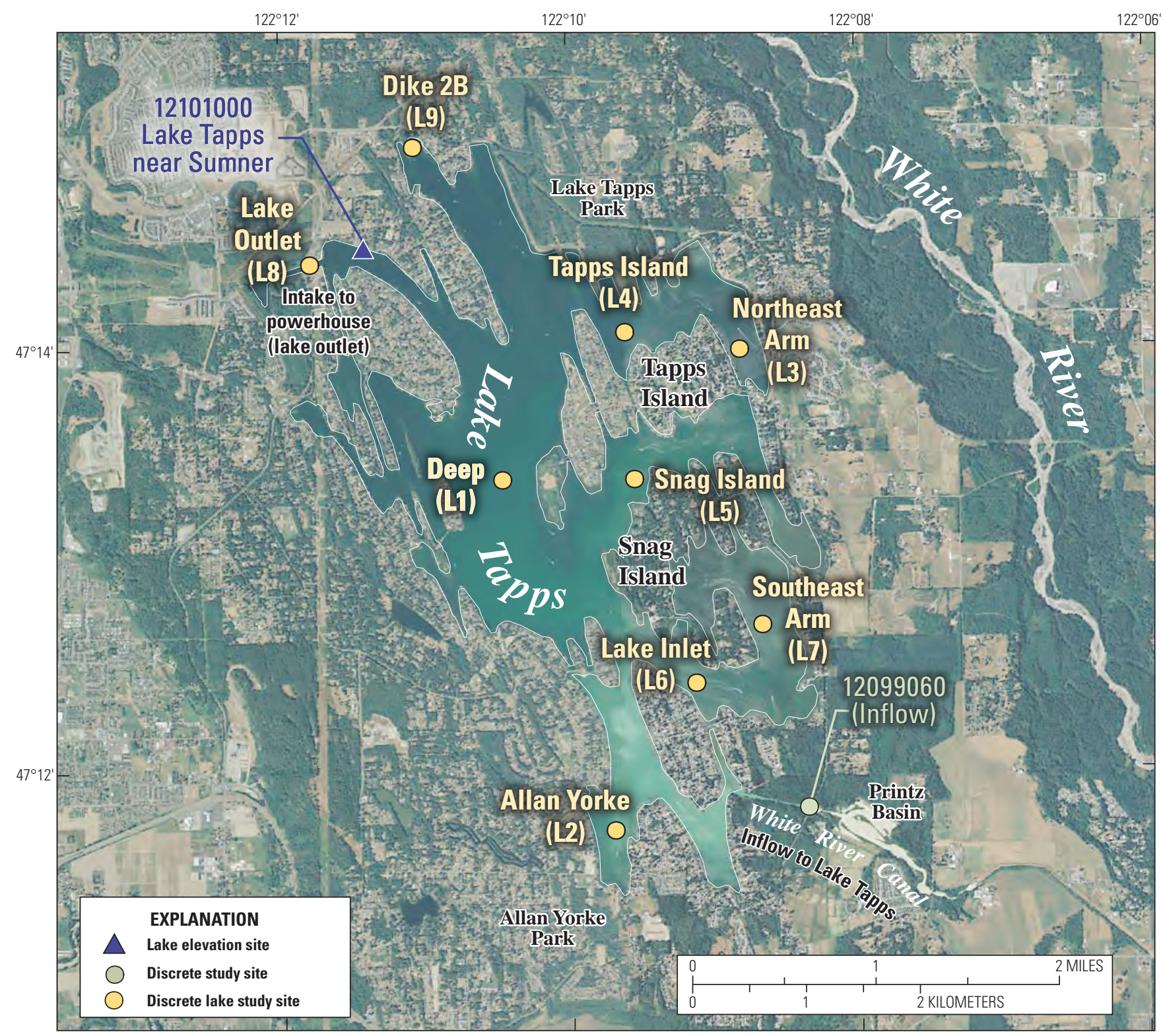

Figure 4. Locations of study sites on Lake Tapps, Washington. 
Table 2. Description of Lake Tapps study sites, Washington, July-December 2010.

[USG S site No: The 01 suffix uniquely identifies data for the epilimnion (E) and the 02 suffix uniquely identifies data for the hypolimnion (H). Latitudes and longitudes: In minutes, degrees, seconds. Comments: CWA, Cascade Water Alliance; Ecology, Washington State Department of Ecology; \#, number. Abbreviation: m, meter]

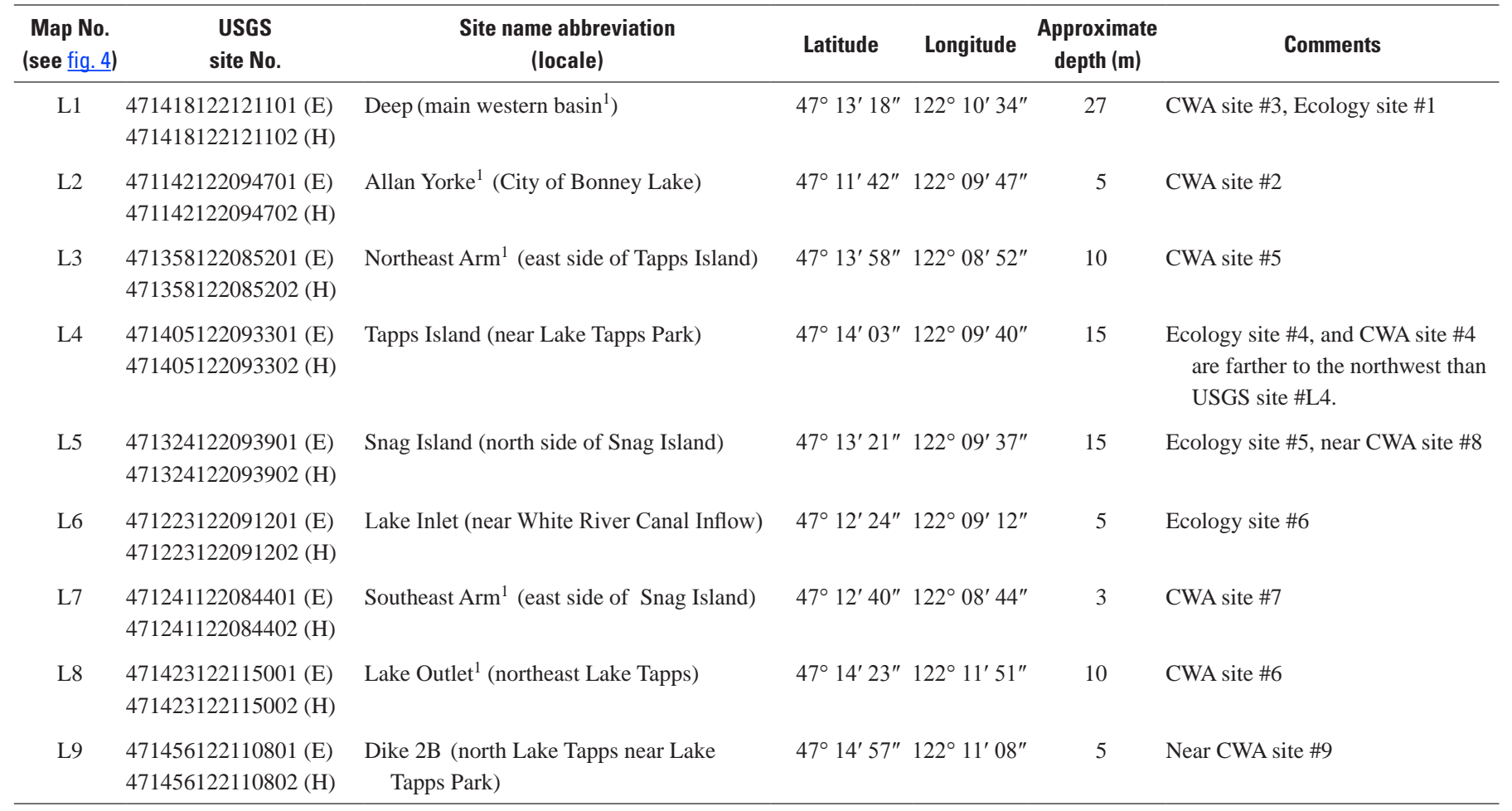

${ }^{1}$ Site or locale names from Michael Gagliardo, Cascade Water Alliance, written commun., June 2010.

\section{Methods and Procedures}

\section{River Continuous Monitors}

Multiparameter water quality sondes, housed in an open-ended 4 in. $\times 12.5 \mathrm{ft}$ PVC pipe perforated with numerous $1 / 2$-in. diameter holes, were installed at three sites and fully operational by late May 2010. The sondes were programmed to collect measurements of physical properties (water temperature, specific conductance, $\mathrm{pH}$, and turbidity) and concentrations of dissolved oxygen in ambient water every 15 minutes. The sondes interfaced with a data collection platform and electronic data logger (DCP/EDL) to transmit data hourly using high-data rate satellite telemetry. All sondes were calibrated prior to deployment, as described by Wagner and others (2006) and Gibs and others (2007), and generally checked for calibration monthly or every 2 months during autumn and winter.

The conductivity sensors were calibrated using a 1-point calibration to a $1,000 \mu \mathrm{S} / \mathrm{cm}$ potassium chloride standard. Linearity response of the sensor was checked monthly, or before and after sensor replacement, by ensuring a zero reading of the dry sensor in air and measuring several specific conductance standards between 0 and $1,000 \mu \mathrm{S} / \mathrm{cm}$ that included the expected range of specific conductance. The $\mathrm{pH}$ sensors were calibrated using a 2-point calibration with temperature adjusted $\mathrm{pH} 7$ and $\mathrm{pH} 10$ buffer solutions. The dissolved oxygen sensors were calibrated in watersaturated air using the percent-saturation method prior to deployment, but subsequent calibrations or calibration checks used air-saturated water at stable temperatures in the USGS Washington Water Science Center (WAWSC) Field Services Unit (FSU) to ensure 100 percent saturation. The turbidity sensors (YSI 6136) were calibrated using a 2- or 3 -point calibration with the first point being zero formazin nephelometric turbidity units (FNU) and followed by a 10 or 1,000 FNU turbidity standard. The sensors were calibrated at the FSU prior to deployment and all calibrations or calibration checks were performed using a dedicated sonde guard and dedicated plastic calibration cups and protected from wind and direct sunlight, as described in YSI Inc. (2010). Calibration and reporting procedures for turbidity also are discussed by Anderson (2005). 
The water temperature sensors do not require calibration, but the sondes were compared at five temperature points (between 0 and $30^{\circ} \mathrm{C}$ ) with a National Institute of Standards and Technology (NIST) traceable thermistor, as described by Wilde (2006) in the month prior to deployment. During site visits, temperature readings of the installed sonde were compared with another sensor that also had been checked annually at five temperature points and 2-point calibration checks at least twice during the year.

\section{Turbidimeter and Vertical Profiling Instruments for River and Lake Measurements}

Prior to use, the HACH 2100P turbidimeters were calibrated with the manufacturer's standards and according to the manufacturer's guidance. Prior to use, the conductivitytemperature-depth (CTD) instrument used for profiling surface-to-bottom water quality conditions at each lake site was sent to the manufacturer (Sea-Bird Electronics, Inc., Bellevue, Washington) for factory calibration and installation of a new $\mathrm{pH}$ sensor. Calibration coefficients in the CTD firmware were updated and the calibration records filed in the WAWSC in Tacoma, Washington. The CTD instrument used during this study was a Sea-Bird SBE 19plus V2 SEACAT equipped with auxiliary sensors that included a SBE 43 dissolved oxygen sensor, a SBE $18 \mathrm{pH}$ sensor, a QSO2300 Biospherical photosynthetically active radiation (PAR) sensor, and a WETLabs ECO-FLU fluorometer and turbidity sensor.

\section{Field-Trip Preparation, Sample-Collection, and Sample-Handling Protocols}

All equipment for sample collection, compositing, filtration, and processing of water for chemical analyses was cleaned in the WAWSC FSU using parts-per-billion (ppb) procedures, as described by Wilde (2004) in the USGS National Field Manual (U.S. Geological Survey, variously dated). In addition, all collection and processing equipment used for fecal-coliform bacteria analyses were autoclaved after cleaning, as described by Myers and others (2007). Autoclave indicator tape was applied to each piece of equipment to identify it as sterile and to distinguish it from other non-sterile equipment. Capsule and disk filters used in the field to filter water samples for chemical analyses were pre-conditioned, and sample bottles for shipping to laboratories rinsed with FSU Type I deionized water treated by reverse osmosis. Petri dishes (plates) of solid medium for culturing fecal-coliform bacteria were prepared 1 day prior to sampling. A sufficient volume of medium was prepared at one time and the plates needed to process all three river and nine lake sites over 2 days were poured and held in the refrigerator for no longer than 72 hours (U.S. Geological Survey, 2011b). Two people collected, processed, and handled water samples at the sampling sites following ppb protocol, as described by U.S. Geological Survey (2006). Samples for chemical analysis requiring filtration or preservation treatment were processed onsite. All samples were stored in the dark and on ice (in ice chests) for transportation back to the FSU where the samples were stored in refrigerators for further processing or for shipping to laboratories the following day. Samples for the enumeration of fecal-coliform bacteria were filtered and incubated in the FSU within 6 hours of collection, as described by Myers and others (2007).

Prior to each field sampling event, the battery life of the CTD instrument was checked, and batteries changed if needed. The conductivity cell was filled with a 0.1 -percent Triton-X-100 solution, using a syringe and clear Tygon ${ }^{\circledR}$ tubing attached to the intake of the CTD instrument. The solution was syringed into the conductivity cell at least 1 hour prior to deployment to thoroughly wet the cell. The $\mathrm{pH}$ sensor was calibrated monthly with three $\mathrm{pH}$ buffer solutions ( $\mathrm{pH} 4$, 7 , and 10) following procedures as described by Sea-Bird Electronics, Inc. (2010).

\section{Post-Field Trip Sample Processing and Handling}

In the FSU following the day of collection, the sample bottles for chemical analyses were packed in waterproof bags in ice chests and shipped on ice by overnight delivery to the USGS National Water Quality Laboratory (NWQL) in Lakewood, Colorado, and to Test America Laboratory in Arvada, Colorado, which is under contract to the NWQL. Samples for turbidity measurements were removed from the refrigerators and allowed to warm to room temperature. After verifying the calibration of the meter, aliquots of sample water were measured using a HACH 2100P portable turbidimeter. As many as five readings were recorded on the site field sheet. The median value was reported in ratio-corrected nephelometric turbidity units (NTRU), as described by Anderson (2005). Sample water for laboratory determinations of chlorophyll $a$ concentration was filtered through glass fiber filters with a $0.7-\mu \mathrm{m}$ effective pore size, sealed in foil and waterproof bags, and frozen. The frozen filters for all nine lake sites collected over a 2-day period were shipped together on dry ice to the NWQL the same week of sample collection. Plates culturing the fecal coliform bacteria were examined after 22-26 hours for colony growth, and the number of colonies was recorded on the site field sheet. 


\section{Post-Field Trip Vertical Profiling Instrument Maintenance and Data Processing}

After deployment, the outside of the CTD instrument was rinsed thoroughly in the FSU with tap water to clean off any debris, silt, or mud. The outer sensors (PAR, fluorometer, and $\mathrm{pH}$ ) were inspected and rinsed thoroughly with tap water followed by deionized water. The $\mathrm{pH}$ sensor was then stored in fresh $\mathrm{pH} 4$ buffer solution saturated with potassium chloride. The conductivity cell and the dissolved oxygen sensor plumbing assembly were cleaned with 0.1 -percent Triton-X-100 solution using a syringe and tubing attached to the CTD sample intake. The solution was agitated through the plumbing several times to flush the entire plumbing assembly; the flushing was followed by several deionized-water rinses. The CTD instrument was then allowed to dry and stored in a clean dry environment until the next deployment.

\section{Processing of Vertical Profiling Instrument Data Files}

The CTD profile data were collected at the maximum resolution of the CTD instrument, four scans of data per second. CTD data files were further processed using Sea-Bird SBE Data Processing ${ }^{\complement}$ software. The primary variables of pressure, temperature, conductivity, dissolved oxygen, and fluorometric values were converted from raw data to engineering values and voltages. After converting the data, the SBE Data Processing software advances temperatures by 0.5 second and dissolved oxygen values by 3 seconds to compensate for transit delays to the pumped sensors and response-time differences. Additional software commands further match response times for temperature, conductivity, and pressure; and remove digital noise from pressure data. The DERIVE command generates variables that are dependent on pressure, temperature, conductivity, or auxiliary sensor data, such as depth, in meters; dissolved oxygen, in milligrams per liter; and specific conductance, in microsiemens per centimeter at 25 degrees Celsius. Data recorded during the up and down casts were then separated and the down-cast data averaged over 0.5-m depths. Data processing details are described in the SBE Data Processing Manual (Sea-Bird Instruments, Inc., 2011).

\section{River, Canal, and Diversion Water Sampling and Onsite Processing}

Samples of water were collected from the White River at a bridge at the Headworks site and from the Inflow site at a bridge on 218th Street E using a DH-95 sampler at 5-10 equidistant vertical locations (multiple vertical and non-isokinetic). The Tailrace site was sampled by wading upstream of the weir using a DH-81 sampler, as described by
Wilde (2006). The samples from multiple vertical locations were composited in a plastic or Teflon ${ }^{\circledR}$ churn splitter, which is used to split the composited water into various subsamples for preservation or further processing, as described by Wilde and others (2004). Sample bottles for analyses requiring unfiltered water were filled first from the churn and bottles for analyses requiring filtered water were then filled using a peristaltic pump and a $0.45-\mu \mathrm{m}$ disposable filter. Field parameters (water temperature, $\mathrm{pH}$, dissolved oxygen, specific conductance, and sometimes turbidity) were measured at the same vertical locations using a multiparameter sonde and median values were reported.

Sondes were calibrated onsite at the beginning of each sample day or in the FSU prior to field work. If sondes were calibrated in the FSU, the buffers and standards were used at room temperature, but if sondes were calibrated onsite, the buffers and standards were submerged in a mesh bag in the stream to equilibrate to the stream temperature. The $\mathrm{pH}$ sensor was calibrated with a 2-point calibration using $\mathrm{pH} 7$ and $\mathrm{pH} 10$ buffers that were within $5^{\circ} \mathrm{C}$ of the stream temperature (when calibrated in the field). The conductivity sensor was calibrated with a $1,000 \mu \mathrm{S} / \mathrm{cm}$ potassium chloride standard, and values of several standards that bracketed the conductance of the sample water were verified. The polarographic dissolved oxygen sensor was calibrated using the water-saturated air calibration method or in an air-saturated water bath at the FSU, whereas the optical dissolved oxygen sensor was calibrated in an air-saturated water bath in the FSU. The barometric pressure and water temperature were used to determine the dissolved oxygen concentration at saturation for calibrating the sensor. All sonde thermistors were checked annually for accuracy against a standard NIST traceable reference thermometer with a five-point temperature check. In addition, all meters are checked at two temperatures, an ice bath and room temperature, at least twice during the year.

\section{Lake Water Sampling and Onsite Processing}

Upon anchoring the boat at the sampling sites, the initial activity was to prepare the CTD profiling instrument for deployment. This involved attaching the instrument to a cable on a reel; removing the syringe duct plumbing, $\mathrm{pH}$ storage container, and protective caps housing the auxiliary sensors; and switching on the power. Using the reel, the CTD instrument was lowered into the water and submerged to the top of the purge plumbing to allow excess air to escape. The instrument was soaked at the water surface for about 1 minute to allow the sample pump to begin operating and flushing the plumbing. The instrument was then lowered through the water column at a rate of about $1 \mathrm{ft} / \mathrm{s}$ and raised at the same rate, if possible, for a complete profile cast (fig. 5). After the cast, the instrument was recovered onboard, turned off, then the protective caps and $\mathrm{pH}$ buffer storage container were placed back onto the appropriate sensors. 

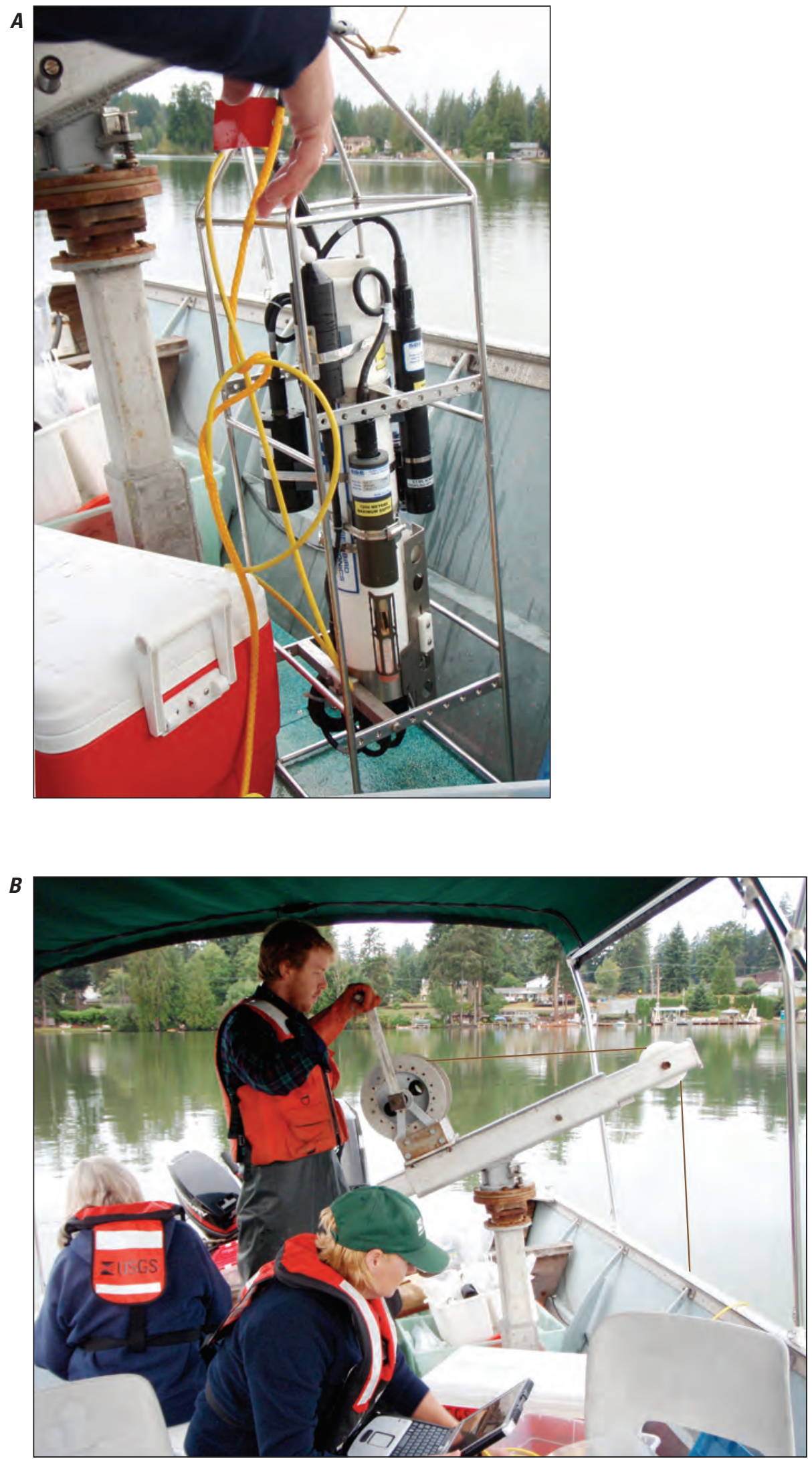

Figure 5. Sea-Bird conductance, temperature, depth (CTD) profiling instrument assembly $(A)$ and deployment while monitoring real-time data output $(B)$. 
The CTD instrument was attached to a laptop computer during the casts in order to observe real-time data showing total water-column depth and associated field parameters of temperature, dissolved oxygen, specific conductance, $\mathrm{pH}$, turbidity, fluorescence, and PAR with depth. The real-time data, particularly the temperature profile that indicated if the water column was thermally stratified, and the total water-column depth determined the sampling strategy for that site on the day of collection. During the casts of the CTD instrument, Secchi disk and air temperature readings were recorded on field sheets with additional notes concerning weather, boat traffic, water conditions, and other observations (appendix A).

If the water column at the lake sampling site was thermally stratified, sample water for chemical analyses typically was collected from four points within the epilimnion and hypolimnion, then composited into separate plastic or Teflon ${ }^{\circledR}$ churn splitters. Water for analyses requiring whole water was split from the churn and then the remaining water was passed through a $0.45-\mu \mathrm{m}$ pore-size disk filter into bottles for analyses requiring filtered water. If the water column was not thermally stratified, point samples were collected from $1 \mathrm{~m}$ below the water surface and from about $0.5 \mathrm{~m}$ to $1 \mathrm{~m}$ above the lake bottom. Thus, discussions of the quality of water in the epilimnion and hypolimnion in this report can refer to data obtained by point or composite-sampling, or by a combination of both methods.

During the first sampling event of July, samples were collected with a 1.7-L Niskin bottle attached to a weighted rope marked in 0.5-m intervals and positioned at one or more specific depths in the water column depending on stratification. If the Niskin bottle was used for non-stratified point samples, the bottle was filled multiple times at the target depth and emptied into a churn splitter until a sufficient volume was obtained to fill all sample bottles for chemical analyses.

Beginning with the second sampling event in July and continuing through the remainder of the study, sample collection was changed from Niskin bottles to a peristaltic pump with Teflon ${ }^{\circledR}$ or polyethylene tubing to allow more thorough cleaning and to easily collect organic samples using Teflon ${ }^{\circledR}$ materials. With the tubing lines attached to the weighted rope, the sampling-line orifice was lowered to specific depths and water pumped to the surface with the peristaltic pump. If the water column was stratified, the sampling-line orifice was lowered to multiple target depths and pumped into a churn splitter. If the water column was not stratified, the sampling-line orifice was lowered to $1 \mathrm{~m}$ below the water surface and to about $0.5-1 \mathrm{~m}$ above the lake bottom and pumped directly as whole water into sample bottles or through a $0.45-\mu \mathrm{m}$ pore-size disk filter into sample bottles.
Water for analysis of fecal-coliform bacteria was collected approximately $0.5 \mathrm{~m}$ below the water surface. An autoclaved sterile DH-81 bottle and cap assembly attached to a DH-81 sampler was lowered to the target depth and allowed to fill.

Samples requiring preservative were acidified with $1 \mathrm{~mL}$ of 4.5-normal sulfuric acid. Lot numbers for the preservative and disk filters were recorded on the site field sheet. Sample bottles were sealed in waterproof bags and stored in ice chests for scheduled mid-day pick up by USGS personnel so that samples could be returned to the FSU and the fecal-coliform bacteria samples processed within 6 hours of collection.

\section{Analytical Methods}

All river and lake samples were analyzed for concentrations of nutrients, total suspended solids, turbidity, and fecal-coliform bacteria. Lake samples also were analyzed for concentrations of chlorophyll $a$, and samples from three lake sites were analyzed for organic chemicals. The NWQL in Lakewood, Colorado, analyzed the samples for nutrients using NWQL Schedule 1865 (appendix B). Filtered samples for the analysis of ammonia were analyzed colorimetrically using a salicylate-hypochlorite method described by Fishman (1993). Filtered samples were analyzed for nitrite-plus-nitrate nitrogen by reducing the nitrate to nitrite with copperized cadmium. The resulting nitrite, plus any originally present in the sample, was determined by automated, continuous flow colorimetry (Fishman, 1993). Filtered samples for the analysis of orthophosphate phosphorus used a phosphomolybdate method, as described by Fishman (1993). Total nitrogen and total phosphorus in filtered and unfiltered samples were determined as nitrate and orthophosphate after conversion to those species by alkaline persulfate digestion (Patton and Kryskalla, 2003). Similarly, filtered and unfiltered samples for the analysis of low-level phosphorus were oxidized to be determined as orthophosphate, as described by U.S. Environmental Protection Agency (1993). In this report, unfiltered phosphorus is referred to as total phosphorus. Nitrate and orthophosphate in the persulfate digests were analyzed with a dual-channel photometric, air-segmented continuous flow analyzer, as described by Patton and Kryskalla (2003).

The Allan Yorke, Snag Island, and Lake Outlet study sites were sampled to screen for the presence of organic chemicals. These sites were chosen for potential effects on water quality from population density and management activities with respect to future water uses. Water samples collected from the sites on September 21 and 22 were filtered through a $0.7-\mu \mathrm{m}$ glass-fiber filter and submitted to NWQL for analyses of wastewater indicator chemicals, pesticides, human-health pharmaceuticals, and the pesticide fluridone (appendix C). Pharmaceutical compounds were analyzed using 
NWQL Schedule 2080; wastewater indicator compounds were analyzed using Schedule 1433; human-health pharmaceuticals were analyzed using NWQL laboratory code 8144 as an add-on to Schedule 1433; pesticide and pesticide degradation products were analyzed using Schedule 2033; and the pesticide fluridone was analyzed by NWQL laboratory code 8072 as an add-on to Schedule 2033. Samples for analysis of wastewater indicator compounds were extracted by vacuum through polystyrene-divinylbenzene cartridges, eluted, and then analyzed by capillary-column gas chromatography/mass spectrometry (GC/MS), as described by Zaugg and others (2002). Samples for analysis of human-health pharmaceuticals were extracted through polystyrene-divinylbenzene cartridges and analyzed by high-performance liquid chromatography/ mass spectrometry (HPLC/MS), as described by Furlong and others (2008). Samples for analysis of pesticides were isolated by solid-phase extraction and analyzed by GC/MS, as described by Zaugg and others (1995), Lindley and others (1996), Sandstrom and others (2001), and Madsen and others (2003). Fluridone was added to the NWQL spiking compound for Schedule 2033 and analyzed using the same methodology and data quality objectives, as described for Schedule 2033. Similarly, 47 additional human-health pharmaceutical compounds were added to the spiking compound for Schedule 1433 and analyzed using the same methodology and data-quality objectives as Schedule 1433. Because the analysis for these additional compounds has not been formally approved by the USGS, the data are not approved for storage in the National Water Information System (NWIS) database.

Test America Laboratory in Arvada, Colorado, under contract with the NWQL, analyzed samples for total suspended solids (TSS). Test America Laboratory analyzes TSS samples by Standard Methods number 2540D (American Public Health Association and others, 1998).

Samples for the analysis of chlorophyll $a$ and pheophytin were filtered in the FSU through glass fiber filters at low vacuum, frozen, and shipped to the NWQL overnight on dry ice. Samples were extracted at the NWQL using an ultrasonic microprobe and quantified by fluorescence (NWQL Schedule 1637), as described by Arar and Collins (1997).

Analysis of fecal-coliform bacteria by membrane filtration using a $0.45-\mu \mathrm{m}$ filter on fecal-coliform agar culture medium followed the procedures described in Standard Methods number 9222D (American Public Health Association and others, 1998). Each water sample required about five plates for the analysis with the first plate and filter consisting of $50 \mathrm{~mL}$ of sterile, phosphate-buffered rinse water (filtration blank). The remaining plates consisted of filtered sample volumes ranging from 3 to $100 \mathrm{~mL}$. The plated filters were cultured in incubators at $44.5 \pm 0.2^{\circ} \mathrm{C}$. After $24 \pm 2$ hours of incubation, the plates were examined for growth of blue colonies. The target colonies were counted (using 10-power magnification, if needed), the numbers recorded on a field sheet, and expressed as a concentration in colony-forming units per $100 \mathrm{~mL}(\mathrm{CFU} / 100 \mathrm{~mL})$ of water.

\section{Quality Assurance}

All field activities for the collection of water-quality samples and water-quality monitoring follow the general guidelines and procedures described in the USGS WAWSC Quality Assurance Plan, as described by Wagner and others (2007). In addition to the maintenance and calibrations of water-quality instruments and onsite documentation previously discussed, a total of 53 quality-control (QC) samples for analyses of nutrients, total-suspended solids, chlorophyll $a$, turbidity, organic compounds, or fecal-coliform bacteria were prepared at the study sites. Of the QC samples, 13 were from the Headworks, Inflow, and Tailrace sites and 40 from the lake sites over the 6-month study (table 3). The field QC samples included replicates to assess total variability in the data due to collection, handling, and laboratory analytical methods; field blanks to evaluate if any positive bias to constituent concentrations was introduced during collection and handling of equipment and sample water; and a field spike to evaluate positive or negative matrix effects on concentrations of organic chemicals. The proportion of QC sample types to the number of environmental samples collected was about 25 percent.

\section{Field Quality Control Samples}

Field-blank samples were subjected to the same conditions and handling as the environmental samples and were prepared onsite with reagent-grade water prior to the collection of environmental sample water. Field blanks for nutrients, chlorophyll $a$, total suspended solids, and turbidity were prepared with water certified for use for inorganic constituents; and field blanks for pesticides, wastewater indicator chemicals, and pharmaceuticals were prepared with organic-free water. Field blanks for fecal-coliform bacteria were prepared with sterile Type I water from the FSU. Typically, the same set of equipment was used for collecting the environmental water. The handling and preparation of equipment for field blank collection and processing followed the guidelines in the National Field Manual (U.S. Geological Survey, 2006). 
Table 3. Types and numbers of quality control samples collected at Lake Tapps, White River (Headworks), White River Canal (Inflow), and Lake Tapps Diversion (Tailrace) sites, Washington, July-December 2010.

[Abbreviation: QC, quality-control sample]

\begin{tabular}{|c|c|c|c|c|c|c|c|}
\hline \multirow[b]{2}{*}{ Month } & \multicolumn{4}{|c|}{ Number of field blanks } & \multicolumn{3}{|c|}{ Number of replicates } \\
\hline & $\begin{array}{l}\text { Nutrients, } \\
\text { Total } \\
\text { suspended } \\
\text { solids, } \\
\text { Turbidity }\end{array}$ & Chlorophyll a & $\begin{array}{l}\text { Fecal } \\
\text { coliform } \\
\text { bacteria }\end{array}$ & $\begin{array}{c}\text { Wastewater } \\
\text { indicator } \\
\text { chemicals, } \\
\text { human-health } \\
\text { pharmaceuticals }\end{array}$ & $\begin{array}{l}\text { Nutrients, } \\
\text { Total } \\
\text { suspended } \\
\text { solids, } \\
\text { Turbidity }\end{array}$ & Chlorophyll a & $\begin{array}{c}\text { Fecal } \\
\text { coliform } \\
\text { bacteria }\end{array}$ \\
\hline \multicolumn{8}{|c|}{ Lake } \\
\hline July & 3 & 2 & 0 & 0 & 2 & 1 & 0 \\
\hline August & 3 & 1 & 1 & 0 & 3 & 1 & 0 \\
\hline September & 4 & 1 & 0 & 1 & 1 & 1 & 2 \\
\hline October & 2 & 1 & 1 & 0 & 2 & 1 & 0 \\
\hline November & 1 & 1 & 0 & 0 & 0 & 0 & 0 \\
\hline December & 1 & 0 & 0 & 0 & 2 & 0 & 0 \\
\hline \multirow[t]{3}{*}{ QC totals each type } & 14 & 6 & 2 & 1 & 10 & 4 & 2 \\
\hline & \multicolumn{4}{|c|}{ Number of field blanks } & \multicolumn{3}{|c|}{ Number of replicates } \\
\hline & \multicolumn{2}{|c|}{$\begin{array}{c}\text { Nutrients, } \\
\text { Total suspended solids, } \\
\text { Turbidity }\end{array}$} & \multicolumn{2}{|c|}{$\begin{array}{l}\text { Fecal coliform } \\
\text { bacteria }\end{array}$} & \multicolumn{2}{|c|}{$\begin{array}{c}\text { Nutrients, } \\
\text { Total suspended solids, } \\
\text { Turbidity }\end{array}$} & $\begin{array}{c}\text { Fecal } \\
\text { coliform } \\
\text { bacteria }\end{array}$ \\
\hline \multicolumn{8}{|c|}{ Headworks, Inflow, Tailrace } \\
\hline July & \multicolumn{2}{|c|}{1} & \multicolumn{2}{|r|}{1} & \multicolumn{2}{|c|}{2} & 0 \\
\hline August & \multicolumn{2}{|c|}{2} & \multicolumn{2}{|r|}{1} & \multicolumn{2}{|c|}{1} & 1 \\
\hline September & \multicolumn{2}{|c|}{0} & \multicolumn{2}{|r|}{0} & \multicolumn{2}{|c|}{0} & 0 \\
\hline October & \multicolumn{2}{|c|}{0} & \multicolumn{2}{|r|}{0} & \multicolumn{2}{|c|}{0} & 0 \\
\hline November & \multicolumn{2}{|c|}{1} & \multicolumn{2}{|r|}{1} & \multicolumn{2}{|c|}{1} & 0 \\
\hline December & \multicolumn{2}{|c|}{0} & \multicolumn{2}{|r|}{0} & \multicolumn{2}{|c|}{0} & 1 \\
\hline QC totals each type & \multicolumn{2}{|c|}{4} & \multicolumn{2}{|r|}{3} & \multicolumn{2}{|c|}{4} & 2 \\
\hline
\end{tabular}

Summary of quality control samples

\begin{tabular}{l|c|c}
\hline \multicolumn{1}{c}{ Sample type } & $\begin{array}{c}\text { Numbers } \\
\text { for lake }\end{array}$ & $\begin{array}{c}\text { Numbers } \\
\text { for river }\end{array}$ \\
\hline Blanks & 23 & 7 \\
Replicates & 16 & 6 \\
Organic matrix spike & 1 & 0 \\
\hline Total & 40 & 13 \\
\hline
\end{tabular}


Replicate samples were of two types—split and sequential. Split-replicate samples simply involved collecting enough water to fill the churn and split out two sets of sample bottles for whole water analyses and filter remaining water for two sets of filtered water. Split-replicate samples from churn splitters were prepared at the Headworks, Inflow, and Tailrace sites and at the lake sites when churn splitters were used to composite water from different sampling depths. Sequential-replicate samples were prepared at lake sites when churn splitters were not used, by pumping through the sampling lines and sequentially filling two sets of bottles with whole-water and two sets of bottles with filtered water.

The matrix-spike organic samples were split-replicate samples consisting of multiple 1-L glass bottles filled from the churn splitter and held on ice for transport to the FSU. At the FSU, the raw water was filtered into another set of clean 1-L glass bottles and shipped on ice to the NWQL for organic chemical analyses. The bottle of filtered water to be analyzed for wastewater indicator chemicals was spiked with $0.1 \mathrm{~mL}$ of a spike solution containing a mix of target analytes in known concentrations (for Schedule 1433). A second bottle of filtered water for analysis of human-health pharmaceuticals (by Schedule 2080) was shipped on ice to the NWQL and spiked in the laboratory.

\section{Laboratory Quality Control Samples}

In addition to quality-assurance procedures used in the field, the NWQL also follows general guidelines and procedures to ensure quality work procedures and results as described by Maloney (2005). The NWQL routinely follows standard operating procedures for the analysis of all constituents; follows accepted procedures for instrument calibration; and utilizes instrument blanks, laboratory replicates, and continuing calibration verification standards to ensure the quality of analyzed data. These internal quality-control procedures are augmented by analysis of samples in several external standard reference programs, such as participation in the USGS Branch of Quality Systems NWQL Blind Blank Program, Inorganic Blind Sample program, and Organic Blind Blank program (U.S. Geological Survey, 2010) . Results from these internal quality-control procedures indicated the NWQL data quality to be within acceptable limits during the period of this study.

\section{Analytical Results for Quality Control Samples}

Field blanks for the Headworks, Inflow, and Tailrace sites were free of detections of total suspended solids, nitrite, nitrite-plus-nitrate nitrogen, orthophosphate phosphorus, filtered and total phosphorus, unfiltered total nitrogen, and fecal-coliform bacteria (appendix table D1). Ammonia was detected in all four field-blank samples and filtered total nitrogen was detected in three of the field blanks at low concentrations near the laboratory reporting or method detection levels. Corresponding environmental sample concentrations were all less than the laboratory reporting level and therefore do not exhibit a positive bias (table 4A). The exception may be for the field-blank and environmental samples collected on August 17, 2010, at the Inflow site in which filtered total-nitrogen and ammonia concentrations were nearly the same (appendix table D1). Turbidities analyzed in the FSU using a HACH 2100P were consistently about 0.1 NTRU, which do not affect environmental values that were one to two orders of magnitude greater than the field-blank value.

Relative percent differences among 42 pairs of replicate concentrations from the Headworks, Inflow, and Tailrace sites ranged from 0 to 66.7 percent, with more than one-half of the 42 replicate pairs greater than an acceptable limit of less than 5-percent relative difference (table $4 B$ ). The largest difference (66.7 percent) was observed in one pair of filtered nitrite concentrations, followed by 44.2 percent for one pair of filtered total nitrogen concentrations (appendix table D1). Concentration data reported for all constituents include total variation (errors) accumulated through sampling, processing, and analysis. In addition, random bias, as shown in blank concentrations (table 4A) increases variation. For example, concentrations of filtered total nitrogen in field blanks ranged from 0.06 to $0.21 \mathrm{mg} / \mathrm{L}$ and these random detections are reflected in the 8-44.2 percent relative differences observed between replicate pairs of filtered total nitrogen (table $4 B$ ). Measurement of variability in concentrations that are at or near the limit of detection may result in a large relative percent difference. For example, the pair of nitrite concentrations in samples from the Tailrace site during November 2010 (0.001 and $0.002 \mathrm{mg} / \mathrm{L}$ ) is reported to three significant digits and the small difference between these concentrations results in a large relative percent difference. Another source of variability in replicates of nutrient analyses can be due to the tendency for nitrogen and phosphorus to adsorb to particles. Some of the variation seen in unfiltered nutrient concentrations may be a reflection of the variation seen in the turbidity and suspended solids replicates (table $4 B$ ). 
Table 4. Summary of analytical results for $(A)$ field-blank samples and corresponding environmental water samples and $(B)$ relative percent difference between pairs of samples collected from White River (Headworks), White River Canal (Inflow), and Lake Tapps Diversion (Tailrace) sites, Washington, July-December 2010.

[A bbreviations: mg/L, milligram per liter; NTRU nephelometric turbidity ratio units; e, estimated; <, less than]

\begin{tabular}{|c|c|c|c|c|}
\hline \multicolumn{5}{|c|}{ A. Field blank samples and corresponding environmental water samples } \\
\hline \multirow[b]{2}{*}{ Constituent } & \multicolumn{3}{|c|}{ Field blanks } & \multirow{2}{*}{$\begin{array}{c}\text { Environmental } \\
\text { water } \\
\text { sample } \\
\text { concentration }\end{array}$} \\
\hline & $\begin{array}{l}\text { Total number } \\
\text { of samples }\end{array}$ & $\begin{array}{l}\text { Number of } \\
\text { samples with } \\
\text { detections }\end{array}$ & $\begin{array}{c}\text { Sample } \\
\text { concentration }\end{array}$ & \\
\hline \multirow[t]{4}{*}{ Ammonia nitrogen, filtered (mg/L) } & 4 & 4 & e0.014 & $<0.01$ \\
\hline & & & e0.012 & $\mathrm{e} 0.013$ \\
\hline & & & e0.012 & $<0.01$ \\
\hline & & & 0.018 & 0.018 \\
\hline Nitrite plus nitrate nitrogen, filtered $(\mathrm{mg} / \mathrm{L})$ & 4 & 1 & $\mathrm{e} 0.013$ & 0.028 \\
\hline \multirow[t]{3}{*}{ Total nitrogen, filtered $(\mathrm{mg} / \mathrm{L})$} & 4 & 3 & 0.21 & $<0.05$ \\
\hline & & & e0.1 & 0.14 \\
\hline & & & e0.06 & $<0.05$ \\
\hline \multirow[t]{3}{*}{ Turbidity, NTRU } & 4 & 3 & 0.1 & 30 \\
\hline & & & 0.1 & 9.1 \\
\hline & & & 0.1 & 2.5 \\
\hline
\end{tabular}

B. Relative percent difference between pairs of samples collected from Headworks, Inflow, and Tailrace

\begin{tabular}{|c|c|c|c|c|c|}
\hline \multirow{2}{*}{ Constituent } & \multirow{2}{*}{$\begin{array}{c}\text { Number } \\
\text { of sample } \\
\text { pairs }\end{array}$} & \multirow{2}{*}{$\begin{array}{c}\text { Number of samples } \\
\text { with difference } \\
\text { greater than } \\
5 \text { percent }\end{array}$} & \multicolumn{3}{|c|}{$\begin{array}{l}\text { Relative difference } \\
\text { (percent) }\end{array}$} \\
\hline & & & Median & Minimum & Maximum \\
\hline Ammonia nitrogen, filtered & 4 & 3 & 9.1 & 0 & 37.5 \\
\hline $\begin{array}{l}\text { Nitrite plus nitrate nitrogen, } \\
\text { filtered }\end{array}$ & 4 & 2 & 5.7 & 0 & 22.2 \\
\hline Nitrite nitrogen, filtered & 4 & 1 & 0 & 0 & 66.7 \\
\hline $\begin{array}{l}\text { Orthophosphate phosphorus, } \\
\text { filtered }\end{array}$ & 4 & 1 & 0 & 0 & 9.5 \\
\hline Phosphorus, filtered & 4 & 1 & 0 & 0 & 13.3 \\
\hline Phosphorus, unfiltered & 4 & 3 & 9.2 & 3.5 & 26.3 \\
\hline Total nitrogen, filtered & 4 & 4 & 11.6 & 8.0 & 44.2 \\
\hline Total nitrogen, unfiltered & 4 & 3 & 10.1 & 0 & 40.0 \\
\hline Total suuspended solids & 4 & 3 & 9.1 & 0 & 20.0 \\
\hline Turbidity & 4 & 2 & 6.2 & 1.8 & 20.6 \\
\hline Fecal-coliform bacteria & 2 & 2 & 26.8 & 22.2 & 31.3 \\
\hline
\end{tabular}


Field blanks for Lake Tapps sites were free of detections of nitrite nitrogen, orthophosphate phosphorus, filtered and total phosphorus, filtered total nitrogen, chlorophyll $a$ and pheophytin $a$, and fecal-coliform bacteria (appendix table D2). Nitrite-plus-nitrate nitrogen and unfiltered total nitrogen were each detected in 1 of the 14 field-blank samples. The nitriteplus-nitrate concentration of $0.01 \mathrm{mg} / \mathrm{L}$ detected in the blank sample from Lake Inlet on July 20, 2010, is near the method detection level of $0.008 \mathrm{mg} / \mathrm{L}$. The unfiltered total nitrogen concentration of $0.13 \mathrm{mg} / \mathrm{L}$ in the blank sample from Allan Yorke site on August 3, 2010, is the same as the concentration of the environmental sample (appendix table D2). Extensive flushing of the sampling lines with lake water before the sample collection probably minimized or eliminated potential residual contaminants and any positive bias to water samples. Concentrations of ammonia in 4 of the 14 field-blank samples were present at low concentrations near the method detection level of $0.01 \mathrm{mg} / \mathrm{L}$ and similar to the concentration in the environmental samples. Turbidities analyzed in the FSU using a HACH 2100P showed consistent low-level values for the 14 field-blank samples, ranging from 0.07 to 0.19 NTRU with a median of 0.12 NTRU. This low level likely indicates a background level associated with the reagent waters and instrumentation and not a contamination bias to samples from collection and handling. Turbidity in lake water samples were at least three times greater than field-blank values (table 5). Three organic compounds-isophorone, benzophenone, and phenol - were detected in the field-blank sample prepared at the Lake Outlet site in September (appendix table D3). The detection of these compounds did not alter the sample concentrations because the compounds were reported as less than the laboratory reporting level or reported as measured and detected, but not quantified.

Table 5. Constituent concentrations in field-blank samples with detections at or greater than laboratory method detection or reporting levels, and concentrations in corresponding water samples from Lake Tapps, Washington, July-December 2010.

[See appendixes for all quality-control analytical results. A bbreviations: mg/L, milligram per liter; NTRU nephelometric turbidity ratio units; $\mu \mathrm{g} / \mathrm{L}$, microgram per liter; e, estimated; <, less than; $\mathrm{n}$, less than the laboratory reporting level and greater than the long-term method detection level; M, presence of analyte verified, but not quantified]

\begin{tabular}{|c|c|c|c|c|}
\hline \multirow[b]{2}{*}{ Constituent } & \multicolumn{3}{|c|}{ Field blanks } & \multirow{2}{*}{$\begin{array}{l}\text { Lake-water } \\
\text { sample } \\
\text { concentration }\end{array}$} \\
\hline & $\begin{array}{l}\text { Total number } \\
\text { of samples }\end{array}$ & $\begin{array}{c}\text { Number of } \\
\text { samples with } \\
\text { detection }\end{array}$ & $\begin{array}{c}\text { Sample } \\
\text { concentration }\end{array}$ & \\
\hline Ammonia nitrogen, filtered $(\mathrm{mg} / \mathrm{L})$ & 14 & 4 & $\begin{array}{c}0.01 \\
0.011 \\
\mathrm{e} 0.014 \\
0.02\end{array}$ & $\begin{array}{r}0.011 \\
0.012 \\
<0.010 \\
0.031\end{array}$ \\
\hline Nitrite plus nitrate nitrogen, filtered (mg/L) & 14 & 1 & e0.01 & $<0.008$ \\
\hline Total nitrogen, unfiltered (mg/L) & 14 & 1 & 0.13 & 0.13 \\
\hline Turbidity (NTRU) & 14 & 14 & $\begin{array}{l}0.07 \\
0.08 \\
0.08 \\
0.08 \\
0.08 \\
0.09 \\
0.11 \\
0.14 \\
0.14 \\
0.17 \\
0.17 \\
0.19 \\
0.19 \\
0.19\end{array}$ & $\begin{array}{l}1.2 \\
3.2 \\
0.7 \\
1.8 \\
1.6 \\
0.8 \\
0.6 \\
0.7 \\
2.5 \\
0.7 \\
1.5 \\
1.1 \\
0.6 \\
0.6\end{array}$ \\
\hline Isophorone, filtered $(\mu \mathrm{g} / \mathrm{L})$ & 1 & 1 & e0.033 & M \\
\hline Phenol, filtered $(\mu \mathrm{g} / \mathrm{L})$ & 1 & 1 & n0.14 & $<0.16$ \\
\hline Benzophenone, filtered $(\mu \mathrm{g} / \mathrm{L})$ & 1 & 1 & 0.046 & M \\
\hline
\end{tabular}


Constituent concentrations in replicate samples from the lake sites generally agreed within acceptable limits of less than 5-percent relative difference, except for fecal-coliform bacteria, filtered and unfiltered total nitrogen, and unfiltered total phosphorus (table 6). The analytical results for the three sample pairs of fecal-coliform bacteria showed the greatest variability with relative differences of 35.1, 66.7, and 93.3 percent. On the basis of medians, the constituents with the next largest variability after the bacteria were unfiltered and filtered total nitrogen with differences of 12.0 and 8.2 percent, respectively (table 6).

Of the compounds in Schedules 2080 and 1433, only prometon and DEET in Schedule 1433 were detected at a level that provided a sufficient background concentration for calculating a matrix-spike recovery. Recoveries for these two compounds were 95 and 99 percent, respectively. All other recoveries were calculated with background-sample values reported as less than the laboratory reported level and shown as ranges of spike recovery. This range uses zero for the lowest possible concentration and the laboratory reporting level for the highest possible concentration. Recoveries of two compounds for Schedule 2080, sulfamethoxazole and thiabendazole, were less than 60 percent for the high value of the calculated range. In the methods development testing of South Platte River and Boulder Creek water (Furlong and others, 2008), recoveries of these two pharmaceuticals also were low at less than 50 percent. Ten compounds in Schedule 1433 had recoveries at the high end of the calculated ranges that were less than 60 percent (table 7).

Table 6. Summary of relative percent difference among pairs of samples collected from Lake Tapps sites, Washington, July-December 2010.

[All samples filtered unless indicated]

\begin{tabular}{|c|c|c|c|c|c|}
\hline \multirow{2}{*}{ Constituent } & \multirow{2}{*}{$\begin{array}{c}\text { Number } \\
\text { of sample } \\
\text { pairs }\end{array}$} & \multirow{2}{*}{$\begin{array}{l}\text { Number of samples } \\
\text { with difference } \\
\text { greater than } \\
5 \text { percent }\end{array}$} & \multicolumn{3}{|c|}{ Relative difference (percent) } \\
\hline & & & Median & Minimum & Maximum \\
\hline Ammonia nitrogen & 10 & 4 & 1.6 & 0 & 27.8 \\
\hline Chlorophyll $a$ & 4 & 0 & 2.1 & 0 & 4.8 \\
\hline Fecal coliform bacteria & 3 & 3 & 66.7 & 35.1 & 93.3 \\
\hline Nitrite plus nitrate nitrogen & 10 & 2 & 0.0 & 0 & 17.4 \\
\hline Nitrite nitrogen & 10 & 2 & 0.0 & 0 & 14.5 \\
\hline Orthophosphate phosphorus & 10 & 3 & 0.6 & 0 & 24.5 \\
\hline Phosphorus & 10 & 3 & 0.9 & 0 & 6.6 \\
\hline Phosphorus, unfiltered & 10 & 5 & 5.4 & 0 & 26.6 \\
\hline Total suspended solids, unfiltered & 10 & 4 & 0.0 & 0 & 40.0 \\
\hline Total nitrogen & 8 & 5 & 8.2 & 0.8 & 40.8 \\
\hline Total nitrogen, unfiltered & 10 & 10 & 12.0 & 6.0 & 59.4 \\
\hline Turbidity, unfiltered & 10 & 3 & 3.4 & 0 & 49.8 \\
\hline
\end{tabular}


Table 7. Wastewater indicator compounds of analytical Schedule 1433 with low recoveries of a fortified matrix spike solution in sample water from the Lake Outlet (fig. 4, map No. L8) site on Lake Tapps, Washington, September 22, 2010.

[A bbreviations: $\mu \mathrm{g} / \mathrm{L}$, microgram per liter; <, less than; e, estimated]

\begin{tabular}{|c|c|c|c|c|}
\hline $\begin{array}{l}\text { Parameter } \\
\text { code }\end{array}$ & Wastewater indicator compound & $\begin{array}{c}\text { Background } \\
\text { concentration } \\
(\mu \mathrm{g} / \mathrm{L})\end{array}$ & $\begin{array}{c}\text { Matrix-spike } \\
\text { concentration } \\
(\mu \mathrm{g} / \mathrm{L})\end{array}$ & $\begin{array}{l}\text { Recovery range } \\
\text { (percent) }\end{array}$ \\
\hline 62059 & 3-tert-Butyl-4-hydroxyanisole ${ }^{1}$ & $<8$ & e 0.092 & $-475-5.5$ \\
\hline 34476 & Tetrachloroethene $^{1}$ & $<0.12$ & $\mathrm{e} 0.32$ & $12-19.2$ \\
\hline 62073 & $d$-Limonene ${ }^{1}$ & $<0.08$ & 0.52 & $26.4-31.2$ \\
\hline 62076 & Indole & $<0.08$ & 0.096 & $6.4-38.4$ \\
\hline 62068 & beta-Sitosterol & $<4$ & e 3.8 & $-2.5-47.5$ \\
\hline 62061 & 4-n-Octylphenol ${ }^{1}$ & $<0.16$ & e0.1 & $-28.8-48.1$ \\
\hline 62063 & 5-Methyl-1H-benzotriazole & $<1.2$ & 1.7 & 15-51.1 \\
\hline 62086 & beta-Stigmastanol & $<2.6$ & e1.1 & $-72.1-52.9$ \\
\hline 62078 & Isopropylbenzene ${ }^{1}$ & $<0.3$ & 0.23 & $-16.8-55.3$ \\
\hline 34288 & Tribromomethane $^{1}$ & $<0.1$ & 0.99 & $53.5-59.5$ \\
\hline
\end{tabular}

${ }^{1}$ Compounds with low recovery, high variable recovery, unstable instrument response, or from a technical mixture to be reported with an estimated (e) code from testing during method development.

\section{Environmental and Hydrologic Conditions During the Sample-Collection Period}

Weather records by the National Weather Service at SeaTac Airport generally showed below-normal temperatures and above-normal rainfall during the period of study (National Climatic Data Center, 2010). Average departure of air temperatures from normal monthly temperatures were $-0.7^{\circ} \mathrm{F}$ during July; $-0.2^{\circ} \mathrm{F}$ during July and September; and $0.6^{\circ} \mathrm{F}$ during October. The first sampling event in early July (July 6-8) followed a cooler than normal June with air temperatures averaging $2.4^{\circ} \mathrm{F}$ below normal, and the last sampling event in early December (December 7-8) followed a cooler than normal November with an average temperature of $2.0^{\circ} \mathrm{F}$ below normal. Rainfall for July and August was below normal at 0.48 and 0.38 in., respectively. However, September and October rainfall was 3.17 and 2.05 in. above normal, respectively. By the end of October, precipitation was 6.89 in. above normal for the year. The first sampling event in July (July 6-8) followed a wet June, with precipitation totaling
1 in. above normal, and the last sampling event in December (December 7-8) followed a drier than normal November with precipitation nearly $1 \mathrm{in}$. below the normal of $5.9 \mathrm{in}$.

July and August samples were collected during generally warm and dry weather. However, weather conditions often varied on a daily basis over the course of sampling. For example, during the first sampling event in early July, air temperatures rose from a high of $64^{\circ} \mathrm{F}$ on July 6 , the first day of sampling, to $86^{\circ} \mathrm{F}$ on July 8, the third day of sampling. Similarly, on August 3, the weather was cloudy, foggy, and cool, but on the second day of sampling (August 4), the sky was clear with bright sun (appendix A). The first sampling event in September (September 7-8) occurred during 3 days of substantial rainfall totaling more than 1.6 in., as measured at nearby McMillin Reservoir, a National Oceanic and Atmospheric Administration (2011) National Weather Service site (station 45-5224-03) operated by the city of Tacoma. Wet weather dominated sampling conditions during the remainder of the study from late September through early December, either by raining for a few days prior to, or by raining on the day of collection (fig. 6). 


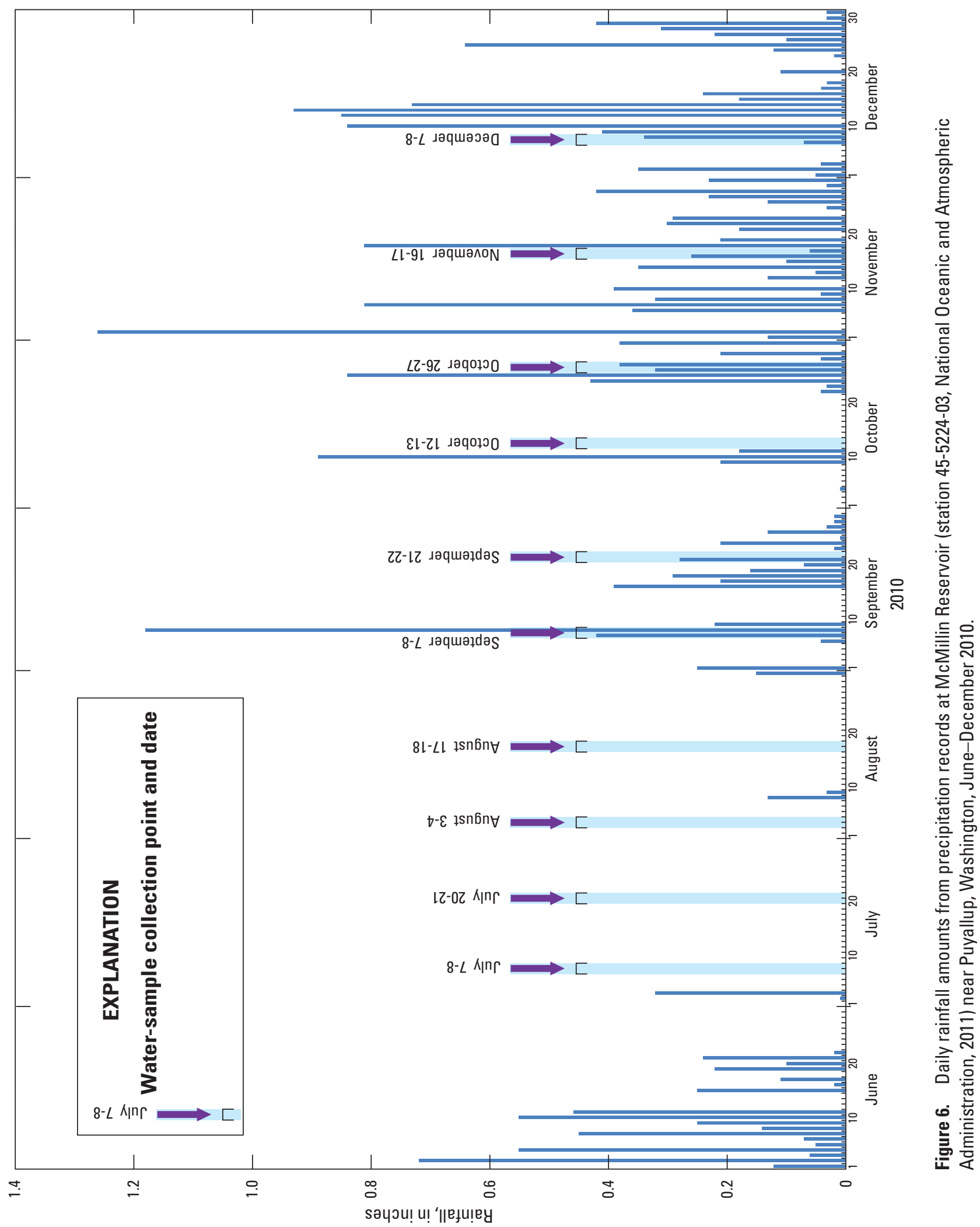


Wind and waves occasionally affected sampling conditions at some lake sites. Although wind waves typically were less than about $1 \mathrm{ft}$ high, wakes from boats and personal watercraft at several sites on the sunny and warm days of July and August could have affected the position of the sampling-tube orifice in the water column and Secchi disk measurements (appendix A).

Beginning in late August 2010, Cascade Water Alliance closed the gates that divert water from the White River into the White River Canal and cleared all water from the Headworks to the twin pipe inlet structure east of Printz Basin. This dewatering process allowed staff to examine and repair structures and facilities in the White River Canal. Because there was no water being diverted at the Headworks and minimal water was being released from Lake Tapps from March through October, sampling at the Headworks, Inflow, and Tailrace sites was discontinued in late August (fig. 7). In preparation for winter drawdown, water was released from Lake Tapps in November 2010 (fig. 8), and the Tailrace was sampled two additional times during November and December.

With water diversions from the White River into the White River Canal, filling of Lake Tapps reservoir began in mid-March 2010. By late April, the reservoir was at the target water-surface elevation of about $542 \mathrm{ft}$. Water-quality sampling occurred with steady water-surface elevation until mid-October when Cascade Water Alliance began releasing water and lowering the lake. By the last sampling of the lake in December, the water level had declined to about 539 ft above NGVD 29.
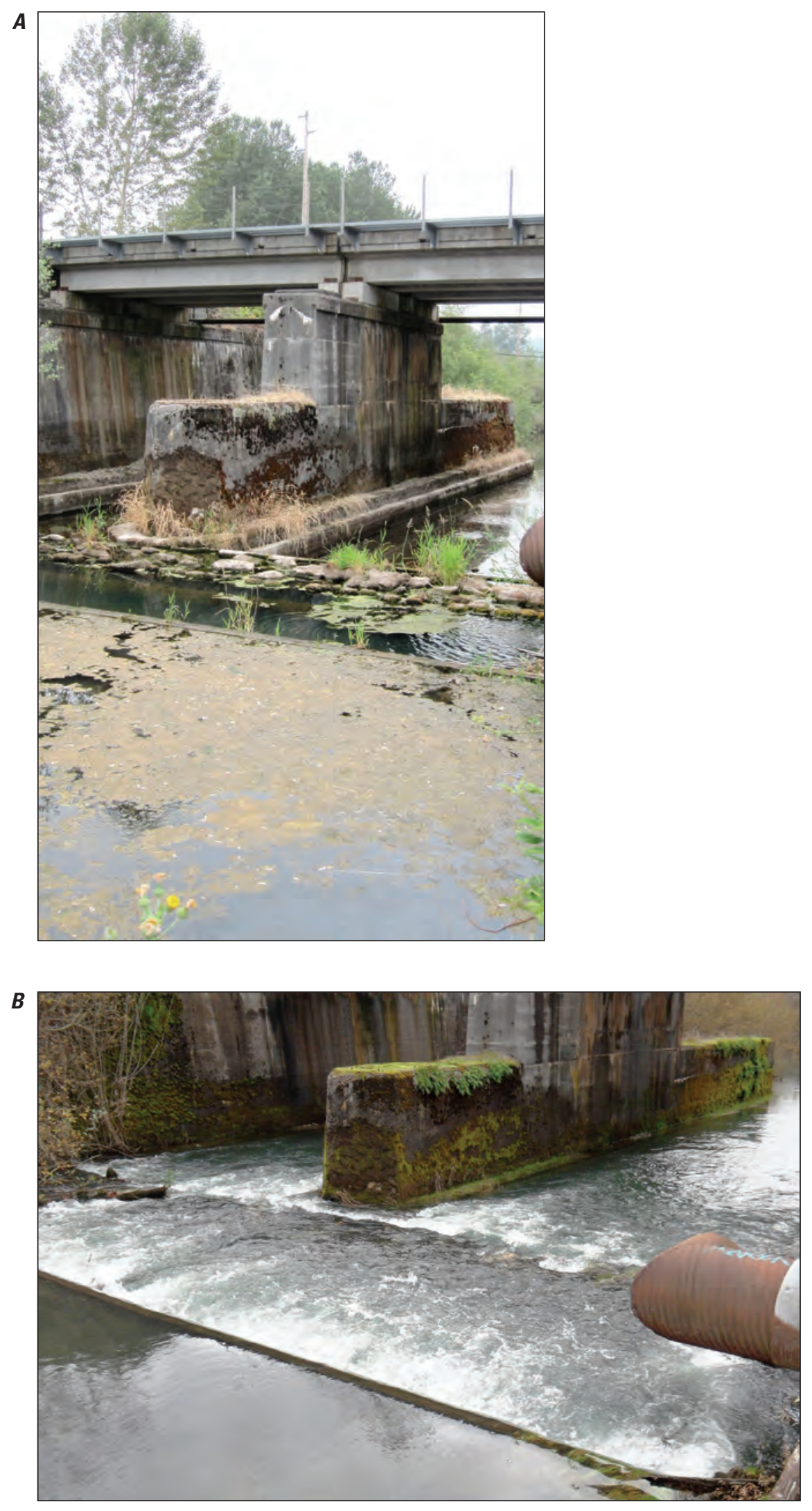

Figure 7. Lake Tapps Diversion downstream of the Dieringer powerhouse (Tailrace) at no-flow, stagnant condition $(A)$ and at a flow of 100 cubic feet per second $(B)$. 


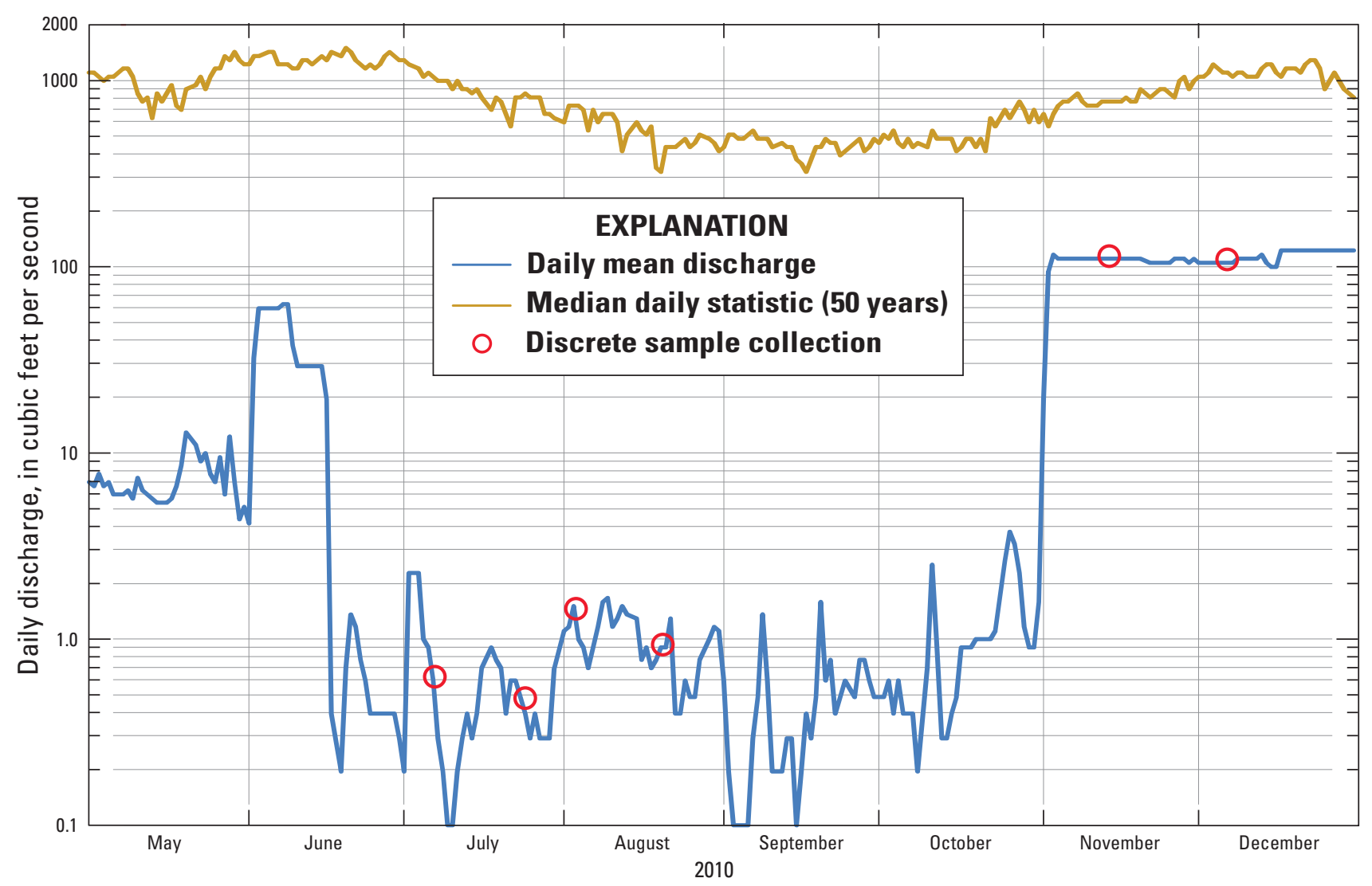

Figure 8. Daily discharge hydrograph for stream-gaging station 12101100, Lake Tapps Diversion at Dieringer (Tailrace), Washington, May-December 2010.

\section{Quality of Water in the White River, White River Canal, Lake Tapps Diversion, and Lake Tapps}

This section presents summaries and discussions of the water-quality data collected from sampling and monitoring sites on the White River, White River Canal (Inflow),

Lake Tapps Diversion (Tailrace), and Lake Tapps from May to December 2010. Discussion of the water quality of the White River, Inflow, and Tailrace system is presented first followed by descriptions of the quality of water in Lake Tapps. Where appropriate, the data obtained from this study are referenced to standards or criteria established by the State of Washington $(2006,2011)$ for the protection of aquatic life and recreation designated uses (table 8).

\section{Quality of Water in the White River (Headworks), White River Canal (Inflow), and Lake Tapps Diversion (Tailrace)_- Discrete Samples}

\section{Physical Properties}

Because the source of the White River is from glaciers on Mount Rainier, the river transports fine glacier material that frequently gives the river a whitish color, especially during summer. The three sites sampled were relatively turbid, with median turbidity of 59 NTRU at the Headworks site, 16 NTRU at the Inflow site, and 6.8 NTRU at the Tailrace site. The turbidity measured from samples collected at all three sites during the study ranged from 2.4 NTRU at the Tailrace site to 340 NTRU at the Headworks site (table 9). 
Table 8. Summary of Washington State freshwater aquatic life and recreation designated uses and criteria.

[A bbreviations: ${ }^{\circ} \mathrm{C}$, degrees Celsius; mg/L, milligram per liter; mL, milliliter; $\mathrm{CFU} / 100 \mathrm{~mL}$, colony-forming units per 100 milliliters]

\begin{tabular}{|c|c|}
\hline Category & 7-day average of daily maximum temperatures \\
\hline Salmon and trout spawning and incubation ${ }^{1}$ & $13^{\circ} \mathrm{C}$ \\
\hline Core summer salmonid habitat $^{2}$ & $16^{\circ} \mathrm{C}$ \\
\hline Salmonid spawning, rearing, and migration ${ }^{3}$ & $17.5^{\circ} \mathrm{C}$ \\
\hline
\end{tabular}

\begin{tabular}{|l|c|}
\hline \multicolumn{1}{|c|}{ B. Aquatic Life Dissolved Oxygen Criteria $^{4}$} \\
\hline \multicolumn{1}{|c|}{ Category } & Lowest 1-day minimum \\
\hline Core summer salmonid habitat $^{2}$ & $9.5 \mathrm{mg} / \mathrm{L}$ \\
\hline Salmonid spawning, rearing, and migration & 3 \\
\hline
\end{tabular}

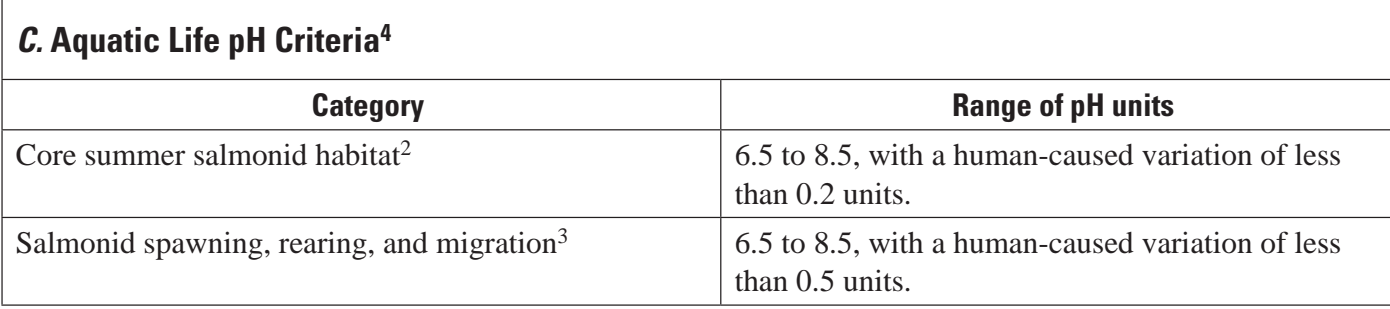

\begin{tabular}{|l|c|}
\hline \multicolumn{2}{|c|}{ D. Water Contact Recreation Bacteria Criteria } \\
\multicolumn{1}{|c|}{ Category } & \multicolumn{2}{|c|}{ Fecal-coliform bacteria single-sample limits } \\
\hline Extraordinary primary contact recreation $^{5}$ & $100 \mathrm{CFU} / 100 \mathrm{~mL}$. \\
\hline Primary contact recreation $^{6}$ & $200 \mathrm{CFU} / 100 \mathrm{~mL}$. \\
\hline
\end{tabular}

${ }^{1}$ September 15-July 1 for the reach of the White River upstream of latitude $47^{\circ} 14^{\prime} 37.68^{\prime \prime}$ longitude $122^{\circ} 14^{\prime} 31.91^{\prime \prime}$ to the diversion dam and excluding the Muckleshoot Indian Reservation (Washington State Department of Ecology, 2006).

${ }^{2}$ For reaches of the White River from latitude $47^{\circ} 14^{\prime} 37.68^{\prime}$ ' longitude $122^{\circ} 14^{\prime} 31.91$ ” to Mud Mountain dam (Washington State Department of Ecology, 2011, table 602).

${ }^{3}$ For reaches of the White River downstream of latitude $47^{\circ} 14^{\prime} 37.68^{\prime \prime}$ longitude $122^{\circ} 14^{\prime} 31.91^{\prime \prime}$ (Washington State Department of Ecology, 2011, table 602).

${ }^{4}$ Washington State Department of Ecology (2011).

${ }^{5}$ For Lake Tapps and reaches of the White River above Mud Mountain Dam (Washington State Department of Ecology, 2011, table 602).

${ }^{6}$ For reaches of the White River from the mouth to Mud Mountain Dam (Washington State Department of Ecology, 2011, table 602). 
Table 9. Summary statistics of water-quality properties and concentrations of nutrients, total suspended solids, and fecalcoliform bacteria for the study sites on the White River (Headworks), White River Canal (Inflow), and Lake Tapps Diversion (Tailrace), Washington, July-December 2010.

[Site: Headworks, White River at Headworks above Flume near Buckley, Washington, USGS, 12098700. Inflow, White River Canal at $218^{\text {th }}$ Street E, above Lake Tapps near Buckley, Washington, USGS, 12099060. Tailrace, Lake Tapps Diversion at Dieringer, Washington, USGS, 12101100. Number of samples for Headworks, Inflow, and Tailrace sites equals 4, 4, and 6, respectively. A bbreviations: mg/L, milligram per liter; $\mu \mathrm{S} / \mathrm{cm}$, microsiemens per centimeter at $25^{\circ} \mathrm{C}$; ${ }^{\circ} \mathrm{C}$, degrees Celsius; NTRU, nephelometric turbidity ratio units; $\mathrm{mL}$, milliliter; <, less than]

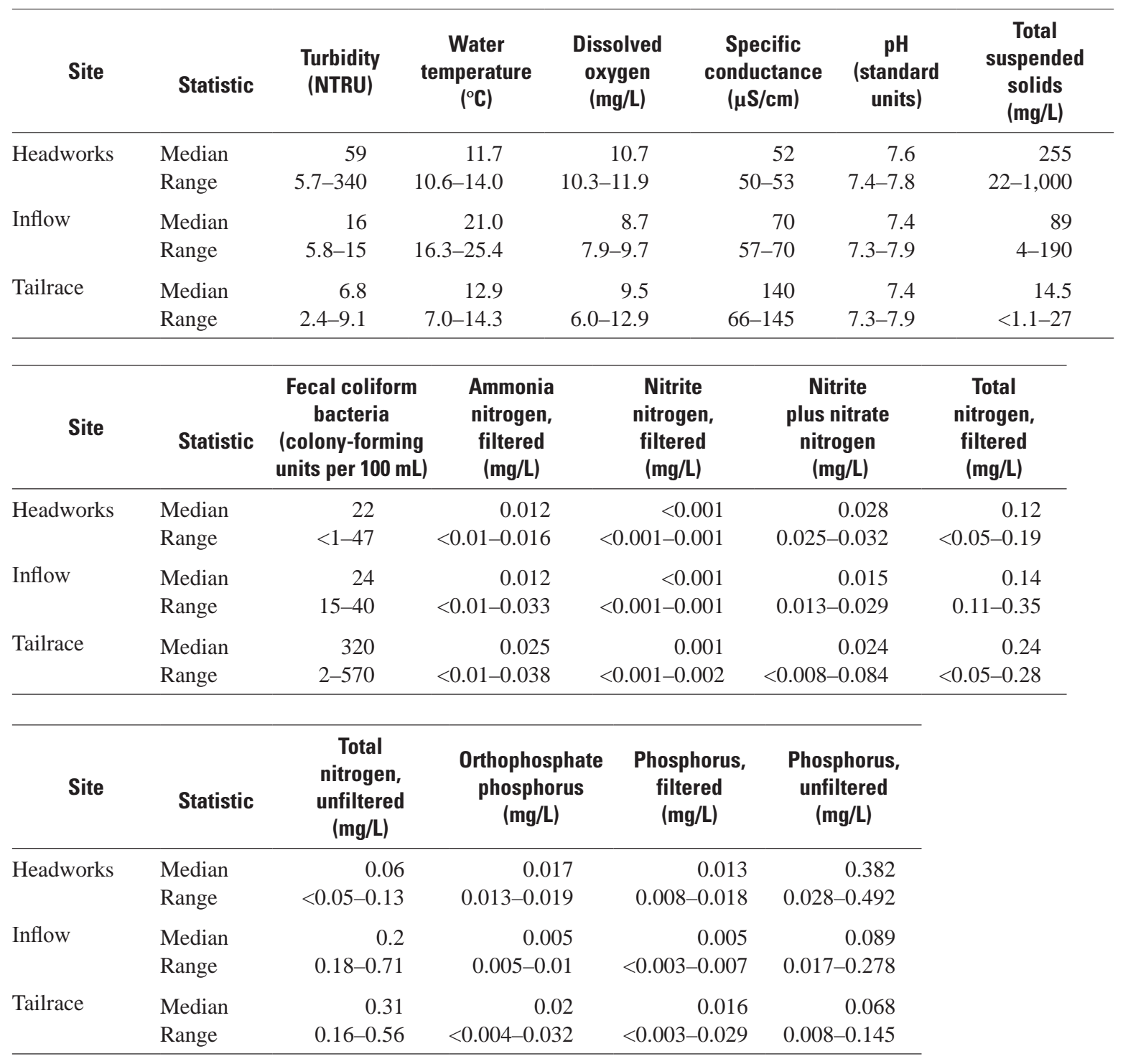


The water temperature of the White River is moderated somewhat by residence time upstream of Mud Mountain Dam and generally becomes progressively warmer at downstream sites. Median water temperatures in samples collected during the study were $11.7^{\circ} \mathrm{C}$ at the Headworks site, $21.0^{\circ} \mathrm{C}$ at the Inflow site, and $12.9^{\circ} \mathrm{C}$ at the Tailrace site. The temperature measured from samples collected at all three sites during the study ranged from a minimum of $7.0^{\circ} \mathrm{C}$ at the Tailrace site to a maximum of $25.4^{\circ} \mathrm{C}$ at the Inflow site (table 9). The warmer temperatures at the Inflow site were due to the reduced flow diverted from the river to the White River Canal during 2010, and the Inflow site was essentially a stagnant pool during the latter half of the year. The median water temperature at the Tailrace site generally was warmer than at the Headworks site because the lake outlet is at a mid-to-lower lake elevation during summer, and the water being drawn from the lake is usually cooler than the surface of the lake but warmer than the river. Because flow from the White River to the White River Canal was suspended in late August to repair the wooden flume, the Headworks and Inflow sites were sampled only four times. However, water was released from Lake Tapps in November and, with flow restored to the Tailrace, the site was sampled once in November and once in December, which explains the minimum temperature during the study at the Tailrace site.

The White River generally is well-oxygenated, and the median dissolved oxygen concentration in samples collected during the study was $10.7 \mathrm{mg} / \mathrm{L}$ at the Headworks site. The suspension of the diversion of river water into the White River Canal for flume maintenance that resulted in warm water at the Inflow site also resulted in generally low concentrations of dissolved oxygen. The median dissolved oxygen concentration at the Inflow site was $8.7 \mathrm{mg} / \mathrm{L}$ and concentrations ranged from 7.9 to $9.7 \mathrm{mg} / \mathrm{L}$. Flow also was reduced from the Lake Tapps Powerhouse in order to make valve repairs and to assist in maintaining the Lake Tapps summer elevation. Because the flow in the Tailrace was reduced to nearly zero from mid-June until early November, the water was less oxygenated and more influenced by metabolic processes from bacteria, algae, and macrophytes growing in the stream. The median dissolved oxygen concentration in samples collected during the study at the Tailrace site was $9.5 \mathrm{mg} / \mathrm{L}$. The dissolved oxygen measured from samples collected at all three sites during the study ranged from a minimum of $6.0 \mathrm{mg} / \mathrm{L}$ to a maximum of $12.9 \mathrm{mg}$ / (both at the Tailrace site, table 9). The dissolved oxygen concentration of $6.0 \mathrm{mg} / \mathrm{L}$ measured on August 17, 2010, is lower than all categories of freshwater Aquatic Life Dissolved Oxygen Criteria established by the Washington State Department of Ecology (2011) (table 8).
The composition of the water in the White River, based on specific conductance and $\mathrm{pH}$, generally is dilute and near neutrality. Median specific conductance values in samples collected during the study were $52 \mu \mathrm{S} / \mathrm{cm}$ at the Headworks site, $70 \mu \mathrm{S} / \mathrm{cm}$ at the Inflow site, and $140 \mu \mathrm{S} / \mathrm{cm}$ at the Tailrace site. Specific-conductance measurements made at all three sites during the study ranged from $50 \mu \mathrm{S} / \mathrm{cm}$ at Headworks to $145 \mu \mathrm{S} / \mathrm{cm}$ at the Tailrace (table 9). The $\mathrm{pH}$ is a measure of the acidity or basicity of aqueous solutions and is influenced by the dissolved constituents and biological processes occurring in the waterbody. The median $\mathrm{pH}$ in samples collected during the study were $7.6 \mathrm{pH}$ units at the Headworks site and $7.4 \mathrm{pH}$ units at the Inflow and Tailrace sites. The $\mathrm{pH}$ measurements made at all three sites during the study ranged from $7.3 \mathrm{pH}$ units at the Inflow and Tailrace sites to $7.9 \mathrm{pH}$ units at the Inflow and Tailrace sites (table 9).

\section{Total Suspended Solids and Bacteria}

The USGS traditionally uses measurements of suspended-sediment concentration as the most accurate method to measure suspended material in a sample collected from a stream (American Society for Testing and Materials, 2007). However, because TSS data have been used as a surrogate for suspended-sediment concentrations and because TSS is the appropriate measurement for the lake (non-flowing water), the TSS analysis was selected as a common measure for river and lake samples. The median concentrations of TSS in samples collected during the study were $255 \mathrm{mg} / \mathrm{L}$ at the Headworks site, $89 \mathrm{mg} / \mathrm{L}$ at the Inflow site, and $14.5 \mathrm{mg} / \mathrm{L}$ at the Tailrace site. TSS measured at all three sites during the study ranged in concentration from less than $1.1 \mathrm{mg} / \mathrm{L}$ (the minimum reporting level) at Tailrace to $1,000 \mathrm{mg} / \mathrm{L}$ at Headworks (table 9).

The microbial quality of the surface water was measured by analyzing for fecal-coliform bacteria during this study. The fecal-coliform group of bacteria includes bacteria that can indicate contamination from humans, livestock, pets, and wildlife, but also can include bacteria from non-enteric sources (U.S. Environmental Protection Agency, 1986). The median concentrations in samples collected during the study were $22 \mathrm{CFU} / 100 \mathrm{~mL}$ at the Headworks site, $24 \mathrm{CFU} / 100 \mathrm{~mL}$ at the Inflow site, and $320 \mathrm{CFU} / 100 \mathrm{~mL}$ at the Tailrace site. Measurements of fecal-coliform bacteria made at all three sites during the study ranged from less than $1 \mathrm{CFU} / 100 \mathrm{~mL}$ in a sample from Headworks to $570 \mathrm{CFU} / 100 \mathrm{~mL}$ in a sample from Tailrace. The concentrations of fecal-coliform bacteria in samples from Tailrace did not meet the single-sample primary contact recreation criterion of $200 \mathrm{CFU} / 100 \mathrm{~mL}$ for freshwater (Washington State Department of Ecology, 2011) (table 8) on four occasions out of six (table 10). 
Table 10. Fecal-coliform bacteria in samples from Lake Tapps Diversion at Dieringer (Tailrace), Washington, July-December 2010.

[C riterion is the single-sample level for primary contact recreation (Washington State Department of Ecology, 2011). Abbreviations: $\mathrm{ft}^{3} / \mathrm{s}$, cubic foot per second; CFU/100 mLs, colony-forming units per 100 milliliters; e, estimate]

\begin{tabular}{ccccc}
\hline Date & Time & $\begin{array}{c}\text { Streamflow } \\
\left.\text { (ft } \mathbf{t}^{\mathbf{3}} \mathbf{s}\right)\end{array}$ & $\begin{array}{c}\text { Fecal-coliform } \\
\text { bacteria } \\
\text { (CFU/100 } \mathbf{~ m L s )}\end{array}$ & $\begin{array}{c}\text { Criterion } \\
\text { (CFU/100 mLs) }\end{array}$ \\
\hline $07-06-10$ & 0950 & e 0.63 & 570 & 200 \\
$07-20-10$ & 0840 & e 0.63 & e 430 & 200 \\
$08-03-10$ & 0830 & e 1.52 & 270 & 200 \\
$08-17-10$ & 0900 & e 0.88 & 370 & 200 \\
$11-16-10$ & 1040 & 109 & 2 & 200 \\
$12-07-10$ & 1040 & 107 & 10 & 200 \\
\hline
\end{tabular}

\section{Nutrients}

Water samples were collected and analyzed for concentrations of the nitrogen species ammonia, nitrite, nitrite-plus-nitrate, and total nitrogen. Samples submitted for analysis of ammonia, nitrite, and nitrite-plus-nitrate nitrogen were filtered, and samples for analysis of total nitrogen were filtered and unfiltered. The concentrations of ammonia generally were quite small ranging from less than $0.01 \mathrm{mg} / \mathrm{L}$ at all three sites to a maximum of $0.038 \mathrm{mg} / \mathrm{L}$ at the Tailrace site; median concentrations of ammonia were $0.012 \mathrm{mg} / \mathrm{L}$ at the Headworks and Inflow sites, and $0.025 \mathrm{mg} / \mathrm{L}$ at the Tailrace site (table 9). Nitrite was rarely detected in concentrations greater than the method detection level of $0.001 \mathrm{mg} / \mathrm{L}$ in samples from all three sites during the study. Median concentrations of nitrite-plus-nitrate nitrogen were $0.028 \mathrm{mg} / \mathrm{L}$ at Headworks, $0.015 \mathrm{mg} / \mathrm{L}$ at Inflow, and $0.024 \mathrm{mg} / \mathrm{L}$ at Tailrace. The concentrations of nitrite-plusnitrate nitrogen at all three sites during the study ranged from less than $0.008 \mathrm{mg} / \mathrm{L}$ to $0.084 \mathrm{mg} / \mathrm{L}$ (both at Tailrace). The concentrations of filtered total nitrogen at all three sites during the study ranged from less than $0.05 \mathrm{mg} / \mathrm{L}$ at Headworks to $0.35 \mathrm{mg} / \mathrm{L}$ at Inflow with median concentrations of $0.12 \mathrm{mg} / \mathrm{L}$ at Headworks, $0.14 \mathrm{mg} / \mathrm{L}$ at Inflow, and $0.24 \mathrm{mg} / \mathrm{L}$ at Tailrace. Median concentrations of unfiltered total nitrogen were $0.06 \mathrm{mg} / \mathrm{L}$ at Headworks, $0.2 \mathrm{mg} / \mathrm{L}$ at Inflow, and $0.31 \mathrm{mg} / \mathrm{L}$ at Tailrace. The concentrations of unfiltered total nitrogen at all three sites during the study ranged from less than $0.05 \mathrm{mg} / \mathrm{L}$ at Headworks to $0.71 \mathrm{mg} / \mathrm{L}$ at Inflow.

Analyses of the phosphorus forms included orthophosphate (also referred to as soluble reactive phosphorus), filtered phosphorus, and unfiltered phosphorus (also referred to as total phosphorus). Median concentrations of orthophosphate were $0.017 \mathrm{mg} / \mathrm{L}$ at Headworks, $0.005 \mathrm{mg} / \mathrm{L}$ at Inflow, and $0.02 \mathrm{mg} / \mathrm{L}$ at Tailrace. Concentrations of orthophosphate in samples from all three sites during the study ranged from less than 0.004 to $0.032 \mathrm{mg} / \mathrm{L}$ (both at Tailrace). Median concentrations of filtered phosphorus were $0.013 \mathrm{mg} / \mathrm{L}$ at Headworks, $0.005 \mathrm{mg} / \mathrm{L}$ at Inflow, and $0.016 \mathrm{mg} / \mathrm{L}$ at Tailrace. Concentrations of filtered phosphorus in samples from all three sites during the study ranged from less than 0.003 to $0.029 \mathrm{mg} / \mathrm{L}$ (both at Tailrace). Median concentrations of unfiltered phosphorus were $0.382 \mathrm{mg} / \mathrm{L}$ at Headworks, $0.089 \mathrm{mg} / \mathrm{L}$ at Inflow, and $0.068 \mathrm{mg} / \mathrm{L}$ at Tailrace. Concentrations of unfiltered phosphorus in samples from all three sites during the study ranged from $0.008 \mathrm{mg} / \mathrm{L}$ at Tailrace to $0.492 \mathrm{mg} / \mathrm{L}$ at Headworks.

\section{Quality of Water in the White River and Lake Tapps Diversion (Tailrace)- Continuous Monitoring}

Multiparameter water-quality sondes installed at three sites (table 1) were fully operational by late May 2010. The White River at R Street (R-Street) is missing several weeks of data during June while the deployment was being optimized for high flows, and during mid-December when the sonde was removed because of debris during high flows. The Headworks site also is missing some record during December when flows were altered at the diversion dam and the sonde was out of water.

Even though the source of the White River is from glaciers on Mount Rainier, the water temperature of the White River is moderated somewhat by residence time upstream of the Mud Mountain Dam. Continuous measurements of water temperature were used to calculate the 7-day average of daily maximum temperatures (7-DADMax) by averaging the maximum for a day with the daily maximum of the 3 days prior and the 3 days after that date (appendix E). The 7-DADMax at the Headworks site ranged from $2.6^{\circ} \mathrm{C}$ on November 25, 2010, to $16.5^{\circ} \mathrm{C}$ on August 14-15, 2010 (fig. 9). 


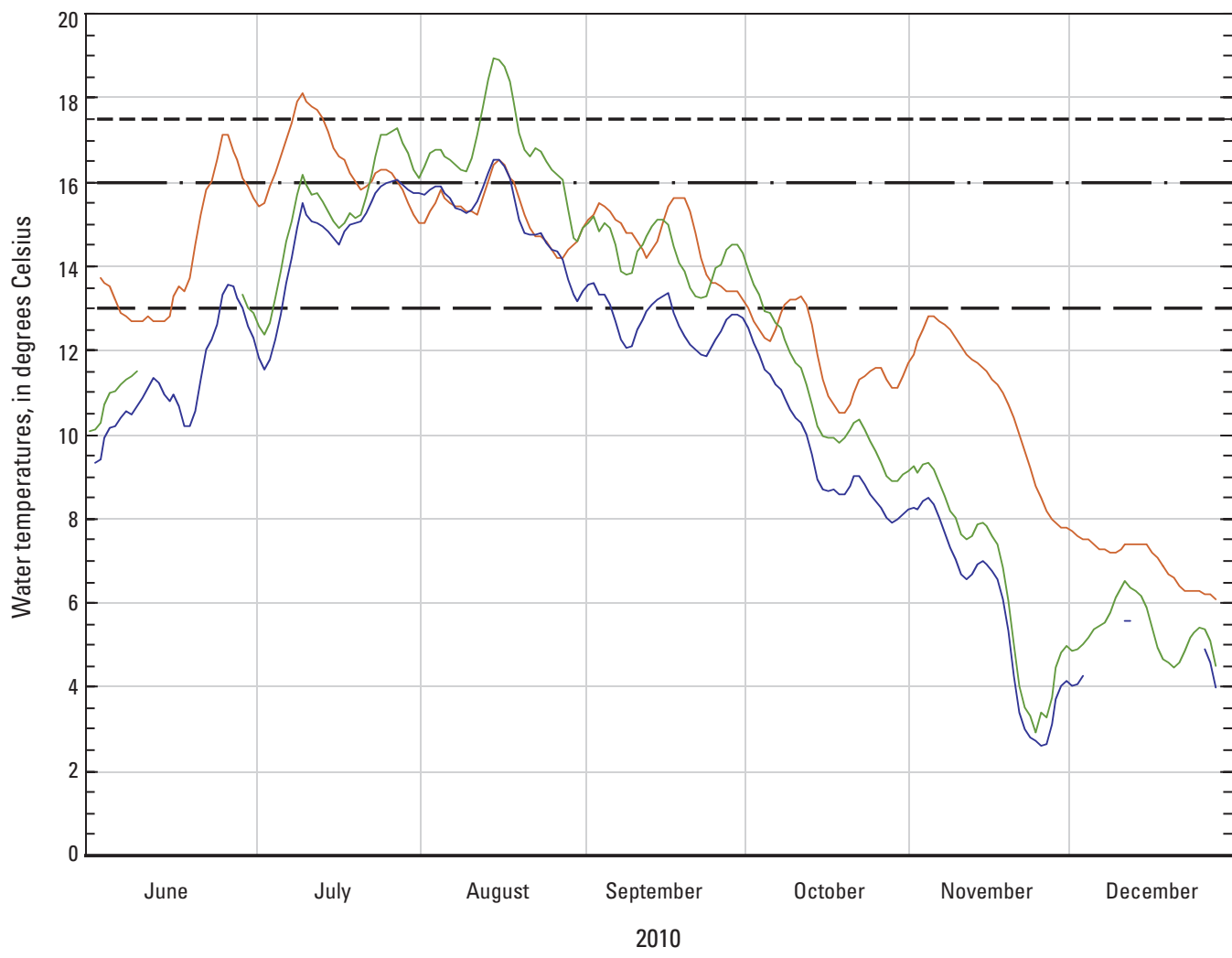

EXPLANATION

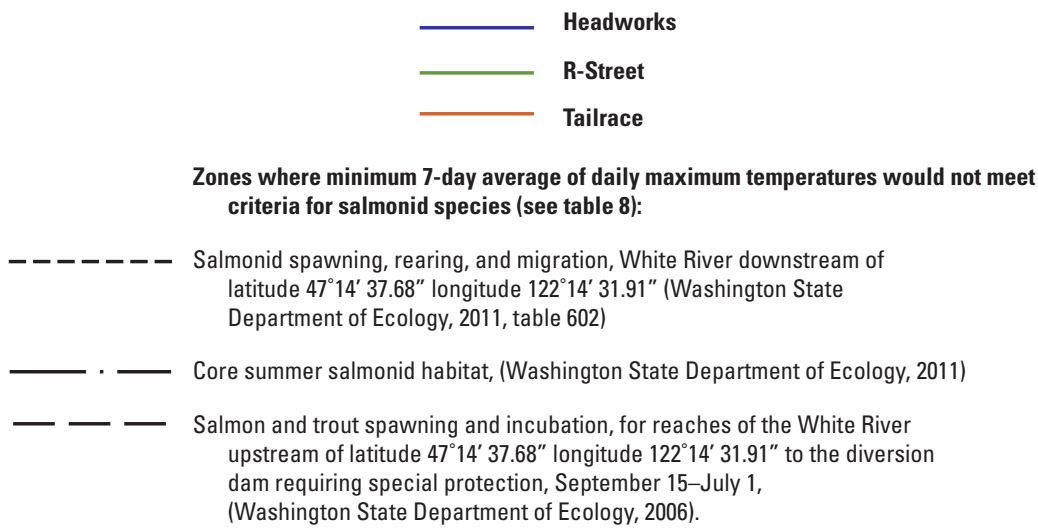

Figure 9. Seven-day average of daily maximum water temperatures at White River at the Headworks, White River at R Street, and Lake Tapps Diversion at Dieringer (Tailrace), Washington, May-December 2010. 
The 7-DADMax at the R-Street site ranged from $2.9^{\circ} \mathrm{C}$ on November 24, 2010, to $18.9^{\circ} \mathrm{C}$ on August 14-15, 2010 (ig. 9). The 7-DADMax at the Tailrace site ranged from $6.1^{\circ} \mathrm{C}$ on December 28, 2010, to $18.1^{\circ} \mathrm{C}$ on July 9, 2010 (fig. 9).

The White River is well-oxygenated with concentrations of dissolved oxygen at the Headworks site ranging from a minimum of $9.2 \mathrm{mg} / \mathrm{L}$ on August 5, 14, and 16, 2010, to a maximum during the study of $14.4 \mathrm{mg} / \mathrm{L}$ on December 31, 2010 (fig. 10). Dissolved oxygen at the Tailrace site, however, was affected by reduced flow during the study and concentrations ranged from a minimum of $0.7 \mathrm{mg} / \mathrm{L}$ on August 9, 2010, to a maximum during the study of $22.0 \mathrm{mg} / \mathrm{L}$ on July 8, 2010 (fig. 11). The concentrations of dissolved oxygen at the R-Street site ranged from a minimum of $9.4 \mathrm{mg} / \mathrm{L}$ on August 16-17, 2010, to a maximum of $15.0 \mathrm{mg} / \mathrm{L}$ on November 23-24 (U.S. Geological Survey, 2011c).

The continuous measurements of $\mathrm{pH}$ at the Headworks site ranged from a low of $6.9 \mathrm{pH}$ units measured on December 13, 2010, to a maximum during the study of $8.6 \mathrm{pH}$ units measured on July 28, 2010. Measurements of pH at the R-Street site ranged from $6.8 \mathrm{pH}$ units on December 13-15, 2010, to a maximum of $7.4 \mathrm{pH}$ units on July 24, 28, and 30, 2010. Measurements of $\mathrm{pH}$ at the Tailrace site ranged from $6.4 \mathrm{pH}$ units on September 28, 2010, to a maximum of $9.4 \mathrm{pH}$ units on September 14, 2010.

Specific conductance generally was low, reflecting the relatively dilute chemical composition of the water. Specific conductance at the Headworks site ranged from a minimum of $39 \mu \mathrm{S} / \mathrm{cm}$ on December 13, 2010, to a maximum of $84 \mu \mathrm{S} / \mathrm{cm}$ on October 15-17, 2010. Specific conductance at the R-Street site ranged from a minimum of $45 \mu \mathrm{S} / \mathrm{cm}$ on July 12, 2010, to a maximum of $87 \mu \mathrm{S} / \mathrm{cm}$ on October $7,21-24$, and November 26, 2010. Specific conductance at the Tailrace site ranged from a minimum of $53 \mu \mathrm{S} / \mathrm{cm}$ on December 31, 2010, to a maximum of 2,270 $\mu \mathrm{S} / \mathrm{cm}$ on September 28, 2010. Spikes in specific conductance at the Tailrace on August 31 and September 10, 2010, may be related to storm-water runoff from pipes discharging near the sonde sensors. The maximum

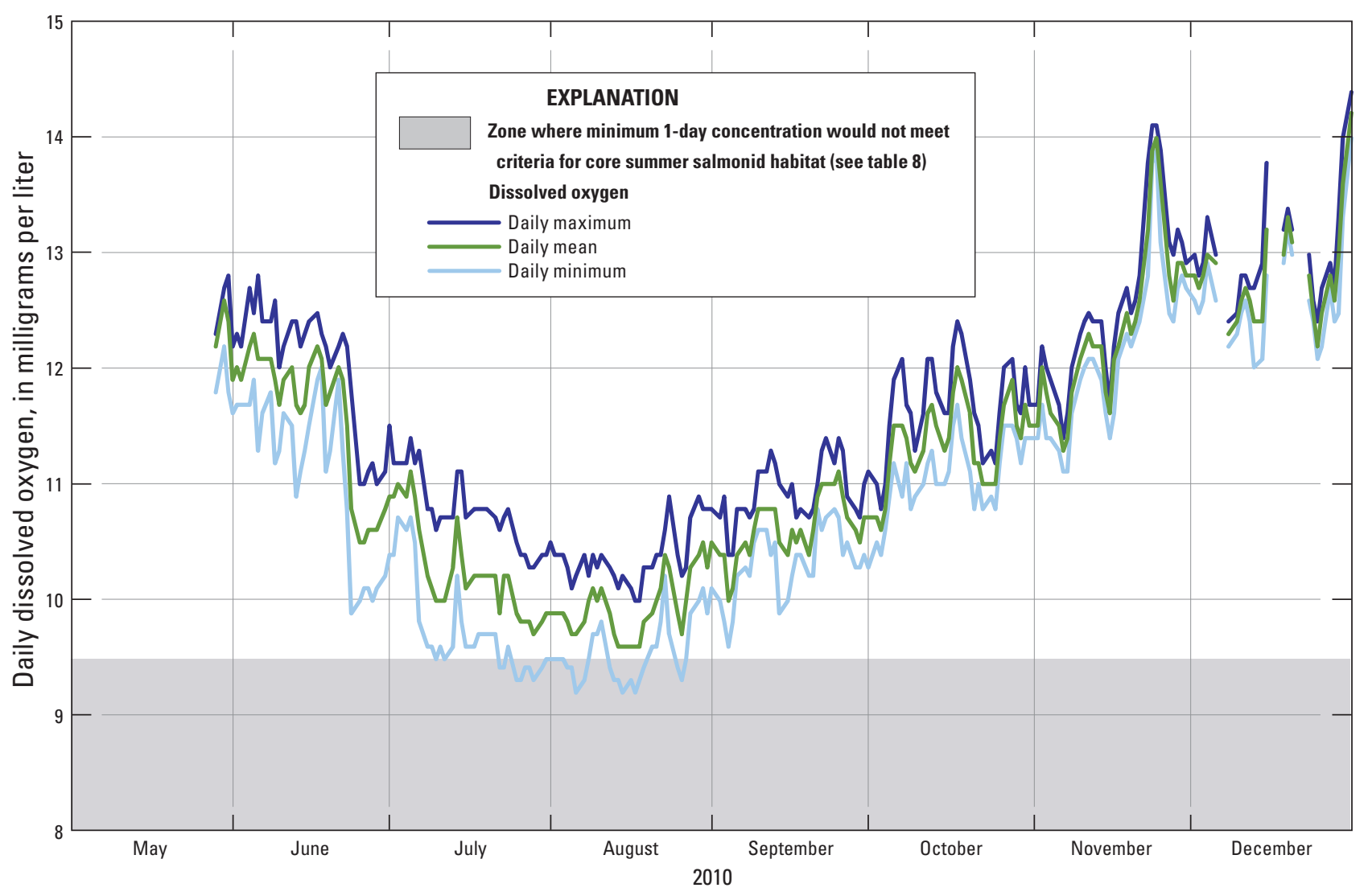

Figure 10. Minimum, maximum, and mean dissolved oxygen concentrations at White River at Headworks, Washington, May-December 2010. 
value of 2,270 $\mu \mathrm{S} / \mathrm{cm}$ recorded on August 31 followed a rain event of $0.15 \mathrm{in}$. over a 24-hour period recorded at the McMillin Reservoir rain gage (fig. 1). The sources of the runoff and the dissolved materials driving these high conductivity spikes are unknown. When water is released from the lake, specific conductance generally is less than about $70 \mu \mathrm{S} / \mathrm{cm}$ and similar to the lake water at the Lake Outlet site. The specific conductance values of about $140 \mu \mathrm{S} / \mathrm{cm}$ occurred during periods of no water releases from the lake and likely reflect the input of subsurface water, which typically carries higher content of dissolved solids than surface water.

The quality of physical properties and concentrations in water measured continuously at the three sites (Headworks, R-Street, and Tailrace) generally was good and met the freshwater criteria designated by the Washington State Department of Ecology (2006, 2011) for recreational uses and aquatic life uses, with several exceptions. The 7-DADMax temperatures exceeded the freshwater aquatic life criterion of $16^{\circ} \mathrm{C}$ for core summer salmonid habitat (table 8; Washington State Department of Ecology, 2011) on 6 days at the Headworks site and 37 days at the R-Street site. A higher criterion of $17.5^{\circ} \mathrm{C}$ for salmonid spawning, rearing, and migration applies to the White River from the mouth to latitude $47^{\circ} 14^{\prime} 37.68^{\prime \prime}$ longitude $122^{\circ} 14^{\prime} 31.91 "$ upstream of RM 3.6 and the Tailrace (Washington State Department of Ecology, 2011), and 7-DADMax temperatures exceeded this criterion on 5 days at the Tailrace site. A lower criterion of $13^{\circ} \mathrm{C}$ for salmon and trout spawning and incubation applies to reaches of the White River upstream of latitude $47^{\circ} 14^{\prime} 37.68^{\prime \prime}$ longitude $122^{\circ} 14^{\prime} 31.91 "$ to the Diversion Dam (excluding portions within the Muckleshoot Indian Reservation) from September 15 to July 1 (Washington State Department of Ecology, 2006). This lower criterion of $13^{\circ} \mathrm{C}$ was exceeded by 7-DADMax temperatures on 6 days at the Headworks site and on 20 days at the R-Street site (fig. 9).

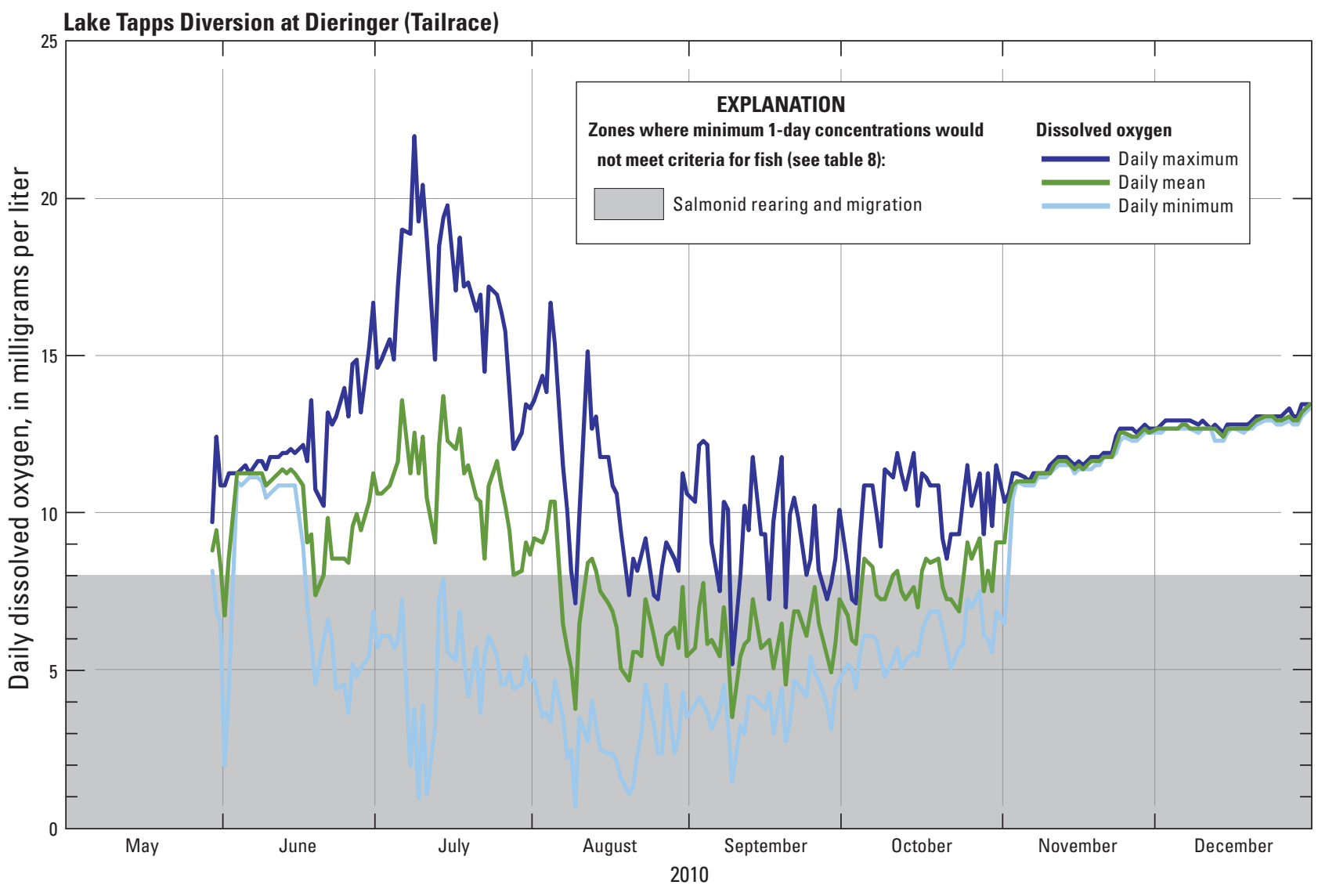

Figure 11. Minimum, maximum, and mean disolved oxygen at Lake Tapps Diversion at Dieringer (Tailrace), Washington, May-December 2010. 
The freshwater aquatic life dissolved oxygen criterion of $9.5 \mathrm{mg} / \mathrm{L}$ for core summer salmonid habitat (table 8; Washington State Department of Ecology, 2011) was not met at the Headworks site for several weeks during July and August 2010 (fig. 10) and at the R-Street site on August 16-17, 2010. The 1-day minimum dissolved oxygen criterion of $8.0 \mathrm{mg} / \mathrm{L}$ for salmonid spawning, rearing, and migration occasionally was not met at the Tailrace site in June and frequently was not met during May-November 2010 (fig. 11). However, the dissolved oxygen criteria require that measurements should not be taken from shallow stagnant backwater areas, but reduced flow in the Tailrace frequently created such environments.

Exceptions for measurements of $\mathrm{pH}$ greater than the freshwater aquatic-life upper limit of $8.5 \mathrm{pH}$ units occurred at the Headworks site during July 2010 (fig. 12). Aquatic life criteria for $\mathrm{pH}$ also were not met at the Tailrace site during June, July, and August 2010, when $\mathrm{pH}$ values were greater than $8.5 \mathrm{pH}$ units (ig. 13) and briefly in August when daily minimum $\mathrm{pH}$ values decreased to less than $6.5 \mathrm{pH}$ units.

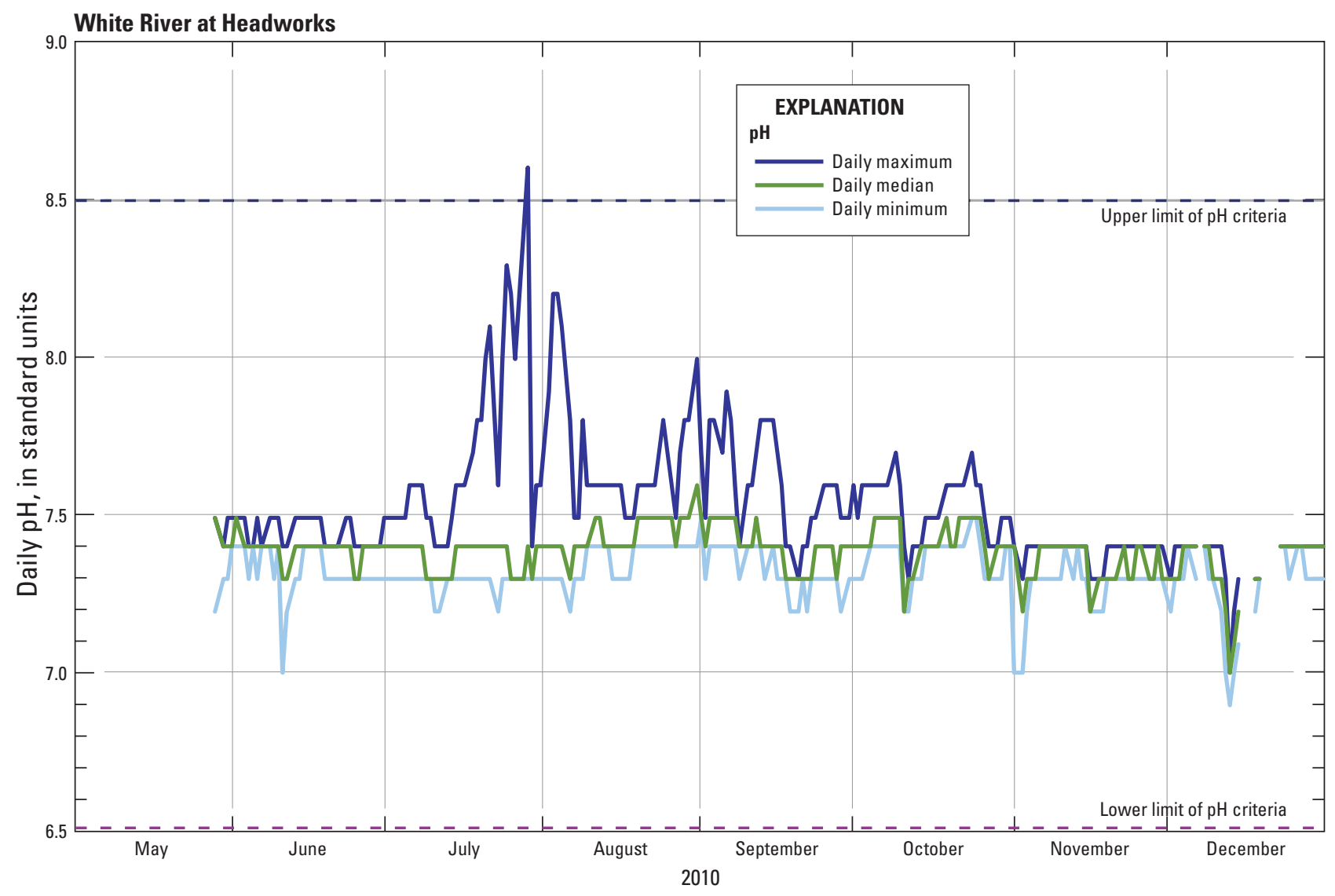

Figure 12. Minimum, maximum, and median pH at White River at Headworks, Washington, May-December 2010. 


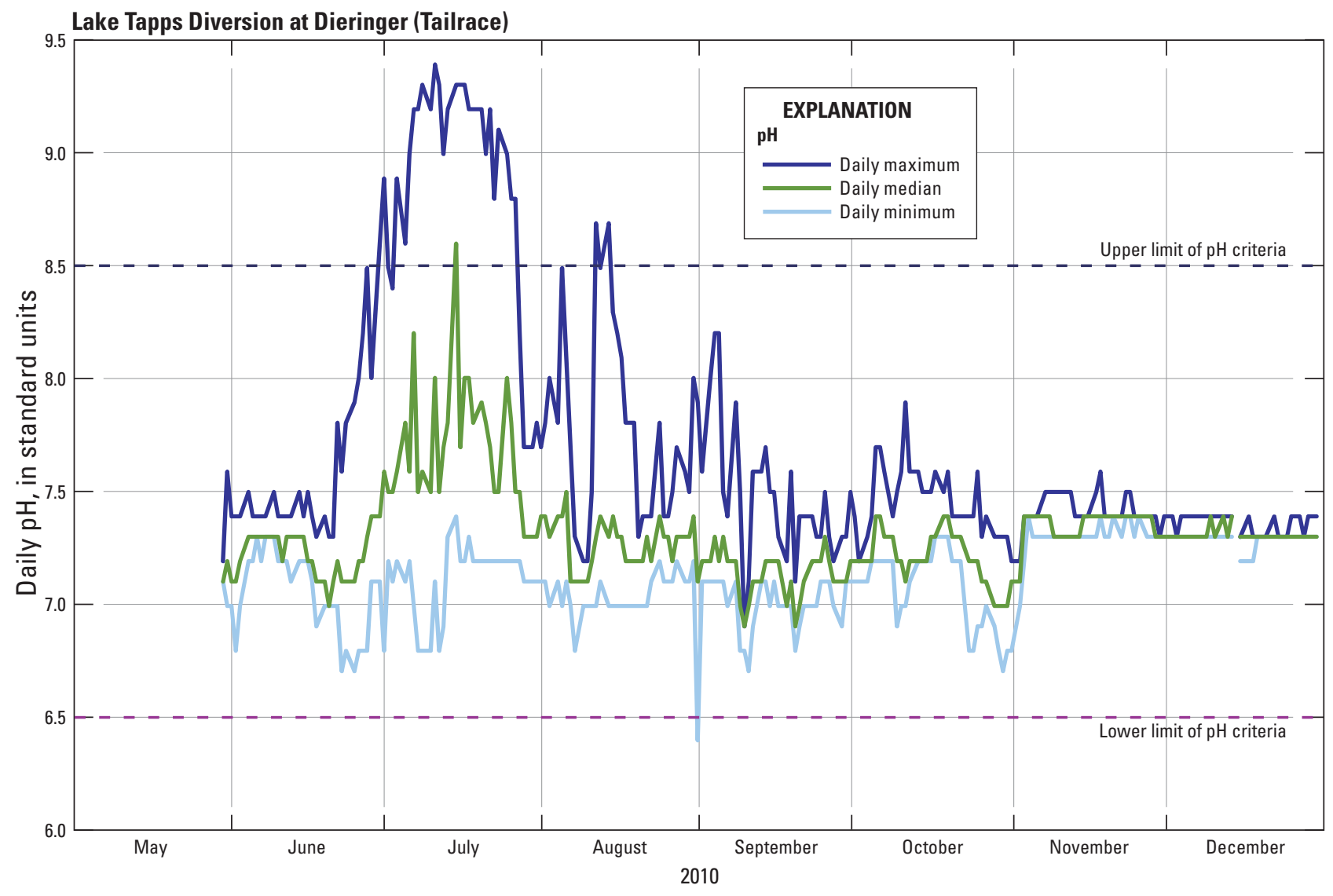

Figure 13. Minimum, maximum, and median $\mathrm{pH}$ at Lake Tapps Diversion at Dieringer (Tailrace), Washington, May-December 2010. 


\section{Quality of Water in Lake Tapps}

This section presents field observations noted during the lake sampling events and the results of laboratory analyses for chemical and biological constituents. Field observations recorded during sampling included weather conditions, the extent of human or bird activity near the sampling location, total depth of water at the sampling location, and profiles of physical properties with depth. Results presented include the inorganic and organic chemical analyses performed at the NWQL and Test America Laboratory, and the turbidity and fecal-coliform analyses performed by project staff at the FSU.

\section{Physical Properties and Profiles}

In general, the epilimnion (or near surface) water of Lake Tapps was relatively clear as indicated by low median turbidity values of less than about 1.6 NTRU and relatively high median Secchi disk transparencies of $4.9 \mathrm{~m}$ or more (table 11). The clearest water of the nine sites as measured by Secchi disk, was at the Deep site with a median Secchi disk measurement of $6.05 \mathrm{~m}$, and at the Lake Outlet site with a median of $5.80 \mathrm{~m}$. The Secchi disk measurements at the Deep site represent a 2 to 6-fold increase in transparency depths from historical measurements at this location during 1974-1997 (Bortleson and others, 1976; Sumioka and Dion, 1985; Smith and others, 2000). However, at the Allan Yorke, Lake Inlet, and Southeast Arm sites, the water was more turbid and less transparent than the other six sites with median turbidities as high as 3.04 NTRU and median Secchi disk transparencies of $2.61 \mathrm{~m}$ or less.

Water of the epilimnion at all sites generally was warm, yet well oxygenated. Median water temperatures were from 18.2 to $18.9^{\circ} \mathrm{C}$ and maximums ranged from 22.9 to $25.0^{\circ} \mathrm{C}$ (table 11). At sites where total water depth was equal to or greater than $15 \mathrm{~m}$, median water temperatures in the hypolimnion (or near the bottom) ranged from $9.2^{\circ} \mathrm{C}$ at the Deep site to $10.7^{\circ} \mathrm{C}$ at Snag Island and $12.0^{\circ} \mathrm{C}$ at Tapps Island sites (table 11). At shallow sites (5 m or less) (Allan Yorke, Lake Inlet, Southeast Arm, and Dike 2B), hypolimnion temperatures were similar to those of the epilimnion or only a few tenths of a degree cooler (table 11, fig. 14). Median dissolved oxygen concentrations in the epilimnion were $8.42 \mathrm{mg} / \mathrm{L}$ or greater. Minimum concentrations were not less than $7.4 \mathrm{mg} / \mathrm{L}$ except at the Snag Island and Lake Inlet sites with minimums of 6.5 and $6.9 \mathrm{mg} / \mathrm{L}$, respectively (table 11). At the deep sites (Deep, Tapps Island, and Snag Island), the hypolimnion became anoxic with dissolved oxygen concentrations of less than about $0.1 \mathrm{mg} / \mathrm{L}$ (fig. 15). The hypolimnion of the shallow sites, except at the Lake Inlet site, remained oxygenated during the study with at least $6.3 \mathrm{mg} / \mathrm{L}$ dissolved oxygen; at the Lake Inlet site, dissolved oxygen reached a low of $1.4 \mathrm{mg} / \mathrm{L}$.

On the basis of $\mathrm{pH}$ and specific conductance measurements, Lake Tapps water is $\mathrm{pH}$ neutral and chemically dilute. For the most part, median $\mathrm{pH}$ values from the epilimnion and hypolimnion were within a relatively neutral range of 6.84 to $7.64 \mathrm{pH}$ units, and maximum $\mathrm{pH}$ values did not exceed $7.8 \mathrm{pH}$ units at any site during the study (table 11, fig. 16). At most of the sites, median specific conductance for the epilimnion and the hypolimnion was less than $70 \mu \mathrm{S} / \mathrm{cm}$ (table 11). These low magnitudes of specific conductance indicate a generally dilute type of water with low concentrations of dissolved solids. The highest specific conductance values and the greatest variability in the measurements were observed in the hypolimnion water of the Deep and Snag Island sites with medians of 73 and $88 \mu \mathrm{S} / \mathrm{cm}$, respectively, and maximums of 120 and $126 \mu \mathrm{S} / \mathrm{cm}$, respectively (fig. 17). 
Table 11. Summary statistics of water-quality properties and concentrations of nutrients, total suspended solids, fecal-coliform bacteria, and chlorophyll a for nine Lake Tapps study sites, Washington, July-December 2010.

[Statistics calculated with censoring levels set to a common level for each constituent, which entailed using water year 2011 method detection limits to match 2010 laboratory reporting levels and are not rounded to standard USGS significant figures. Abbreviations: CFU/100 mL, colony forming units per 100 milliliters; mg/L, milligram per liter; $\mu \mathrm{S} / \mathrm{cm}$, microsiemens per centimeter at $25^{\circ} \mathrm{C}$; ${ }^{\circ} \mathrm{C}$, degrees Celsius; e, estimated; m, meter; $\mu \mathrm{g} / \mathrm{L}$, microgram per liter; NTRU, nephelometric turbidity ratio units; ND, no detections greater than method detection level; <, less than; -, no data or not applicable]

\begin{tabular}{|c|c|c|c|c|c|c|c|c|}
\hline \multirow[t]{2}{*}{ Site } & \multirow[t]{2}{*}{ Statistic } & \multicolumn{2}{|c|}{$\begin{array}{c}\text { Turbidity } \\
\text { (NTRU) }\end{array}$} & \multirow{2}{*}{$\begin{array}{c}\begin{array}{c}\text { Secchi } \\
\text { transparency } \\
\text { depth }(\mathrm{m})\end{array} \\
\text { Epilimnion }\end{array}$} & \multirow{2}{*}{\multicolumn{2}{|c|}{$\begin{array}{c}\begin{array}{c}\text { Water } \\
\text { temperature } \\
\left({ }^{\circ} \mathrm{C}\right)\end{array} \\
\text { Epilimnion Hypolimnion }\end{array}$}} & \multicolumn{2}{|c|}{$\begin{array}{c}\text { Dissolved } \\
\text { oxygen } \\
\text { (mg/L) }\end{array}$} \\
\hline & & Epilimnion & Hypolimnion & & & & Epilimnion & Hypolimnion \\
\hline \multirow[t]{3}{*}{ Deep } & Median & 0.85 & 3.86 & 6.05 & 18.2 & 9.2 & 8.42 & 0.34 \\
\hline & Mean & 1.19 & 9.03 & 5.38 & 16.8 & 9.1 & 8.53 & 2.36 \\
\hline & Range & $0.6-2.7$ & $0.9-42$ & 2.09-8.09 & $6.8-23.8$ & $6.4-11.0$ & $7.4-10.1$ & $0.1-10.4$ \\
\hline \multirow[t]{3}{*}{ Allan Yorke } & Median & 1.68 & 2.23 & 2.61 & 18.4 & 18.0 & 8.78 & 8.48 \\
\hline & Mean & 1.94 & 2.64 & 2.57 & 16.8 & 16.1 & 9.26 & 8.41 \\
\hline & Range & 1.3-3.6 & $1.3-5.7$ & $1.62-3.22$ & $4.8-24.2$ & $4.8-22.0$ & $8.2-12.6$ & 6.3-12.6 \\
\hline \multirow[t]{3}{*}{ Northeast Arm } & Median & 0.94 & 1.58 & 4.94 & 18.8 & 15.4 & 8.64 & 4.52 \\
\hline & Mean & 1.20 & 2.18 & 4.69 & 17.2 & 14.4 & 8.84 & 5.37 \\
\hline & Range & $0.5-3.3$ & $0.9-4.2$ & $1.62-6.29$ & $6.3-24.0$ & $6.2-18.4$ & $7.8-10.9$ & $0.8-10.9$ \\
\hline \multirow[t]{3}{*}{ Tapps Island } & Median & 1.55 & 2.07 & 5.26 & 18.4 & 12.0 & 8.71 & 0.54 \\
\hline & Mean & 1.28 & 2.11 & 5.00 & 16.9 & 11.7 & 8.87 & 3.41 \\
\hline & Range & $0.6-1.8$ & $1.2-3.7$ & $3.34-6.94$ & $6.4-23.2$ & $6.3-14.5$ & 7.8-10.9 & $0.1-10.9$ \\
\hline \multirow[t]{3}{*}{ Snag Island } & Median & 1.17 & 5.37 & 4.87 & 18.3 & 10.7 & 8.45 & 0.19 \\
\hline & Mean & 1.76 & 5.15 & 4.68 & 16.8 & 10.5 & 8.54 & 3.05 \\
\hline & Range & $0.6-6.0$ & $1.4-9.2$ & 2.69-7.14 & $6.2-23.5$ & $6.2-12.8$ & $6.5-10.9$ & $0.1-10.9$ \\
\hline \multirow[t]{3}{*}{ Lake Inlet } & Median & 1.67 & 2.15 & 2.54 & 18.9 & 18.1 & 8.68 & 8.11 \\
\hline & Mean & 1.82 & 2.09 & 2.58 & 17.4 & 16.2 & 8.90 & 6.78 \\
\hline & Range & $1.1-3.1$ & $1.2-3.1$ & $1.82-3.39$ & $5.3-24.9$ & 5.3-21.3 & $6.9-11.6$ & $1.4-11.6$ \\
\hline \multirow[t]{3}{*}{ Southeast Arm } & Median & 3.04 & 3.56 & 1.63 & 18.5 & 18.3 & 8.77 & 8.34 \\
\hline & Mean & 2.68 & 4.03 & 1.80 & 17.1 & 16.6 & 9.22 & 8.66 \\
\hline & Range & $1.1-3.9$ & $1.3-11$ & $1.40-2.54$ & $4.6-25.0$ & 4.6-23.6 & $8.1-12.4$ & $6.6-12.4$ \\
\hline \multirow[t]{3}{*}{ Lake Outlet } & Median & 0.72 & 1.22 & 5.80 & 18.2 & 14.8 & 8.72 & 8.26 \\
\hline & Mean & 1.12 & 1.40 & 5.67 & 16.8 & 14.1 & 8.81 & 7.01 \\
\hline & Range & $0.5-3.0$ & $0.7-3.2$ & 2.33-8.24 & $6.8-22.9$ & $6.8-17.6$ & $7.8-9.9$ & $2.8-9.88$ \\
\hline \multirow[t]{3}{*}{ Dike 2B } & Median & 0.70 & 0.87 & 4.93 & 18.4 & 17.9 & 8.84 & 8.89 \\
\hline & Mean & 1.21 & 1.29 & 4.25 & 16.8 & 16.7 & 8.92 & 9.06 \\
\hline & Range & $0.6-2.9$ & $0.5-2.7$ & $1.91-5.77$ & $6.9-23.0$ & $6.9-22.9$ & 8.0-10.3 & $8.4-10.3$ \\
\hline
\end{tabular}


Table 11. Summary statistics of water-quality properties and concentrations of nutrients, total suspended solids, fecal-coliform bacteria, and chlorophyll a for nine Lake Tapps study sites, Washington, July-December 2010._Continued

[Statistics calculated with censoring levels set to a common level for each constituent, which entailed using water year 2011 method detection limits to match 2010 laboratory reporting levels and are not rounded to standard USGS significant figures. Abbreviations: CFU/100 mL, colony forming units per 100 milliliters; mg/L, milligrams per liter; $\mu \mathrm{S} / \mathrm{cm}$, microsiemens per centimeter at $25^{\circ} \mathrm{C}$; ${ }^{\circ} \mathrm{C}$, degrees Celsius; e, estimated; m, meters; $\mu$ g/L, micrograms per liter; NTRU, nephelometric turbidity ratio units; ND, no detections greater than method detection level; <, less than; -, no data or not applicable]

\begin{tabular}{|c|c|c|c|c|c|c|c|c|}
\hline \multirow[b]{2}{*}{ Site } & \multirow[b]{2}{*}{ Statistic } & \multicolumn{2}{|c|}{$\begin{array}{c}\mathrm{pH} \\
\text { (standard } \\
\text { units) }\end{array}$} & \multicolumn{2}{|c|}{$\begin{array}{c}\text { Specific } \\
\text { conductance } \\
(\mu \mathrm{S} / \mathrm{cm})\end{array}$} & \multicolumn{2}{|c|}{$\begin{array}{c}\text { Total } \\
\text { suspended } \\
\text { solids } \\
\text { (mg/L) }\end{array}$} & \multirow{2}{*}{$\begin{array}{c}\begin{array}{c}\text { Fecal } \\
\text { coliform } \\
\text { bacteria } \\
\text { (CFU/100 mL) }\end{array} \\
\text { Epilimnion }\end{array}$} \\
\hline & & Epilimnion & Hypolimnion & Epilimnion & Hypolimnion & Epilimnion & Hypolimnion & \\
\hline \multirow[t]{3}{*}{ Deep } & Median & 7.60 & 6.84 & 67 & 73 & $<1.1$ & e2.40 & $<1$ \\
\hline & Mean & 7.54 & 6.93 & 66 & 77 & e1.80 & 5.65 & 14 \\
\hline & Range & $7.3-7.7$ & $6.6-7.4$ & $65-67$ & $67-120$ & $<1.1-3.6$ & $<1.1-30$ & $<1-68$ \\
\hline \multirow[t]{3}{*}{ Allan Yorke } & Median & 7.62 & 7.63 & 68 & 68 & e1.80 & e3.0 & 4 \\
\hline & Mean & 7.61 & 7.60 & 69 & 68 & 2.05 & e3.0 & 5 \\
\hline & Range & $7.4-7.8$ & $7.4-7.8$ & $68-73$ & $64-73$ & $<1.1-5.2$ & $<1.1-6.0$ & $2-14$ \\
\hline \multirow[t]{3}{*}{ Northeast Arm } & Median & 7.52 & 7.42 & 66 & 69 & $<1.1$ & $<1.1$ & $<1$ \\
\hline & Mean & 7.53 & 7.44 & 66 & 69 & $<1.1$ & e1.57 & 1 \\
\hline & Range & $7.4-7.7$ & 7.3-7.6 & $64-67$ & $65-72$ & $<1.1-\mathrm{e} 2.0$ & $<1.1-6.8$ & $<1-3$ \\
\hline \multirow[t]{3}{*}{ Tapps Island } & Median & 7.58 & 7.17 & 66 & 68 & $<1.1$ & e1.80 & 2 \\
\hline & Mean & 7.57 & 7.20 & 66 & 68 & $<1.1$ & e1.94 & 3 \\
\hline & Range & $7.4-7.7$ & $6.8-7.5$ & $64-67$ & $66-72$ & $<1.1-\mathrm{e} 1.6$ & $<1.1-\mathrm{e} 3.6$ & $<1-12$ \\
\hline \multirow[t]{3}{*}{ Snag Island } & Median & 7.49 & 6.94 & 67 & 88 & $<1.1$ & 4.0 & 1 \\
\hline & Mean & 7.50 & 7.06 & 67 & 91 & $<1.1$ & 4.25 & 2 \\
\hline & Range & 7.3-7.6 & $6.7-7.5$ & $64-69$ & $66-126$ & <1.1-e1.6 & $<1.1-7.6$ & $<1-13$ \\
\hline \multirow[t]{3}{*}{ Lake Inlet } & Median & 7.50 & 7.48 & 67 & 68 & e2.00 & e2.80 & 1 \\
\hline & Mean & 7.52 & 7.48 & 67 & 69 & e2.55 & e2.83 & 1 \\
\hline & Range & $7.3-7.7$ & 7.3-7.6 & 66-69 & $66-77$ & $<1.1-4.0$ & $<1.1-4.4$ & $<1-5$ \\
\hline \multirow[t]{3}{*}{ Southeast Arm } & Median & 7.52 & 7.50 & 67 & 68 & e3.60 & e3.80 & 1 \\
\hline & Mean & 7.53 & 7.52 & 67 & 68 & e3.12 & 5.09 & 1 \\
\hline & Range & $7.4-7.7$ & $7.4-7.6$ & $65-69$ & $65-71$ & $<1.1-5.2$ & $<1.1-14$ & $<1-4$ \\
\hline \multirow[t]{3}{*}{ Lake Outlet } & Median & 7.52 & 7.45 & 66 & 66 & $<1.1$ & $<1.1$ & 4 \\
\hline & Mean & 7.50 & 7.44 & 66 & 67 & $<1.1$ & 1.33 & 10 \\
\hline & Range & 7.4-7.6 & 7.4-7.6 & $64-68$ & $66-69$ & $<1.1-\mathrm{e} 2.4$ & $<1.1-3.6$ & $1-54$ \\
\hline \multirow[t]{3}{*}{ Dike 2B } & Median & 7.64 & 7.64 & 66 & 66 & $<1.1$ & $<1.1$ & 2 \\
\hline & Mean & 7.60 & 7.60 & 66 & 66 & $<1.1$ & $<1.1$ & 5 \\
\hline & Range & $7.4-7.8$ & $7.4-7.7$ & $65-67$ & $65-67$ & $<1.1-\mathrm{e} 1.2$ & $<1.1-\mathrm{e} 1.2$ & $<1-16$ \\
\hline
\end{tabular}


Table 11. Summary statistics of water-quality properties and concentrations of nutrients, total suspended solids, fecal-coliform bacteria, and chlorophyll a for nine Lake Tapps study sites, Washington, July-December 2010. - Continued

[Statistics calculated with censoring levels set to a common level for each constituent, which entailed using water year 2011 method detection limits to match 2010 laboratory reporting levels and are not rounded to standard USGS significant figures. Abbreviations: CFU/100 mL, colony forming units per 100 milliliters; mg/L, milligram per liter; $\mu \mathrm{S} / \mathrm{cm}$, microsiemens per centimeter at $25^{\circ} \mathrm{C}$; ${ }^{\circ} \mathrm{C}$, degrees Celsius; e, estimated; m, meters; $\mu \mathrm{g} / \mathrm{L}$, microgram per liter; NTRU, nephelometric turbidity ratio units; ND, no detections above method detection level; <, less than; -, no data or not applicable]

\begin{tabular}{|c|c|c|c|c|c|c|c|}
\hline \multirow[b]{2}{*}{ Site } & \multirow[b]{2}{*}{ Statistic } & \multicolumn{2}{|c|}{$\begin{array}{c}\text { Ammonia } \\
\text { nitrogen } \\
\text { (mg/L) }\end{array}$} & \multicolumn{2}{|c|}{$\begin{array}{c}\text { Nitrite } \\
\text { nitrogen } \\
\text { (mg/L) }\end{array}$} & \multicolumn{2}{|c|}{$\begin{array}{l}\text { Nitrite plus } \\
\text { nitrate } \\
\text { nitrogen } \\
\text { (mg/L) }\end{array}$} \\
\hline & & Epilimnion & Hypolimnion & Epilimnion & Hypolimnion & Epilimnion & Hypolimnion \\
\hline \multirow[t]{3}{*}{ Deep } & Median & 0.008 & 0.024 & ND & $<0.001$ & $<0.008$ & 0.073 \\
\hline & Mean & 0.011 & 0.076 & - & $<0.001$ & 0.01 & 0.1 \\
\hline & Range & $<0.01-0.029$ & $<0.01-0.51$ & - & $<0.001-0.002$ & $<0.008-0.028$ & $<0.008-0.253$ \\
\hline \multirow[t]{3}{*}{ Allan Yorke } & Median & ND & $<0.01$ & $<0.001$ & 0.001 & $<0.008$ & $<0.008$ \\
\hline & Mean & - & 0.011 & $<0.001$ & $<0.001$ & $<0.008$ & $<0.008$ \\
\hline & Range & & $<0.01-0.022$ & $<0.001-0.001$ & $<0.001-0.001$ & $<0.008-0.039$ & $<0.008-0.04$ \\
\hline \multirow[t]{3}{*}{ Northeast Arm } & Median & 0.01 & 0.018 & $<0.001$ & $<0.001$ & $<0.008$ & $<0.008$ \\
\hline & Mean & 0.013 & 0.019 & $<0.001$ & 0.001 & 0.009 & 0.009 \\
\hline & Range & $<0.01-0.04$ & $<0.01-0.037$ & $<0.001-0.001$ & $<0.001-0.004$ & $<0.008-0.03$ & $<0.008-0.03$ \\
\hline \multirow[t]{3}{*}{ Tapps Island } & Median & 0.007 & 0.018 & $<0.001$ & $<0.001$ & $<0.008$ & $<0.008$ \\
\hline & Mean & 0.014 & 0.03 & 0.001 & 0.001 & $<0.008$ & $<0.008$ \\
\hline & Range & $<0.01-0.019$ & $<0.01-0.1$ & $<0.001-0.001$ & $<0.001-0.002$ & $<0.008-0.029$ & $<0.008-0.031$ \\
\hline \multirow[t]{3}{*}{ Snag Island } & Median & 0.011 & 0.22 & $<0.001$ & 0.001 & $<0.008$ & $<0.008$ \\
\hline & Mean & 0.017 & 0.297 & 0.001 & 0.001 & $<0.008$ & $<0.008$ \\
\hline & Range & $<0.01-0.026$ & $0.02-0.85$ & $<0.001-0.001$ & $<0.001-0.003$ & $<0.008-0.03$ & $<0.008-0.031$ \\
\hline \multirow[t]{3}{*}{ Lake Inlet } & Median & 0.009 & 0.008 & 0.001 & $<0.001$ & $<0.008$ & $<0.008$ \\
\hline & Mean & 0.009 & 0.01 & 0.001 & $<0.001$ & $<0.008$ & $<0.008$ \\
\hline & Range & $<0.01-0.012$ & $<.001-0.014$ & $<0.001-0.001$ & $<0.001-0.001$ & $<0.008-0.019$ & $<0.008-0.02$ \\
\hline \multirow[t]{3}{*}{ Southeast Arm } & Median & $<0.01$ & ND & $<0.001$ & $<0.001$ & $<0.008$ & $<0.008$ \\
\hline & Mean & 0.01 & - & 0.001 & $<0.001$ & $<0.008$ & $<0.008$ \\
\hline & Range & $<0.01-0.014$ & - & $<0.001-0.001$ & $<0.001-0.001$ & $<0.008$ & $<0.008-0.01$ \\
\hline \multirow[t]{3}{*}{ Lake Outlet } & Median & 0.008 & 0.01 & $<0.001$ & $<0.001$ & $<0.008$ & $<0.008$ \\
\hline & Mean & 0.013 & 0.013 & 0.001 & 0.001 & $<0.008$ & $<0.008$ \\
\hline & Range & $<0.01-0.0038$ & $<0.01-0.035$ & $<0.001-0.003$ & $<0.001-0.001$ & $<0.008-0.029$ & $<0.008-0.03$ \\
\hline \multirow[t]{3}{*}{ Dike 2B } & Median & 0.005 & $<0.01$ & $<0.001$ & $<0.001$ & $<0.008$ & $<0.008$ \\
\hline & Mean & 0.025 & 0.014 & 0.001 & 0.001 & $<0.008$ & $<0.008$ \\
\hline & Range & $<0.01-0.046$ & $<0.01-0.035$ & $<0.001-0.002$ & $<.001-0.002$ & $<0.008-0.031$ & $<0.008-0.03$ \\
\hline
\end{tabular}


Table 11. Summary statistics of water-quality properties and concentrations of nutrients, total suspended solids, fecal-coliform bacteria, and chlorophyll a for nine Lake Tapps study sites, Washington, July-December 2010._Continued

[Statistics calculated with censoring levels set to a common level for each constituent, which entailed using water year 2011 method detection limits to match 2010 laboratory reporting levels and are not rounded to standard USGS significant figures. Abbreviations: CFU/100 mL, colony forming units per 100 milliliters; mg/L, milligram per liter; $\mu \mathrm{S} / \mathrm{cm}$, microsiemens per centimeter at $25^{\circ} \mathrm{C}$; ${ }^{\circ} \mathrm{C}$, degrees Celsius; e, estimated; m, meters; $\mu \mathrm{g} / \mathrm{L}$, microgram per liter; NTRU, nephelometric turbidity ratio units; ND, no detections above method detection level; <, less than; -, no data or not applicable]

\begin{tabular}{|c|c|c|c|c|c|c|c|}
\hline \multirow[b]{2}{*}{ Site } & \multirow[b]{2}{*}{ Statistic } & \multicolumn{2}{|c|}{$\begin{array}{l}\text { Total } \\
\text { nitrogen, } \\
\text { filtered } \\
(\mathrm{mg} / \mathrm{L})\end{array}$} & \multicolumn{2}{|c|}{$\begin{array}{c}\text { Total } \\
\text { nitrogen, } \\
\text { unfiltered } \\
(\mathrm{mg} / \mathrm{L})\end{array}$} & \multicolumn{2}{|c|}{$\begin{array}{l}\text { Orthophosphate } \\
\text { phosphorus, } \\
\text { filtered } \\
\text { (mg/L) }\end{array}$} \\
\hline & & Epilimnion & Hypolimnion & Epilimnion & Hypolimnion & Epilimnion & Hypolimnion \\
\hline \multirow[t]{3}{*}{ Deep } & Median & 0.116 & 0.255 & 0.14 & 0.301 & $<0.004$ & 0.007 \\
\hline & Mean & 0.119 & 0.271 & 0.142 & 0.298 & 0.004 & 0.008 \\
\hline & Range & $0.07-0.19$ & $0.08-0.72$ & $0.1-0.18$ & $0.08-0.77$ & $<0.004-0.005$ & $<0.004-0.054$ \\
\hline \multirow[t]{3}{*}{ Allan Yorke } & Median & 0.125 & 0.129 & 0.176 & 0.167 & $<0.004$ & $<0.004$ \\
\hline & Mean & 0.129 & 0.139 & 0.178 & 0.185 & $<0.004$ & $<0.004$ \\
\hline & Range & $0.08-0.18$ & $0.1-0.2$ & $0.13-0.26$ & $0.13-0.25$ & $<.0004-0.006$ & $<0.004-0.006$ \\
\hline \multirow[t]{3}{*}{ Northeast Arm } & Median & 0.122 & 0.134 & 0.152 & 0.154 & $<0.004$ & $<0.004$ \\
\hline & Mean & 0.119 & 0.133 & 0.140 & 0.157 & $<0.004$ & $<0.004$ \\
\hline & Range & $0.07-0.12$ & $0.1-0.15$ & $0.11-0.2$ & $0.12-0.2$ & $<0.004-0.005$ & $<0.004-0.004$ \\
\hline \multirow[t]{3}{*}{ Tapps Island } & Median & 0.120 & 0.134 & 0.138 & 0.165 & $<0.004$ & $<0.004$ \\
\hline & Mean & 0.118 & 0.138 & 0.133 & 0.192 & 0.004 & $<0.004$ \\
\hline & Range & $0.09-0.16$ & $0.1-0.2$ & $0.11-0.16$ & $0.15-0.36$ & $<0.004-0.004$ & $<0.004-0.005$ \\
\hline \multirow[t]{3}{*}{ Snag Island } & Median & 0.12 & 0.366 & 0.156 & 0.372 & $<0.004$ & 0.006 \\
\hline & Mean & 0.132 & 0.479 & 0.148 & 0.508 & $<0.004$ & 0.005 \\
\hline & Range & $0.07-0.25$ & $0.14-1.1$ & $0.1-0.17$ & $0.16-1.4$ & $<0.004-0.005$ & $<0.004-0.007$ \\
\hline \multirow[t]{3}{*}{ Lake Inlet } & Median & 0.116 & 0.11 & 0.175 & 0.17 & $<0.004$ & $<0.004$ \\
\hline & Mean & 0.122 & 0.141 & 0.167 & 0.178 & $<0.004$ & $<0.004$ \\
\hline & Range & $0.09-0.17$ & $0.09-0.26$ & $0.12-0.21$ & $0.12-0.35$ & $<0.004$ & $<0.004-0.004$ \\
\hline \multirow[t]{3}{*}{ Southeast Arm } & Median & 0.124 & 0.13 & 0.166 & 0.181 & $<0.004$ & $<0.004$ \\
\hline & Mean & 0.13 & 0.132 & 0.168 & 0.186 & $<0.004$ & $<0.004$ \\
\hline & Range & $0.08-0.2$ & $0.1-0.21$ & $0.14-0.2$ & $0.14-0.25$ & $<0.004-0.005$ & $<0.004$ \\
\hline \multirow[t]{3}{*}{ Lake Outlet } & Median & 0.118 & 0.118 & 0.150 & 0.142 & $<0.004$ & 0.004 \\
\hline & Mean & 0.114 & 0.118 & 0.157 & 0.151 & 0.004 & 0.004 \\
\hline & Range & $0.07-0.14$ & $0.08-0.15$ & $0.11-0.27$ & $0.1-0.2$ & $<0.004-0.005$ & $<0.004-0.005$ \\
\hline \multirow[t]{3}{*}{ Dike 2B } & Median & 0.103 & 0.115 & 0.136 & 0.138 & $<0.004$ & $<0.004$ \\
\hline & Mean & 0.102 & 0.112 & 0.132 & 0.191 & 0.004 & 0.004 \\
\hline & Range & $0.07-0.13$ & $0.09-0.13$ & $0.1-0.18$ & $0.11-0.66$ & $<0.004-0.005$ & $<0.004-0.005$ \\
\hline
\end{tabular}


Table 11. Summary statistics of water-quality properties and concentrations of nutrients, total suspended solids, fecal-coliform bacteria, and chlorophyll a for nine Lake Tapps study sites, Washington, July-December 2010. - Continued

[Statistics calculated with censoring levels set to a common level for each constituent, which entailed using water year 2011 method detection limits to match 2010 laboratory reporting levels and are not rounded to standard USGS significant figures. Abbreviations: CFU/100 mL, colony forming units per 100 milliliters; mg/L, milligram per liter; $\mu \mathrm{S} / \mathrm{cm}$, microsiemens per centimeter at $25^{\circ} \mathrm{C}$; ${ }^{\circ} \mathrm{C}$, degrees Celsius; e, estimated; m, meters; $\mu \mathrm{g} / \mathrm{L}$, microgram per liter; NTRU, nephelometric turbidity ratio units; ND, no detections above method detection level; <, less than; -, no data or not applicable]

\begin{tabular}{|c|c|c|c|c|c|c|c|}
\hline \multirow[b]{2}{*}{ Site } & \multirow[b]{2}{*}{ Statistic } & \multicolumn{2}{|c|}{$\begin{array}{l}\text { Phosphorus, } \\
\text { filtered } \\
\text { (mg/L) }\end{array}$} & \multicolumn{2}{|c|}{$\begin{array}{l}\text { Phosphorus, } \\
\text { unfiltered } \\
\text { (mg/L) }\end{array}$} & \multirow{2}{*}{$\begin{array}{c}\begin{array}{c}\text { Chlorophyll } a, \\
(\mu \mathrm{g} / \mathrm{L})\end{array} \\
\text { Epilimnion }\end{array}$} & \multirow{2}{*}{$\begin{array}{c}\begin{array}{c}\text { Pheophytin } a, \\
(\mu \mathrm{g} / \mathrm{L})\end{array} \\
\text { Epilimnion }\end{array}$} \\
\hline & & Epilimnion & Hypolimnion & Epilimnion & Hypolimnion & & \\
\hline \multirow[t]{3}{*}{ Deep } & Median & $<0.003$ & 0.003 & 0.004 & 0.01 & 0.74 & 0.34 \\
\hline & Mean & $<0.003$ & 0.005 & 0.005 & 0.017 & 0.81 & 0.35 \\
\hline & Range & $<0.003-0.004$ & $<0.003-0.056$ & $<0.004-0.007$ & $<0.004-0.074$ & $0.4-1.4$ & $0.1-0.5$ \\
\hline \multirow[t]{3}{*}{ Allan Yorke } & Median & $<0.003$ & $<0.003$ & 0.009 & 0.011 & 2.06 & 1.03 \\
\hline & Mean & $<0.003$ & 0.003 & 0.009 & 0.011 & 2.92 & 1.12 \\
\hline & Range & $<0.003-0.004$ & $<0.003-0.005$ & $0.007-0.012$ & $0.008-0.015$ & $1.4-10$ & $0.5-2.1$ \\
\hline \multirow[t]{3}{*}{ Northeast Arm } & Median & $<0.003$ & $<0.003$ & 0.004 & 0.006 & 0.80 & 0.34 \\
\hline & Mean & $<0.003$ & $<0.003$ & 0.005 & 0.007 & 0.76 & 0.35 \\
\hline & Range & $<0.003-0.005$ & $<0.003-0.004$ & $<0.004-0.008$ & $<0.004-0.017$ & $0.4-1.0$ & $0.1-0.6$ \\
\hline \multirow[t]{3}{*}{ Tapps Island } & Median & $<0.003$ & 0.003 & 0.005 & 0.009 & 0.81 & 0.41 \\
\hline & Mean & $<0.003$ & 0.003 & 0.005 & 0.011 & 0.79 & 0.40 \\
\hline & Range & $<0.003$ & $<0.003-0.004$ & $<0.004-0.006$ & $0.004-0.033$ & $0.6-1.1$ & $0.2-0.5$ \\
\hline \multirow[t]{3}{*}{ Snag Island } & Median & 0.003 & 0.004 & 0.006 & 0.013 & 0.93 & 0.48 \\
\hline & Mean & $<0.003$ & 0.004 & 0.006 & 0.014 & 0.92 & 0.44 \\
\hline & Range & $<0.003-0.003$ & $<0.003-0.008$ & $<0.004-0.008$ & $0.005-0.021$ & $0.5-1.2$ & $0.2-0.7$ \\
\hline \multirow[t]{3}{*}{ Lake Inlet } & Median & $<0.003$ & $<0.003$ & 0.009 & 0.009 & 1.83 & 0.89 \\
\hline & Mean & $<0.003$ & $<0.003$ & 0.009 & 0.01 & 2.05 & 0.83 \\
\hline & Range & $<0.003-0.005$ & $<0.003-0.004$ & $0.007-0.012$ & $0.006-0.012$ & $0.7-3.9$ & $0.3-1.2$ \\
\hline \multirow[t]{3}{*}{ Southeast Arm } & Median & $<0.003$ & $<0.003$ & 0.011 & 0.013 & 2.16 & 1.20 \\
\hline & Mean & 0.003 & $<0.003$ & 0.011 & 0.013 & 2.82 & 1.12 \\
\hline & Range & $<0.003-0.004$ & $<0.003-0.004$ & $0.008-0.013$ & $0.01-0.021$ & $1.1-5.8$ & $0.4-1.6$ \\
\hline \multirow[t]{3}{*}{ Lake Outlet } & Median & $<0.003$ & $<0.003$ & 0.005 & 0.006 & 0.80 & 0.38 \\
\hline & Mean & $<0.003$ & $<0.003$ & 0.005 & 0.009 & 0.81 & 0.39 \\
\hline & Range & $<0.003-0.005$ & $<0.003-0.006$ & $<0.004-0.008$ & $0.004-0.034$ & $0.6-1.1$ & $0.3-0.5$ \\
\hline \multirow[t]{3}{*}{ Dike 2B } & Median & $<0.003$ & $<0.003$ & 0.005 & 0.005 & 0.64 & 0.33 \\
\hline & Mean & $<0.003$ & $<0.003$ & 0.005 & 0.013 & 0.69 & 0.35 \\
\hline & Range & $<0.003-0.003$ & $<0.003$ & $<0.004-0.007$ & $<0.004-0.086$ & $0.5-1.0$ & $0.3-0.5$ \\
\hline
\end{tabular}




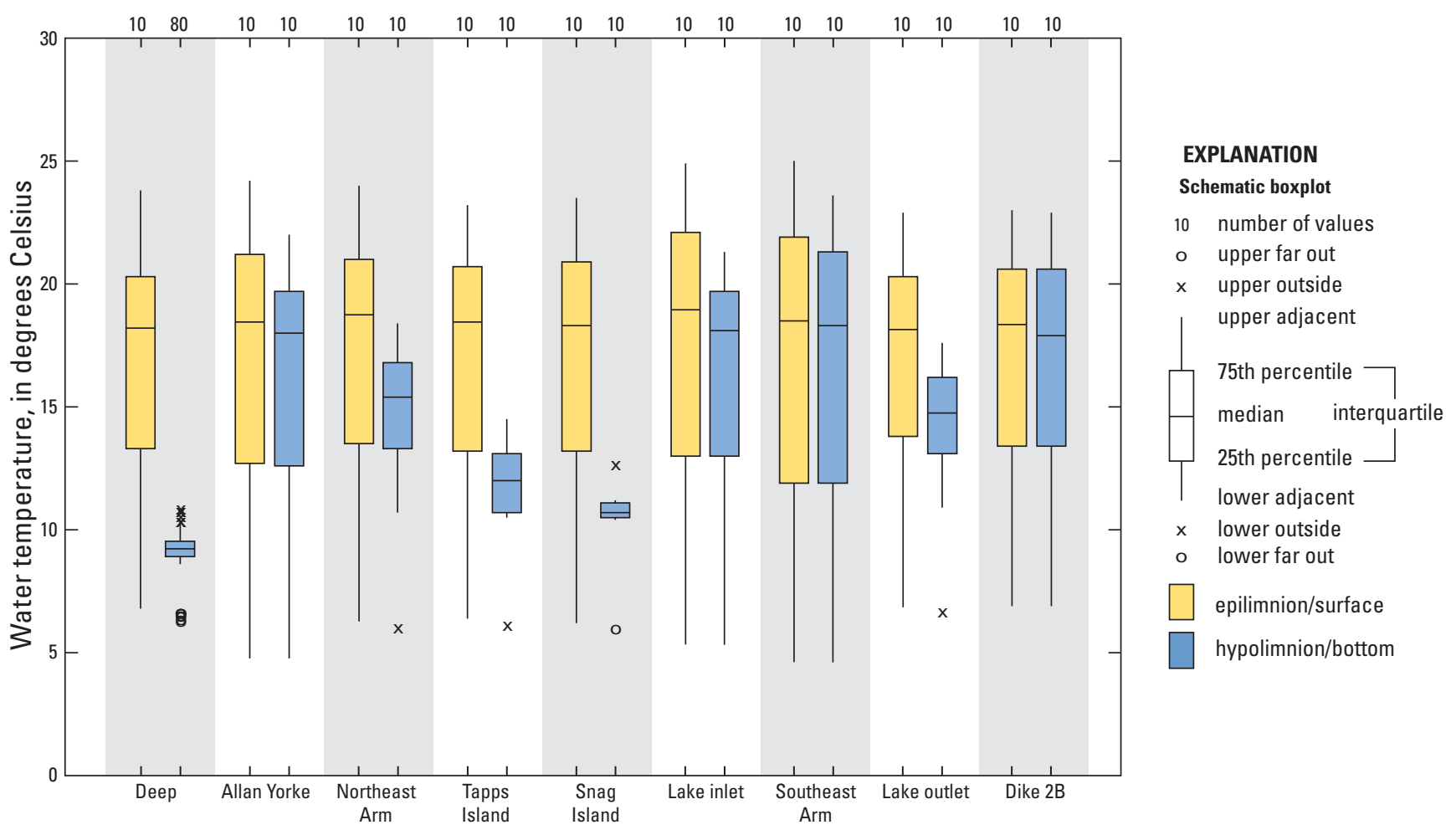

Figure 14. Water temperature measured in the epilimnion (or near the surface) and hypolimnion (or near the bottom) at Lake Tapps study sites, Washington, July-December 2010. Adjacent values are last observation less than 1.5 times the interquartile range beyond the end of the box. Outside values are observations 1.5-3 times the interquartile range. Far out values are observations greater than 3 times the interquartile range.

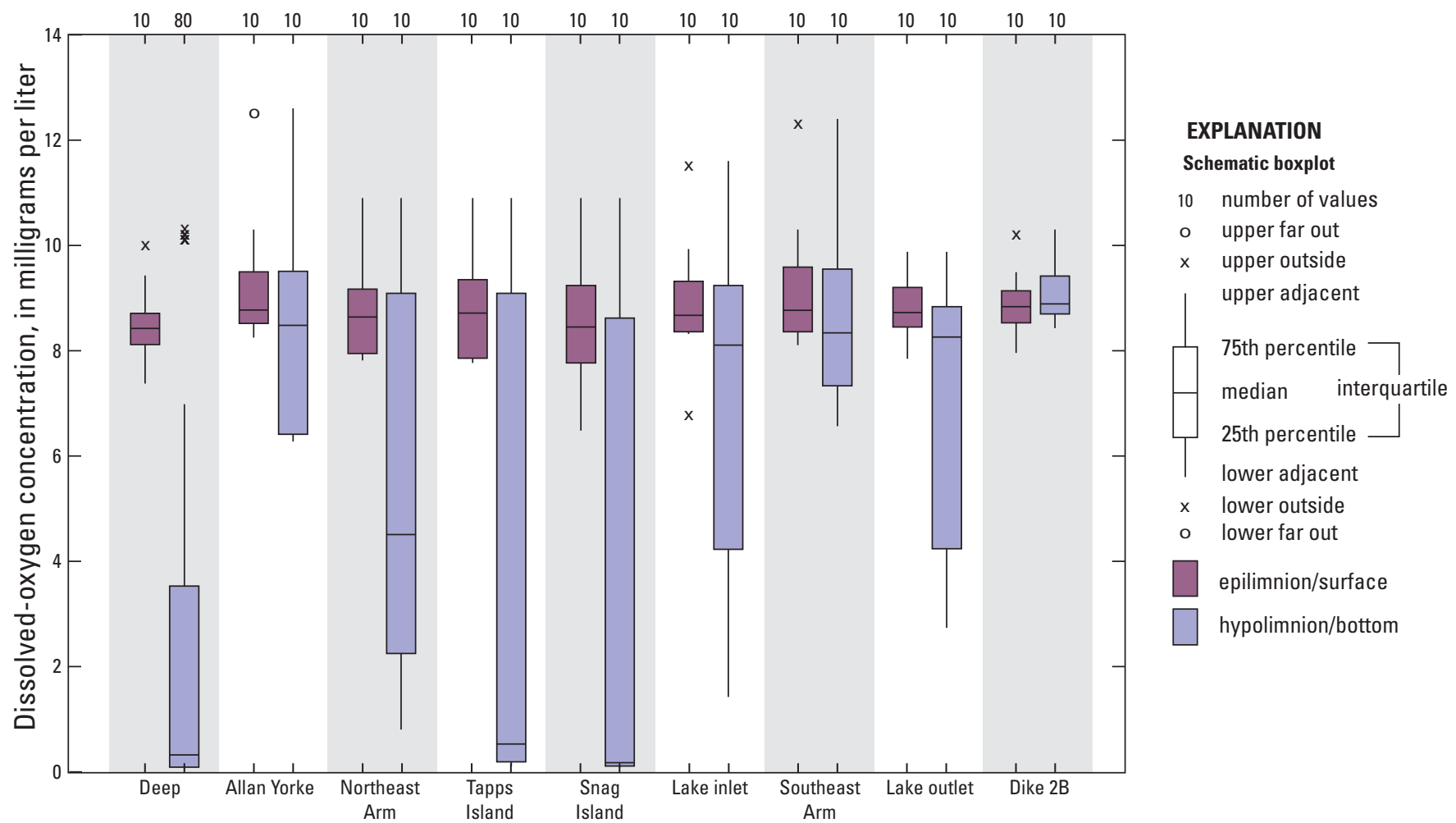

Figure 15. Dissolved oxygen concentrations measured in the epilimnion (or near surface) and hypolimnion (or near bottom) at Lake Tapps study sites, Washington, July-December 2010. Adjacent values are last observations less than 1.5 times the interquartile range beyond the end of the box. Outside values are observations 1.5-3 times the interquartile range. Far out values are observations greater than 3 time the interquartile range. 


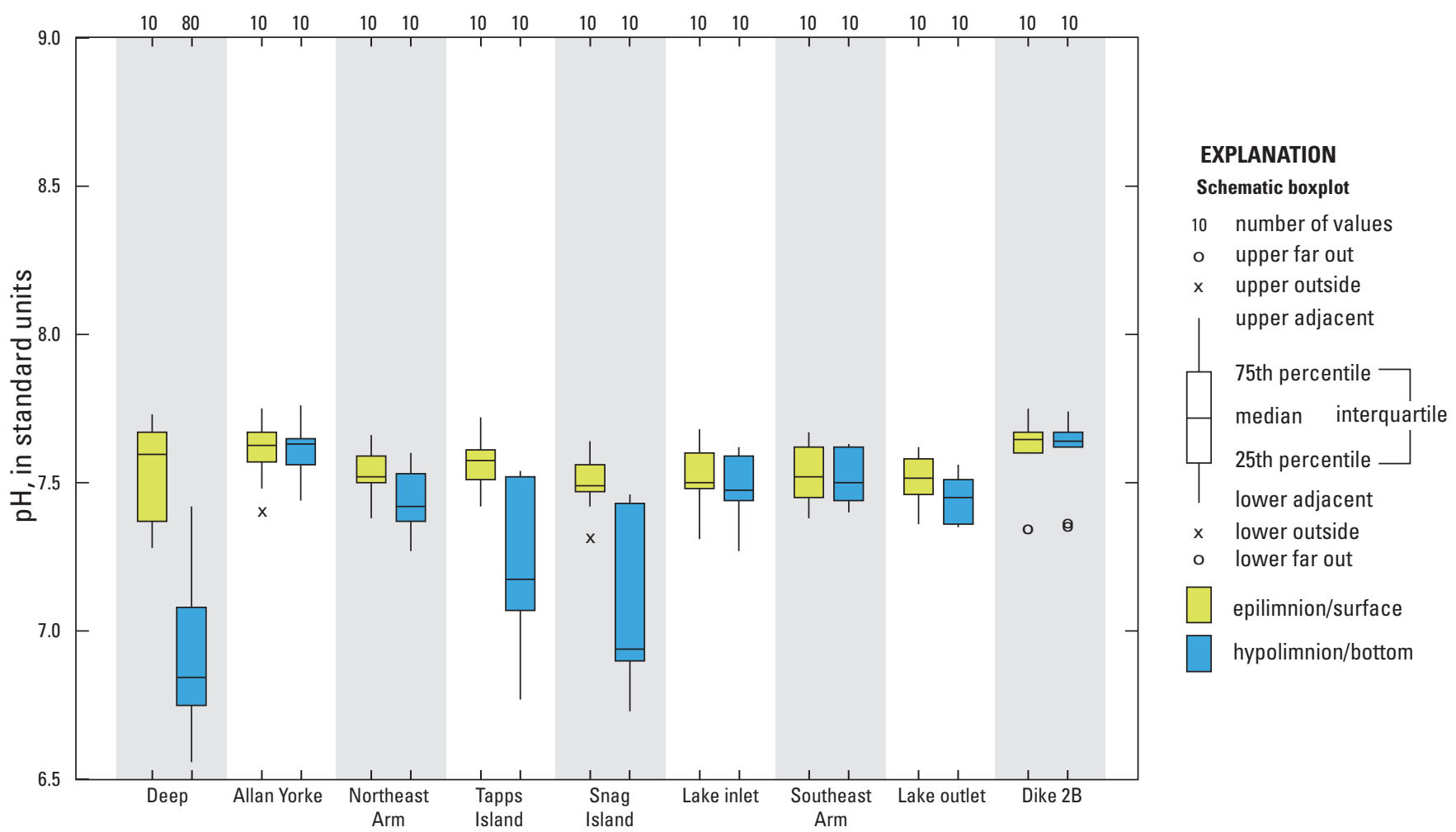

Figure 16. pH measured in the epilimnion (or near the surface) and hypolimnion (or near the bottom) at Lake Tapps study sites, Washington, July-December 2010. Adjacent values are last observation less than 1.5 times the interquartile range beyond the end of the box. Outside values are observations 1.5-3 times the interquartile range. Far out values are observations greater than 3 times the interquartile range.

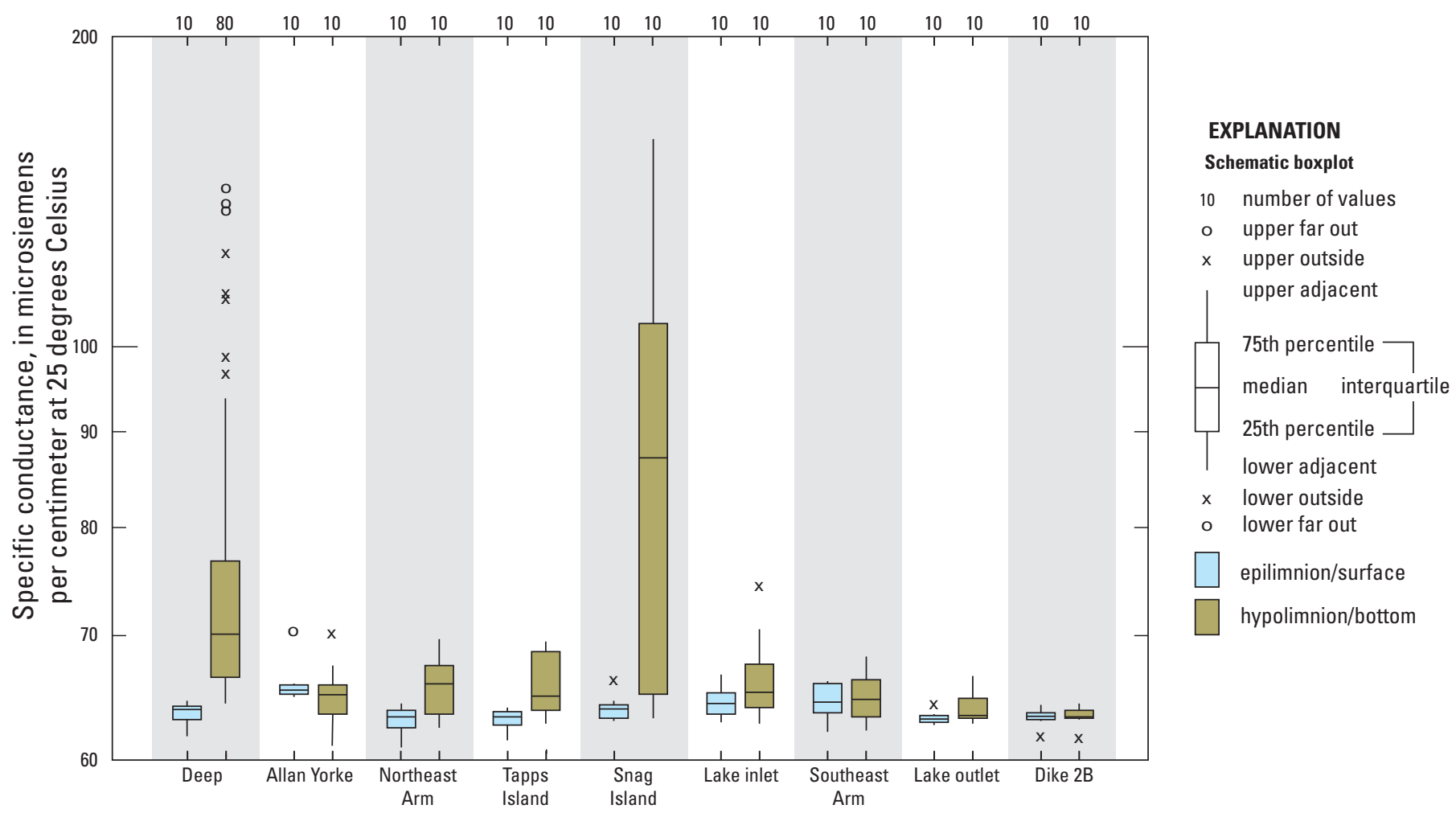

Figure 17. Specific conductance measured in the epilimnion (or near the surface) and hypolimnion (or near the bottom) at Lake Tapps study sites, Washington, July-December 2010. Adjacent values are last observation less than 1.5 times the interquartile range beyond the end of the box. Outside values are observations 1.5-3 times the interquartile range. Far out values are observations greater than 3 times the interquartile range. 


\section{Total Suspended Solids and Fecal-Coliform Bacteria}

Concentrations of TSS throughout the lake were low with values typically less than $10 \mathrm{mg} / \mathrm{L}$ and several with concentrations less than the laboratory reporting level of $1.1 \mathrm{mg} / \mathrm{L}$. At six of the nine study sites (Deep, Northeast Arm,
Tapps Island, Snag Island, Lake Outlet, and Dike 2B), median concentrations in samples from the epilimnion were less than $1.1 \mathrm{mg} / \mathrm{L}$ (table 11). The highest median concentrations were observed at the Southeast Arm site with a median of $3.6 \mathrm{mg} / \mathrm{L}$ for the epilimnion and $3.8 \mathrm{mg} / \mathrm{L}$ for the hypolimnion. At the Deep site, TSS concentrations in the hypolimnion were as high as $30 \mathrm{mg} / \mathrm{L}$ depending on sample depth (fig. 18).

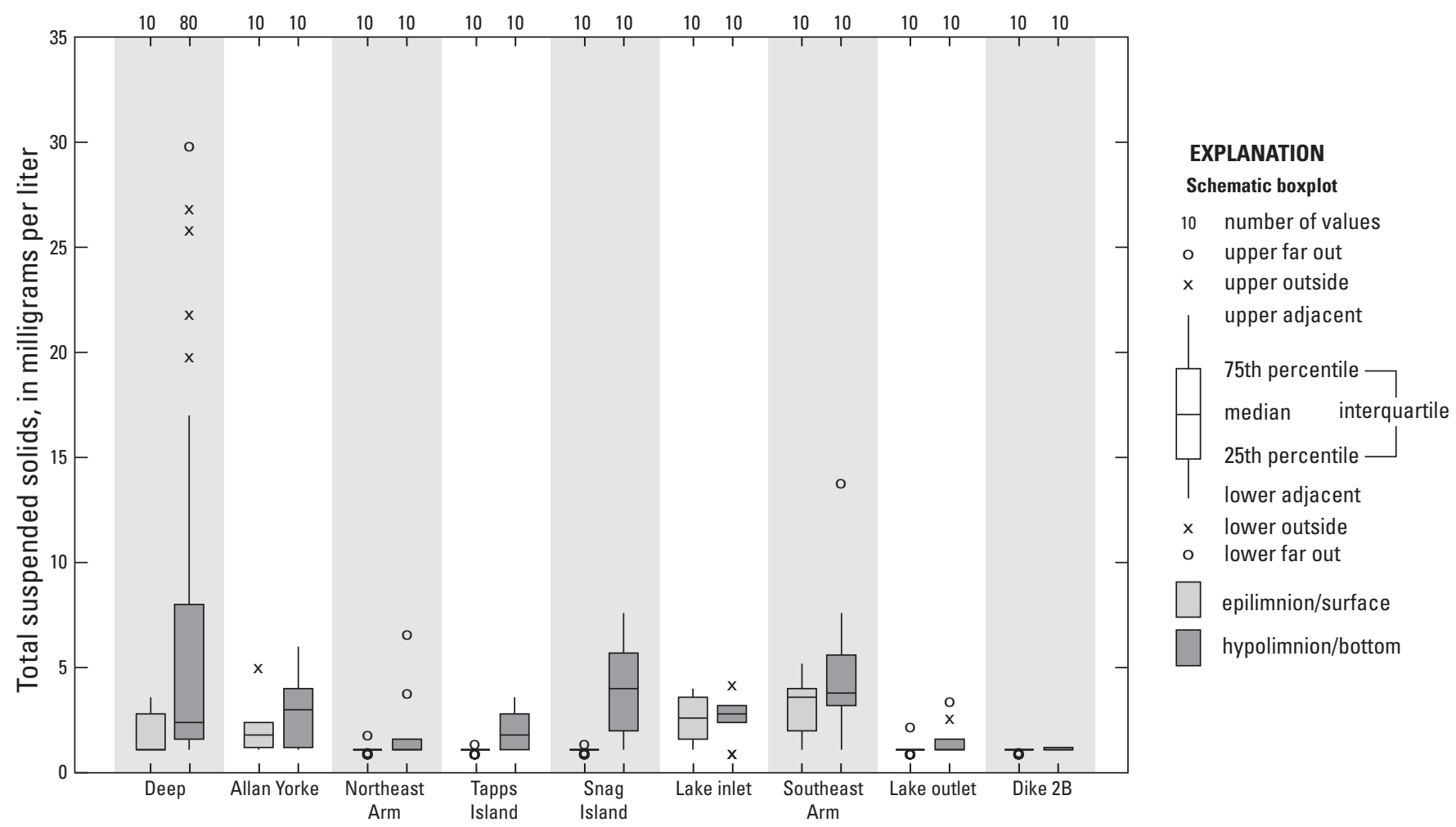

Figure 18. Total suspended solids measured in the epilimnion (or near the surface) and hypolimnion (or near the bottom) at Lake Tapps study sites, Washington, July-December 2010. Adjacent values are last observation less than 1.5 times the interquartile range beyond the end of the box. Outside values are observations $1.5-3$ times the interquartile range. Far out values are observations greater than 3 times the interquartile range. 
The microbial quality of the lake water at the nine sampling sites is considered excellent for the purposes of this study in that 24 percent of samples had concentrations of less than $1 \mathrm{CFU} / 100 \mathrm{~mL}$ of fecal-coliform bacteria, and of the remaining samples with detections, 60 percent had concentrations of $5 \mathrm{CFU} / 100 \mathrm{~mL}$ or less. In addition, all samples positive for fecal-coliform bacteria had concentrations that would meet the Washington State single sample freshwater criterion for extraordinary primary contact recreation of less than $100 \mathrm{CFU} / 100 \mathrm{~mL}$ (Washington State Department of Ecology, 2011).

\section{Nutrients and Chlorophyll $a$}

Concentrations of nutrients in Lake Tapps were low at all sites during the study, and certain forms of nitrogen and phosphorus were often not detected at concentrations greater than the laboratory method detection levels. Median epilimnion concentrations of total nitrogen (unfiltered water) ranged from about $0.14 \mathrm{mg} / \mathrm{L}$ at the Deep, Tapps Island, and Dike 2B sites to about $0.18 \mathrm{mg} / \mathrm{L}$ at the Allan Yorke and Lake Inlet sites; and median epiliminion concentrations of total phosphorus (unfiltered water) ranged from $0.004 \mathrm{mg} / \mathrm{L}$ at the Deep and Northeast Arm sites to 0.011 at the Southeast Arm site (table 11). Higher concentrations of total nitrogen and total phosphorus were observed for hypolimnion samples than for epilimnion samples. Median hypolimnion concentrations of total nitrogen ranged from about $0.14 \mathrm{mg} / \mathrm{L}$ at the Lake Outlet and Dike 2B sites to $0.372 \mathrm{mg} / \mathrm{L}$ at Snag Island; and median hypolimnion concentrations of total phosphorus ranged from $0.005 \mathrm{mg} / \mathrm{L}$ at Dike 2B to $0.013 \mathrm{mg} / \mathrm{L}$ at Snag Island and Southeast Arm.

At most sites and in most samples from the epilimnion, total phosphorus concentrations were less the Washington State phosphorus criterion of $0.01 \mathrm{mg} / \mathrm{L}$ for maintaining oligotrophic conditions (Moore and Hicks, 2004) (fig. 19). A few samples from the epilimnion at the Allan Yorke and Lake Inlet sites had concentrations greater than $0.01 \mathrm{mg} / \mathrm{L}$, yet they were still well below the Washington State action value of $0.02 \mathrm{mg} / \mathrm{L}$ for preserving mesotrophic conditions (Moore and Hicks, 2004). At the Southeast Arm site, all sample concentrations except one exceeded $0.01 \mathrm{mg} / \mathrm{L}$, but none was greater than $0.02 \mathrm{mg} / \mathrm{L}$ (fig. 19).

The State of Washington does not govern nitrogen concentrations with an absolute standard or criterion (Moore and Hicks, 2004). However, during the process of developing the phosphorus criteria, the consensus was that ratios of total nitrogen-to-total phosphorus greater than 10-to-1 should be maintained to prevent cyanobacteria (blue-green algae) dominance over the algal community (Moore and Hicks, 2004). As an example, the Washington State Department of Ecology nutrient standards committee suggested that for a total phosphorus concentration of $0.02 \mathrm{mg} / \mathrm{L}$ to be protective, total nitrogen concentrations would need to be greater than $0.2 \mathrm{mg} / \mathrm{L}$ (Moore and Hicks, 2004). Total nitrogen concentrations in samples from the epilimnion of all sites rarely exceeded $0.2 \mathrm{mg} / \mathrm{L}$. However, this is not a concern for this study because epilimnetic total phosphorus concentrations were all less than $0.02 \mathrm{mg} / \mathrm{L}$ (fig. 19).

Concentrations of nitrite-plus-nitrate and orthophosphate in samples from the epilimnion and the hypolimnion were mostly less than laboratory method detection levels of 0.008 and $0.004 \mathrm{mg} / \mathrm{L}$, respectively (table 11). Except for a few hypolimnion samples, nitrite generally was not present in water samples at concentrations greater than the method detection level of $0.001 \mathrm{mg} / \mathrm{L}$. In the hypolimnion, nitrite was detected in at least one sample at each site at a concentration at or near the detection level of $0.001 \mathrm{mg} / \mathrm{L}$ (table 11). Ammonia was present in at least one sample from the epilimnion and hypolimnion of all sites. Median concentrations of ammonia in the epilimnion ranged from less than $0.01 \mathrm{mg} / \mathrm{L}$ at the Southeast Arm site to $0.011 \mathrm{mg} / \mathrm{L}$ at the Snag Island site. The highest ammonia concentrations in hypolimnion samples also were from the Snag Island site, with a median of $0.22 \mathrm{mg} / \mathrm{L}$; the second highest ammonia concentrations were from the hypolimnion of the Deep site with a median of $0.024 \mathrm{mg} / \mathrm{L}$.

Chlorophyll $a$ concentrations were low with median concentrations of $2.16 \mu \mathrm{g} / \mathrm{L}$ or less for all nine sites and less than $1 \mu \mathrm{g} / \mathrm{L}$ at six of the sites. Dike 2B had the lowest concentration of the nine sites with a median of $0.64 \mu \mathrm{g} / \mathrm{L}$ (table 11). Chlorophyll $a$ concentrations for the lake as a whole were moderately correlated with concentrations of unfiltered total phosphorus (coefficient of 0.61) and unfiltered total nitrogen (coefficient of 0.52). However, chlorophyll $a$ concentrations did not correlate (coefficients less than 0.37) with concentrations of ammonia, nitrite-plusnitrate, orthophosphate, filtered total phosphorus, filtered total nitrogen, and TSS. Washington State has no standard or criterion for chlorophyll $a$, but for comparison, these concentrations are well below the Oregon State action level of $10 \mu \mathrm{g} / \mathrm{L}$ to identify potential nuisance phytoplankton growth in natural lakes that thermally stratify and $15 \mu \mathrm{g} / \mathrm{L}$ in lakes and reservoirs that do not stratify (Oregon State Archives, 2003). 


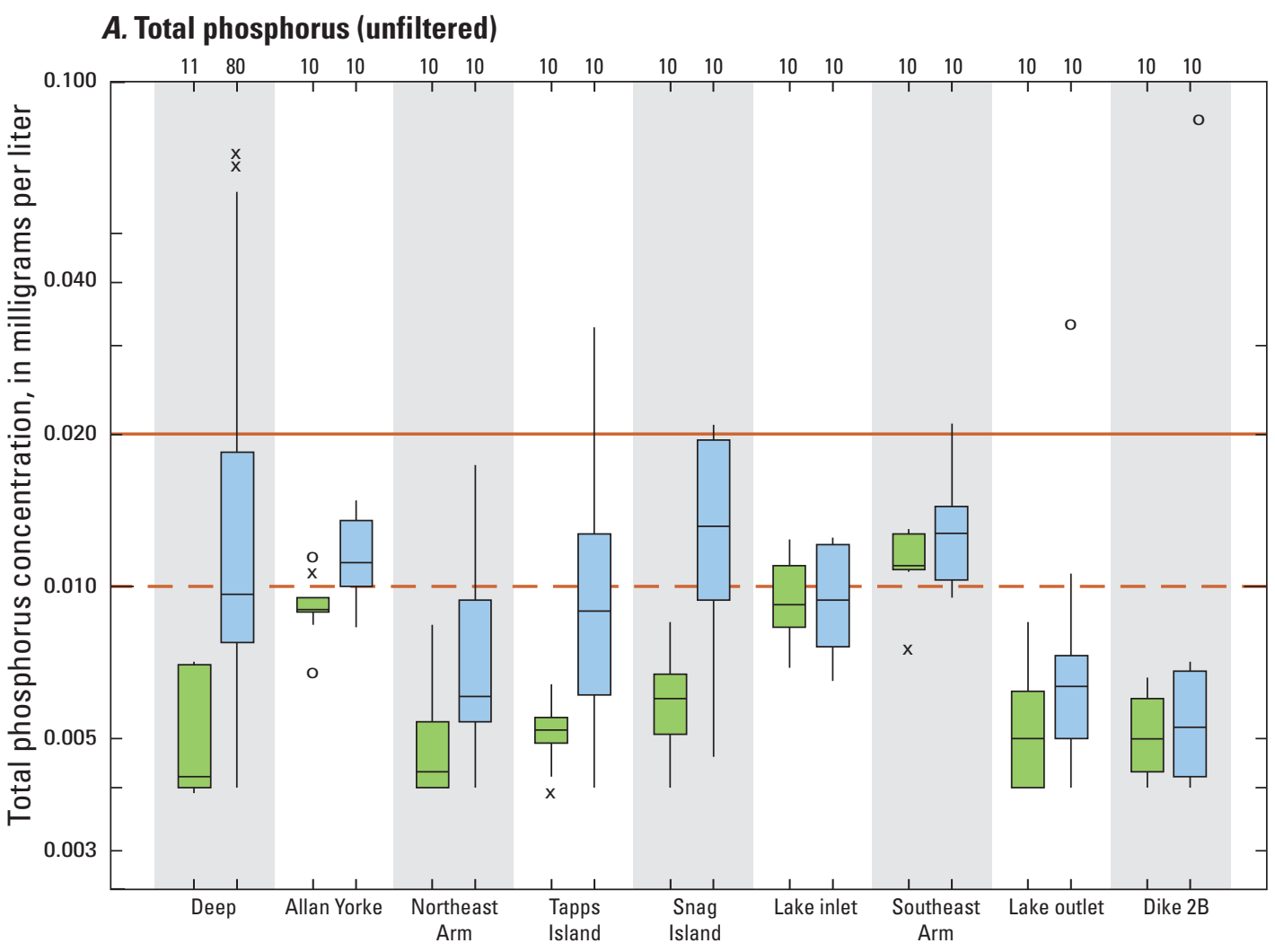

B. Total nitrogen (unfiltered)

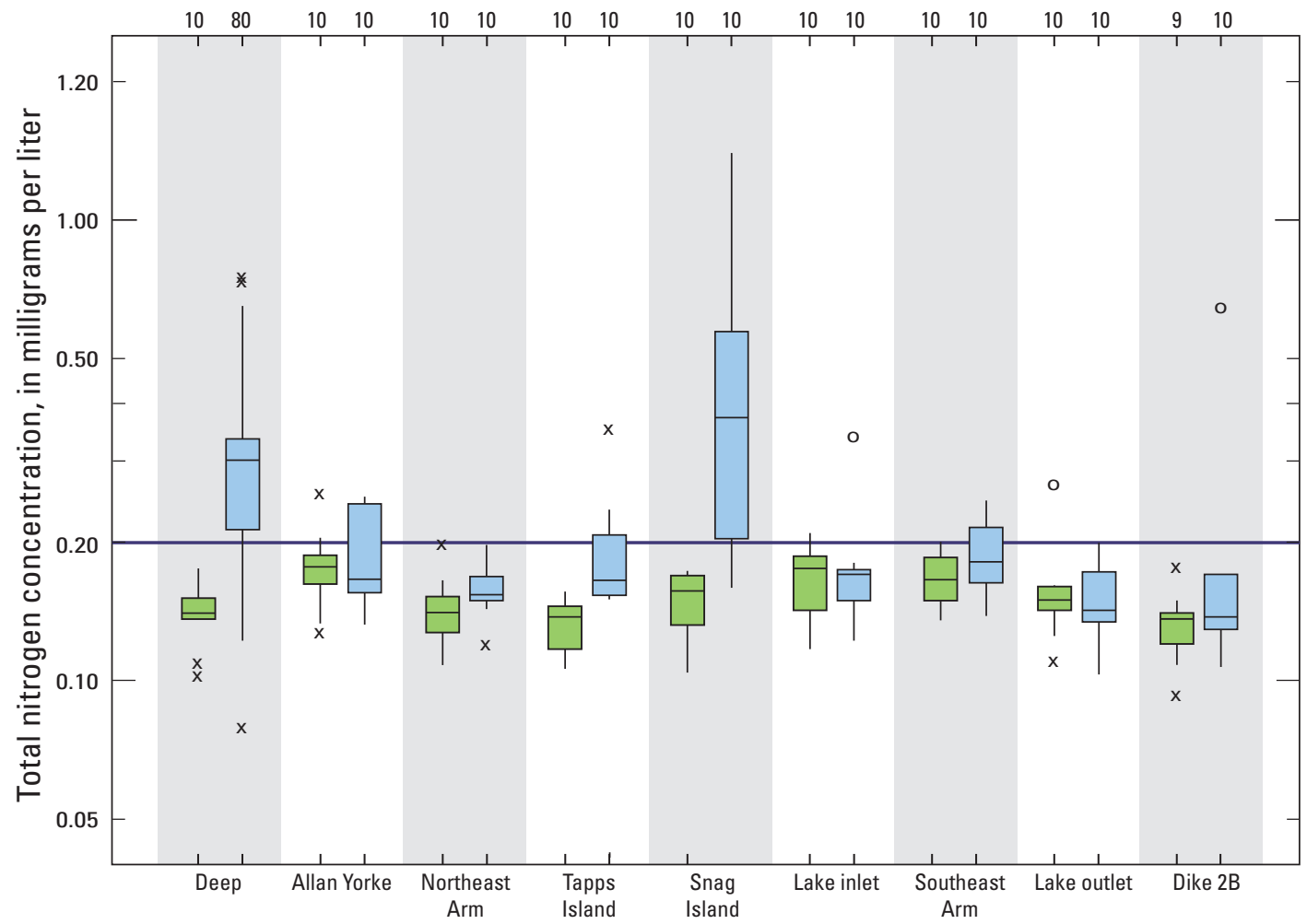

EXPLANATION

Schematic boxplot

10 number of values

o upper far out

$x$ upper outside upper adjacent

75th percentile

median interquartile

25th percentile

lower adjacent

$x \quad$ lower outside

- lower far out

epilimnion/surface

hypolimnion/bottom

Washington State phosphorus action value to maintain mesotrophic conditions

- Washington State phosphorus criterion to maintain oligotrophic conditions

— Nitrogen level for maintaining a 10 to 1 ratio with an action value of $0.02 \mathrm{mg} / \mathrm{L}$ phosphorus

Figure 19. Total phosphorus $(A)$ and total nitrogen $(B)$ measured in unfiltered water samples from the epilimnion (or near the surface) and hypolimnion (or near the bottom) at Lake Tapps study sites, Washington, July-December 2010. Adjacent values are last observation less than 1.5 times the interquartile range beyond the end of the box. Outside values are observations 1.5-3 times the interquartile range. Far out values are observations greater than 3 times the interquartile range. 


\section{Variations in Water-Quality Properties and Constituents over Time}

Multiple processes that could potentially affect the quality of water observed during the course of this study included volumes of inflow and outflow and the corresponding flow through the main body of the lake; the quality of the inflow water; and the types and intensity of land use, such as shoreline development around the lake. Importantly, data for this study were collected under unique, reduced flow conditions when dewatering of the White River Canal eliminated the primary inflow to the lake and there were no releases of water at the outflow. Other factors include physical characteristics of each site, including water depth, and location on the lake with respect to open water, narrow arms, or sheltered embayments. Weather conditions, such as rain events prior to or during sampling, also could affect measurements of physical properties and concentrations of nutrients and other constituents over time.

Analyses of the data indicate Allan Yorke, Lake Inlet, and Southeast Arm sites shared similar water-quality characteristics during the sample-collection period and these characteristics often differed from the water quality of the other study sites. For example, concentrations of water-quality constituents generally were higher in magnitude and seemed to be more sensitive to environmental conditions, such as rain events, than was observed at many of the other sites. All three sites are located in regions of shallow water, with fully developed, residential shorelines, and in proximity to the White River Canal Inflow. The area around the Southeast Arm site contains a large number of drowned, tree remnants. These three sites also are in a region of the lake that was treated during the last week of August and the week of September 13 for control of Eurasian watermilfoil (Cascade Water Alliance, 2011), which may or may not have had any influence on the observed water-quality data.

Field personnel usually described the near-surface water color at each site at the time of sampling as green. By September, water color at the Allan Yorke and Southeast Arm sites had shifted to yellowish green or brownish green and remained in this condition through December (appendix A). Personnel also described the water at these sites as somewhat turbid at these particular times.

At the Allan Yorke, Lake Inlet, and Southeast Arm sites, where total water depth is shallow (see table 2) and Secchi disk transparencies were low, there was little change in Secchi disk values from month to month over the July-December period of sample collection (fig. 20). At the other six sites, Secchi disk transparencies generally were deepest from early
July until early October, then by late October, transparencies decreased by as much as 50 percent. At Dike 2B, Secchi disk visibility, which often extended to the lake bottom during summer, decreased in late October-December. These reduced transparencies at Dike 2B were partly due to shallower water depths (from 5 to $3 \mathrm{~m}$ ) with the annual lowering of the lake water surface. The reduced transparencies (and increases in turbidity) at the sites during autumn might have been due in part to detritus from submerged vegetation die-off and to other particulate materials resuspended and circulated within the water column during rainstorms, wind turbulence, and lake turnover.

By early July, depth profiles of water temperatures showed weak, thermal stratification at most of the sites into at least a warm surface layer overlying a thermocline. The water column at the Lake Inlet, Southeast Arm and Dike 2B sites did not thermally stratify during this study (appendix F). A well-defined hypolimnion developed below the thermocline only at the Deep site. After reaching maximum surface temperatures in mid-August, stratification at the Deep site gradually weakened through mid-November, and by early December, the temperature profile showed constant temperatures from top to bottom indicating the lake had turned over at this location (fig. 21).

Although the epilimnion at all sites remained oxygenated during the study, with the development of thermal stratification during the summer, hypolimnion dissolved oxygen concentrations decreased to less than about $3 \mathrm{mg} / \mathrm{L}$ except at the Southeast Arm and Dike 2B sites (appendix F), and at the Deep, Tapps Island, Snag Island, and Lake Outlet sites, the water was anoxic at depth with concentrations less than $0.1 \mathrm{mg} / \mathrm{L}$ (appendix F). By late September at the Deep site, an anoxic layer about $15 \mathrm{~m}$ thick had formed in the hypolimnion (fig. 21). Mixing during autumn overturn in late November, however, re-oxygenated the water column of the Deep site and of all the other sites with about 10-12 mg/L of dissolved oxygen (appendix F).

Gradients in values of specific conductance and $\mathrm{pH}$ (appendix F) from surface to bottom developed during summer at all sites except at the Southeast Arm and Dike 2B sites, which also did not thermally stratify. For the most part, these gradients were weak and did not persist into September. At the Deep, Tapps Island, and Snag Island sites, stratification in specific conductance and $\mathrm{pH}$ was well-developed by the first sampling event of early July and remained in place through October. With autumn overturn and mixing, specific conductance and $\mathrm{pH}$ values in early December were essentially the same throughout the water column. 
46

Quality of Water in the White River and Lake Taps, Pierce County, Washington, May-December 2010

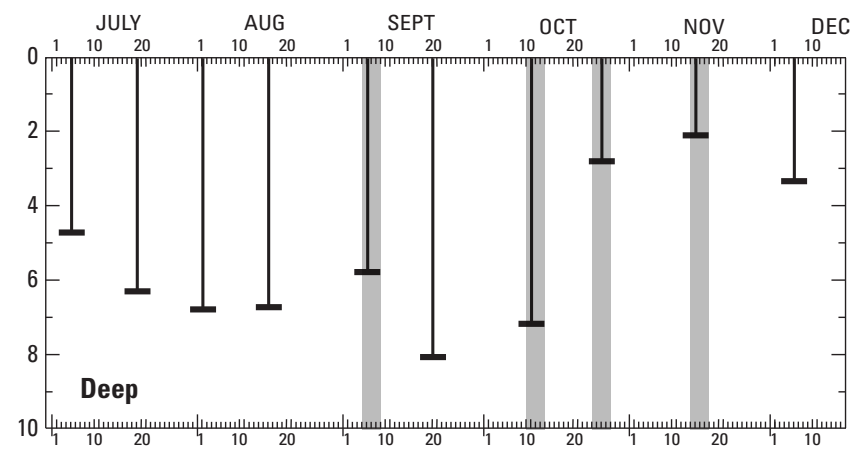

EXPLANATION

Rainfall event over 4 days2 days prior to sampling and during 2 days of sampling
Rainfall amount, in inches

1.6 - Sept 5-8

$1.3-0$ ct $10-13$

$2.3-0$ ct $24-27$

$0.9-\operatorname{Nov} 14-17$
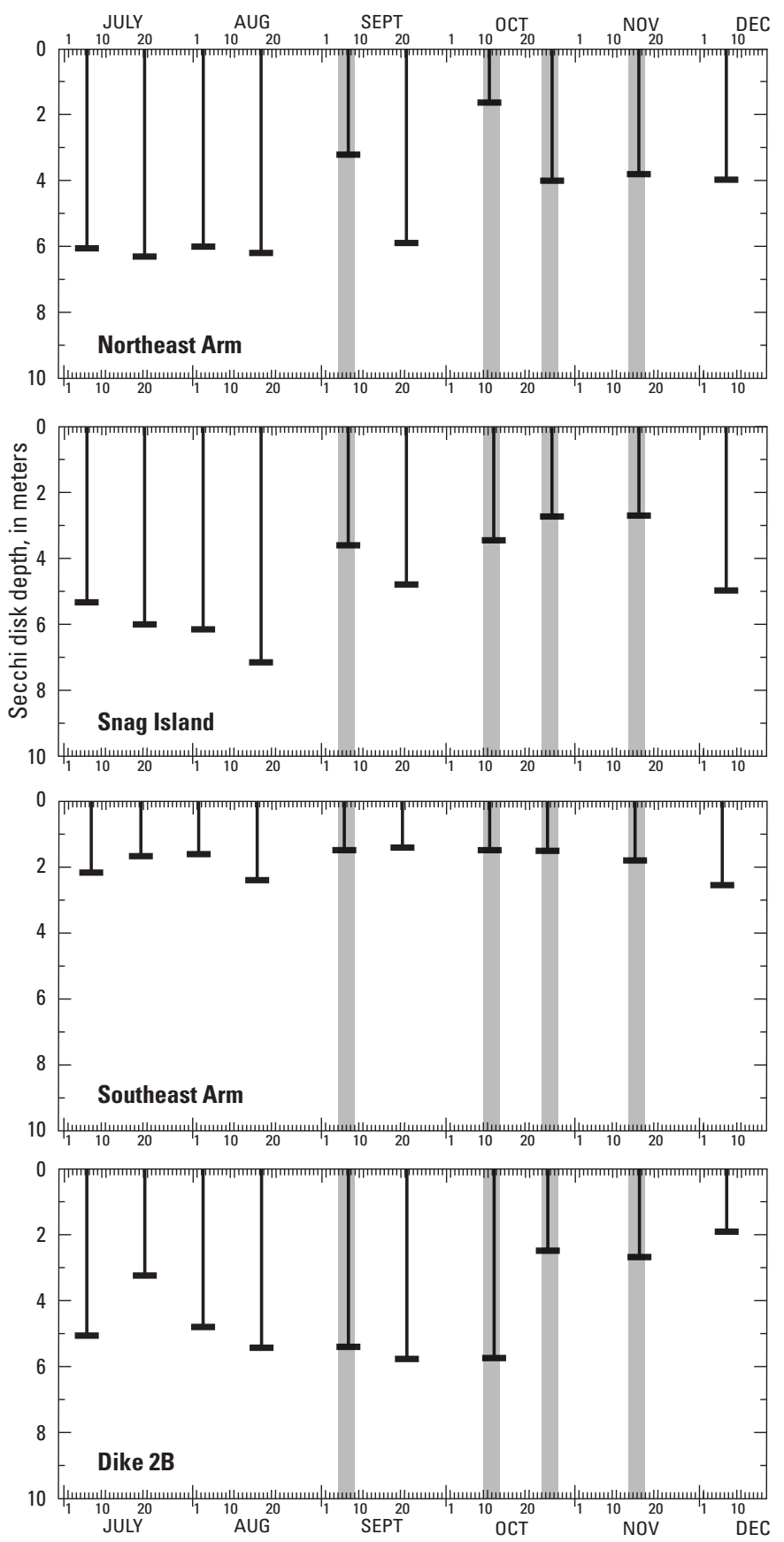

Figure 20. Sochi disk transparency depths measured at Lake Taps study sites, Washington, July-December 2010. 

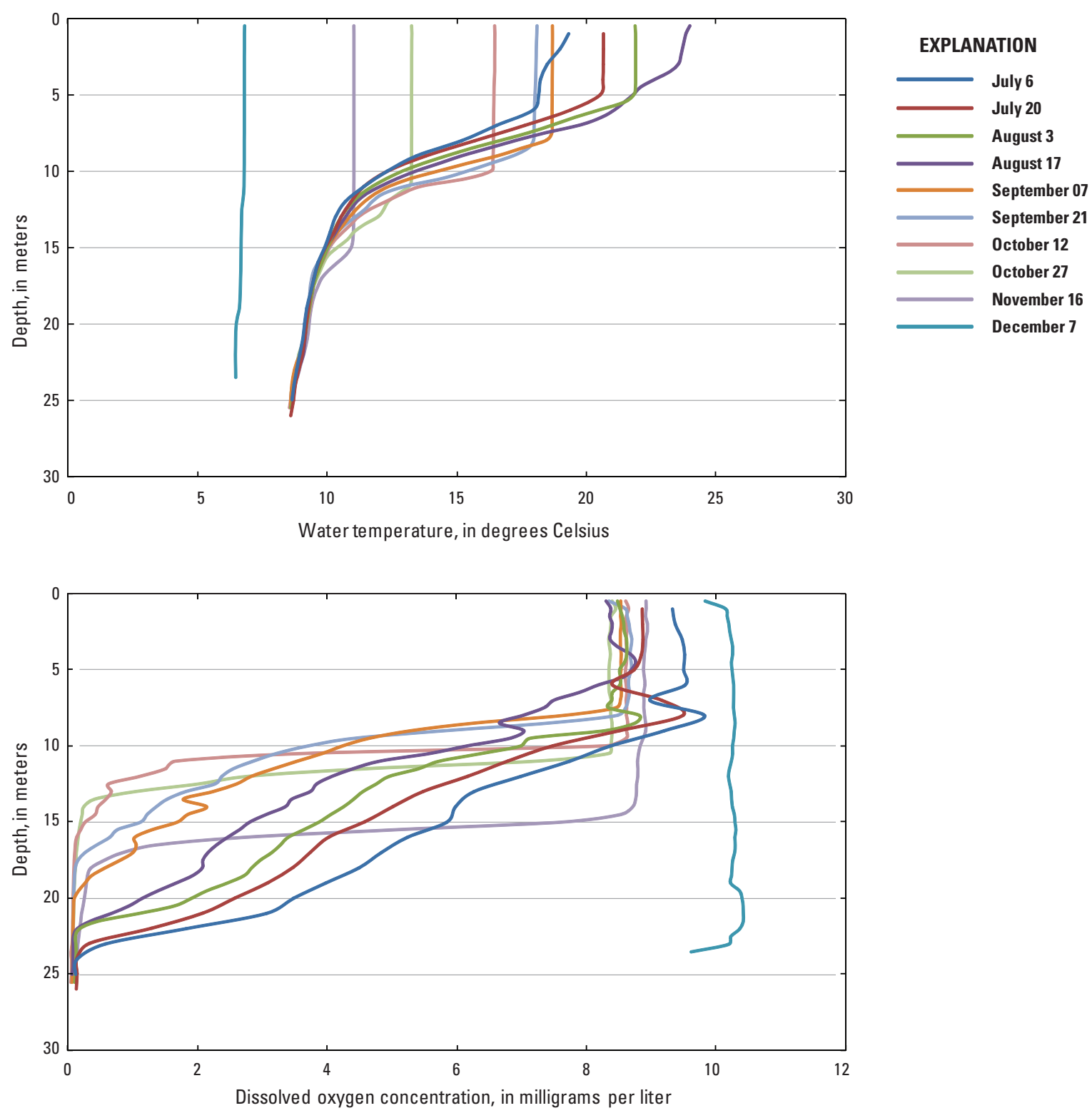

Figure 21. Water temperature and dissolved oxygen concentrations with depth at the Deep site on Lake Tapps, Washington, July-December 2010. 
During the first week of September, concentrations of TSS (ig. 22) and orthophosphate (ig. 23) in the epilimnion were elevated at several sites, particularly at Allan Yorke, Lake Inlet, and Southeast Arm. These increases might have been due to rainfall for a few days preceding and during the sampling events. The rainstorm in early September was particularly intense with a 3-day total of more than 1.6 in. of rain recorded at the McMillin Reservoir rain gage (fig. 1). During this early September sampling, concentrations of fecal-coliform bacteria at the Lake Outlet site also increased to $54 \mathrm{CFU} / 100 \mathrm{~mL}$ (fig. 24). Concentrations of nitrite-plusnitrate and chlorophyll $a$ did not respond to these two summer rain events. Summer concentrations of nitrite-plus-nitrate were nearly constant near the method detection level of $0.005 \mathrm{mg} / \mathrm{L}$ (fig. 25) and summer chlorophyll $a$ concentrations remained relatively constant at about $1 \mu \mathrm{g} / \mathrm{L}$ (fig. 26).

With the onset of autumn, epilimnion concentrations of several constituents generally increased, likely due to lake overturn and mixing of the water column by midNovember. For example, at the Deep site, fecal-coliform bacteria concentrations increased to $57 \mathrm{CFU} / 100 \mathrm{~mL}$ in November and to $68 \mathrm{CFU} / 100 \mathrm{~mL}$ in December and appear to coincide with autumn rain events and lake overturn at this location. Nitrite-plus-nitrate concentrations, which had consistently been at laboratory method detection levels, increased in November and December at all sites except at the Southeast Arm. Concentrations of chlorophyll $a$ also increased during October-December to values as high as $10 \mu \mathrm{g} / \mathrm{L}$ (at Allan Yorke).

On the basis of median values calculated using concentration data from all nine lake sites, total phosphorus and total nitrogen in the epilimnion of the lake varied little from month to month (fig. 27). Although epilimnion concentrations in October-December showed slight increases over summer concentrations, the differences between summer and autumn median values were minimal (less than $0.002 \mathrm{mg} / \mathrm{L}$ phosphorus and less than $0.03 \mathrm{mg} / \mathrm{L}$ nitrogen). Median concentrations of total phosphorus and total nitrogen in the hypolimnion (not including multi-depth samples from the Deep site) also varied little from month to month (fig. 27). As indicated by notched boxplots with overlapping confidence intervals about the median, summer and autumn concentrations of total phosphorus for the epilimnion and total nitrogen for the hypolimnion were not significantly different (significance level of about 5 percent). Autumn concentrations of total nitrogen for the epilimnion and total phosphorus for the hypolimnion, however, were significantly higher (non-overlapping confidence intervals) than summer concentrations, but the differences are small (fig. 27).

Total suspended solids concentrations

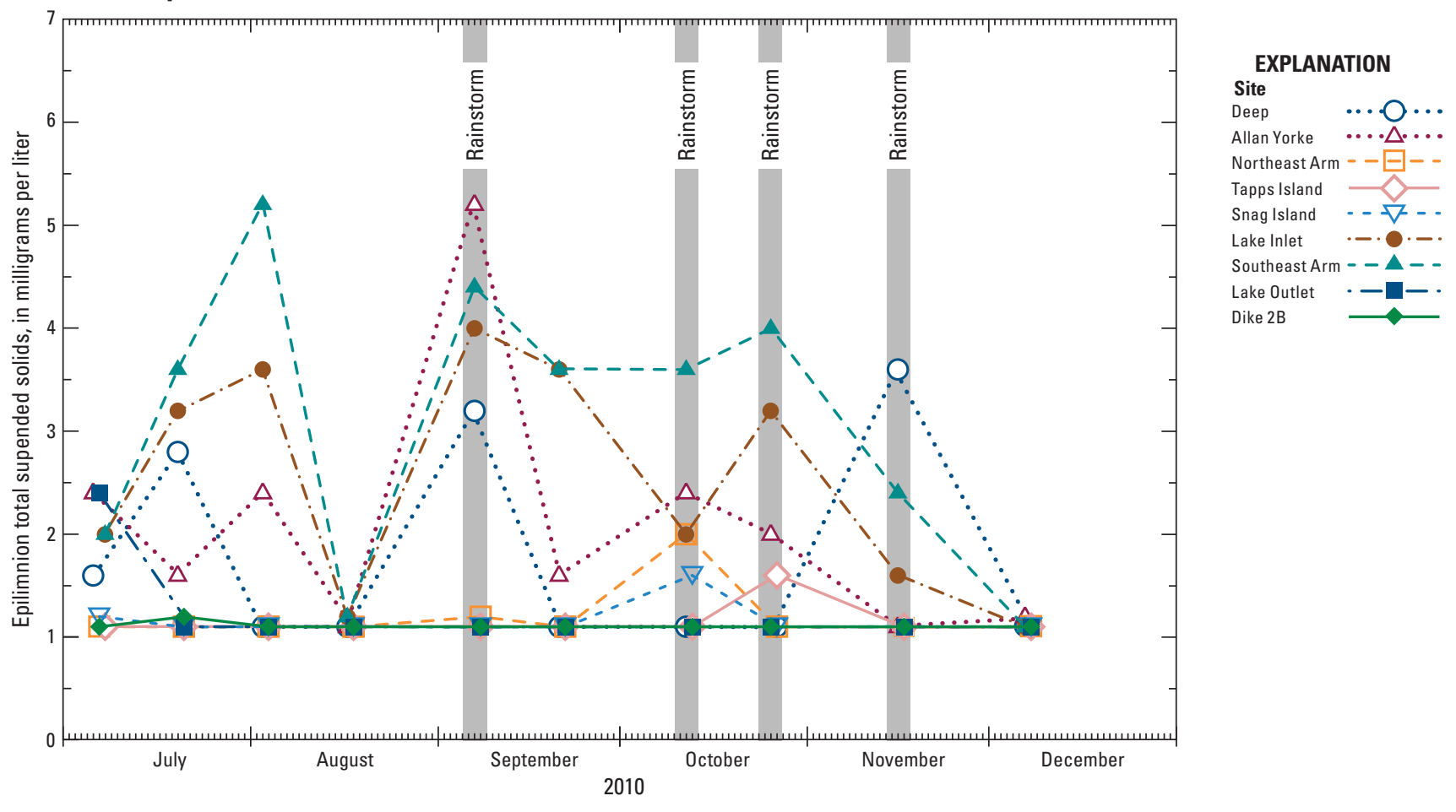

Figure 22. Total suspended solids concentrations by sample date for Lake Tapps study sites, Washington, July-December 2010. 
Orthophosphate phosphorus concentrations

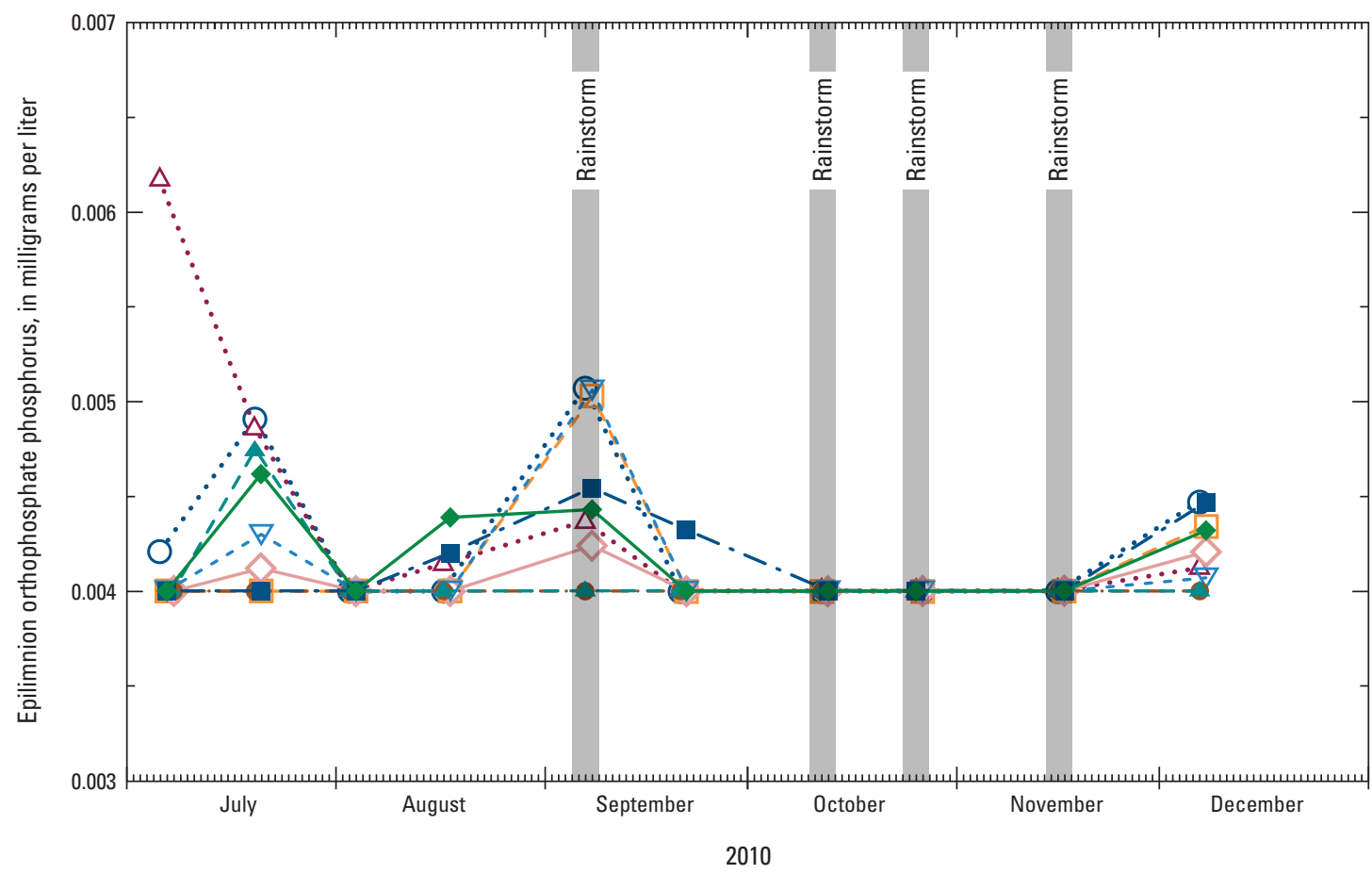

EXPLANATION

- $\cdots \bigcirc \cdots$

Northeast Arm - - - -

Tapps Island

Snag Island $\quad=-\nabla^{-}-$

Lake Inlet : $\quad \cdot$ - : - -

Southeast Arm - - $\mathbf{A}--$

Lake Outlet - -

Dike 2B

Figure 23. Orthophosphate phosphorus concentrations by sample date for Lake Tapps study sites, Washington, July-December 2010.

\section{Fecal-coliform bacteria concentrations}

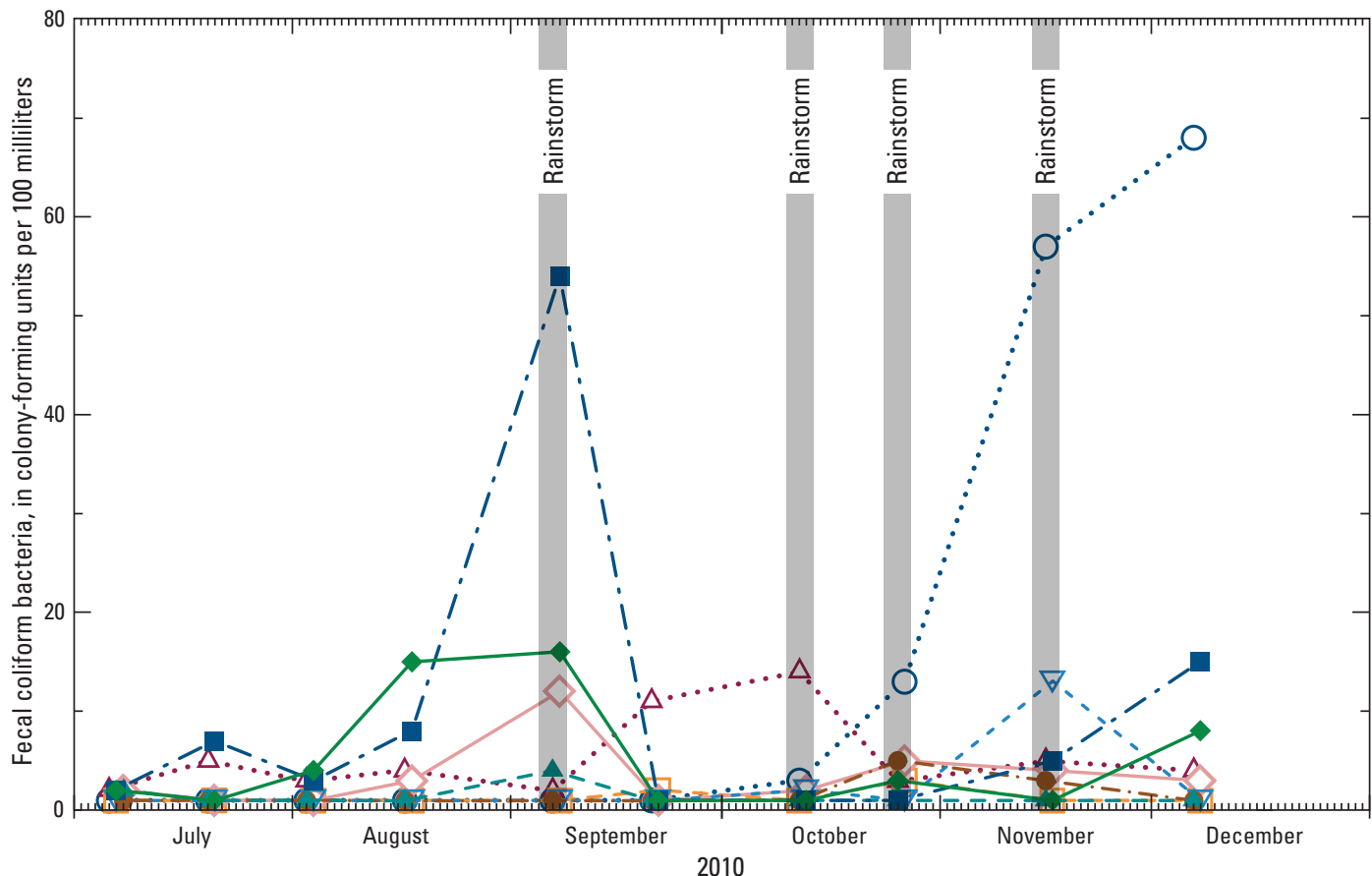

EXPLANATION

Site $\quad$.....

Allan Yorke $\cdots . . \cdot \cdots$

Northeast Arm - - - - -

Tapps Island

Snag Island - - - -

Lake Inlet $\quad . \quad-0 .-$

Southeast Arm - - $\mathbf{A}$ - -

Lake Outlet $\quad-\quad-$

Dike $2 B$

Figure 24. Fecal-coliform bacteria concentrations by sample date for Lake Tapps study sites, Washington, July-December 2010. 


\section{Nitrite-plus-nitrate nitrogen concentrations}

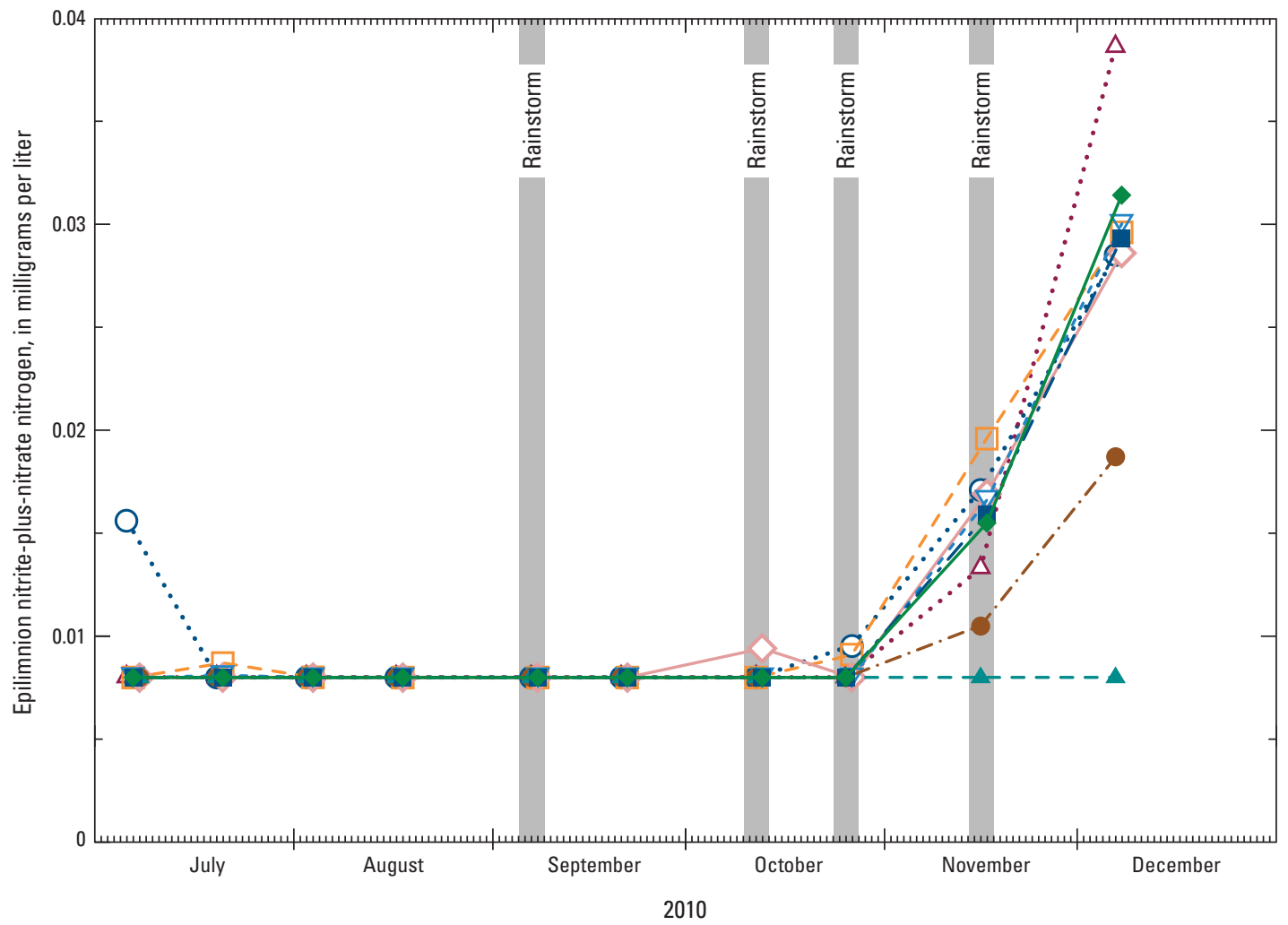

Figure 25. Nitrite-plus-nitrate nitrogen concentrations by sample date for Lake Tapps study sites, Washington, July-December 2010.

\section{Chlorophyll a concentrations}
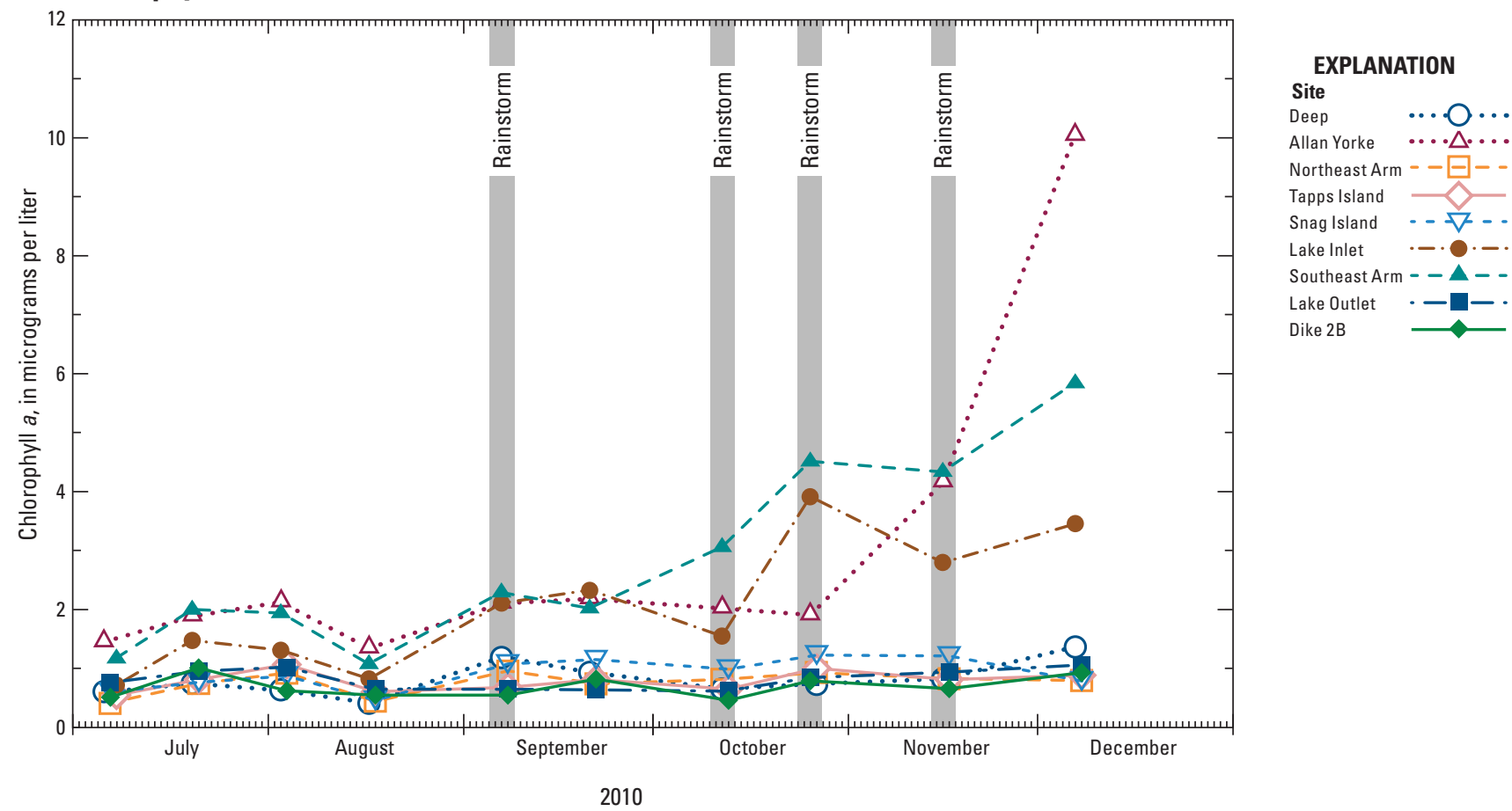

Figure 26. Chlorophyll a concentrations by sample date for Lake Tapps study sites, Washington, July-December 2010. 

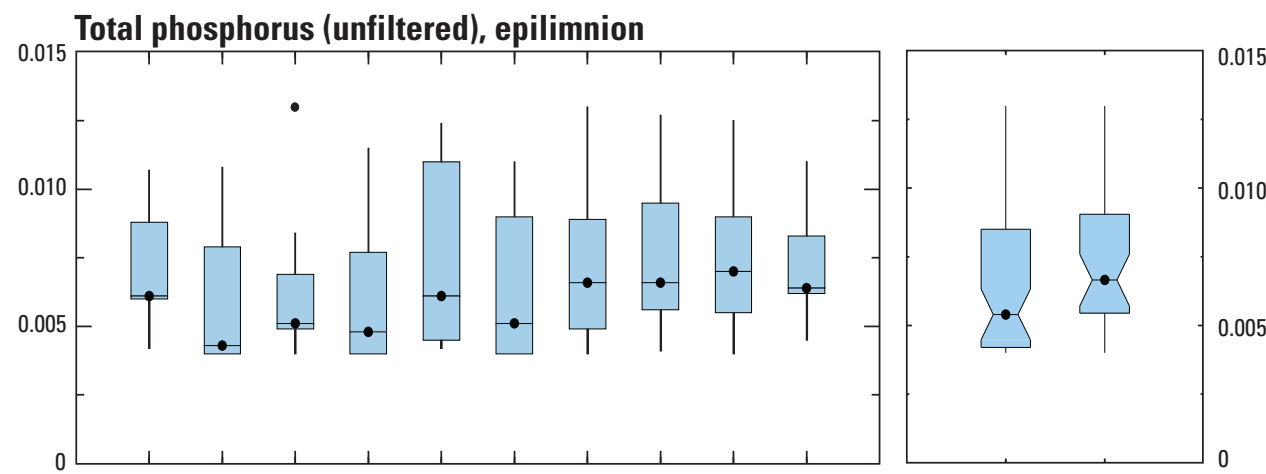

Total phosphorus (unfiltered), hypolimnion
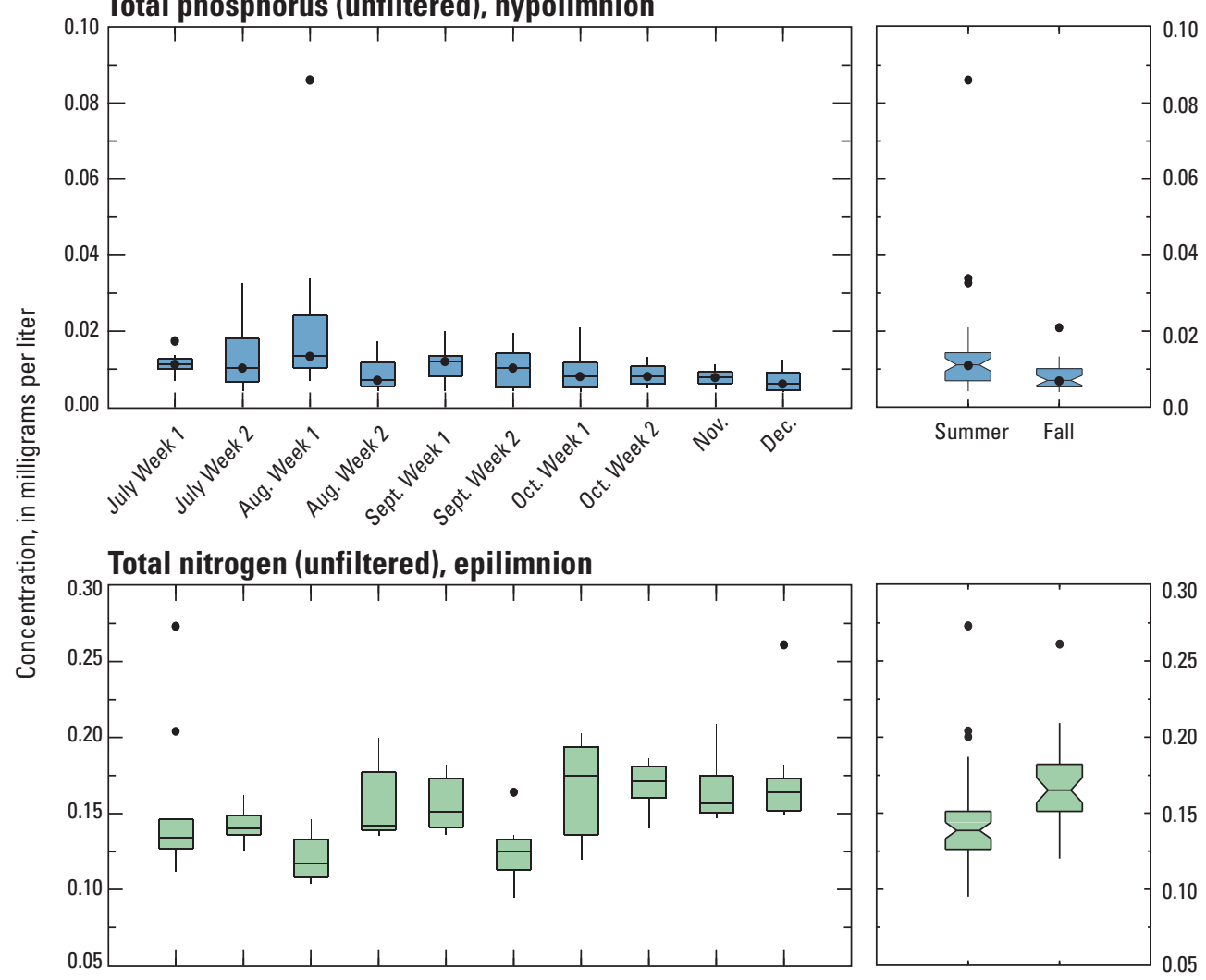

Total nitrogen (unfiltered), epilimnion

Total nitrogen (unfiltered), hypolimnion
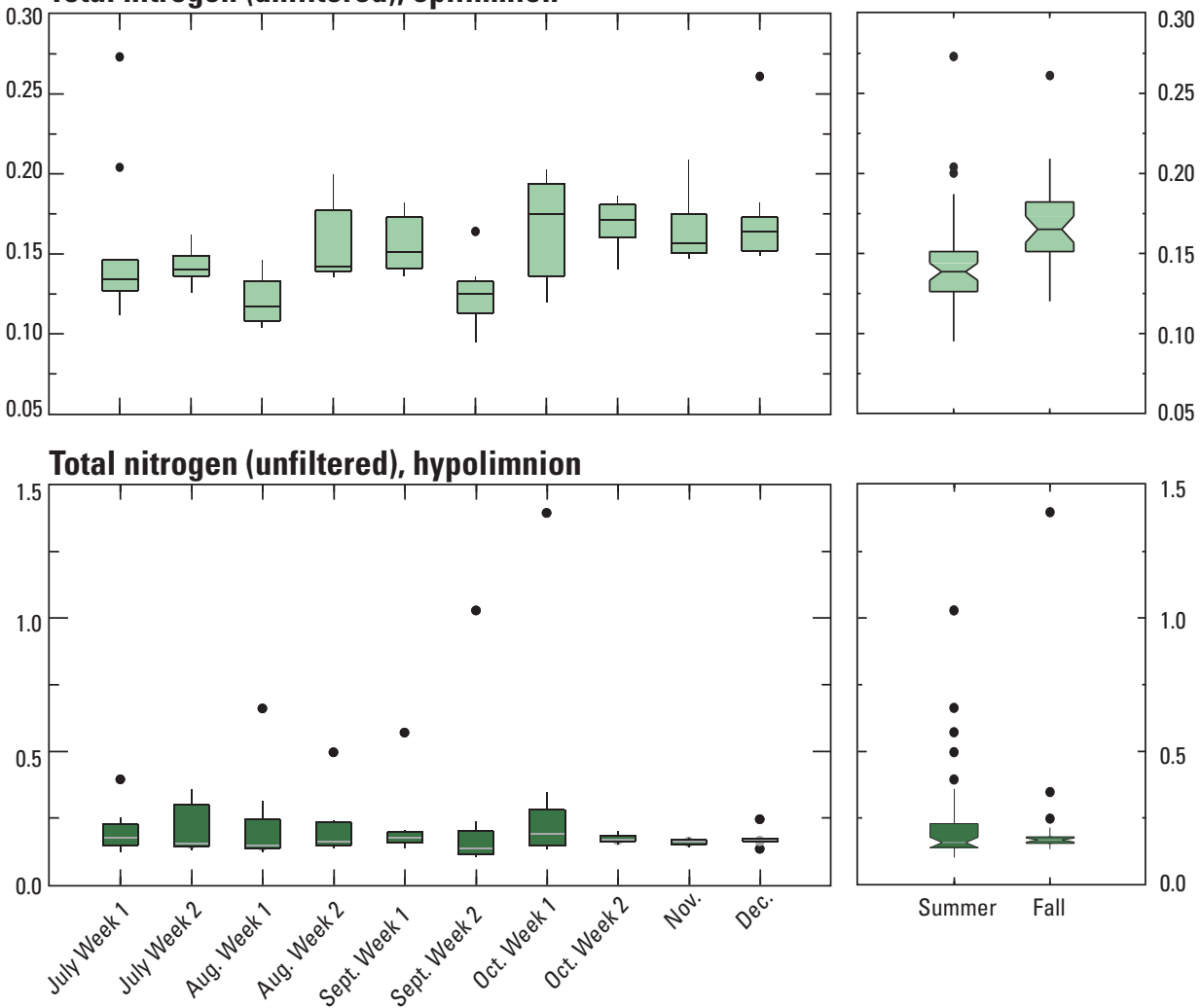

0.05

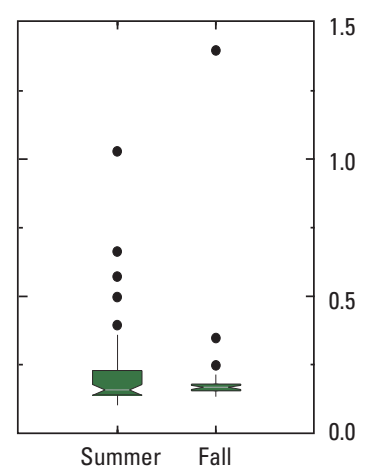

\section{EXPLANATION}

Schematic boxplot

- Outside, $1.5 \mathrm{x}$ interquartile range Upper adjacent

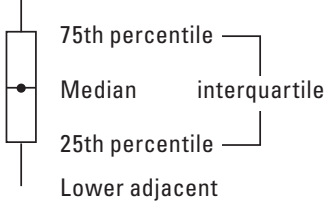

confidence interval, 5 -percent significance level

Figure 27. Total-phosphorus and total-nitrogen concentrations in unfiltered water samples from the epilimnion (near surface) and hypolimnion (near bottom) by month and by season, Lake Tapps, Washington, June-December 2010. Adjacent values are last observation less than 1.5 times the interquartile range beyond the end of the box. Outside values are observations 1.5-3 times the interquartile range. 


\section{Trophic Status}

Assessing the trophic state of a lake is a way of describing the condition of the lake with respect to primary production (plant and algal growth), which among other growth requirements, closely depends on concentrations of the nutrients phosphorus and nitrogen. Lakes with high concentrations of nutrients and abundant plant and algal growth are considered eutrophic. Lakes with low nutrient concentrations and low rates of primary production are called oligotrophic. Mesotrophic lakes have nutrient and productivity levels intermediate to eutrophic and mesotrophic lakes. Eutrophication is a slow, natural aging process for a lake; however, humans can accelerate the eutrophication process by contributing excessive amounts of nutrients to the lake through agriculture, lakeshore disturbance, and other activities (U.S. Environmental Protection Agency, 2009, chap. 5).

Trophic state indexes (Carlson, 1977) and trophic state concentration thresholds (Carlson, 1977; Nürnberg, 1996) use measures of Secchi disk transparency depth, chlorophyll $a$, and total phosphorus to describe a continuum of biological productivity of a lake. The trophic state indexes (TSI) and water-quality measures also are used to group lakes into three basic classes of trophic status. TSIs less than 40 describe the oligotrophic class, 40 to 50 describe the mesotrophic class, and greater than 50 describe the eutrophic class (table 12). Oligotrophic lakes are characterized by clear water (high transparency), low concentrations of chlorophyll $a$ and total phosphorus, and low biological productivity. Mesotrophic lakes have characteristics intermediate to oligotrophic lakes and eutrophic or highly productive lakes. Carlson (1977) recommended using indexes calculated for the summer season for purposes of classification. King County Water and Land Resources also uses average summer values (JuneSeptember) to calculate TSIs for lakes in the Major Lakes Monitoring program (King County Water and Land Resources Division, 2011).

Lake Tapps as a whole generally fits within the oligotrophic classification on the basis of the TSI (table 13) and average water-quality measures of transparency, chlorophyll $a$, and total phosphorus (table 14). TSIs based on transparency suggest potential mesotrophic status at Allan Yorke and Lake Inlet sites and eutrophic status at the Southeast Arm site (table 13). However, because non-algal particulate matter and other factors can affect Secchi disk measurements, the TSIs at these sites using transparency might not be the best descriptor of trophic state . Carlson (1977) cautions the use of Secchi disk transparency depths in lakes containing high amounts of non-algal particulate matter and favors the use of the chlorophyll index during summer and the phosphorus index during spring, autumn, and winter. Chlorophyll $a$ and total phosphorus TSIs indicate oligotrophic conditions at Allan Yorke, Lake Inlet, and Southeast Arm sites; but the TSIs of nearly 40 approach the upper limit of oligotrophic conditions. In addition, average concentrations of total phosphorus at Lake Inlet and Southeast Arm are at Nürnberg's (1996) threshold of $0.01 \mathrm{mg} / \mathrm{L}$, which suggests a slight tendency towards mesotrophic conditions at these two sites during summer (table 14).

Table 12. Lake trophic states and classification ranges for trophic state index, with thresholds for Secchi-disk transparency depths and concentrations of chlorophyll $a$ and total phosphorus (unfiltered water).

[Based on Carlson (1977) and Nürnberg (1996). Potential for algal blooms: Data from the King County Major Lakes Monitoring Program (King County Water and Land Resources Division, 2011). A bbreviations: m, meter; $\mu \mathrm{g} / \mathrm{L}$, microgram per liter; $\mathrm{mg} / \mathrm{L}$, milligram per liter; <, less than; >, greater than]

\begin{tabular}{|c|c|c|c|c|c|}
\hline Lake trophic state & $\begin{array}{l}\text { Carlson trophic } \\
\text { state index }\end{array}$ & $\begin{array}{c}\text { Secchi disk } \\
\text { transparency } \\
\text { (m) }\end{array}$ & $\begin{array}{c}\text { Chlorophyll a } \\
(\mu \mathrm{g} / \mathrm{L})\end{array}$ & $\begin{array}{c}\text { Total } \\
\text { phosphorus } \\
\text { (mg/L) }\end{array}$ & $\begin{array}{c}\text { Potentia } \\
\text { for algal } \\
\text { blooms }\end{array}$ \\
\hline Values thresholds (Carlson, 1977) & & $>4$ & $<2.6$ & $<0.012$ & \\
\hline Values thresholds (Nurnberg, 1996) & & $>4$ & $<3.5$ & $<0.010$ & \\
\hline Values thresholds (Nurnberg, 1996) & & $2-4$ & $3.5-9.0$ & $0.010-0.030$ & \\
\hline Eutrophic & $>50$ & & & & High \\
\hline Values thresholds (Carlson, 1977) & & $<2$ & $>6.4$ & $>0.024$ & \\
\hline Values thresholds (Nurnberg, 1996) & & $<2$ & $>9.0$ & $>0.030$ & \\
\hline
\end{tabular}


Table 13. Summer trophic state indexes for Lake Tapps, Washington, using data collected at nine study sites, July-September 2010.

[Summer is defined for this study as July through September. TSI less than 40 usually considered oligotrophic; 40-50 as mesotrophic and indicated in bold type; and greater than 50 as eutrophic and indicated in bold, italic type (http://www.epa.gov/bioiweb1/aquatic/carlson.html). TSI, 60 - (14.41

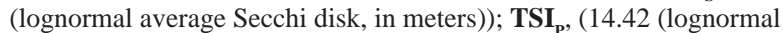
average total phosphorus (unfiltered), in micrograms per liter)) $+4.15 ; \mathbf{T S I}_{\mathrm{c}}$, (9.81 (lognormal average chlorophyll $a$, in micrograms per liter)) +30.6 .

Abbreviation: TSI, trophic state index]

\begin{tabular}{lccc}
\hline \multicolumn{1}{c}{ Site } & $\begin{array}{c}\text { Secchi disk } \\
\text { transparency } \\
\left(\text { TSI }_{\mathbf{s}} \text { ) }\right.\end{array}$ & $\begin{array}{c}\text { Total } \\
\text { phosphorus } \\
\left(\mathbf{T S I}_{\mathbf{p}}\right)\end{array}$ & $\begin{array}{c}\text { Chlorophyll a } \\
\text { (TSI) }\end{array}$ \\
\hline Deep & 33 & 24 & 28 \\
Allan Yorke & $\mathbf{4 6}$ & 36 & 37 \\
Northeast Arm & 35 & 26 & 27 \\
Tapps Island & 34 & 27 & 28 \\
Snag Island & 35 & 30 & 29 \\
Lake Inlet & $\mathbf{4 6}$ & 37 & 34 \\
Southeast Arm & $\mathbf{5 2}$ & 38 & 36 \\
Lake Outlet & 33 & 28 & 28 \\
Dike 2B & 37 & 28 & 27 \\
\hline
\end{tabular}

Ratios of nitrogen to phosphorus (N:P) are reflected in the composition of the phytoplankton community of a lake (Wetzel, 2001). Changes in the ratios over the long term might forecast shifts in the phytoplankton community and the prevalence of the cyanobacteria (King County Water and Land Resources Division, 2003). These N:P ratios are often used in lake studies to indicate which major nutrient is most likely to limit primary production by algae. Typically in freshwater, limitation by phosphorus tends to be more common than limitation by nitrogen (Wetzel, 2001). Carroll and Pelletier (1991) in a study of Lake Sawyer in King County used commonly reported boundaries of greater than 17 by weight as indicative of phosphorus limitation and less than 10 by weight as probable nitrogen limitation. Intermediate ratios suggest either nitrogen or phosphorus (or both) can be limiting (Carroll and Pelletier, 1991). On the basis of concentration ratios for epilimnetic water, primary production in Lake Tapps appears to be phosphorus limited as indicated by ratios greater than 17 at all but 2 study sites (table 14). At the Lake Inlet and Southeast Arm sites, ratios of 15 and 16, respectively, for the summer period suggest either nitrogen or phosphorus (or both) may limit algal growth.

Table 14. Average summer Secchi-disk transparency depths and concentrations of chlorophyll a, total nitrogen, and total phosphorus in unfiltered water from the epilimnion, and ratios of total nitrogen to total phosphorus at Lake Tapps study sites, Washington, JulySeptember 2010.

[Summer is defined as July through September. Values indicating potentially mesotrophic conditions are indicated in bold type. Values indicating potentially eutrophic conditions are indicated in bold, italic type See table 13 for lake trophic state classifications and thresholds for associated parameters by Carlson (1977) and Nürnberg (1996). TN:TP ratios by weight greater than 17 can indicate potential phosphorus limitation; ratios between 10:1 and 17:1 suggest limitation by either nitrogen or phosphorus or co-limitation. A bbreviations: m, meter; $\mu \mathrm{g} / \mathrm{L}$, microgram per liter; mg/L, milligram per liter; TN, total nitrogen, unfiltered water; TP, total phosphorus, unfiltered water]

\begin{tabular}{|c|c|c|c|c|c|}
\hline Site & $\begin{array}{c}\text { Secchi-disk } \\
\text { transparency depth } \\
\text { (m) }\end{array}$ & $\begin{array}{l}\text { Chlorophyll a } \\
\text { ( } \mu \mathrm{g} / \mathrm{L})\end{array}$ & $\begin{array}{l}\text { Total nitrogen } \\
\text { (mg/L) }\end{array}$ & $\begin{array}{l}\text { Total phosphorus } \\
\text { (mg/L) }\end{array}$ & $\begin{array}{c}\text { TN:TP ratio } \\
\text { (mg/L nitrogen: } \\
\text { mg/L phosphorus) }\end{array}$ \\
\hline Allan Yorke & 2.64 & 1.85 & 0.16 & 0.009 & 19 \\
\hline Northeast Arm & 5.60 & 0.71 & 0.13 & 0.004 & 29 \\
\hline Tapps Island & 5.98 & 0.76 & 0.12 & 0.005 & 26 \\
\hline Southeast Arm & 178 & 1.75 & 0.16 & 0.011 & 16 \\
\hline Lake Outlet & 6.39 & 0.78 & 0.16 & 0.005 & 32 \\
\hline Dike 2B & 4.95 & 0.68 & 0.12 & 0.005 & 25 \\
\hline
\end{tabular}




\section{Organic Chemical Screening}

Of the 250 organic chemicals analyzed in water samples from each of the three sites, the great majority were not detected in concentrations greater than laboratory reporting levels (appendix G). A total of 14 compounds were detected in trace amounts at one or more of the three lake sites (table 15). In samples from one or more of the three sites, 6 of these 14 compounds were verified to be present, but in concentrations too small to quantify. These compounds included camphor, DEET, benzophenone, isophorone, methyl salicylate, and tris-(dichloroisopropyl)-phosphate. These compounds are shown in table 15 and in the NWIS database with the code of "M". Although these compounds were not quantified, they are included here in the list of 14 compounds with detections. A sample from the Allan Yorke site had 9 detections and a sample from the Snag Island site had 10 detections of compounds mostly belonging to the group of wastewater indicator chemicals. Compounds detected (or with verified presence) in samples at all three sites included the herbicide 2,4-D, the insecticide and mosquito repellant DEET, the herbicide used for milfoil eradication fluridone, and the herbicide prometon. The largest concentrations of these compounds were in the samples from the Allan Yorke site; the lowest concentrations were from the Lake Outlet site.

Table 15. Organic compounds detected in water samples collected at Allan Yorke (fig. 4, map No. L2), Snag Island (map No. L5), and Lake Outlet (map No. L8) sites on Lake Tapps, Washington, September 21-22, 2010.

[Abbreviations: NWQL, National Water Quality Laboratory; $\mu \mathrm{g} / \mathrm{L}$, microgram per liter; <, less than; M, presence of analyte verified, but not quantified; e, estimated; DEET, N,N-diethyl-meta-toluamide; HHCB, Hexahydrohexamethylcyclopentabenzopyran; UV, ultraviolet]

\begin{tabular}{|c|c|c|c|c|c|}
\hline \multirow{2}{*}{$\begin{array}{c}\text { Chemical } \\
\text { (NWOL schedule') }\end{array}$} & \multirow{2}{*}{$\begin{array}{l}\text { Parameter } \\
\text { code }\end{array}$} & \multirow{2}{*}{ Use $^{1}$} & \multicolumn{3}{|c|}{ Concentration $(\mu \mathrm{g} / \mathrm{L})$} \\
\hline & & & Site L2 & Site L5 & Site L8 \\
\hline 2,4-D (2060) & 39732 & Herbicide & 0.2 & 0.17 & 0.16 \\
\hline Camphor (1433) & 62070 & Flavor, odorant, ointments & $<0.044$ & $\mathrm{M}$ & $<0.044$ \\
\hline DEET (1433) & 62082 & Insecticide, mosquito repellant & M & M & M \\
\hline Desulfinylfipronil (2033) & 62170 & Degradate & $\mathrm{e} 0.006$ & $<0.012$ & $<0.012$ \\
\hline Diuron (2060) & 49300 & Herbicide & $<0.04$ & $\mathrm{e} 0.01$ & $\mathrm{e} 0.01$ \\
\hline Fluridone (2033 add-on) & 65216 & Herbicide, Eurasian watermilfoil control & 2.09 & 1.02 & 0.308 \\
\hline Prometon (2033) & 04037 & Herbicide & 0.01 & 0.01 & 0.01 \\
\hline 1,7-Dimethylxanthine (2080) & 62030 & Metabolite of caffeine & $<0.1$ & $\mathrm{e} 0.02$ & $<0.1$ \\
\hline Acetaminophen (2080) & 62000 & Analgesic & $<0.12$ & $\mathrm{e} 0.037$ & $<0.12$ \\
\hline Benzophenone (1433) & 62067 & Additive in perfumes, soaps & M & $<0.1$ & $<0.1$ \\
\hline HНCB (1433) & 62075 & Musk fragrance (persistent in groundwater) & 0.1 & $<0.1$ & $<0.1$ \\
\hline Isophorone (1433) & 34409 & Solvent & M & $\mathrm{M}$ & $<0.1$ \\
\hline Methyl salicylate (1433) & 62081 & Liniment, food, beverage, UV-absorbing lotion & $<0.044$ & $\mathrm{M}$ & $<0.044$ \\
\hline $\begin{array}{l}\text { Tris (dichloroisopropyl) } \\
\text { phosphate (1433) }\end{array}$ & 62088 & Flame retardant & M & $<0.2$ & $<0.2$ \\
\hline
\end{tabular}

\footnotetext{
${ }^{1}$ See appendix C, Organic Schedules for lists of all compounds by analytical schedule, laboratory reporting levels, and references on the uses listed
} for the chemicals. 


\section{Summary}

The White River and Lake Tapps are part of a hydropower system completed in 1911-12. The system begins with a diversion dam on the White River that routes a portion of White River water into the southeastern end of Lake Tapps, which functioned as a storage reservoir for power generation. The stored water passed through the hydroelectric facilities at the northwestern end of the lake and returned to the White River through the powerhouse tailrace. Power generation ceased in January 2004, which altered the hydrology of the system primarily by reduced volumes of diverted water. Inflows into the lake, which previously averaged 890 cubic feet per second $\left(\mathrm{ft}^{3} / \mathrm{s}\right)$ decreased to about $120 \mathrm{ft}^{3} / \mathrm{s}$, and average flows in the White River downstream of the diversion dam (Diversion Reach) increased from 579 to 1,270 ft³ 3 s. This study conducted from May to December 2010 created a set of baseline data collected under a new flow regime for Lake Tapps and selected reaches of the White River; the White River Canal, which delivers water to Lake Tapps; and the Lake Tapps Diversion (Tailrace), which returns water to the White River at Dieringer.

Discrete water samples were collected from the Headworks, White River Canal at 218th Street E (Inflow), and Tailrace sites. Three sites were equipped for continuous recording of water-quality data: the Headworks site near the diversion dam, the Tailrace site, and the R-Street site in the Diversion Reach of the river.

Nine lake-study sites were distributed throughout Lake Tapps to include a range of physical and nearshore conditions. The Deep site in the main part of the western basin is the deepest of the nine sites at about 27 meters (m). The Southeast Arm site was the shallowest at a depth of about $3 \mathrm{~m}$. Water depths at the other sites ranged from about 5 to $15 \mathrm{~m}$. Water samples from the study sites were measured for physical and water-quality properties and analyzed for turbidity, concentrations of nutrients, suspended solids, and fecal-coliform bacteria. Samples from the lake sites also were analyzed for concentrations of chlorophyll $a$ and organic chemicals.

The samples indicated that the water at the Headworks, Inflow, and Tailrace sites was generally turbid, warm, chemically dilute, and well-oxygenated. Exceptions occurred at sites when flow to the White River Canal was suspended or when little or no flow was released from Lake Tapps. In these cases, water from the Headworks, Inflow, and Tailrace sites was warmer, and more likely to be affected by the biological processes that influence nutrients, $\mathrm{pH}$, and dissolved oxygen. The quality of physical properties and concentrations in water measured continuously at the Headworks, R-Street, and Tailrace sites generally was good and met the freshwater criteria designated by the Washington State Department of Ecology for recreational uses and aquatic life uses, with several exceptions. The 7-day average of daily maximum temperatures (7-DADMax) was greater than the freshwater aquatic life criterion of 16 degrees Celsius $\left({ }^{\circ} \mathrm{C}\right)$ for core summer salmonid habitat for 6 days at the Headworks site and 37 days at the R-Street site during the study. In addition, 7-DADMax temperatures were greater than the $13^{\circ} \mathrm{C}$ criterion for spawning, rearing, and incubation on 6 days at the Headworks site and 20 days at the R-Street site. The freshwater aquatic life criterion for dissolved oxygen of $9.5 \mathrm{mg} / \mathrm{L}$ for core summer salmonid habitat was not met at the Headworks and R-Street sites for periods of time in July and August 2010. Exceptions also occurred at the Headworks site for measurements of $\mathrm{pH}$, which were greater than the freshwater aquatic life upper limit of $8.5 \mathrm{pH}$ units during July 2010. Aquatic life $\mathrm{pH}$ criteria also were not met at the Tailrace site during June, July, and August 2010, when pH was greater than $8.5 \mathrm{pH}$ units, and during August 2010 when $\mathrm{pH}$ decreased to less than $6.5 \mathrm{pH}$ units.

Lake Tapps water near the surface was relatively clear as indicated by low turbidity values (medians generally less than about 1.7 ratio-corrected nephelometric turbidity units) and relatively high Secchi disk depths (medians $4.9 \mathrm{~m}$ or more) at most sites. The clearest water of the nine lake sites was at the Deep site with a median Secchi disk measurement of $6.05 \mathrm{~m}$, which is as much as six times the historical (1974-97) transparency depth measurements for this location . At three sites in the southern end of the lake (Allan Yorke, Lake Inlet, and Southeast Arm), the water was more turbid (median turbidities as high as 3.04 ratio-corrected nephelometric turbidity units) and less transparent (median Secchi disk transparencies of $2.61 \mathrm{~m}$ or less).

Water of the epilimnion (or near the surface) at all sites generally was warm yet well oxygenated. Median water temperatures were about $18.2-18.9^{\circ} \mathrm{C}$ and maximums were from $22.9-25.0^{\circ} \mathrm{C}$. Median dissolved oxygen concentrations in the epilimnion were greater than 8.42 milligrams per liter (mg/L) and minimums generally were not less than $7.4 \mathrm{mg} / \mathrm{L}$.

By early July 2010, weak thermal stratification developed at most sites into at least a warm surface layer overlying a small thermocline. Lake Inlet, Southeast Arm, and Dike 2B sites did not thermally stratify during this study. A well-defined hypolimnion developed below the thermocline only at the Deep site. With the development of thermal stratification, hypolimnion water became anoxic at several sites (Deep, Tapps Island, Snag Island, and Lake Outlet). By late September 2010 at the Deep site, an anoxic layer about $15 \mathrm{~m}$ thick had formed in the hypolimnion. Mixing during autumn overturn in late November 2010 re-oxygenated the water column of all sites with about 10-12 mg/L of dissolved oxygen.

On the basis of $\mathrm{pH}$ and specific conductance measurements, Lake Tapps water is $\mathrm{pH}$ neutral and chemically dilute. Median $\mathrm{pH}$ values for water in the epilimnion and hypolimnion ranged from 6.84 to $7.64 \mathrm{pH}$ units and maximums did not exceed $7.8 \mathrm{pH}$ units at any site. Median specific conductance typically was less than 70 microsiemens per centimeter at $25^{\circ} \mathrm{C}$ for the epilimnion and the hypolimnion. 
Concentrations of total suspended solids throughout the lake were low with values typically less than $10 \mathrm{mg} / \mathrm{L}$. Median concentrations in samples from the epilimnion were less than the laboratory reporting level of $1.1 \mathrm{mg} / \mathrm{L}$ at six of nine study sites. Median concentrations were highest at the Southeast Arm site with $3.6 \mathrm{mg} / \mathrm{L}$ for the epilimnion and $3.8 \mathrm{mg} / \mathrm{L}$ for the hypolimnion. At the Deep site, total suspended solids concentrations in the hypolimnion were as high as $30 \mathrm{mg} / \mathrm{L}$ depending on sample depth.

The microbial quality of the lake water at the nine sampling sites is considered excellent for the purposes of this study in that 24 percent of samples were negative for fecal-coliform bacteria. Of the samples with detections, 60 percent had concentrations of 5 colony-forming units, or less, per 100 milliliters. All samples positive for fecalcoliform bacteria during the study had concentrations that would meet the Washington State Department of Ecology single-sample freshwater criterion for extraordinary primary contact recreation of less than 100 colony-forming units per 100 milliliters (CFU/100 mL).

Nutrient concentrations in Lake Tapps were low and certain forms of nitrogen and phosphorus were often not detected at concentrations greater than the laboratory method detection levels. Median concentrations of total nitrogen (unfiltered water) ranged from about $0.14 \mathrm{mg} / \mathrm{L}$ (Deep, Tapps Island, and Dike 2B) to about $0.18 \mathrm{mg} / \mathrm{L}$ (Allan Yorke and Lake Inlet). Median concentrations of total phosphorus (unfiltered water) in the epilimnion ranged from $0.004 \mathrm{mg} / \mathrm{L}$ (Deep and Northeast Arm) to $0.011 \mathrm{mg} / \mathrm{L}$ (Southeast Arm).

At most of the sites and in most of the samples from the epilimnion, total phosphorus concentrations were less the Washington State Department of Ecology phosphorus criterion of $0.01 \mathrm{mg} / \mathrm{L}$ for maintaining oligotrophic conditions. A few samples from the epilimnion at Allan Yorke and Lake Inlet had concentrations greater than the criterion, yet they were still well below the Washington State Department of Ecology action value of $0.02 \mathrm{mg} / \mathrm{L}$ for preserving mesotrophic conditions. At the Southeast Arm site, all sample concentrations except one exceeded $0.01 \mathrm{mg} / \mathrm{L}$, but none was greater than $0.02 \mathrm{mg} / \mathrm{L}$

Chlorophyll $a$ concentrations were low with median concentrations of 2.16 micrograms per liter (mg/L) or less. The Dike 2B site had the lowest concentration of the nine sites with a median of $0.64 \mathrm{mg} / \mathrm{L}$. All concentrations but one were well below the Oregon Department of Environmental Quality action level of $10 \mathrm{mg} / \mathrm{L}$ to identify potential nuisance phytoplankton growth in natural lakes that thermally stratify and $15 \mathrm{mg} / \mathrm{L}$ in lakes and reservoirs that do not stratify.

Rainfall, particularly an intense rainstorm in early September with more than 1.6 inches of rain over 3 days, may have resulted in temporary increases in epilimnion concentrations of total suspended solids, orthophosphate phosphorus, and fecal-coliform bacteria at several sites. Conversely, concentrations of nitrite-plus-nitrate nitrogen and chlorophyll $a$ did not respond to the summer rain events and remained nearly constant near laboratory method detection levels.

With the onset of autumn, epilimnion concentrations of several constituents, including nitrite-plus-nitrate nitrogen and chlorophyll $a$ generally increased. At the Deep site, November concentration of fecal-coliform bacteria of 57 CFU/100 mL and December concentration of 68 CFU/100 $\mathrm{mL}$ appeared to coincide with autumn rain events and lake overturn. Nitrite-plus-nitrate nitrogen concentrations increased in November and December at all sites except at the Southeast Arm site. Concentrations of chlorophyll $a$ also increased during October-December with one value as high as $10 \mathrm{mg} / \mathrm{L}$ (Allan Yorke).

Using the Carlson Trophic-Status Index and average measures of transparency, chlorophyll $a$, and total phosphorus data from this study, Lake Tapps generally fits within the oligotrophic classification, but with a few circumstances bordering on mesotrophy. Although chlorophyll $a$ and total phosphorus TSIs indicate oligotrophic conditions at the Allan Yorke, Lake Inlet, and Southeast Arm sites, the TSIs of nearly 40 approach the upper limit of oligotrophic conditions. In addition, average concentrations of total phosphorus at Lake Inlet and Southeast Arm are at Nürnberg's (1996) threshold concentration of $0.01 \mathrm{mg} / \mathrm{L}$, which suggests a very slight tendency towards mesotrophic conditions at these two sites during summer.

Primary production in Lake Tapps as a whole appears to be phosphorus-limited as indicated by ratios of nitrogento-phosphorus concentrations of greater than 17. At the Lake Inlet and Southeast Arm sites, however, ratios of 15 and 16, respectively, suggest either nitrogen or phosphorus (or both) may limit algal growth.

Water samples collected at three sites (Allan Yorke, Snag Island, Lake Outlet) were screened for the presence of more than 250 organic chemicals with the great majority not detected at concentrations greater than laboratory reporting levels. A total of 14 compounds were detected in trace amounts (or determined to be present) at one or more of the three sites. The Allan Yorke site had 9 detections and the Snag Island site had 10 detections of compounds mostly belonging to the group of wastewater indicator chemicals. Compounds detected (or with verified presence) at all three sites included the herbicide 2,4-D, the insecticide and mosquito repellant DEET, the herbicide used for milfoil eradication fluridone, and the herbicide prometon. The largest concentrations of these compounds were in the samples from the Allan Yorke site; the lowest concentrations were from the Lake Outlet site. 


\section{Acknowledgments}

Michael Gagliardo (Cascade Water Alliance) provided background and historical information on the operation of the White River-Lake Tapps system during power-generating years, and timely updates on construction and maintenance activities of the diversion dam, canal, and flumes. Char Naylor (Puyallup Tribe of Indians) and Nancy Rapin (Muckleshoot Indian Tribe), and Dr. Eugene Welch (University of Washington, professor emeritus) provided information and perspective on previous studies of water quality and hydrology for the White River and Lake Tapps. The authors appreciate the comments and suggestions provided by these individuals for this report. The authors also wish to thank USGS hydrologists and technicians who served as certified boat operators and who provided critical assistance in the field and laboratory —Chris Curran, Greg Justin, Pete Laird, C.G. Laird, Patrick Moran, David Steele, Steve Sumioka, Jim Tilque, and students, Brietta Carter and Kelsey Opsal.

\section{References Cited}

American Public Health Association, American Water Works Association, and Water Environment Federation, 1998, Standards methods for the examination of water and wastewater: Washington D.C., American Public Health Association, 20th edition, various pagination.

American Society for Testing and Materials, 2007, D 3977-97 (2007), Standard test method for determining sediment concentration in water samples: Annual Book of Standards, Water and Environmental Technology, v. 11.02, p. 389394., accessed February 17, 2012 at http://www.astm.org/ Standards/D3977.htm.

Anderson, C.A., 2005, Turbidity (ver. 2.1): U.S. Geological Survey Techniques of Water-Resources Investigations, book 9, chap. A6, sec. 6.7. (Also available at http://water. usgs.gov/owq/FieldManual/Chapter6/6.7 contents.html.)

Arar, E.J., and Collins G.B., 1997, U.S. Environmental Protection Agency Method 445.0, In vitro determination of chlorophyll $a$ and pheophytin $a$ in marine and freshwater algae by fluorescence, Revision 1.2: U.S. Environmental Protection Agency, National Exposure Research Laboratory, Office of Research and Development, accessed December 20, 2011, at http://www.epa.gov/nerlcwww/ m445 0.pdf.

Bell-McKinnon, M., 2002, Water quality assessments of volunteer-monitored lakes within Washington State, 19981999: Washington State Department of Ecology, Publication No. 02-03-019, 15 p., accessed December 20, 2011, at http://www.ecy.wa.gov/biblio/0203019.html.
Bortleson, G.C., Dion, N.P., McConnell, J.B., and Nelson, L.M., 1976, Reconnaissance data on lakes in Washington: Washington State Department of Ecology Water-Supply Bulletin, no. 43, v. 3, 259 p.

Carlson, R.E., 1977, A trophic state index for lakes: Limnology and Oceanography, v. 22, no. 2, p. 361-369.

Carroll, J.V., and Pelletier, G.J., 1991, Diagnostic study of Lake Sawyer, King County, Washington: Washington State Department of Ecology, Publication No. 91-e05, 150 p.

Cascade Water Alliance, 2011, Milfoil: web page, accessed December 20, 2011, at http://cascadewater.org/lake tapps milfoil.php.

Ebbert, J.C., 2002, Concentrations of dissolved oxygen in the lower Puyallup and White Rivers, Washington, August and September 2000 and 2001: U.S. Geological Survey WaterResources Investigations Report 02-4146, 35 p.

Ebbert, J.C., 2003, Water temperature, specific conductance, $\mathrm{pH}$, and dissolved oxygen concentrations in the lower White River and the Puyallup River estuary, Washington, AugustOctober 2002: U.S. Geological Survey Water-Resources Investigations Report 03-4177, 21 p.

Furlong, E.T., Anderson, B.D., Werner, S.L., Soliven, P.P., Coffey, L.J., and Burkhardt, M.R., 2001, Methods of analysis by the U.S. Geological Survey National Water Quality Laboratory-Determination of pesticides in water by graphitized carbon-based solid-phase extraction and high-performance liquid chromatography/mass spectrometry: U.S. Geological Survey Water-Resources Investigations Report 01-4134, 73 p.

Furlong, E.T., Werner, S.L., Anderson, B.D., and Cahill, J.D., 2008, Determination of human-health pharmaceuticals in filtered water by chemically modified styrenedivinylbenzene resin-based solid-phase extraction and highperformance liquid chromatography/mass spectrometry: U.S. Geological Survey Techniques and Methods, book 5, sec. B, chap. B5, 56 p. (Also available at http://pubs.usgs. gov/tm/tm5b5/.)

Gibs, Jacob, Wilde, F.D., and Heckathorn, H.A., 2007, Use of multiparameter instruments for routine field measurements (ver. 1.1): U.S. Geological Survey Techniques of WaterResources Investigations, book 9, chap. A6, sec. 6.8. (Also available at http://pubs.water.usgs.gov/twri9A/).

Hallock, D., 2006, Lake Tapps (Pierce County) monitoringFinal data report: Washington State Department of Ecology, Publication No. 06-03-006, 26 p. plus appendixes, accessed December 20, 2011, at http://www.ecy.wa.gov/ biblio/0603006.html. 
King County Water and Land Resources Division, 2003, SWAMP_-Sammamish/Washington analysis and modeling program—Lake Washington existing conditions report: King County Department of Natural Resources and Parks, 209 p., accessed January 3, 2012, at http://your.kingcounty. gov/dnrp/library/2003/kcr1479.pdf.

King County Water and Land Resources Division, 2011, Major lakes monitoring-Trophic State Index: King County web page, accessed December 20, 2011, at http://green. kingcounty.gov/lakes/TSI.aspx.

Lindley, C.E., Stewart, J.T., and Sandstrom, M.W., 1996, Determination of low concentrations of acetochlor in water by automated solid-phase extraction and gas chromatography with mass selective detection: Journal of AOAC International, v. 79, no. 4, p. 962-966.

Madsen, J.E., Sandstrom, M.W., and Zaugg, S.D., 2003, Methods of analysis by the U.S. Geological Survey National Water Quality Laboratory-A method supplement for the determination of fipronil and degradates in water by gas chromatography/mass spectrometry: U.S. Geological Survey Open-File Report 02-462, 11 p. (Also available at http://nwql.usgs.gov/Public/pubs/OFR02-462/OFR02-462. html.)

Maloney, T.J., ed., 2005, Quality Management System, U.S. Geological Survey National Water Quality Laboratory: U.S. Geological Survey Open-File Report 2005-1263, version 1.3, 93 p. (Also available at http://pubs.usgs.gov/ of/2005/1263/.)

Moore, Allen, and Hicks, Mark, 2004, Nutrient criteria development in Washington State-Phosphorus: Washington State Department of Ecology, Publication No. 04-10-033, 56 p., accessed December 20, 2011, at http://www.ecy.wa.gov/biblio/0410033.html.

Myers, D.N., Stoeckel, D.M., Bushon, R.N., Francy, D.S., and Brady, A.M.G., 2007, Fecal indicator bacteria (ver. 2.0): U.S. Geological Survey Techniques of Water-Resources Investigations, book 9, chap. A7, sec. 7.1. (Also available at http://pubs.water.usgs.gov/twri9A7/.)

National Climatic Data Center, 2010, Climatological Data Annual Summary—Washington, 2010: National Climatic Data Center, v. 114, no. 13, 36 p., accessed March 2, 2011, at http://www1.ncdc.noaa.gov/pub/orders/IPS-027B997F315D-493D-A2B8-E2D411E52954.pdf.)

National Marine Fisheries Service, 1999, Final RuleEndangered and threatened species; threatened status for three Chinook salmon evolutionarily significant units (ESUs) in Washington and Oregon, and endangered for one Chinook salmon ESU in Washington: Federal Register, v. 64, no. 56, p. 14308.
National Marine Fisheries Service, 2007, Final RuleEndangered and threatened species; final listing determination for Puget Sound steelhead: Federal Register, v. 72, no. 91, p. 26722.

National Oceanic and Atmospheric Administration, 2011, Precipitation from National Climatic Data Center, accessed December 20, 2011 at http://www7.ncdc.noaa.gov/IPS/ coop/coop.html.

Nürnbergm, G.K., 1996, Trophic state of clear and colored, soft- and hardwater lakes with special consideration of nutrients, anoxia, phytoplankton and fish: Journal of Lakes and Reservoir Management, v. 12, no. 4, p. 432-447.

Oregon State Archives, 2003, Oregon Administrative Rule 340-041-0019-Nuisance Phytoplankton Growth: Oregon Department of Environmental Quality, accessed December 21, 2011, at http://arcweb.sos.state.or.us/pages/ rules/oars 300/oar 340/340 041.html.

Patton, C.J., and Kryskalla. J.R., 2003, Methods of analysis by the U.S. Geological Survey National Water Quality Laboratory-Evaluation of alkaline persulfate digestion as an alternative to kjeldahl digestion for determination of total and dissolved nitrogen and phosphorus in water: U.S. Geological Survey Water-Resources Investigations Report 03-4174, 33 p., accessed December 21, 2011, at http://nwql.usgs.gov/Public/pubs/WRIR03-4174/WRIR034174.html.

Pierce County Public Works and Utilities, 2007, White River basin plan characterization report: Pierce County Public Works and Utilities Water Programs Division, 246 p., accessed December 21, 2011, at http://www.co.pierce. wa.us/pc/services/home/environ/water/ps/watershed/ whiterivermain.htm.

Reese, O.G., 2010, Water quantity and water quality analyses for the Lake Tapps water right applications: Prepared for Washington State Department of Ecology, Aspect Consulting Project Number 020071A-001-03, 166 p., Seattle, Washington, accessed December 21, 2011, at https://fortress.wa.gov/ecy/wrx/wrx/fsvr/ecylcyfsvrxfile/ WaterRights/ScanToWRTS/hq4/06709557.pdf.

Sandstrom, M.W., Stroppel, M.E., Foreman, W.T., and Schroeder, M.P., 2001, Methods of analysis by the U.S. Geological Survey National Water Quality LaboratoryDetermination of moderate-use pesticides and selected degradates in water by $\mathrm{C}-18$ solid-phase extraction and gas chromatography/mass spectrometry: U.S. Geological Survey Water-Resources Investigations Report 01-4098, 70 p., accessed December 21, 2011, at http://nwql.usgs.gov/ Public/pubs/WRIR01-4098.pdf. 
Sea-Bird Electronics, Inc., 2010, Sea-Bird application notes 18-1 and 18-2: accessed November 14, 2011, at http://www.seabird.com/application notes/an18 2.htm and http://www.seabird.com/application notes/an18 1.htm.

Sea-Bird Electronics, Inc., 2011, SEASOFT V2-SBE Data Processing - CTD data processing and plotting software for Windows 2000/XP: Bellevue, Wash., Sea-Bird Electronics, Inc, accessed December 21, 2011, at http://www.seabird. com/pdf documents/manuals/SBEDataProcessing 7.21e. pdf.

Smith, K.A., Parsons, J., and Hallock, D., 2000, Water quality assessments of selected lakes within Washington State1997: Washington State Department of Ecology, Publication No. 00-03-009, 51 p.

Sumioka, S.S. and Dion, N.P., 1985, Trophic classification of Washington lakes using reconnaissance data: Washington State Department of Ecology Water-Supply Bulletin No. 57, 320 p., accessed March 18, 2010, at http://www.ecy.wa.gov/ programs/eap/wsb/wsb All.html\#p57.

U.S. Environmental Protection Agency, 1986, Ambient water quality criteria for bacteria—1986: U.S. Environmental Protection Agency, Office of Water, publication EPA440/584-002, 22 p.

U.S. Environmental Protection Agency, 1993, Method 365.1 Determination of phosphorus by semi-automated colorimetry, revision 2.0, methods for the determination of inorganic substances in environmental samples: U.S Environmental Protection Agency, 17 p., accessed December 21, 2011 at http://water.epa.gov/scitech/ methods/cwa/bioindicators/upload/2007 0710 methods method_365_1.pdf.

U. S. Fish and Wildlife Service, 1999, Final RuleEndangered and threatened wildlife and plants; determination of threatened status for bull trout in the coterminous United States: Federal Register, v. 64, no. 210, p. 58910 .

U.S. Geological Survey, 2006, Collection of water samples (ver. 2.0): U.S. Geological Survey Techniques of WaterResources Investigations, book 9, chap. A4. (Also available at http://pubs.water.usgs.gov/twri9A4/.)

U.S. Geological Survey, 2010, Branch of Quality Systems: accessed November 14, 2011, at http://bqs.usgs.gov/.

U.S. Geological Survey, 2011a, National Water Information System (NWISWeb)-USGS water data for Washington: U.S. Geological Survey database, accessed December 21, 2011, at http://waterdata.usgs.gov/wa/nwis/.
U.S. Geological Survey, 2011b, Ohio Water Microbiology Laboratory-Quality assurance/quality control manual, table 6: web page, accessed December 21, 2011 at http:// oh.water.usgs.gov/micro qaqc fecal indicator.htm.

U.S. Geological Survey, 2011c, White River Basin and Lake Tapps water quality_Data: U.S. Geological Survey website, accessed December 23, 2011, at http://wa.water. usgs.gov/projects/laketapps/data.htm.

U.S. Geological Survey, variously dated, National field manual for the collection of water-quality data: U.S. Geological Survey Techniques of Water-Resources Investigations, book 9, chaps. A1-A9. (Also available at http://pubs.water. usgs.gov/twri9A.)

Wagner, R.J., Boulger, R.W., Jr., Oblinger, C.J., and Smith, B.A., 2006, Guidelines and standard procedures for continuous water-quality monitors-Station operation, record computation, and data reporting: U.S. Geological Survey Techniques and Methods 1-D3, 51 p. (attachments). (Also available at http://pubs.water.usgs.gov/tm1d3.)

Wagner, R.J., Kimbrough, R.A., and Turney, G.L., 2007, Quality-assurance plan for water-quality activities in the U.S. Geological Survey Washington Water Science Center: U.S. Geological Survey Open-File Report 2007-1307, 48 p. (Also available at http://pubs.usgs.gov/of/2007/1307/.)

Washington State Department of Ecology, 2006 [2011], Waters requiring supplemental spawning and incubation protection for salmonid species: Washington State Department of Ecology, Publication No. 06-10-038, 42 p., accessed December 21, 2011, at http://www.ecy.wa.gov/ biblio/0610038.html.

Washington State Department of Ecology, 2009, 2008 Water quality assessment and 303(d) list: Washington State Department of Ecology, accessed December 21, 2011, at http://www.ecy.wa.gov/programs/wq/303d/2008/index.html.

Washington State Department of Ecology, 2010a, Investigators report for Surface Water Permit S2-29920: Washington State Department of Ecology, 106 p., accessed December 21, 2011, at http://www.ecy.wa.gov/programs/wr/ swro/lktappshome.html.

Washington State Department of Ecology, 2010b, Report of examination to appropriate public waters permit S2-29920(A): Washington State Department of Ecology, 10 p., accessed December 21, 2011, at http://www.ecy. wa.gov/programs/wr/swro/lktappshome.html.

Washington State Department of Ecology, 2011, Water quality standards for surface waters of the State of Washington: Publication Summary, Chapter 173-201A WAC, (updated May 9, 2011), 108 p, accessed December 21, 2011, at http:// www.ecy.wa.gov/biblio/wac173201a.html. 
Wetzel, R.G., 2001, Limnology-Lake and River Ecosystems (3d ed.): San Diego, CA, Elsevier, Academic Press, 1006 p.

Wilde, F.D., ed., 2004, Cleaning of equipment for water sampling (ver. 2.0): U.S. Geological Survey Techniques of Water-Resources Investigations, book 9, chap. A3. (Also available at http://pubs.water.usgs.gov/twri9A3/.)

Wilde, F.D., 2006, Temperature (version 2): U.S. Geological Survey Techniques of Water-Resources Investigations, book 9, chap. A6, section 6.1. (Also available at http://pubs. water.usgs.gov/twri9A6/.)

Wilde, F.D., Radtke, D.B., Gibs, Jacob, and Iwatsubo, R.T., eds., 2004 (with updates through 2009), Processing of water samples (ver. 2.2): U.S. Geological Survey Techniques of Water-Resources Investigations, book 9, chap. A5. (Also available at http://pubs.water.usgs.gov/twri9A5/.)

YSI Inc., 2010, Calibration, maintenance and troubleshooting tips for YSI 6-series sondes and sensors: accessed December 21, 2011, at http://www.ysi.com/media/pdfs/YSICalibration-Maintenance-Troubleshooting-Tips-6-SeriesSondes-2-8-10.pdf.
Zaugg, S.D., Sandstrom, M.W., Smith, S.G., and Fehlberg, K.M., 1995, Methods of analysis by the U.S. Geological Survey National Water Quality Laboratory-Determination of pesticides in water by $\mathrm{C}-18$ solid-phase extraction and capillary-column gas chromatography/mass spectrometry with selected-ion monitoring: U.S. Geological Survey Open-File Report 95-181, 60 p.

Zaugg, S.D., Smith, S.G., Schroeder, M.P., Barber, L.B., and Burkhardt, M.R., 2002, Methods of analysis by the U.S. Geological Survey National Water Quality LaboratoryDetermination of wastewater compounds by polystyrenedivinylbenzene solid-phase extraction and capillary-column gas chromatography/mass spectrometry: U.S. Geological Survey Water-Resources Investigations Report 01-4186, 37 p. (Also available at http://pubs.usgs.gov/wri/ $\underline{\text { wri014186/.) }}$ 


\section{Appendix A. Field Notes and Observations Recorded during Sampling of the Nine Sites on Lake Tapps, Washington, July-December 2010}

[Map numbers are shown in figure 4. Abbreviations: m, meter; <, less than]

\begin{tabular}{|c|c|c|c|c|}
\hline \multirow{2}{*}{ Date } & \multirow{2}{*}{ Time } & \multirow{2}{*}{ Notes and observations } & \multicolumn{2}{|c|}{ Sampling depths (m) } \\
\hline & & & Eplimnion & Hypolimnion \\
\hline \multicolumn{5}{|c|}{ Deep (map No. L1) } \\
\hline July 6 & 1550 & $\begin{array}{l}\text { Niskin bottle sampler. About } 3 \text { days since last rain. Clear sky, warm, light } \\
\text { breeze, 1-2 foot waves, numerous boats and personal watercraft. Water } \\
\text { color green. }\end{array}$ & $1,2,3,4$ & $\begin{array}{l}12,13,15,17 \\
19,21,22,24\end{array}$ \\
\hline July 20 & 1200 & $\begin{array}{l}\text { Pumped sample. About } 2 \text { weeks since last rain. Cloudy, cool, light } \\
\text { breeze, water calm. No boats, personal watercraft. Water color green. }\end{array}$ & $1,3,5,6$ & $\begin{array}{l}12,13,15,17 \\
19,21,23,25\end{array}$ \\
\hline August 3 & 1100 & $\begin{array}{l}\text { Pumped sample. About } 4 \text { weeks since last rain. Cloudy, fog, cool, light } \\
\text { breeze, water calm. No boats, personal watercraft. Water color green. }\end{array}$ & $1,3,5,6$ & $\begin{array}{l}12,13,15,17 \\
19,21,23,25\end{array}$ \\
\hline August 17 & 1100 & $\begin{array}{l}\text { Pumped sample. About } 10 \text { days since last rain. Partly cloudy, filtered sun, } \\
\text { warm, light breeze, water calm. No boats, personal watercraft. }\end{array}$ & $0.5,1,2,3$ & $\begin{array}{l}14,15,16,18 \\
19,20,22,24\end{array}$ \\
\hline September 7 & 1040 & $\begin{array}{l}\text { Pumped sample. Less than } 1 / 2 \text { day since last rain. Cloudy, cool, light breeze, } \\
\text { water calm. No boats, personal watercraft. Water color green. Slight odor } \\
\text { at } 24.5 \mathrm{~m} \text {. }\end{array}$ & $1,3,5,8$ & $\begin{array}{l}13,14,17,18 \\
20,21,23,24.5\end{array}$ \\
\hline September 21 & 1020 & $\begin{array}{l}\text { Pumped sample. Less than } 1 \text { day since last rain. Partly cloudy, bright sun, } \\
\text { cool, light breeze, water calm. No boats, personal watercraft. Water color } \\
\text { green. Moderate odor and color at } 24 \mathrm{~m} \text {. }\end{array}$ & $1,3,6,9$ & $\begin{array}{l}17,18,19,20 \\
21,22,23,24\end{array}$ \\
\hline October 12 & 1030 & $\begin{array}{l}\text { Pumped sample. About } 1 \text { day since last rains (amounting to about } 1 \text { inch at } \\
\text { SeaTac Airport). Partly cloudy, filtered sun, warm, winds calm, water calm. } \\
\text { No boats, personal watercraft. Surface ripples interfering with Secchi } \\
\text { readings. Water color green. Small clusters of foam on surface. Moderate } \\
\text { odor at } 24 \mathrm{~m} \text {. }\end{array}$ & $1,3,7,10.5$ & $\begin{array}{l}16,17,18,19 \\
20,21,22,24\end{array}$ \\
\hline October 27 & 1020 & $\begin{array}{l}\text { Pumped sample. Less than } 1 \text { day since last rains (amounting to about } 2 \\
\text { inches over } 3 \text { days at SeaTac Airport). Clear sky, cool, light breeze, water } \\
\text { calm. No boats, personal watercraft. Water color green. }\end{array}$ & $1,4,8,11$ & $\begin{array}{l}16,17,18,19 \\
20,21,22,24\end{array}$ \\
\hline November 16 & 1000 & $\begin{array}{l}\text { Pumped sample. About } 1 \text { day since last rains. Cloudy, cold, windy, 1-2 foot } \\
\text { waves. No boats, personal watercraft. Surface ripples and waves made } \\
\text { Secchi difficult to read. Water color green. }\end{array}$ & $1,5,10,15$ & $\begin{array}{l}16,17,18,19 \\
20,21,22,23\end{array}$ \\
\hline December 7 & 1000 & $\begin{array}{l}\text { Pumped sample. A few hours since last rain. Cloudy, cold, winds calm, water } \\
\text { calm. Water color green. }\end{array}$ & 1 & $\begin{array}{l}2.5,4.5,7.5 \\
10.5,13.5 \\
16.5,19.5,22.5\end{array}$ \\
\hline
\end{tabular}


Appendix A. Field notes and observations recorded during sampling of the nine sites on Lake Tapps, Washington, July-December 2010.-Continued

[Map numbers are shown in figure 4. A bbreviations: m, meter; <, less than]

\begin{tabular}{|c|c|c|c|c|}
\hline \multirow{2}{*}{ Date } & \multirow{2}{*}{ Time } & \multirow{2}{*}{ Notes and observations } & \multicolumn{2}{|c|}{ Sampling depths (m) } \\
\hline & & & Eplimnion & Hypolimnion \\
\hline \multicolumn{5}{|c|}{ Allan Yorke (map No. L2) } \\
\hline July 6 & 1340 & $\begin{array}{l}\text { Niskin bottle sampler. About } 3 \text { days since last rain. Clear sky, warm, light } \\
\text { breeze, water calm. Some boats and personal watercraft. Water color } \\
\text { green. }\end{array}$ & $0.5,1$ & 4 \\
\hline July 20 & 1000 & $\begin{array}{l}\text { Pumped sample. About } 2 \text { weeks since last rain. Cloudy, fog, cool, light } \\
\text { breeze, water calm. No boats, personal watercraft. Water color green. }\end{array}$ & $0.5,1,2,3$ & 4 \\
\hline August 3 & 0950 & $\begin{array}{l}\text { Pumped sample. About } 4 \text { weeks since last rain. Cloudy, mist, fog, cool, } \\
\text { light breeze, water calm. No boats, personal watercraft. Water color } \\
\text { green. }\end{array}$ & $0.5,1,2,3$ & 4 \\
\hline August 17 & 0940 & $\begin{array}{l}\text { Pumped sample. About } 10 \text { days since last rain. Clear sky, filtered sun, } \\
\text { warm, light breeze, water calm. No boats, personal watercraft. Water } \\
\text { color green. } 23 \text { Canada geese landed near boat. }\end{array}$ & $0.5,1,2,3$ & 4 \\
\hline September 7 & 0930 & $\begin{array}{l}\text { Pumped sample. Less than } 1 / 2 \text { day since last rain. Cloudy, cool, winds } \\
\text { calm, water calm. No boats, personal watercraft. Water color yellowish } \\
\text { green; turbid (algae bloom?). }\end{array}$ & 1 & 3.5 \\
\hline September 21 & 0910 & $\begin{array}{l}\text { Pumped sample. Less than } 1 \text { day since last rain. Clear sky, bright sun, } \\
\text { cool, winds calm, water calm. No boats, personal watercraft. Water } \\
\text { color yellowish green (algae bloom?). }\end{array}$ & 1 & 4 \\
\hline October 12 & 0920 & $\begin{array}{l}\text { Pumped sample. About } 1 \text { day since last rains (amounting to about } 1 \text { inch } \\
\text { at SeaTac Airport). Partly cloudy, bright sun, cool, winds calm, water } \\
\text { calm. No boats, personal watercraft. Water color yellowish green to } \\
\text { brownish. Small clusters of foam on surface. }\end{array}$ & 1 & 3.5 \\
\hline October 26 & 0920 & $\begin{array}{l}\text { Pumped sample. Raining (moderate intensity). About } 2 \text { inches over } 3 \text { days } \\
\text { at SeaTac Airport. Cloudy, cold, light breeze, }<1 \text { foot waves. No boats, } \\
\text { personal watercraft. Water color grayish green. }\end{array}$ & 1 & 3.5 \\
\hline November 16 & 0850 & $\begin{array}{l}\text { Pumped sample. About } 1 \text { day since last rains. Cloudy, cold, windy, 1-2 } \\
\text { foot waves. No boats, personal watercraft. Water color brownish green. }\end{array}$ & 1 & 3.5 \\
\hline December 7 & 0920 & $\begin{array}{l}\text { Pumped sample. A few hours since last rain. Cloudy, cold, light breeze, } \\
\text { water calm with occasional ripples. Water color brown. }\end{array}$ & 1 & 3 \\
\hline
\end{tabular}


Appendix A. Field notes and observations recorded during sampling of the nine sites on Lake Tapps, Washington, July-December 2010.-Continued

[Map numbers are shown in figure 4. A bbreviations: m, meter; <, less than]

\begin{tabular}{|c|c|c|c|c|}
\hline \multirow{2}{*}{ Date } & \multirow{2}{*}{ Time } & \multirow{2}{*}{ Notes and observations } & \multicolumn{2}{|c|}{ Sampling depths (m) } \\
\hline & & & Eplimnion & Hypolimnion \\
\hline \multicolumn{5}{|c|}{ Northeast Arm (map No. L3) } \\
\hline July 7 & 1540 & $\begin{array}{l}\text { Niskin bottle sampler. About } 4 \text { days since last rain. Clear sky, bright sun, } \\
\text { hot, light breeze, 1-2 foot waves. Boats and personal watercraft wake } \\
\text { made Secchi difficult to read. Water color light green. }\end{array}$ & $1,2,3,4$ & 9 \\
\hline July 21 & 1500 & $\begin{array}{l}\text { Pumped sample. About } 2 \text { weeks since last rain. Clear sky, bright sun, } \\
\text { warm, light breeze, }<1 \text { foot waves. Ripples and waves made Secchi } \\
\text { difficult to read. Water color light green. }\end{array}$ & $1,3,5,6$ & 9 \\
\hline August 4 & 1450 & $\begin{array}{l}\text { Pumped sample. About } 4 \text { weeks since last rain. Clear sky, bright sun, hot, } \\
\text { light breeze, }<1 \text { foot waves. Waves made Secchi reading difficult. Water } \\
\text { color light green. }\end{array}$ & $1,3,5,6$ & 9 \\
\hline August 18 & 1420 & $\begin{array}{l}\text { Pumped sample. About } 11 \text { days since last rain. Clear sky, bright sun, } \\
\text { warm, light breeze, }<1 \text { foot waves. No boats, personal watercraft. } \\
\text { Ripples on surface during Secchi reading. Water color light green. }\end{array}$ & $0.5,1,2,3$ & 9 \\
\hline September 8 & 1410 & $\begin{array}{l}\text { Pumped sample. About } 1 / 2 \text { day since rain. Cloudy, cool, light breeze, water } \\
\text { calm. No boats, personal watercraft. }\end{array}$ & $1,3,5,8.5$ & 9 \\
\hline September 22 & 1450 & $\begin{array}{l}\text { Pumped sample. About } 2 \text { days since last rain. Cloudy, warm, light breeze, } \\
\text { water calm. No boats, personal watercraft. }\end{array}$ & 1 & 9 \\
\hline October 12 & 1400 & $\begin{array}{l}\text { Pumped sample. About } 1 \text { day since last rains (amounting to about } 1 \text { inch at } \\
\text { SeaTac Airport). Clear sky, bright sun, warm, light breeze, water calm. } \\
\text { No boats, personal watercraft. Water color green. No foam or debris on } \\
\text { surface. }\end{array}$ & 1 & 9 \\
\hline October 27 & 1220 & $\begin{array}{l}\text { Pumped sample. Less than } 1 \text { day since last rains (amounting to about } \\
2 \text { inches over } 3 \text { days at SeaTac Airport). Clear sky, bright sun, cool, } \\
\text { light breeze, }<1 \text { foot waves. No boats, personal watercraft. Water color } \\
\text { grayish green. }\end{array}$ & 1 & 9 \\
\hline November 17 & 1340 & $\begin{array}{l}\text { Pumped sample. Raining (heavy intensity). Cloudy, cold, light breeze, } \\
\text { water calm. No boats, personal watercraft. Water color green. }\end{array}$ & 1 & 8 \\
\hline December 8 & 1120 & $\begin{array}{l}\text { Pumped sample. A few hours since last rain. Partly cloudy, cold, light } \\
\text { breeze, }<1 \text { foot waves. Water color green. }\end{array}$ & 1 & 8 \\
\hline
\end{tabular}


Appendix A. Field notes and observations recorded during sampling of the nine sites on Lake Tapps, Washington, July-December 2010.-Continued

[Map numbers are shown in figure 4. A bbreviations: m, meter; <, less than]

\begin{tabular}{|c|c|c|c|c|}
\hline \multirow{2}{*}{ Date } & \multirow{2}{*}{ Time } & \multirow{2}{*}{ Notes and observations } & \multicolumn{2}{|c|}{ Sampling depths (m) } \\
\hline & & & Eplimnion & Hypolimnion \\
\hline \multicolumn{5}{|c|}{ Tapps Island (map No. L4) } \\
\hline July 8 & 0920 & $\begin{array}{l}\text { Niskin bottle sampler. About } 5 \text { days since last rain. Clear sky, bright sun, } \\
\text { cool, winds calm, water calm. }\end{array}$ & $1,3,5,6$ & $\begin{array}{l}10.5,11.5,12.5 \text {, } \\
13.5\end{array}$ \\
\hline July 21 & 1200 & $\begin{array}{l}\text { Pumped sample. About } 2 \text { weeks since last rain. Clear sky, bright sun, } \\
\text { warm, light breeze, }<1 \text { foot waves. Quiet, no boats. No defined } \\
\text { hypolimnion; steady thermocline from about } 6 \mathrm{~m} \text { to bottom. }\end{array}$ & $1,3,5,6$ & 12 \\
\hline August 4 & 1200 & $\begin{array}{l}\text { Pumped sample. About } 4 \text { weeks since last rain. Clear sky, bright sun, hot, } \\
\text { light breeze, }<1 \text { foot wave. }\end{array}$ & $1,3,5,6$ & 14 \\
\hline August 18 & 1130 & $\begin{array}{l}\text { Pumped sample. About } 11 \text { days since last rain. Cloudy, cool, light breeze, } \\
<1 \text { foot waves. Large ski boat, personal watercraft circling sample site. } \\
\text { Little shade for ideal Secchi reading. Water color grayis. }\end{array}$ & $1,2,3,4$ & 12.5 \\
\hline September 8 & 1120 & $\begin{array}{l}\text { Pumped sample. About } 1 / 2 \text { day since rain. Cloudy, cool, light breeze, }<1 \\
\text { foot waves. One boat, fishing nearby. Secchi reading not recorded. } \\
\text { Water color green. }\end{array}$ & $1,4,7,10$ & 12 \\
\hline September 22 & 1200 & $\begin{array}{l}\text { Pumped sample. About } 2 \text { days since last rain. Partly cloudy, cool, winds } \\
\text { calm, water calm. No boats, personal watercraft. Odor noticed at } 14 \text { m. }\end{array}$ & $1,3,7,10$ & 14 \\
\hline October 13 & 1140 & $\begin{array}{l}\text { Pumped sample. About } 2 \text { days since last rains (amounting to about } 1 \text { inch } \\
\text { at SeaTac Airport). Partly cloudy, cold, winds calm, water calm. No } \\
\text { boats, personal watercraft. Water color green. }\end{array}$ & $1,4,8,12.5$ & 13.5 \\
\hline October 27 & 0900 & $\begin{array}{l}\text { Pumped sample. A few hours since last rains (and about } 2 \text { inches over } \\
3 \text { days at SeaTac Airport). Partly cloudy, cool, winds calm, water calm. } \\
\text { No boats, personal watercraft. Water color green. }\end{array}$ & 1 & 13 \\
\hline November 17 & 1010 & $\begin{array}{l}\text { Pumped sample. Raining earlier in day. Cloudy, cold, windy, }<1 \text { foot } \\
\text { waves. No boats, personal watercraft. Water color green. Anchor hung } \\
\text { up on submerged snag; had to cut line. }\end{array}$ & 1 & 12.5 \\
\hline December 8 & 1200 & $\begin{array}{l}\text { Pumped sample. A few hours since last rain. Clear sky, cold, light breeze, } \\
<1 \text { foot waves. No boats, personal watercraft. Water color green. } \\
\text { Samples filtered in mobile lab back at marina. }\end{array}$ & 1 & 11.5 \\
\hline
\end{tabular}


Appendix A. Field notes and observations recorded during sampling of the nine sites on Lake Tapps, Washington, July-December 2010.-Continued

[Map numbers are shown in figure 4. A bbreviations: m, meter; <, less than]

\begin{tabular}{|c|c|c|c|c|}
\hline \multirow{2}{*}{ Date } & \multirow{2}{*}{ Time } & \multirow{2}{*}{ Notes and observations } & \multicolumn{2}{|c|}{ Sampling depths (m) } \\
\hline & & & Eplimnion & Hypolimnion \\
\hline \multicolumn{5}{|c|}{ Snagg Island (map No. L5) } \\
\hline July 7 & 1400 & $\begin{array}{l}\text { Niskin bottle sampler. About } 4 \text { days since last rain. Clear sky, bright sun, } \\
\text { light breeze, }<1 \text { foot waves. Wakes from boats and personal watercraft. } \\
\text { Water color light green. }\end{array}$ & $1,3,4,5$ & 12.5 \\
\hline July 21 & 1320 & $\begin{array}{l}\text { Pumped sample. About } 2 \text { weeks since last rain. Clear sky, bright sun, } \\
\text { warm, winds calm, waves calm. One boat pulling air tube. No shade for } \\
\text { ideal Secchi reading. Water color light green. }\end{array}$ & $1,3,4,5$ & $11,12,13$ \\
\hline August 4 & 1350 & $\begin{array}{l}\text { Pumped sample. About } 4 \text { weeks since last rain. Clear sky, bright sun, hot, } \\
\text { light breeze, water calm. Occasional boats and wakes. Water color light } \\
\text { green. }\end{array}$ & $1,3,5,6$ & $11,12,13$ \\
\hline August 18 & 1300 & $\begin{array}{l}\text { Pumped sample. About } 11 \text { days since last rain. Partly cloudy, filtered sun, } \\
\text { warm, light breeze, water calm. No boats, personal watercraft. Little } \\
\text { shade and surface ripples for ideal Secchi reading. Water color light } \\
\text { green. Tried to sample at } 14 \mathrm{~m} \text {, but large wakes caused sampler to hit } \\
\text { lake bed and draw up anaerobic, odiferous sediments. }\end{array}$ & $1,2,3,4$ & 12,13 \\
\hline September 8 & 1300 & $\begin{array}{l}\text { Pumped sample. About } 1 / 2 \text { day since rain. Cloudy, cool, light breeze, }<1 \\
\text { foot waves. One boat, fishing nearby. Ripples and reflection made for } \\
\text { non-ideal Secchi readings. Water color green. Slight odor at } 13 \mathrm{~m} \text {. }\end{array}$ & $1,3,5,8.5$ & 12,13 \\
\hline September 22 & 1350 & $\begin{array}{l}\text { Pumped sample. About } 2 \text { days since last rain. Partly cloudy, filtered sun, } \\
\text { warm, light breeze, water calm. No boats, personal watercraft. Water } \\
\text { color yellowish green. At } 13.5 \text { m, noticeable odor (organic decay?) and } \\
\text { gray color. }\end{array}$ & $1,3,6,9$ & $13,13.5$ \\
\hline October 13 & 1300 & $\begin{array}{l}\text { Pumped sample. About } 2 \text { days since last rains (amounting to about } 1 \text { inch } \\
\text { at SeaTac Airport). Clear sky, warm, light breeze, water calm. No } \\
\text { boats, personal watercraft. Water color green. At } 13 \mathrm{~m} \text {, noticeable odor } \\
\text { (organic decay?) and grayish color. }\end{array}$ & $1,4,7,10.5$ & 13 \\
\hline October 27 & 1250 & $\begin{array}{l}\text { Pumped sample. }<1 \text { day since last rains (amounting to about } 2 \text { inches over } \\
3 \text { days at SeaTac Airport). Clear sky, cool, light breeze, }<1 \text { foot waves. } \\
\text { No boats, personal watercraft. } 1 \text { gull and } 8 \text { Western Grebes. Water color } \\
\text { green. }\end{array}$ & 1 & 13 \\
\hline November 17 & 1250 & $\begin{array}{l}\text { Pumped sample. Raining (heavy intensity). Cloudy, cold, windy, }<1 \text { foot } \\
\text { waves. No boats, personal watercraft. Waves and rain ripples made } \\
\text { Secchi difficult to read. Water color green. }\end{array}$ & 1 & 12 \\
\hline December 8 & 1050 & $\begin{array}{l}\text { Pumped sample. A few hours since last rain. Clear sky, bright sun, cold, } \\
\text { light breeze, }<1 \text { foot waves. No boats, personal watercraft. Water color } \\
\text { green. }\end{array}$ & 1 & 11.5 \\
\hline
\end{tabular}


Appendix A. Field notes and observations recorded during sampling of the nine sites on Lake Tapps, Washington, July-December 2010.-Continued

[Map numbers are shown in figure 4. A bbreviations: m, meter; <, less than]

\begin{tabular}{|c|c|c|c|c|}
\hline \multirow{2}{*}{ Date } & \multirow{2}{*}{ Time } & \multirow{2}{*}{ Notes and observations } & \multicolumn{2}{|c|}{ Sampling depths (m) } \\
\hline & & & Eplimnion & Hypolimnion \\
\hline \multicolumn{5}{|c|}{ Lake Inlet (map No. L6) } \\
\hline July 8 & 1300 & $\begin{array}{l}\text { Niskin bottle sampler. About } 5 \text { days since last rain. Clear sky, bright sun, } \\
\text { hot. Wakes from boats and personal watercraft made Secchi difficult to } \\
\text { read. }\end{array}$ & 1 & $4.5,5$ \\
\hline July 20 & 1500 & $\begin{array}{l}\text { Pumped sample. About } 2 \text { weeks since last rain. Partly cloudy, filtered sun, } \\
\text { warm, winds calm, waves calm. Water color light green. }\end{array}$ & $1,2,3,4$ & $4.5,5$ \\
\hline August 3 & 1420 & $\begin{array}{l}\text { Pumped sample. About } 4 \text { weeks since last rain. Mostly clear sky, bright } \\
\text { sun, hot, light breeze, water calm. Few boats. Water color light green. }\end{array}$ & $1,2,3,4$ & 5 \\
\hline August 17 & 1420 & $\begin{array}{l}\text { Pumped sample. About } 10 \text { days since last rain. Clear sky, bright sun, very } \\
\text { warm, light breeze, }<1 \text { foot waves. Occasional boats causing } 1-2 \text { foot } \\
\text { wakes. Water color light green. }\end{array}$ & 1 & 5 \\
\hline September 7 & 1430 & $\begin{array}{l}\text { Pumped sample. About } 1 / 2 \text { day since rain. Cloudy, warm, light breeze, } \\
\text { water calm. No boats, personal watercraft. Some ripples during Secchi } \\
\text { reading. Water slightly turbid (algae?). }\end{array}$ & 1 & 4.5 \\
\hline September 21 & 1320 & $\begin{array}{l}\text { Pumped sample. About } 1 \text { day since last rain. Partly cloudy, bright sun, } \\
\text { cool, light breeze, }<1 \text { foot waves. No boats, personal watercraft. Water } \\
\text { color green. }\end{array}$ & 1 & 4 \\
\hline October 12 & 1330 & $\begin{array}{l}\text { Pumped sample. About } 1 \text { day since last rains (amounting to about } 1 \text { inch } \\
\text { at SeaTac Airport). Clear sky, bright sun, warm, light breeze, }<1 \text { foot } \\
\text { waves. No boats, personal watercraft. Water color green. }\end{array}$ & 1 & 4.5 \\
\hline October 26 & 1030 & $\begin{array}{l}\text { Pumped sample. Raining (moderate intensity). About } 2 \text { inches over } 3 \text { days } \\
\text { at SeaTac Airport. Cloudy, cold, windy, }<1 \text { foot waves. Western Grebes } \\
\text { nearby. No boats, personal watercraft. Water color grayish green. }\end{array}$ & 1 & 4.5 \\
\hline November 16 & 1240 & $\begin{array}{l}\text { Pumped sample. About } 1 \text { day since last rains. Cloudy, cold, windy, }<1 \text { foot } \\
\text { waves. No boats, personal watercraft. Surface ripples and wind made } \\
\text { Secchi difficult to read. Water color green. }\end{array}$ & 1 & 4 \\
\hline December 7 & 1220 & $\begin{array}{l}\text { Pumped sample. A few hours since last rain. Cloudy, cold, light breeze, }<1 \\
\text { foot waves. Water color green. }\end{array}$ & 1 & 3.5 \\
\hline
\end{tabular}


Appendix A. Field notes and observations recorded during sampling of the nine sites on Lake Tapps, Washington, July-December 2010.-Continued

[Map numbers are shown in figure 4. A bbreviations: m, meter; <, less than]

\begin{tabular}{|c|c|c|c|c|}
\hline \multirow{2}{*}{ Date } & \multirow{2}{*}{ Time } & \multirow{2}{*}{ Notes and observations } & \multicolumn{2}{|c|}{ Sampling depths (m) } \\
\hline & & & Eplimnion & Hypolimnion \\
\hline \multicolumn{5}{|c|}{ Southeast Arm (map No. L7) } \\
\hline July 20 & 1630 & Pumped sample. About 2 weeks since last rain. Partly cloudy, warm. & 1 & 3 \\
\hline August 3 & 1320 & $\begin{array}{l}\text { Pumped sample. About } 4 \text { weeks since last rain. Cloudy, filtered sun, warm, } \\
\text { light breeze, water calm. No boats. Water color light green. }\end{array}$ & 1 & 3 \\
\hline August 17 & 1330 & $\begin{array}{l}\text { Pumped sample. About } 10 \text { days since last rain. Clear sky, some light } \\
\text { clouds, bright sun, warm, winds calm, water calm. Occasional boats and } \\
\text { wakes. No shade for ideal Secchi reading. Rooted aquatic macrophytes } \\
\text { (milfoil?). Water color light green. }\end{array}$ & 1 & 3 \\
\hline September 7 & 1340 & $\begin{array}{l}\text { Pumped sample. About 1/2 day since rain. Cloudy, warm, winds calm, } \\
\text { water calm. Water color green and slightly turbid (algae?). }\end{array}$ & 1 & 2.5 \\
\hline September 21 & 1250 & $\begin{array}{l}\text { Pumped sample. About } 1 \text { day since last rain. Partly cloudy, light breeze, } \\
\text { water calm. No boats, personal watercraft. Water color yellowish green } \\
\text { and turbid. }\end{array}$ & 1 & 2.5 \\
\hline October 12 & 1250 & $\begin{array}{l}\text { Pumped sample. About } 1 \text { day since last rains (amounting to about } 1 \text { inch at } \\
\text { SeaTac Airport). Clear sky, bright sun, warm, winds calm, water calm. } \\
\text { No boats, personal watercraft. Water color green and turbid. Clusters of } \\
\text { foam on surface. }\end{array}$ & 1 & 2.5 \\
\hline October 26 & 1110 & $\begin{array}{l}\text { Pumped sample. Raining (moderate intensity). About } 2 \text { inches over } 3 \text { days } \\
\text { at SeaTac Airport. Cloudy, fog, cold, windy, }<1 \text { foot waves. No boats, } \\
\text { personal watercraft. Water color grayish to brownish green. }\end{array}$ & 1 & 2 \\
\hline November 16 & 1210 & $\begin{array}{l}\text { Pumped sample. About } 1 \text { day since last rains. Cloudy, cold, windy, } \\
\text { 1-2 foot waves. No boats, personal watercraft. }\end{array}$ & 1 & 2 \\
\hline December 7 & 1140 & $\begin{array}{l}\text { Pumped sample. A few hours since last rain. Cloudy, cold, light breeze, } \\
<1 \text { foot waves. Water color brown. }\end{array}$ & 1 & 1.5 \\
\hline
\end{tabular}


Appendix A. Field notes and observations recorded during sampling of the nine sites on Lake Tapps, Washington, July-December 2010.-Continued

[Map numbers are shown in figure 4. A bbreviations: m, meter; <, less than]

\begin{tabular}{|c|c|c|c|c|}
\hline \multirow{2}{*}{ Date } & \multirow{2}{*}{ Time } & \multirow{2}{*}{ Notes and observations } & \multicolumn{2}{|c|}{ Sampling depths (m) } \\
\hline & & & Eplimnion & Hypolimnion \\
\hline \multicolumn{5}{|c|}{ Lake Outflow (map No. L8) } \\
\hline July 21 & 0940 & $\begin{array}{l}\text { Pumped sample. About } 2 \text { weeks since last rain. Cloudy, fog, cool, light } \\
\text { breeze, waves calm. No boats. }\end{array}$ & $1,3,5,6$ & 8 \\
\hline August 4 & 1010 & $\begin{array}{l}\text { Pumped sample. About } 4 \text { weeks since last rain. Partly cloudy, filtered } \\
\text { sun, cool, light breeze, water calm. No boats. Water color light green. }\end{array}$ & $1,3,4,5$ & 9.5 \\
\hline August 18 & 0930 & $\begin{array}{l}\text { Pumped sample. About } 11 \text { days since last rain. Cloudy, filtered sun, } \\
\text { cool, light breeze, }<1 \text { foot waves. No boats, personal watercraft. } \\
\text { Water color light green. }\end{array}$ & $1,2,3,4$ & 8 \\
\hline September 8 & 0930 & $\begin{array}{l}\text { Pumped sample. Raining (medium intensity); intermittent rain began } \\
\text { about 0100. Cloudy, cool, light breeze, water calm. Water color } \\
\text { green. Ripples and reflection made for non-ideal Secchi readings. No } \\
\text { boats, personal watercraft. }\end{array}$ & $1,3,5,8.5$ & 9 \\
\hline September 22 & 0940 & $\begin{array}{l}\text { Pumped sample. About } 2 \text { days since last rain. Partly cloudy, cool, light } \\
\text { breeze, water calm. Water color green. }\end{array}$ & $1,3,6,8$ & 9 \\
\hline October 13 & 0950 & $\begin{array}{l}\text { Pumped sample. About } 2 \text { days since last rains (amounting to about } 1 \\
\text { inch at SeaTac Airport). Clear sky, fog, cold, winds calm, water calm. } \\
\text { No boats, personal watercraft. Water color green. }\end{array}$ & 1 & 8.5 \\
\hline October 26 & 1340 & $\begin{array}{l}\text { Pumped sample. Raining (moderate intensity). About } 2 \text { inches over } \\
3 \text { days at SeaTac Airport. Cloudy, cold, light breeze, water calm but } \\
\text { very windy out in main lake. No boats, personal watercraft. Water } \\
\text { color grayish green. }\end{array}$ & 1 & 9 \\
\hline November 17 & 1120 & $\begin{array}{l}\text { Pumped sample. Raining a few hours earlier in the day. Cloudy, cold, } \\
\text { light breeze, water calm. No boats, personal watercraft. Water color } \\
\text { green. Held boat in position with engine; anchor lost at previous site. }\end{array}$ & 1 & 7.5 \\
\hline December 8 & 0830 & $\begin{array}{l}\text { Pumped sample. Raining (light intensity). Cloudy, cold, winds calm, } \\
\text { water calm. No boats, personal watercraft. Water color green. } \\
\text { Samples filtered in mobile lab back at marina. }\end{array}$ & 1 & 7 \\
\hline
\end{tabular}


Appendix A. Field notes and observations recorded during sampling of the nine sites on Lake Tapps, Washington, July-December 2010.-Continued

[Map numbers are shown in figure 4. A bbreviations: m, meter; <, less than]

\begin{tabular}{|c|c|c|c|c|}
\hline \multirow{2}{*}{ Date } & \multirow{2}{*}{ Time } & \multirow{2}{*}{ Notes and observations } & \multicolumn{2}{|c|}{ Sampling depths (m) } \\
\hline & & & Eplimnion & Hypolimnion \\
\hline \multicolumn{5}{|c|}{ Dike 2B (map No. L9) } \\
\hline July 21 & 1050 & $\begin{array}{l}\text { Pumped sample. About } 2 \text { weeks since last rain. Partly cloudy, filtered sun, } \\
\text { cool, light breeze, waves calm. One boat, fishing. Can see Secchi at } \\
\text { depth ( } 3.2 \mathrm{~m}) \text {. Touched lake bed when setting sampler at } 3.5 \mathrm{~m} \text {. Water } \\
\text { color light green. }\end{array}$ & 1 & 2.5 \\
\hline August 4 & 1110 & $\begin{array}{l}\text { Pumped sample. About } 4 \text { weeks since last rain. Partly cloudy, filtered sun, } \\
\text { warm, light breeze, water calm. No boats. Secchi obscured by rooted } \\
\text { vegetation (milfoil?). Water color light green. }\end{array}$ & 1 & 4 \\
\hline August 18 & 1020 & $\begin{array}{l}\text { Pumped sample. About } 11 \text { days since last rain. Cloudy, filtered sun, cool, } \\
\text { winds calm, water calm. No boats, personal watercraft. } 2 \text { mallards near } \\
\text { boat. Can see Secchi at depth }(5.4 \mathrm{~m}) \text {. Water color light green. }\end{array}$ & 1 & 4 \\
\hline September 8 & 1020 & $\begin{array}{l}\text { Pumped sample. Raining (medium intensity); intermittent rain began } \\
\text { about 0100. Cloudy, cool, light breeze, water calm. Water color green. } \\
\text { Secchi visible at depth. No boats, personal watercraft. }\end{array}$ & 1 & 4 \\
\hline September 22 & 1050 & $\begin{array}{l}\text { Pumped sample. About } 2 \text { days since last rain. Partly cloudy, bright sun, } \\
\text { cool, water calm. No boats, personal watercraft. Secchi visible at depth. }\end{array}$ & 1 & 4.5 \\
\hline October 13 & 1040 & $\begin{array}{l}\text { Pumped sample. About } 2 \text { days since last rains (amounting to about } 1 \text { inch } \\
\text { at SeaTac Airport). Clear sky, fog, cold, winds calm, water calm. One } \\
\text { boat, fishing. A few mallards. Secchi visible at depth (about } 5 \mathrm{~m} \text { ). Water } \\
\text { color green. }\end{array}$ & 1 & 4 \\
\hline October 26 & 1250 & $\begin{array}{l}\text { Pumped sample. Raining (light intensity). About } 2 \text { inches over } 3 \text { days at } \\
\text { SeaTac Airport. Cloudy, cold, windy, }<1 \text { foot waves. No boats, personal } \\
\text { watercraft. Secchi visible at depth. Water color grayish green. Wind } \\
\text { pushing boat off sampling mark for hypolimnion sample. }\end{array}$ & 1 & 2 \\
\hline November 17 & 0930 & $\begin{array}{l}\text { Pumped sample. Raining (light intensity). Cloudy, cold, windy, }<1 \text { foot } \\
\text { waves. Water color green. }\end{array}$ & 1 & 2.5 \\
\hline December 8 & 0920 & $\begin{array}{l}\text { Pumped sample. Raining (medium intensity). Cloudy, cold, light breeze, } \\
\text { water calm. No boats, personal watercraft. Rain and ripples made } \\
\text { Secchi difficult to read. Water color green. Samples filtered in mobile } \\
\text { lab back at marina. }\end{array}$ & 1 & 2.5 \\
\hline
\end{tabular}




\section{Appendix B. Parameter Codes, Analytical Methods, and Reporting Levels for Analytes in National Water Quality Laboratory Schedule 1865 (Nutrients) and Schedule 1637 (Chlorophyll a and Pheophytin a)}

[CAS Registry Number ${ }^{\circledR}$ is a registered trademark of the American Chemical Society. CAS recommends the verification of the CAS Registry Numbers through CAS Client Services ${ }^{\mathrm{SM}}$. A bbreviations: NWIS, National Water Information System; CAS, Chemical Abstract Services; ltmdl, long-term method detection level; mdl, method detection level; $\mathrm{mg} / \mathrm{L}$, milligram per liter; $\mu \mathrm{g} / \mathrm{L}$, microgram per liter; mrl, minimum reporting level; $\mathrm{NH}_{3}$, ammonia; $\mathrm{NO}_{2}$, nitrite; $\mathrm{NO}_{3}$, nitrate]

Schedule 1865, Nutrients

\begin{tabular}{lccccc}
\hline \multicolumn{1}{c}{ Parameter name } & $\begin{array}{c}\text { NWIS } \\
\text { parameter } \\
\text { code }\end{array}$ & $\begin{array}{c}\text { CAS } \\
\text { Registry } \\
\text { Number }\end{array}$ & $\begin{array}{c}\text { Analytical } \\
\text { method }\end{array}$ & $\begin{array}{c}\text { Reporting level } \\
\text { (mg/L) }\end{array}$ & $\begin{array}{c}\text { Reporting } \\
\text { level type }\end{array}$ \\
\hline Nitrogen, ammonia, filtered & 00608 & $7664-41-7$ & I-2525-89 & 0.010 & ltmdl \\
Nitrogen, nitrite, filtered & 00613 & $14797-65-0$ & I-2540-90 & .001 & mdl \\
Nitrogen, nitrite plus nitrate, filtered & 00631 & - & I-2546091 & .008 & ltmdl \\
Phosphorus, filtered & 00666 & $7723-14-0$ & EPA 365.1 & .003 & ltmdl \\
Phosphorus, unfiltered & 00665 & $7723-14-0$ & EPA 365.1 & .004 & ltmdl \\
Phosphorus, phosphate, ortho, filtered & 00671 & $14265-44-2$ & I-2601-90 & .004 & ltmdl \\
Total nitrogen (NH3+NO2+NO3+Organic), filtered & 62854 & $17778-88-0$ & I-2650-03 & .05 & ltmdl \\
Total nitrogen (NH3+NO2+NO3+Organic), unfiltered & 62855 & $17778-88-0$ & I-4650-03 & .05 & ltmdl \\
\hline
\end{tabular}

Schedule 1637, Chlorophyll

\begin{tabular}{lcccc}
\hline \multicolumn{1}{c}{ Parameter name } & $\begin{array}{c}\text { NWIS } \\
\text { Parameter } \\
\text { code }\end{array}$ & $\begin{array}{c}\text { CAS } \\
\text { Registry }_{\text {Number }^{\circledR}}\end{array}$ & $\begin{array}{c}\text { Reporting level } \\
(\boldsymbol{\mu g} / \mathbf{L})\end{array}$ & $\begin{array}{c}\text { Reporting } \\
\text { level type }\end{array}$ \\
\hline $\begin{array}{l}\text { Chlorophyll } a \text {, phytoplankton } \\
\text { Pheophytin } a \text {, phytoplankton }\end{array}$ & 70953 & $479-61-8$ & 0.1 & $\mathrm{mrl}$ \\
\hline
\end{tabular}



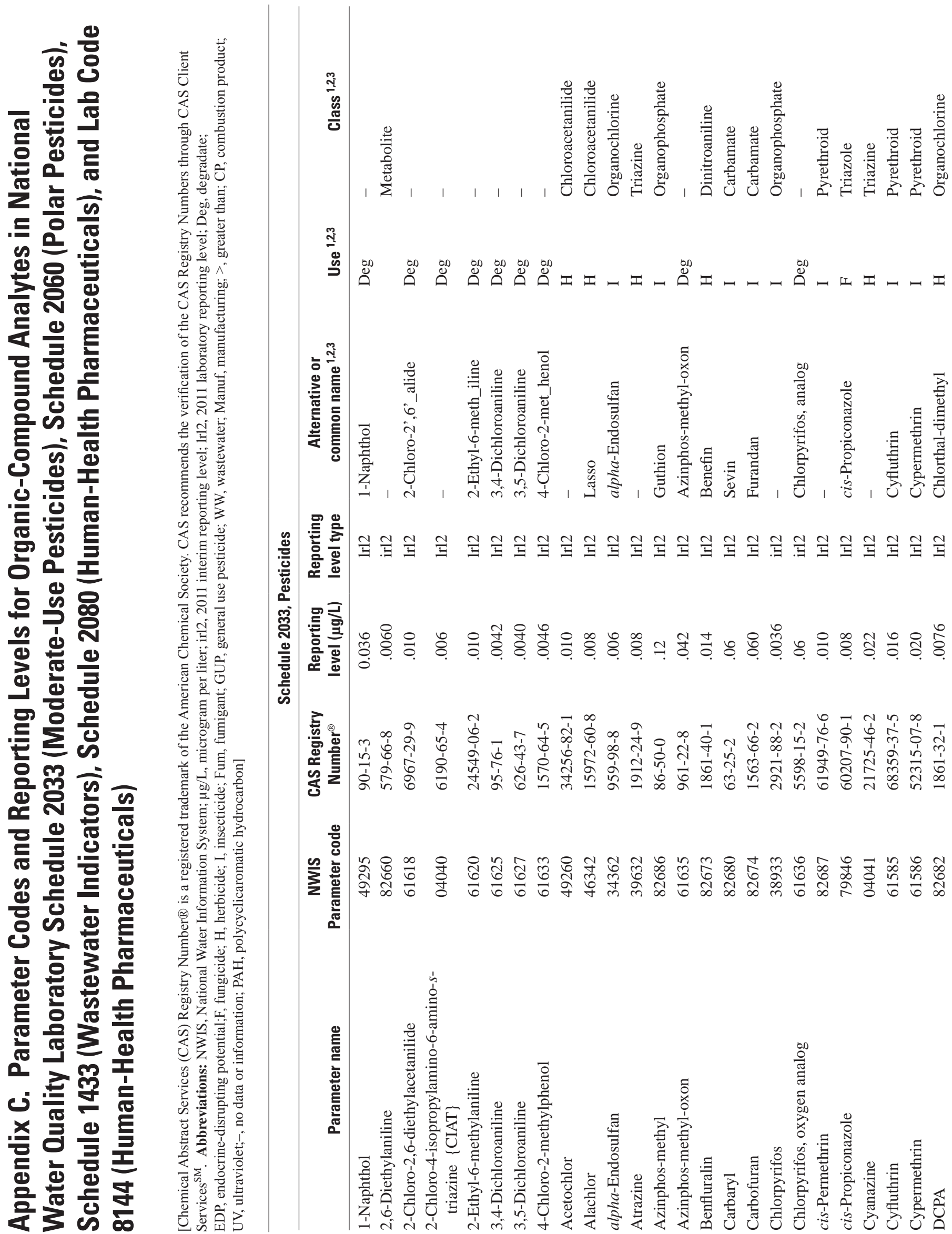


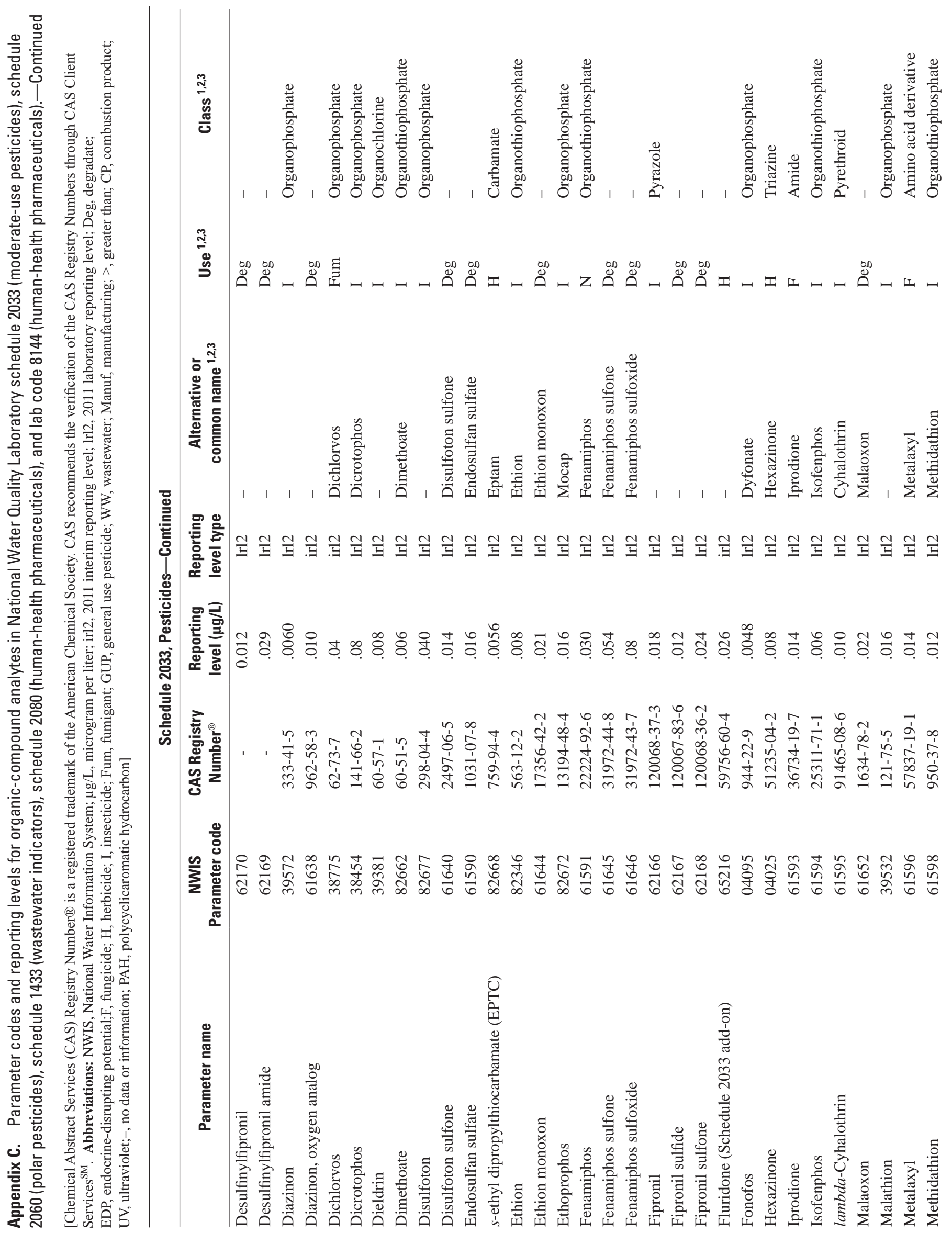




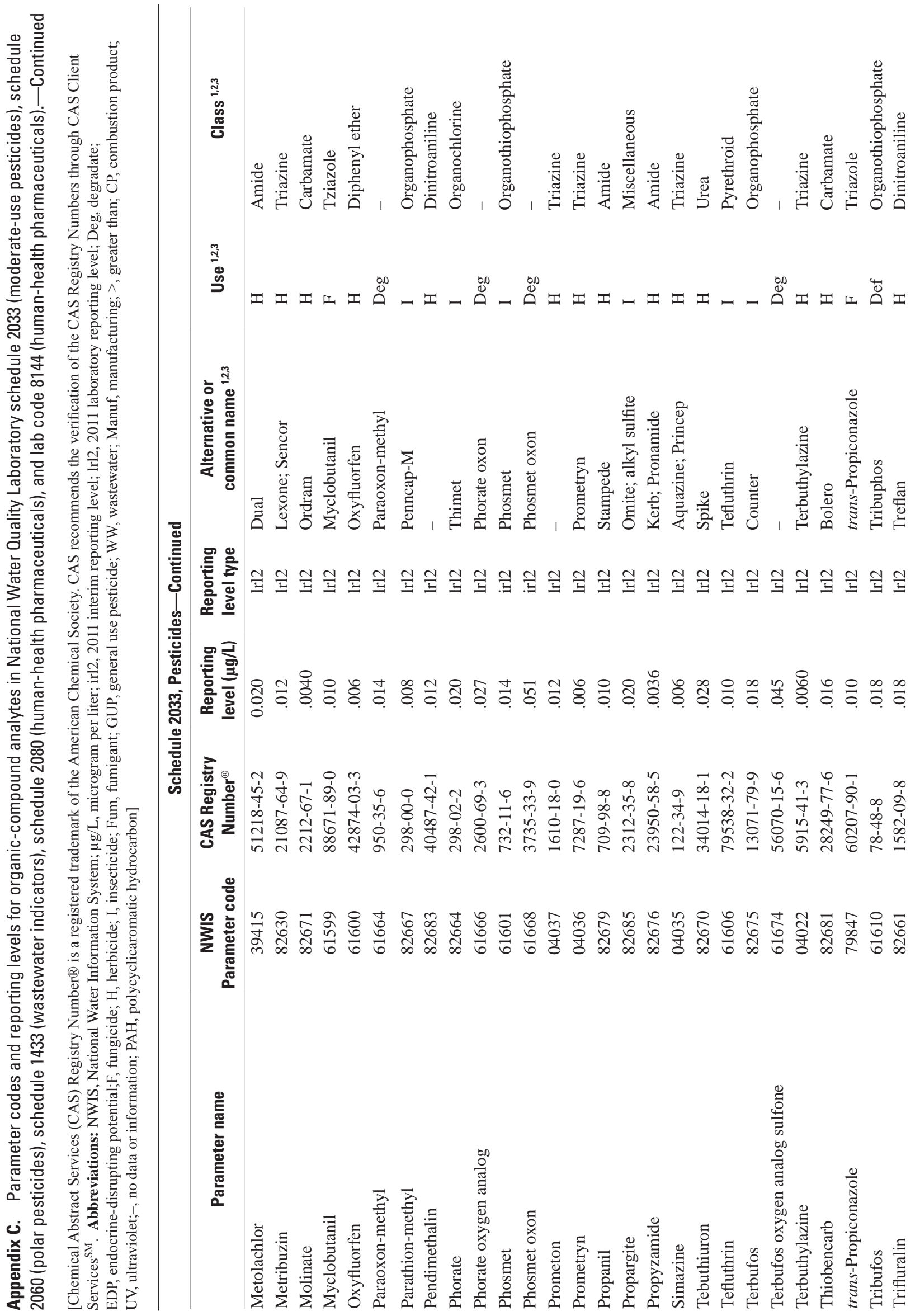




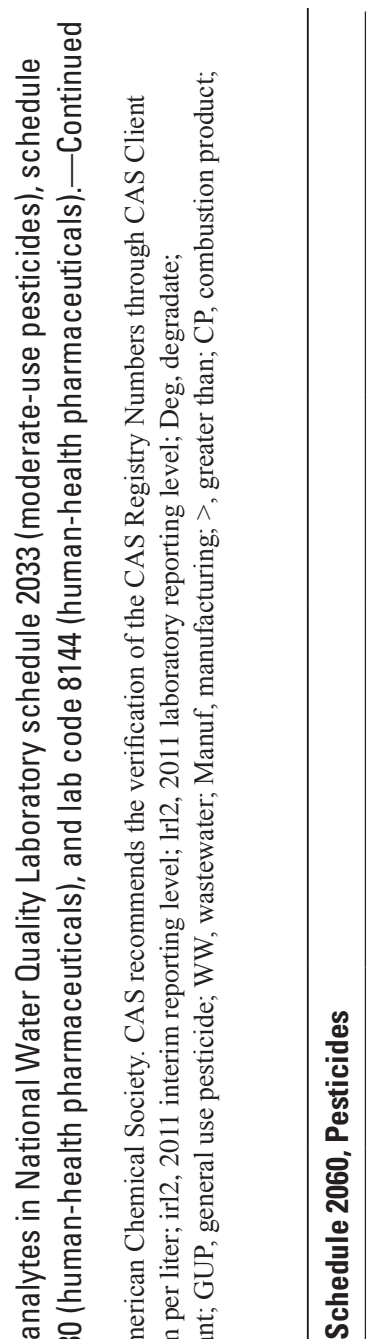

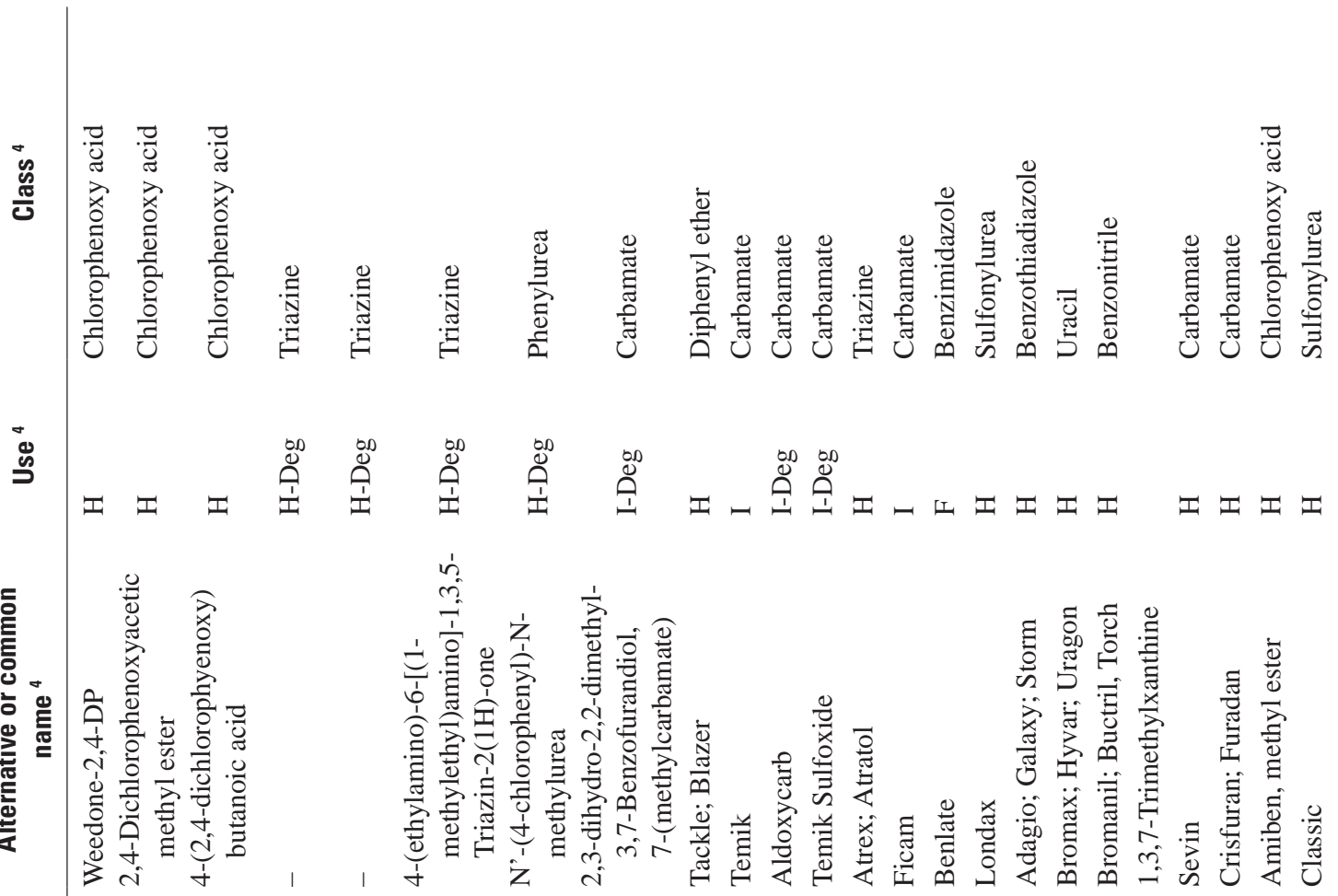

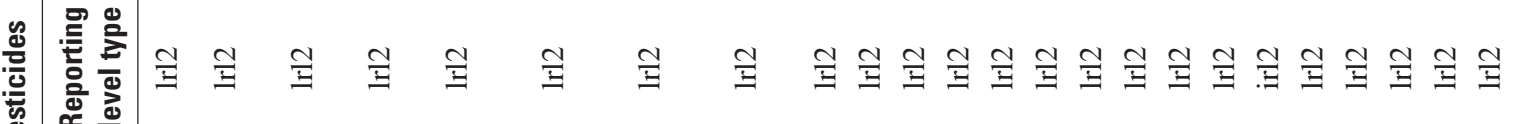

를롤 $\stackrel{0}{\square}$

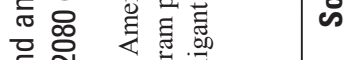

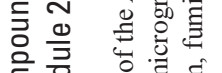

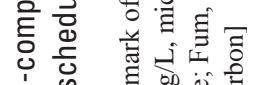

í

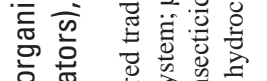

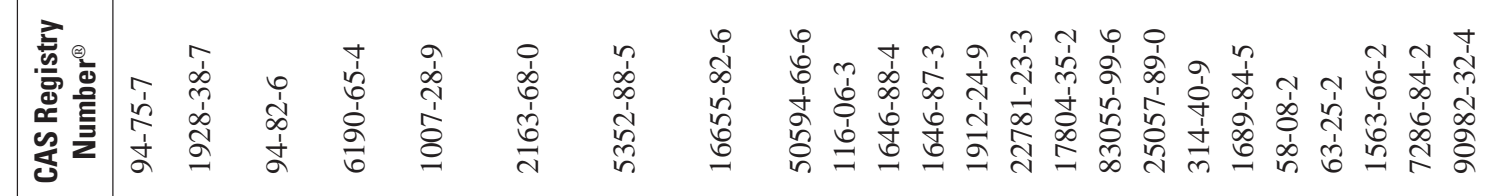

흔

$\frac{\infty}{9}$.

万人

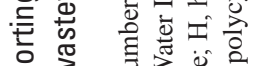

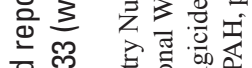

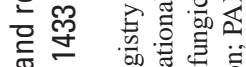

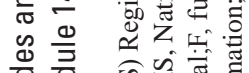

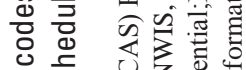

힝

屯

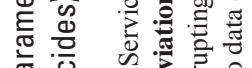

\%

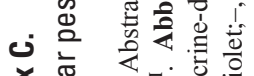

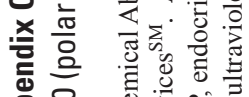

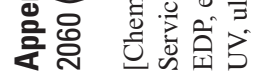
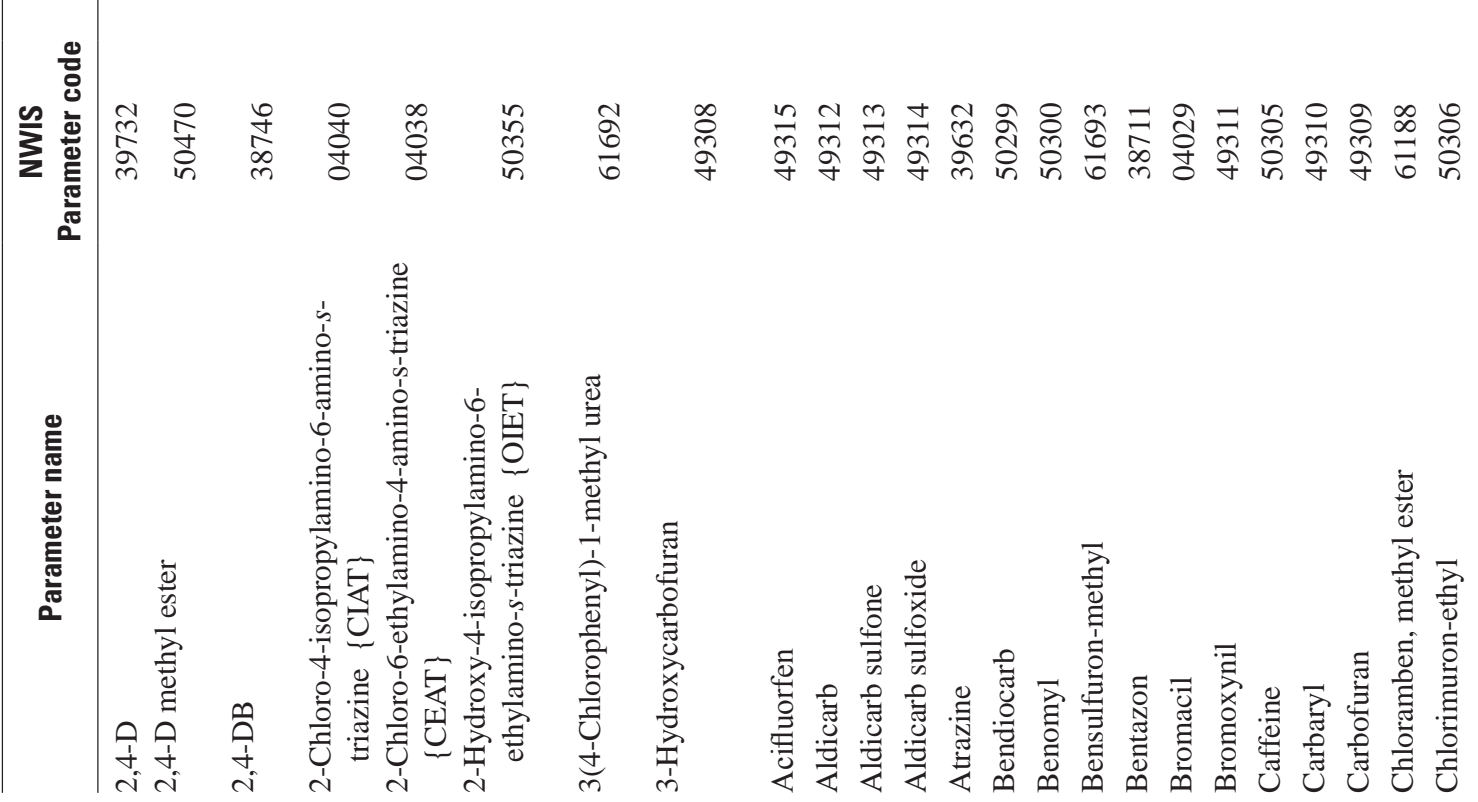


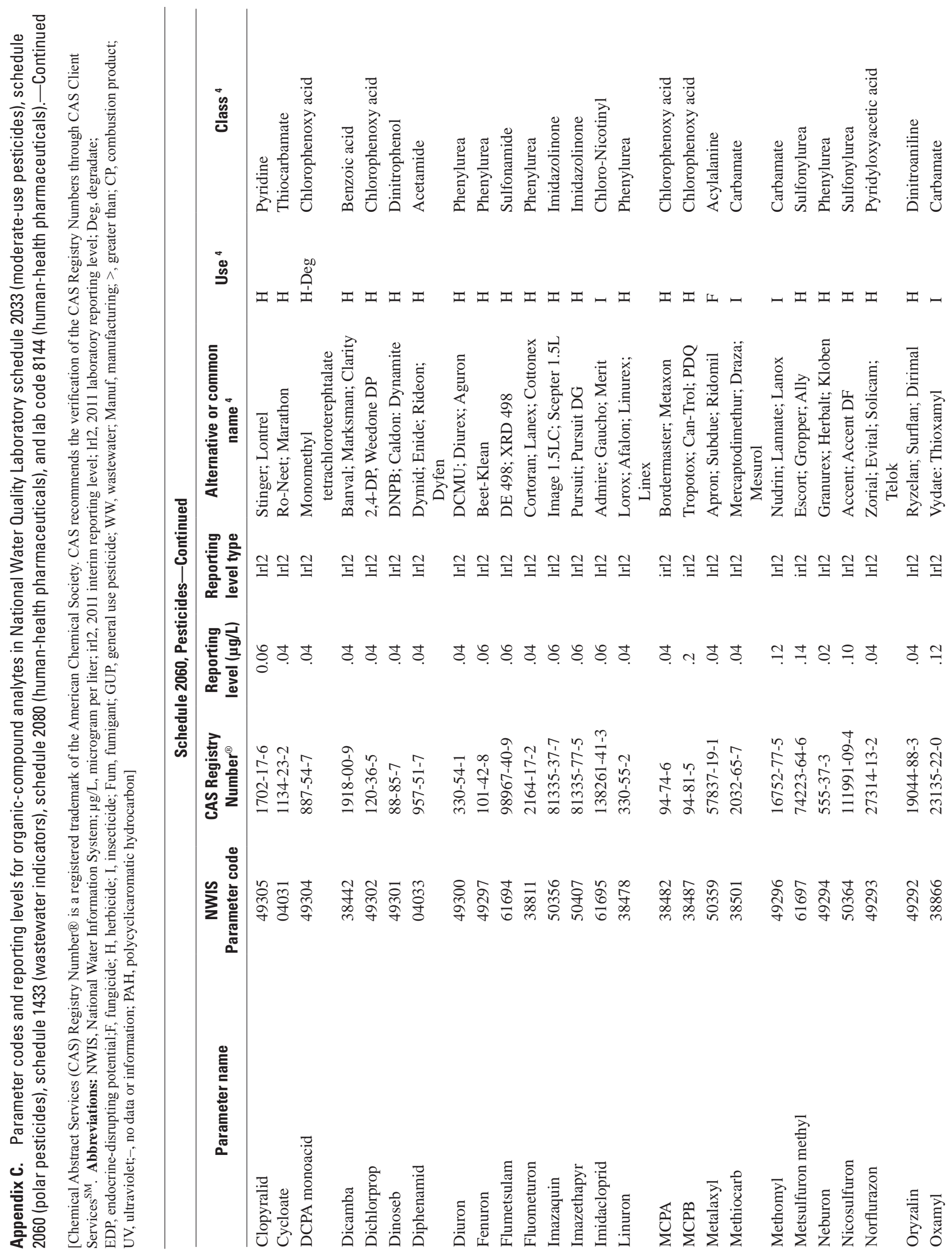




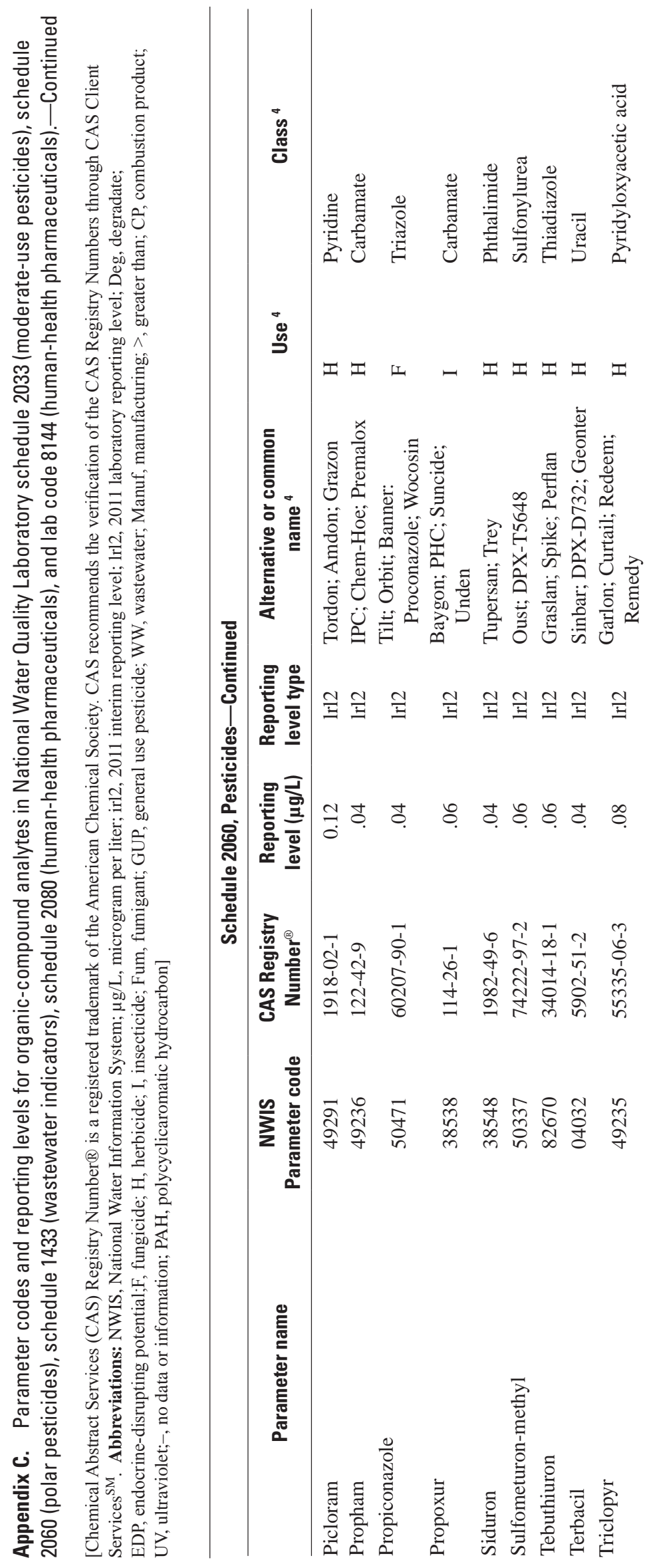




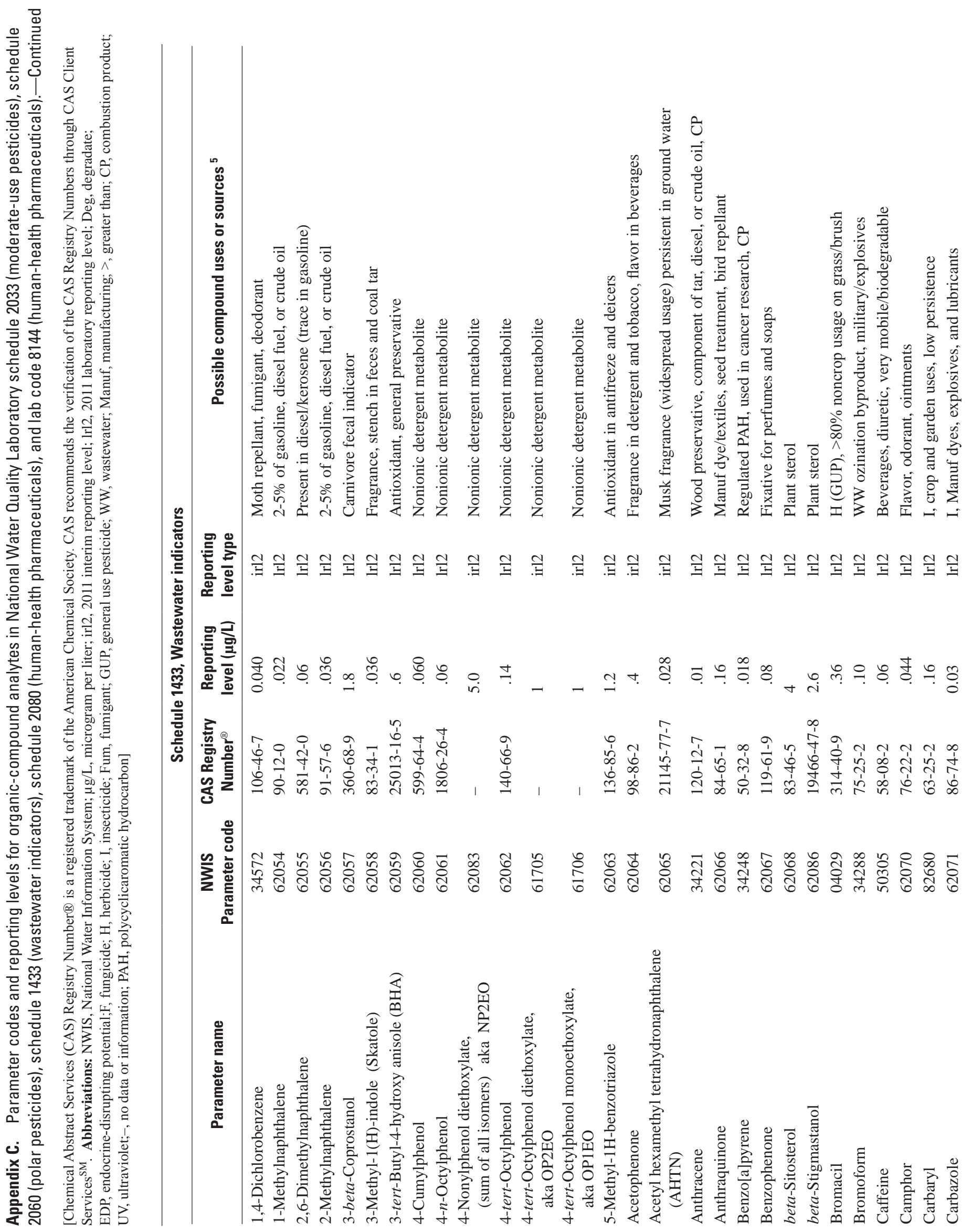



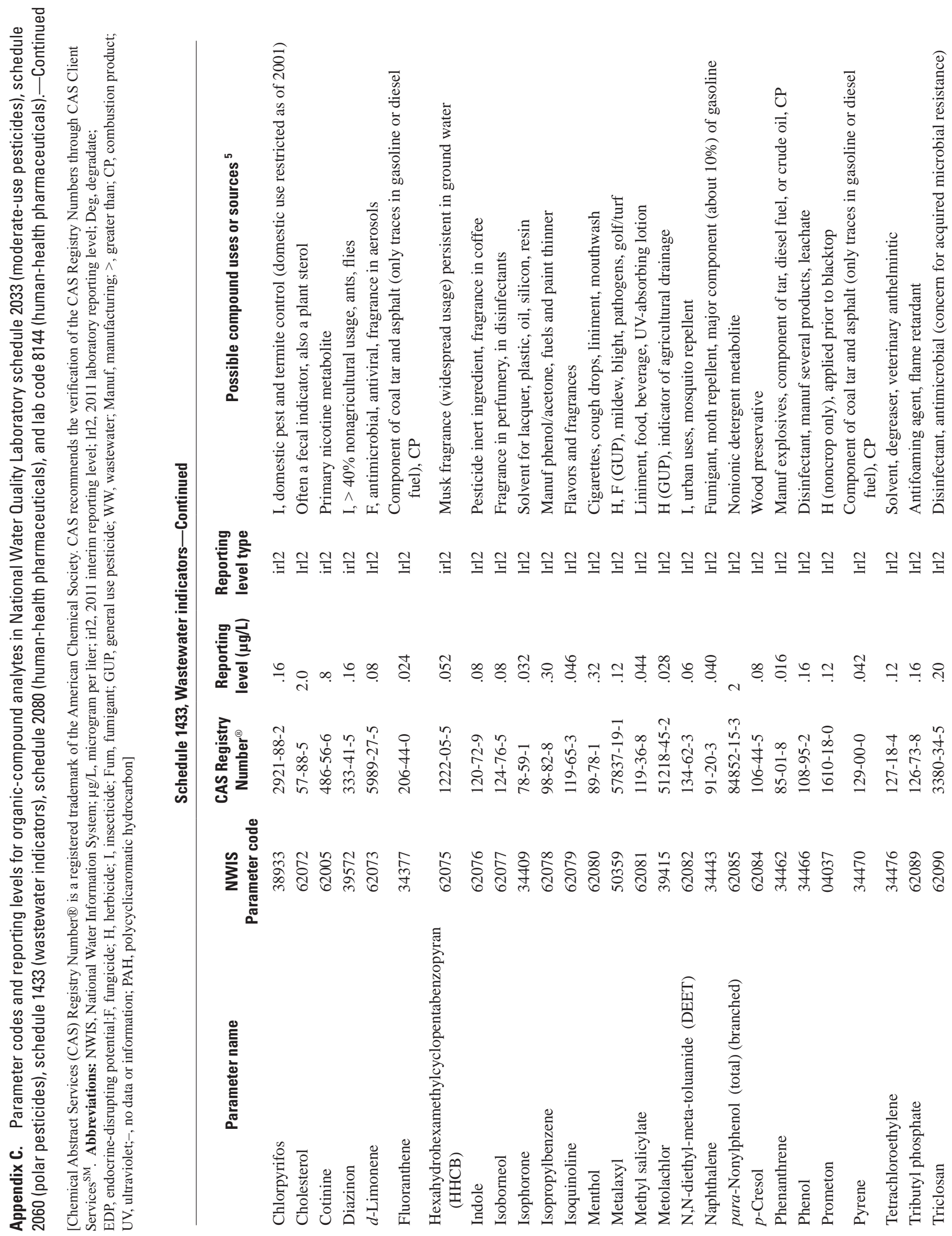

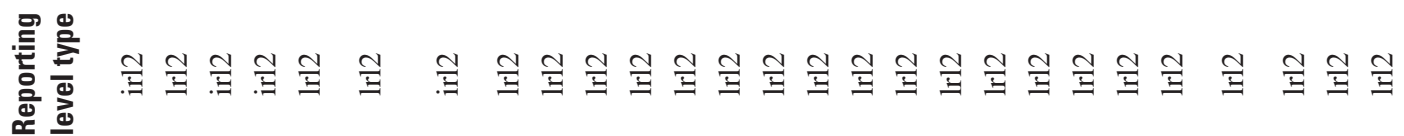
을 $\because$ 우

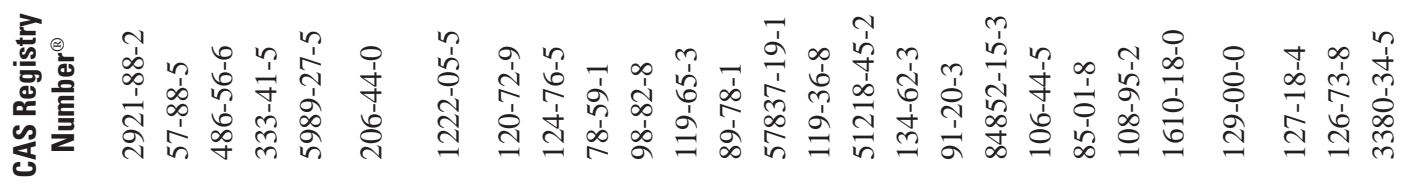

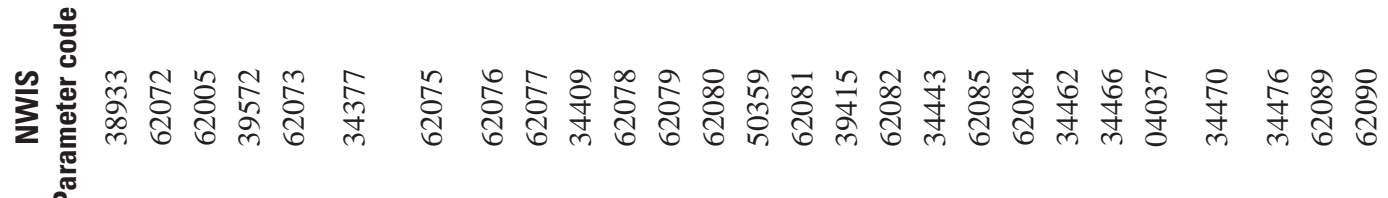

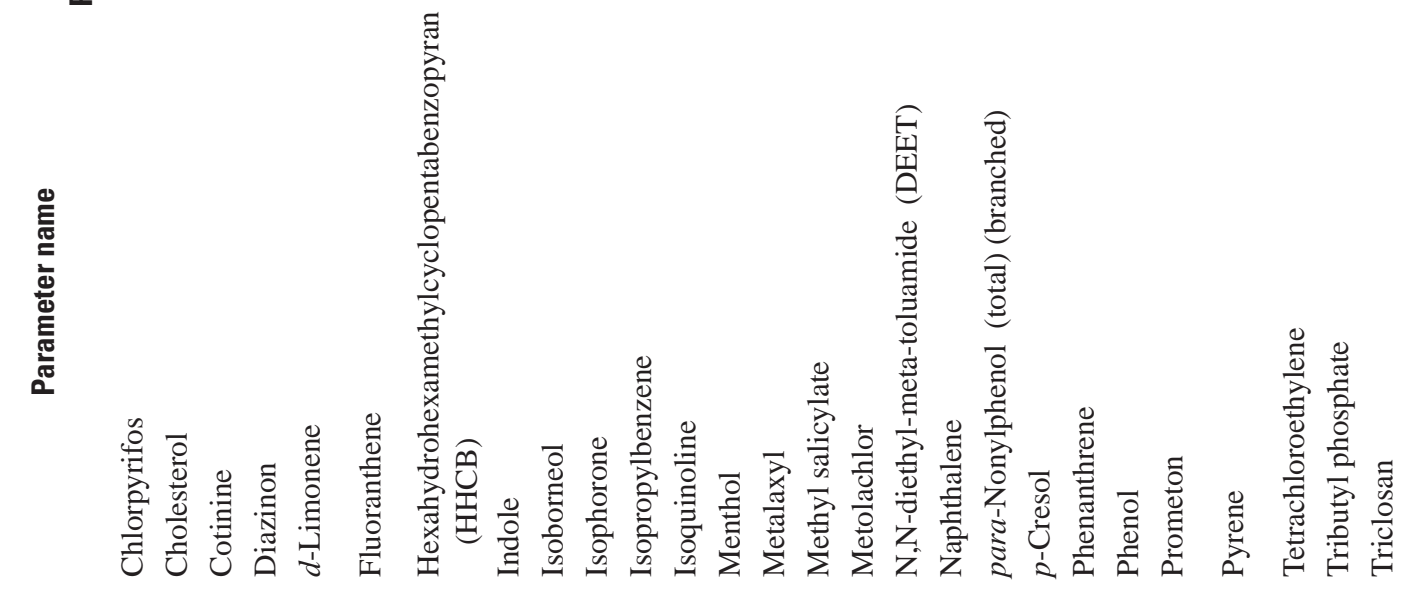




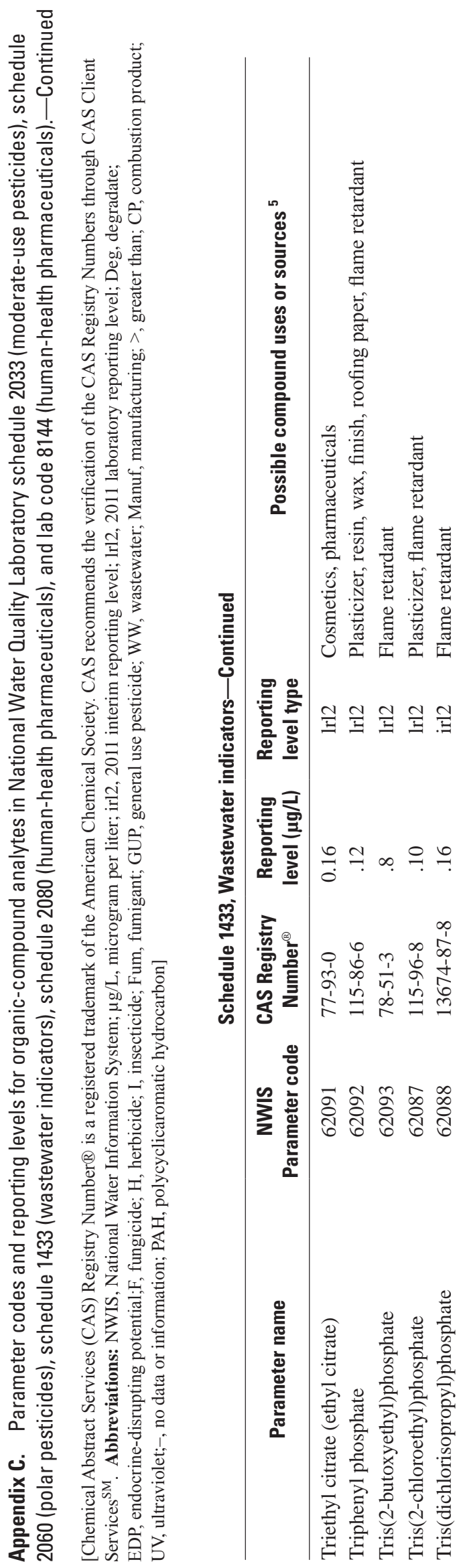




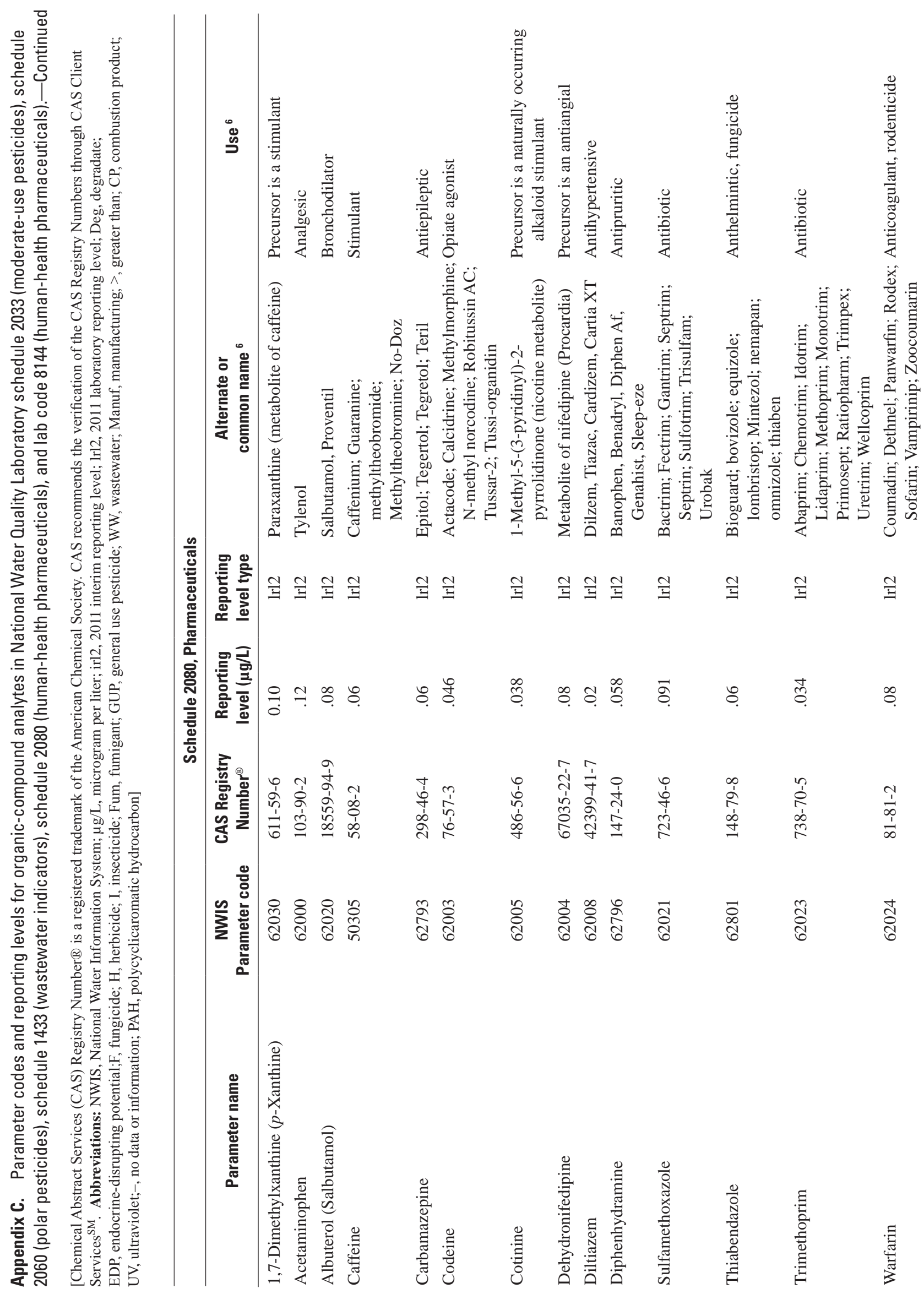




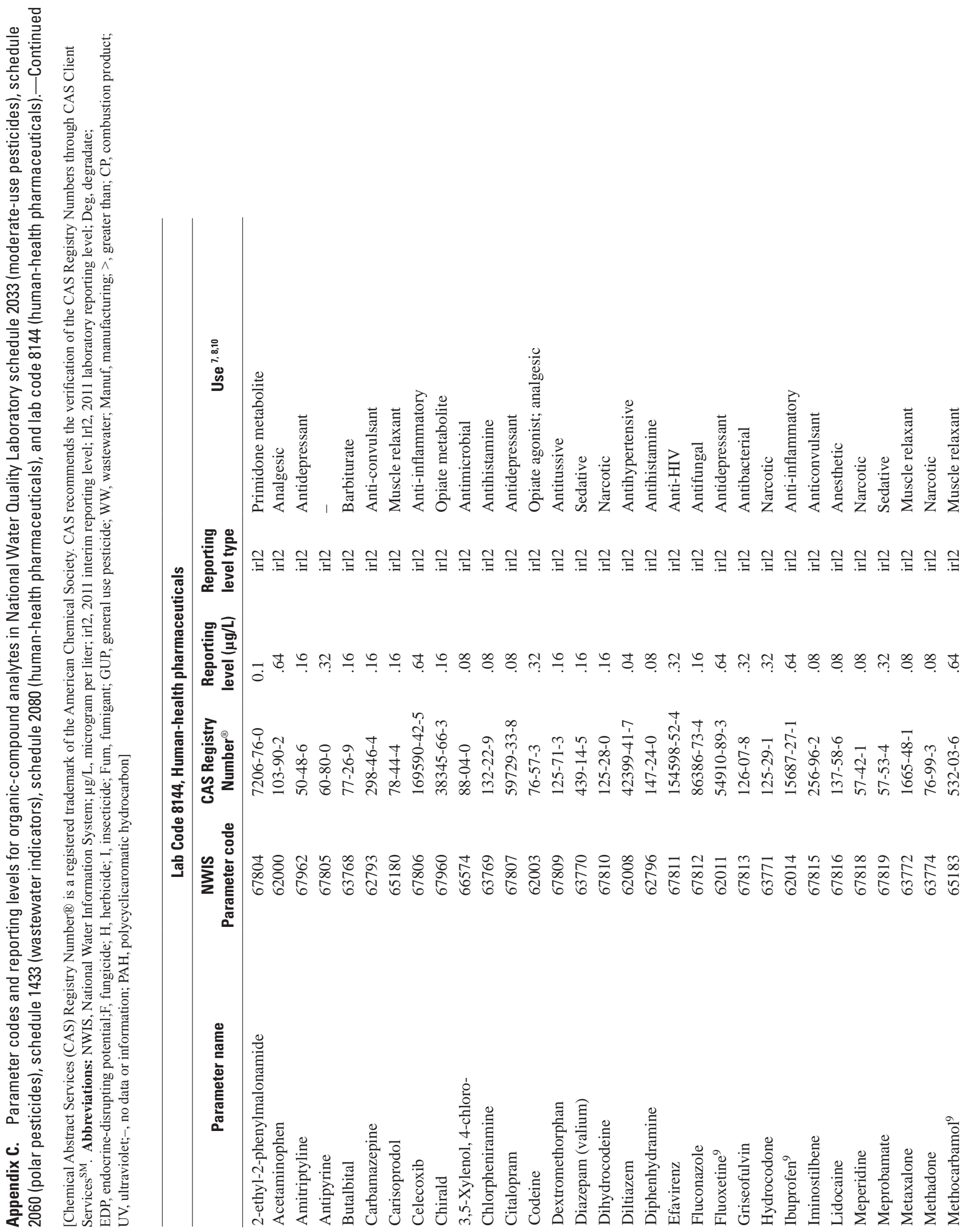



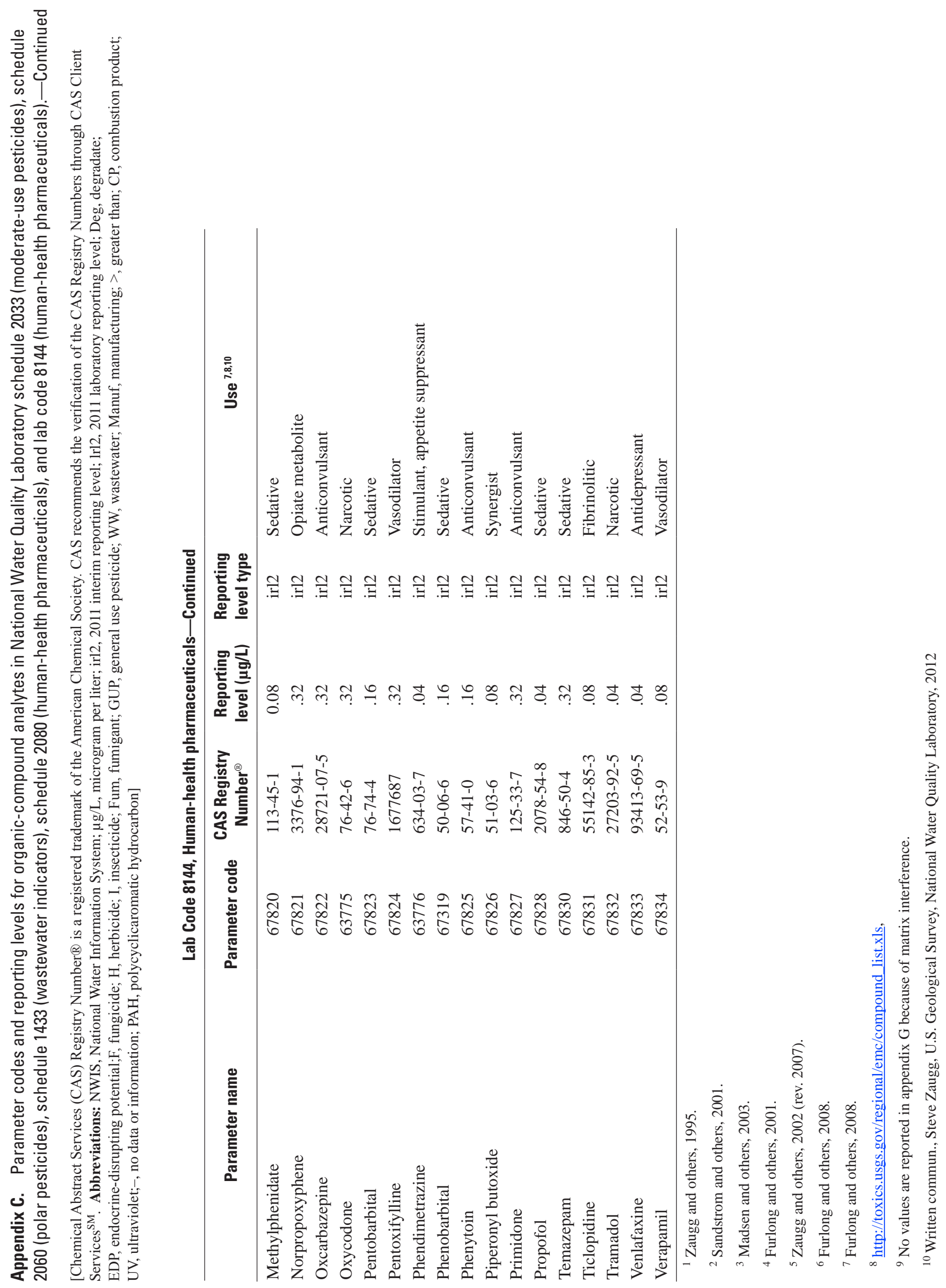


\section{Appendix D. Analytical Results for Quality-Control Samples Collected at White River at Headworks, White River Canal, Lake Tapps Diversion, and Lake Tapps, Washington Study Sites, July-December 2010}

Appendix D1. Concentrations of constituents in field blank samples and replicate samples along with the corresponding environmental concentrations from the White River at Headworks, White River Canal (Inflow), and Lake Tapps Diversion (Tailrace), July-December 2010.

[A bbreviations: nm, nanometer; e, estimated; <, less than; -, no value; all values except turbidity and fecal-coliform bacteria referenced to laboratory long-term method detection levels; NTRU, nephelometric turbidity ratio units]

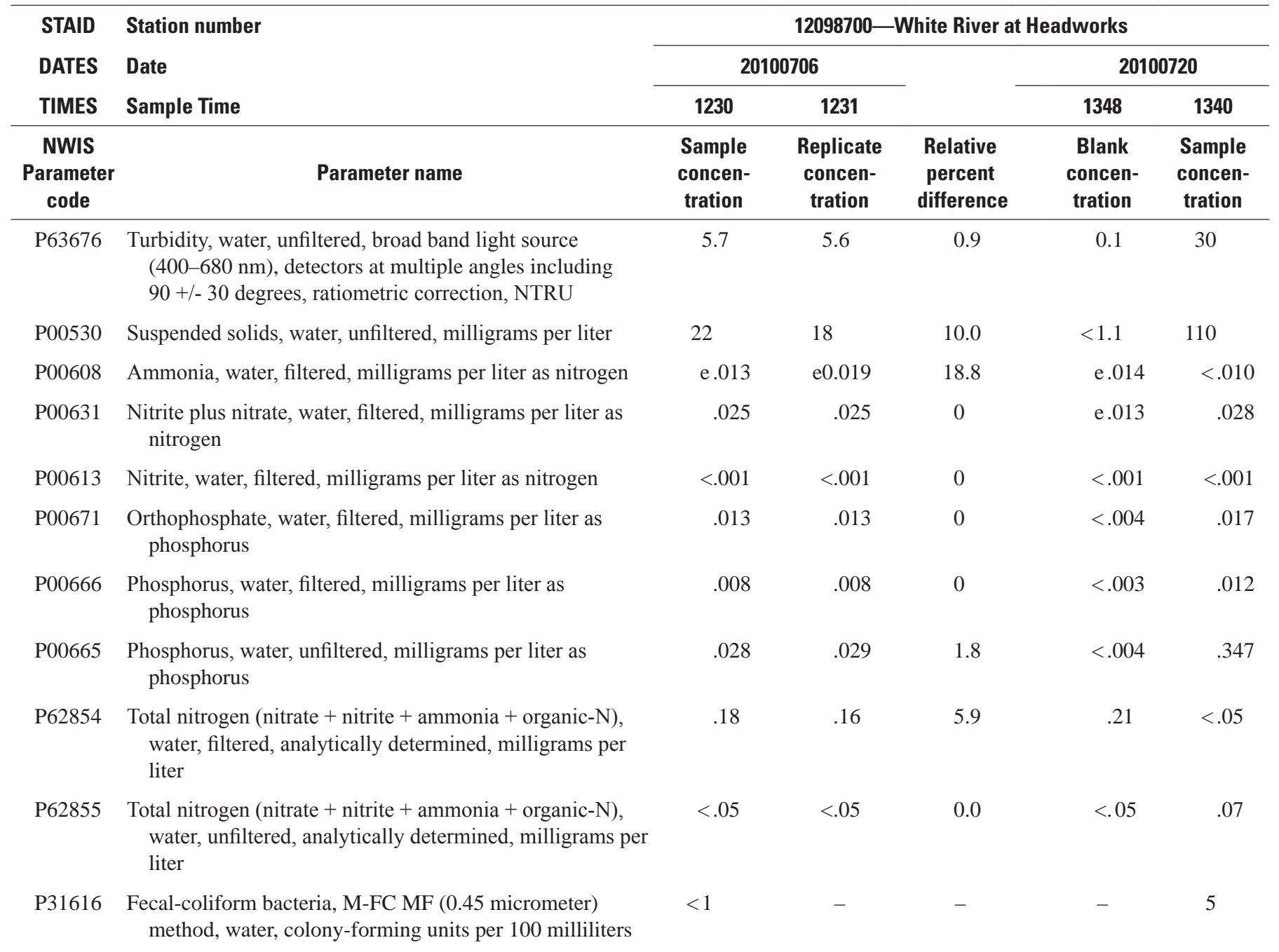


Appendix D1. Concentrations of constituents in field blank samples and replicate samples along with the corresponding environmental concentrations from the White River at Headworks, White River Canal (Inflow), and Lake Tapps Diversion (Tailrace), July-December 2010.-Continued

[A bbreviations: nm, nanometer; e, estimated; <, less than; -, no value; all values except turbudity and fecal-coliform bacteria referenced to laboratory long-term method detection levels; NTRU, nephelometric turbidity ratio units]

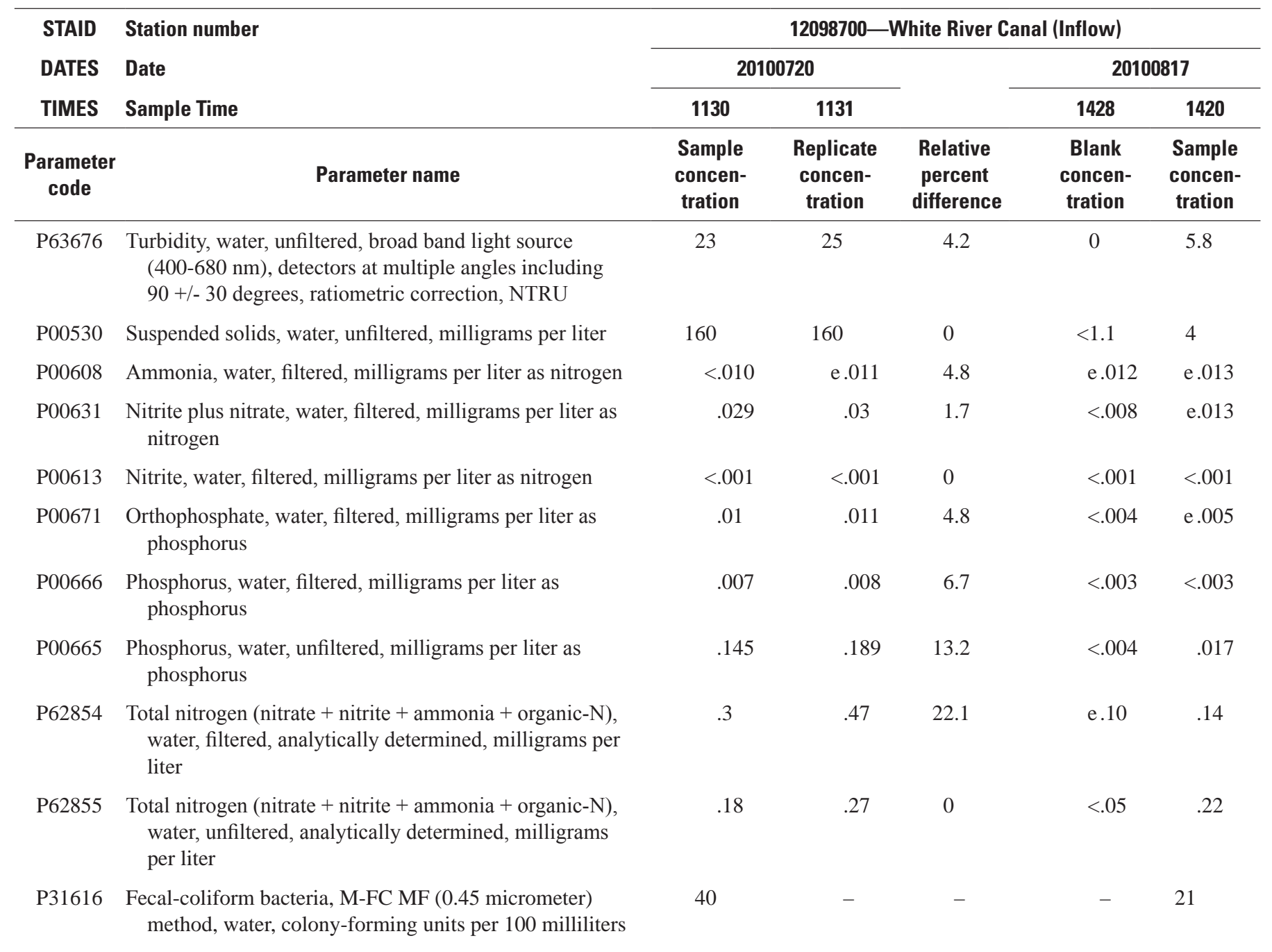


Appendix D1. Concentrations of constituents in field blank samples and replicate samples along with the corresponding environmental concentrations from the White River at Headworks, White River Canal (Inflow), and Lake Tapps Diversion (Tailrace), July-December 2010.-Continued

[A bbreviations: nm, nanometer; e, estimated; <, less than; -, no value; all values except turbidity and fecal-coliform bacteria referenced to laboratory long-term method detection levels; NTRU, nephelometric turbidity ratio units]

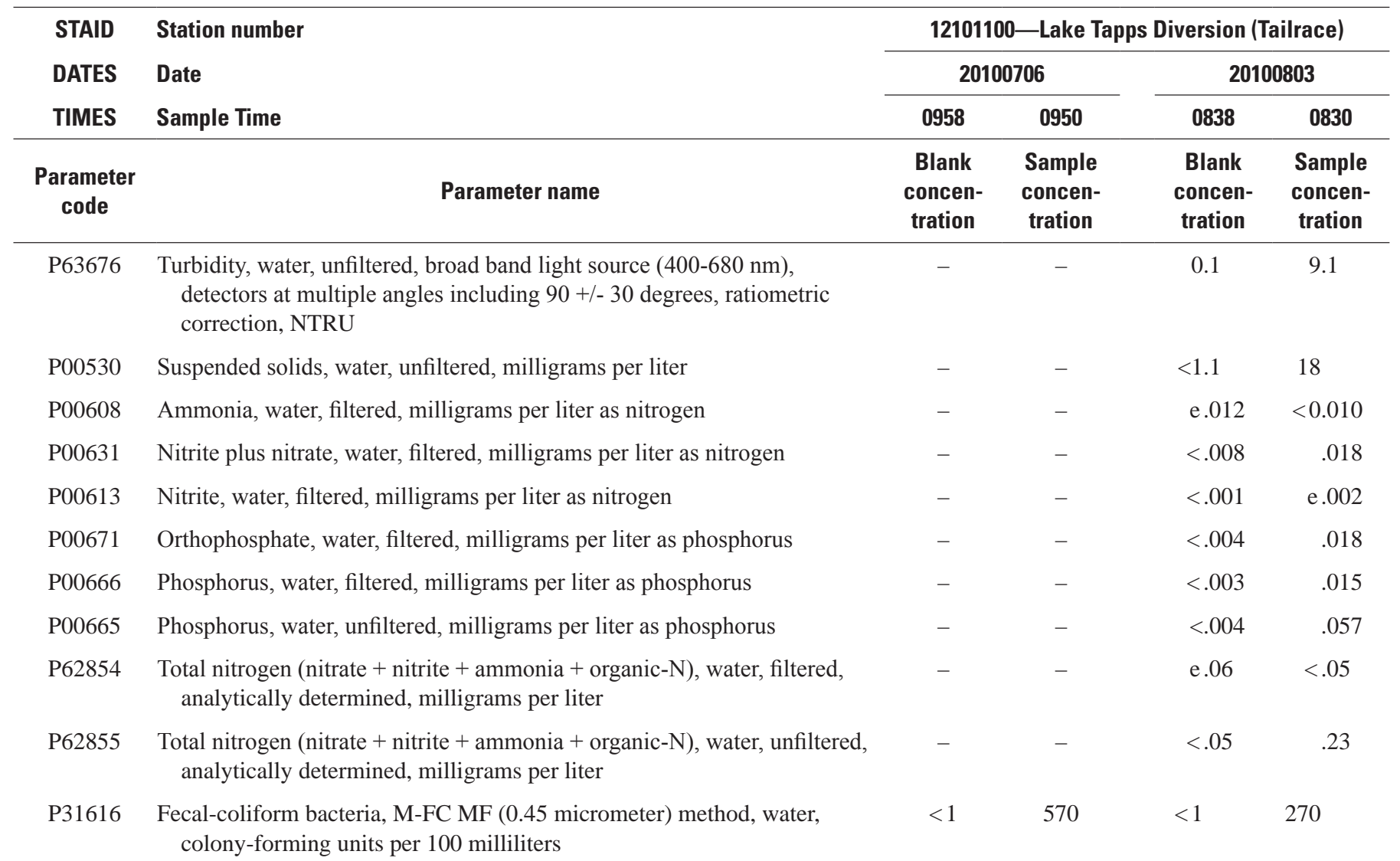


Appendix D1. Concentrations of constituents in field blank samples and replicate samples along with the corresponding environmental concentrations from the White River at Headworks, White River Canal (Inflow), and Lake Tapps Diversion (Tailrace), July-December 2010.-Continued

[A bbreviations: nm, nanometer; e, estimated; <, less than; -, no value; all values except turbidity and fecal-coliform bacteria referenced to laboratory long-term method detection levels; NTRU, nephelometric turbidity ratio units]

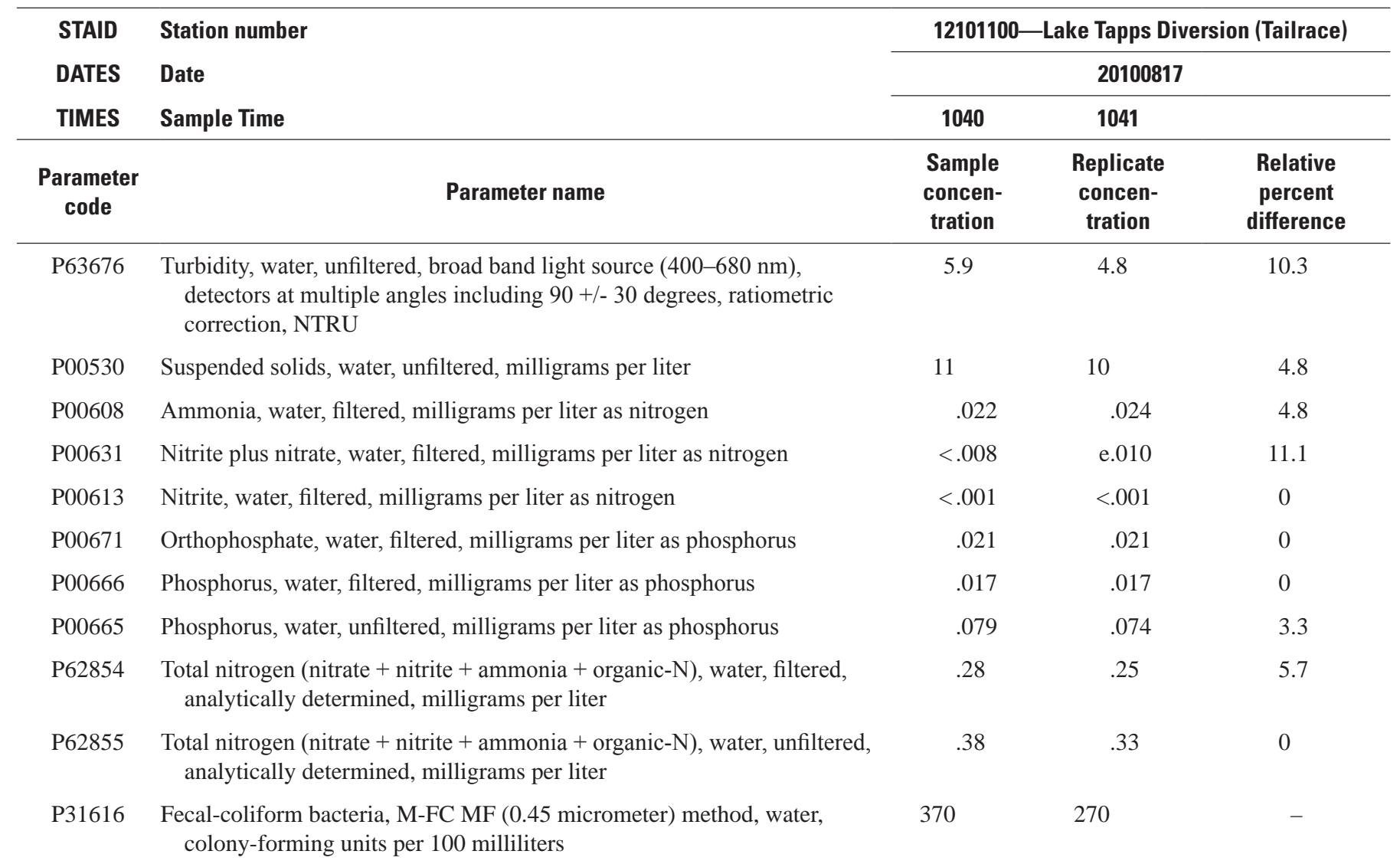


Appendix D1. Concentrations of constituents in field blank samples and replicate samples along with the corresponding environmental concentrations from the White River at Headworks, White River Canal (Inflow), and Lake Tapps Diversion (Tailrace), July-December 2010.-Continued

[A bbreviations: nm, nanometer; e, estimated; <, less than; -, no value; all values except turbidity and fecal-coliform bacteria referenced to laboratory long-term method detection levels; NTRU, nephelometric turbidity ratio units]

\begin{tabular}{|c|c|c|c|c|c|c|}
\hline \multirow{3}{*}{$\begin{array}{l}\text { STAID } \\
\text { DATES } \\
\text { TIMES }\end{array}$} & \multirow{3}{*}{$\begin{array}{l}\text { Station number } \\
\text { Date } \\
\text { Sample Time }\end{array}$} & \multicolumn{5}{|c|}{ 12101100—Lake Tapps Diversion (Tailrace) } \\
\hline & & \multicolumn{5}{|c|}{20101116} \\
\hline & & 1040 & 1041 & & 1048 & 1040 \\
\hline $\begin{array}{l}\text { Parameter } \\
\text { code }\end{array}$ & Parameter name & $\begin{array}{l}\text { Sample } \\
\text { concen- } \\
\text { tration }\end{array}$ & $\begin{array}{l}\text { Replicate } \\
\text { concen- } \\
\text { tration }\end{array}$ & $\begin{array}{l}\text { Relative } \\
\text { percent } \\
\text { difference }\end{array}$ & $\begin{array}{l}\text { Blank } \\
\text { concen- } \\
\text { tration }\end{array}$ & $\begin{array}{l}\text { Sample } \\
\text { concen- } \\
\text { tration }\end{array}$ \\
\hline P63676 & $\begin{array}{l}\text { Turbidity, water, unfiltered, broad band light source (400- } \\
680 \mathrm{~nm} \text { ), detectors at multiple angles including } 90+/-30 \\
\text { degrees, ratiometric correction, NTRU }\end{array}$ & 2.5 & 2.4 & 2.0 & 0.1 & 2.5 \\
\hline P00530 & Suspended solids, water, unfiltered, milligrams per liter & $<1.1$ & e 1.2 & 4.3 & $<1.1$ & $<1.1$ \\
\hline P00608 & Ammonia, water, filtered, milligrams per liter as nitrogen & .018 & .018 & 4.8 & .018 & .018 \\
\hline P00631 & $\begin{array}{l}\text { Nitrite plus nitrate, water, filtered, milligrams per liter as } \\
\text { nitrogen }\end{array}$ & .024 & .026 & 11.1 & $<.008$ & .024 \\
\hline P00613 & Nitrite, water, filtered, milligrams per liter as nitrogen & .002 & .001 & 0 & $<.001$ & .002 \\
\hline P00671 & $\begin{array}{l}\text { Orthophosphate, water, filtered, milligrams per liter as } \\
\text { phosphorus }\end{array}$ & $<.004$ & $<.004$ & 0 & $<.004$ & $<.004$ \\
\hline P00666 & $\begin{array}{l}\text { Phosphorus, water, filtered, milligrams per liter as } \\
\text { phosphorus }\end{array}$ & $<.003$ & $<.003$ & 0 & $<.003$ & $<.003$ \\
\hline P00665 & $\begin{array}{l}\text { Phosphorus, water, unfiltered, milligrams per liter as } \\
\text { phosphorus }\end{array}$ & .008 & .009 & 5.9 & $<.004$ & .008 \\
\hline P62854 & $\begin{array}{l}\text { Total nitrogen }(\text { nitrate }+ \text { nitrite }+ \text { ammonia }+ \text { organic-N), } \\
\text { water, filtered, analytically determined, milligrams per } \\
\text { liter }\end{array}$ & .12 & .13 & 4.0 & $<.05$ & .12 \\
\hline P62855 & $\begin{array}{l}\text { Total nitrogen (nitrate }+ \text { nitrite }+ \text { ammonia }+ \text { organic-N), } \\
\text { water, unfiltered, analytically determined, milligrams per } \\
\text { liter }\end{array}$ & .16 & .17 & 0.0 & $<.05$ & .16 \\
\hline P31616 & $\begin{array}{l}\text { Fecal-coliform bacteria, M-FC MF ( } 0.45 \text { micrometer) } \\
\text { method, water, colony-forming units per } 100 \text { milliliterss }\end{array}$ & 2 & - & - & $<1$ & 2 \\
\hline
\end{tabular}


Appendix D1. Concentrations of constituents in field blank samples and replicate samples along with the corresponding environmental concentrations from the White River at Headworks, White River Canal (Inflow), and Lake Tapps Diversion (Tailrace), July-December 2010.-Continued

[A bbreviations: nm, nanometer; e, estimated; <, less than; -, no value; all values except turbidity and fecal-coliform bacteria referenced to laboratory long-term method detection levels; NTRU, nephelometric turbidity ratio units]

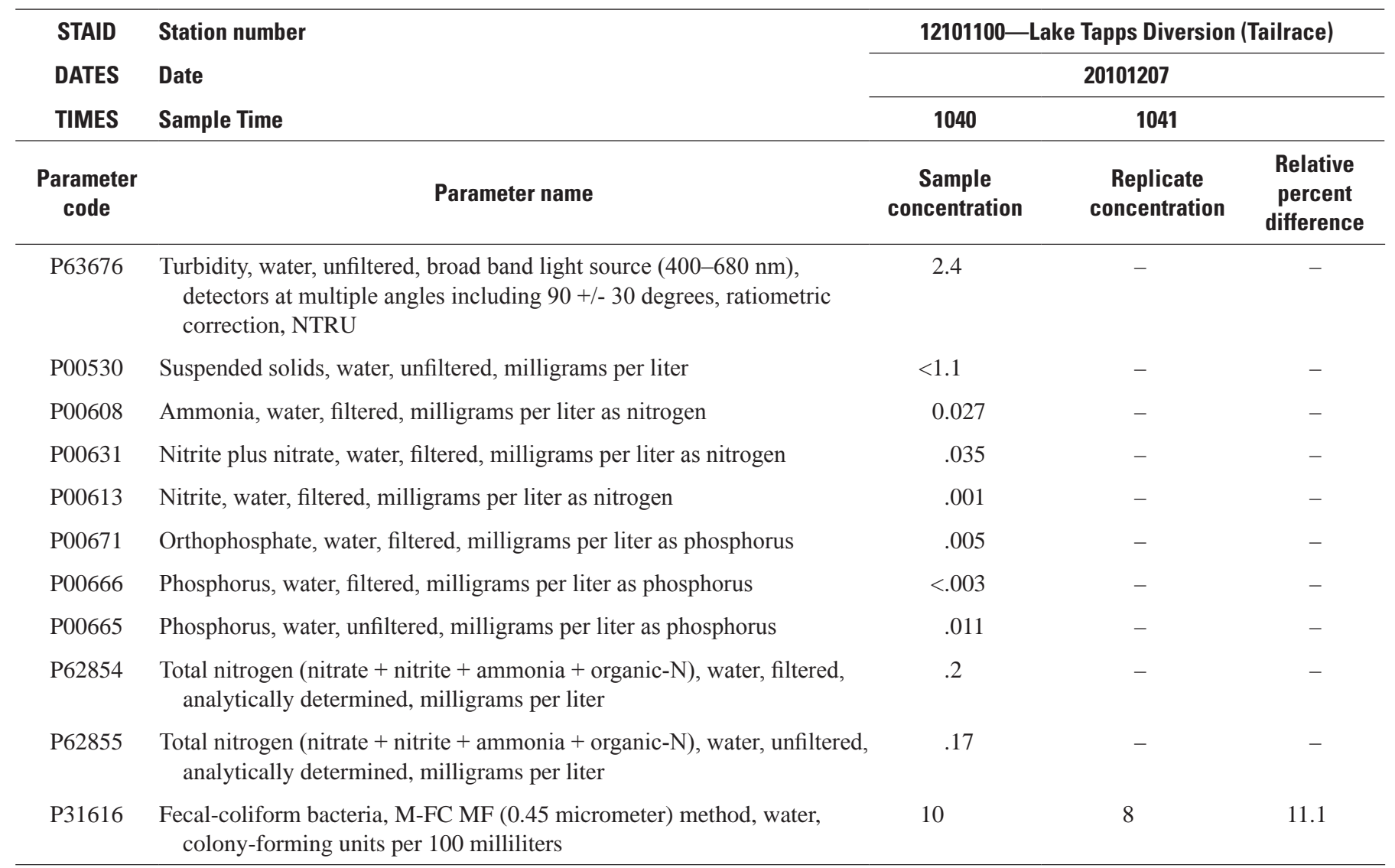


Appendix D2. Concentrations of constituents in field blank samples and replicate samples along with the corresponding environmental concentrations from Lake Tapps study sites, July-December 2010.

[All values except turbidity and fecal-coliform bacteria referenced to laboratory long-term method detection levels Abbreviations: nm, nanometer; <, less than; e, estimated; $\mu \mathrm{g} / \mathrm{L}$, microgram per liter; -, no quality-control sample; NTRU, nephelometric turbidity ratio units]

\begin{tabular}{|c|c|c|c|c|c|c|c|}
\hline \multirow{4}{*}{$\begin{array}{l}\text { STAID } \\
\text { SNAME } \\
\text { DATES } \\
\text { TIMES }\end{array}$} & \multirow{4}{*}{$\begin{array}{l}\text { Station number } \\
\text { Station name } \\
\text { Date } \\
\text { Sample start time }\end{array}$} & \multicolumn{6}{|c|}{471142122094701} \\
\hline & & \multicolumn{6}{|c|}{ EPILIMNION-Allan Yorke (map No. L2) } \\
\hline & & \multicolumn{2}{|c|}{20100803} & \multicolumn{2}{|c|}{20100907} & \multicolumn{2}{|c|}{20100921} \\
\hline & & 0958 & 0950 & 0930 & 0931 & 0910 & 0911 \\
\hline $\begin{array}{l}\text { Parameter } \\
\text { code }\end{array}$ & Parameter name & $\begin{array}{l}\text { Blank } \\
\text { concen- } \\
\text { tration }\end{array}$ & $\begin{array}{l}\text { Sample } \\
\text { concen- } \\
\text { tration }\end{array}$ & $\begin{array}{l}\text { Sample } \\
\text { concen- } \\
\text { tration }\end{array}$ & $\begin{array}{l}\text { Replicate } \\
\text { concen- } \\
\text { tration }\end{array}$ & $\begin{array}{l}\text { Sample } \\
\text { concen- } \\
\text { tration }\end{array}$ & $\begin{array}{c}\text { Replicate } \\
\text { concen- } \\
\text { tration }\end{array}$ \\
\hline P63676 & $\begin{array}{l}\text { Turbidity, water, unfiltered, broad band } \\
\text { light source }(400-680 \mathrm{~nm}), \text { detectors } \\
\text { at multiple angles including } 90+/-30 \\
\text { degrees, ratiometric correction, NTRU }\end{array}$ & 0.2 & 1.5 & 3.6 & - & 1.8 & - \\
\hline P00530 & $\begin{array}{l}\text { Suspended solids, water, unfiltered, } \\
\text { milligrams per liter }\end{array}$ & $<1.1$ & e 2.4 & 5.2 & - & e1.6 & - \\
\hline P00608 & $\begin{array}{l}\text { Ammonia, water, filtered, milligrams per } \\
\text { liter as nitrogen }\end{array}$ & e. 014 & $<.010$ & $<.010$ & - & $<.010$ & - \\
\hline P00631 & $\begin{array}{l}\text { Nitrite plus nitrate, water, filtered, } \\
\text { milligrams per liter as nitrogen }\end{array}$ & $<.008$ & $<.008$ & $<.008$ & - & $<.008$ & - \\
\hline P00613 & $\begin{array}{l}\text { Nitrite, water, filtered, milligrams per liter } \\
\text { as nitrogen }\end{array}$ & $<.001$ & $<.001$ & $<.001$ & - & $<.001$ & - \\
\hline P00671 & $\begin{array}{l}\text { Orthophosphate, water, filtered, milligrams } \\
\text { per liter as phosphorus }\end{array}$ & $<.004$ & $<.004$ & e.004 & - & $<.004$ & - \\
\hline P00666 & $\begin{array}{l}\text { Phosphorus, water, filtered, milligrams per } \\
\text { liter as phosphorus }\end{array}$ & $<.003$ & e. 003 & $<.003$ & - & e.003 & - \\
\hline P00665 & $\begin{array}{l}\text { Phosphorus, water, unfiltered, milligrams } \\
\text { per liter as phosphorus }\end{array}$ & $<.004$ & .008 & .012 & - & .009 & - \\
\hline P62854 & $\begin{array}{l}\text { Total nitrogen (nitrate }+ \text { nitrite }+ \text { ammonia } \\
\quad+\text { organic-N), water, filtered, analytically } \\
\text { determined, milligrams per liter }\end{array}$ & $<.05$ & e. 08 & .11 & - & .12 & - \\
\hline P62855 & $\begin{array}{l}\text { Total nitrogen (nitrate }+ \text { nitrite }+ \text { ammonia } \\
\quad+\text { organic-N), water, unfiltered, } \\
\text { analytically determined, milligrams per } \\
\text { liter }\end{array}$ & .13 & .13 & .17 & - & .13 & - \\
\hline P31616 & $\begin{array}{l}\text { Fecal-coliform bacteria, M-FC MF ( } 0.45 \\
\text { micrometer) method, water, colony- } \\
\text { forming units per } 100 \text { milliliters }\end{array}$ & $<1$ & 3 & 2 & - & 11 & 4 \\
\hline P70953 & $\begin{array}{l}\text { Chlorophyll } a \text {, phytoplankton, } \\
\text { chromatographic-fluorometric method, } \\
\mu \mathrm{g} / \mathrm{L}\end{array}$ & $<.01$ & e 2.1 & e 2.1 & e 2.1 & e 2.2 & - \\
\hline P62360 & Pheophytin $a$, phytoplankton, $\mu \mathrm{g} / \mathrm{L}$ & $<.01$ & e 1.1 & e 1.3 & e 1.2 & e 1.0 & - \\
\hline
\end{tabular}


Appendix D2. Concentrations of constituents in field blank samples and replicate samples along with the corresponding environmental concentrations from Lake Tapps study sites, July-December 2010.—Continued

[All values except turbidity and fecal-coliform bacteria referenced to laboratory long-term method detection levels A bbreviations: nm, nanometer; <, less than; e, estimated; $\mu \mathrm{g} / \mathrm{L}$, microgram per liter; -, no quality-control sample; NTRU, nephelometric turbidity ratio units]

\begin{tabular}{|c|c|c|c|c|c|}
\hline \multirow{4}{*}{$\begin{array}{l}\text { STAID } \\
\text { SNAME } \\
\text { DATES } \\
\text { TIMES }\end{array}$} & \multirow{4}{*}{$\begin{array}{l}\text { Station number } \\
\text { Station name } \\
\text { Date } \\
\text { Sample start time }\end{array}$} & \multicolumn{4}{|c|}{471223122091201} \\
\hline & & \multicolumn{4}{|c|}{ EPILIMNION-Lake Inlet (map No. L6) } \\
\hline & & \multicolumn{2}{|c|}{20100720} & \multicolumn{2}{|c|}{20101207} \\
\hline & & 1508 & 1500 & 1228 & 1220 \\
\hline $\begin{array}{l}\text { Parameter } \\
\text { code }\end{array}$ & Parameter name & $\begin{array}{l}\text { Blank } \\
\text { concen- } \\
\text { tration }\end{array}$ & $\begin{array}{l}\text { Sample } \\
\text { concen- } \\
\text { tration }\end{array}$ & $\begin{array}{l}\text { Blank } \\
\text { concen- } \\
\text { tration }\end{array}$ & $\begin{array}{l}\text { Sample } \\
\text { concen- } \\
\text { tration }\end{array}$ \\
\hline P63676 & $\begin{array}{l}\text { Turbidity, water, unfiltered, broad band light source }(400-680 \\
\text { nm), detectors at multiple angles including } 90+/-30 \text { degrees, } \\
\text { ratiometric correction, NTRU }\end{array}$ & 0.1 & 1.2 & 0.2 & 1.1 \\
\hline P00530 & Suspended solids, water, unfiltered, milligrams per liter & e1.2 & e 3.2 & $<1.1$ & $<1.1$ \\
\hline P00608 & Ammonia, water, filtered, milligrams per liter as nitrogen & $<.010$ & $<0.010$ & .011 & 0.012 \\
\hline P00631 & Nitrite plus nitrate, water, filtered, milligrams per liter as nitrogen & e. 010 & $<.008$ & $<.008$ & .019 \\
\hline P00613 & Nitrite, water, filtered, milligrams per liter as nitrogen & $<.001$ & $<.001$ & $<.001$ & .001 \\
\hline P00671 & Orthophosphate, water, filtered, milligrams per liter as phosphorus & $<.004$ & $<.004$ & $<.004$ & $<.004$ \\
\hline P00666 & Phosphorus, water, filtered, milligrams per liter as phosphorus & $<.003$ & $<.003$ & $<.003$ & $<.003$ \\
\hline P00665 & Phosphorus, water, unfiltered, milligrams per liter as phosphorus & $<.004$ & e.008 & $<.004$ & .008 \\
\hline P62854 & $\begin{array}{l}\text { Total nitrogen (nitrate }+ \text { nitrite }+ \text { ammonia }+ \text { organic-N), water, } \\
\text { filtered, analytically determined, milligrams per liter }\end{array}$ & $<.05$ & .11 & $<.05$ & .17 \\
\hline P62855 & $\begin{array}{l}\text { Total nitrogen (nitrate }+ \text { nitrite }+ \text { ammonia }+ \text { organic-N), water, } \\
\text { unfiltered, analytically determined, milligrams per liter }\end{array}$ & $<.05$ & .14 & $<.05$ & .18 \\
\hline P31616 & $\begin{array}{l}\text { Fecal-coliform bacteria, M-FC MF ( } 0.45 \text { micrometer) method, water, } \\
\text { colony-forming units per } 100 \text { milliliters }\end{array}$ & $<1$ & e 1 & - & e 1 \\
\hline P70953 & $\begin{array}{l}\text { Chlorophyll a, phytoplankton, chromatographic-fluorometric method, } \\
\mu \mathrm{g} / \mathrm{L}\end{array}$ & $<.01$ & e1.5 & - & e 3.5 \\
\hline P62360 & Pheophytin $a$, phytoplankton, $\mu \mathrm{g} / \mathrm{L}$ & $<.01$ & e.7 & - & e.9 \\
\hline
\end{tabular}


Appendix D2. Concentrations of constituents in field blank samples and replicate samples along with the corresponding environmental concentrations from Lake Tapps study sites, July-December 2010.—Continued

[All values except turbidity and fecal-coliform bacteria referenced to laboratory long-term method detection levels Abbreviations: nm, nanometer; <, less than; e, estimated; $\mu \mathrm{g} / \mathrm{L}$, microgram per liter; -, no quality-control sample; NTRU, nephelometric turbidity ratio units]

\begin{tabular}{|c|c|c|c|c|c|}
\hline \multirow{4}{*}{$\begin{array}{l}\text { STAID } \\
\text { SNAME } \\
\text { DATES } \\
\text { TIMES }\end{array}$} & \multirow{4}{*}{$\begin{array}{l}\text { Station number } \\
\text { Station name } \\
\text { Date } \\
\text { Sample start time }\end{array}$} & \multicolumn{4}{|c|}{471241122084401} \\
\hline & & \multicolumn{4}{|c|}{ EPILIMNION-Southeast Arm (map No. L7) } \\
\hline & & \multicolumn{2}{|c|}{20100921} & \multicolumn{2}{|c|}{20101026} \\
\hline & & 1258 & 1250 & 1118 & 1110 \\
\hline $\begin{array}{l}\text { Parameter } \\
\text { code }\end{array}$ & Parameter name & $\begin{array}{l}\text { Blank } \\
\text { concen- } \\
\text { tration }\end{array}$ & $\begin{array}{l}\text { Sample } \\
\text { concen- } \\
\text { tration }\end{array}$ & $\begin{array}{l}\text { Blank } \\
\text { concen- } \\
\text { tration }\end{array}$ & $\begin{array}{c}\text { Sample } \\
\text { concen- } \\
\text { tration }\end{array}$ \\
\hline P63676 & $\begin{array}{l}\text { Turbidity, water, unfiltered, broad band light source ( } 400-680 \\
\text { nm), detectors at multiple angles including } 90+/-30 \text { degrees, } \\
\text { ratiometric correction, NTRU }\end{array}$ & 0.1 & 3.2 & - & 3.9 \\
\hline P00530 & Suspended solids, water, unfiltered, milligrams per liter & $<1.1$ & e3.6 & - & 4 \\
\hline P00608 & Ammonia, water, filtered, milligrams per liter as nitrogen & $<.010$ & $<.010$ & - & $<.010$ \\
\hline P00631 & Nitrite plus nitrate, water, filtered, milligrams per liter as nitrogen & $<.008$ & $<.008$ & - & $<.008$ \\
\hline P00613 & Nitrite, water, filtered, milligrams per liter as nitrogen & $<.001$ & $<.001$ & - & $<.001$ \\
\hline P00671 & Orthophosphate, water, filtered, milligrams per liter as phosphorus & $<.004$ & $<.004$ & - & $<.004$ \\
\hline P00666 & Phosphorus, water, filtered, milligrams per liter as phosphorus & $<.003$ & e. 003 & - & $<.003$ \\
\hline P00665 & Phosphorus, water, unfiltered, milligrams per liter as phosphorus & $<.004$ & .011 & - & .013 \\
\hline P62854 & $\begin{array}{l}\text { Total nitrogen (nitrate }+ \text { nitrite }+ \text { ammonia }+ \text { organic- }-\mathrm{N}) \text {, water, } \\
\quad \text { filtered, analytically determined, milligrams per liter }\end{array}$ & $<.05$ & .11 & - & .12 \\
\hline P62855 & $\begin{array}{l}\text { Total nitrogen (nitrate }+ \text { nitrite }+ \text { ammonia }+ \text { organic- } \mathrm{N} \text { ), water, } \\
\text { unfiltered, analytically determined, milligrams per liter }\end{array}$ & $<.05$ & .16 & - & .18 \\
\hline P31616 & $\begin{array}{l}\text { Fecal-coliform bacteria, M-FC MF ( } 0.45 \text { micrometer) method, } \\
\text { water, colony-forming units per } 100 \text { milliliters }\end{array}$ & - & $<1$ & $<1$ & $<1$ \\
\hline P70953 & $\begin{array}{l}\text { Chlorophyll } a \text {, phytoplankton, chromatographic-fluorometric } \\
\text { method, } \mu \mathrm{g} / \mathrm{L}\end{array}$ & - & e 2.0 & - & e 4.5 \\
\hline P62360 & Pheophytin $a$, phytoplankton, $\mu \mathrm{g} / \mathrm{L}$ & - & e. 9 & - & e 1.3 \\
\hline
\end{tabular}


Appendix D2. Concentrations of constituents in field blank samples and replicate samples along with the corresponding environmental concentrations from Lake Tapps study sites, July-December 2010.—Continued

[All values except turbidity and fecal-coliform bacteria referenced to laboratory long-term method detection levels A bbreviations: nm, nanometer; <, less than; e, estimated; $\mu \mathrm{g} / \mathrm{L}$, microgram per liter; -, no quality-control sample; NTRU, nephelometric turbidity ratio units]

\begin{tabular}{|c|c|c|c|c|c|c|c|}
\hline \multirow{4}{*}{$\begin{array}{l}\text { STAID } \\
\text { SNAME } \\
\text { DATES } \\
\text { TIMES }\end{array}$} & \multirow{4}{*}{$\begin{array}{l}\text { Station number } \\
\text { Station name } \\
\text { Date } \\
\text { Sample start time }\end{array}$} & \multicolumn{4}{|c|}{471324122093901} & \multicolumn{2}{|c|}{471324122093902} \\
\hline & & \multicolumn{4}{|c|}{ EPILIMNION-Snag Island (map No. L5) } & \multirow{2}{*}{\multicolumn{2}{|c|}{$\begin{array}{c}\text { HYPOLIMNION-Snag Island (L5) } \\
20101013\end{array}$}} \\
\hline & & \multicolumn{2}{|c|}{20100707} & \multicolumn{2}{|c|}{20101013} & & \\
\hline & & 1408 & 1400 & 1300 & 1301 & 1310 & 1311 \\
\hline $\begin{array}{l}\text { Parameter } \\
\text { code }\end{array}$ & Parameter name & $\begin{array}{l}\text { Blank } \\
\text { concen- } \\
\text { tration }\end{array}$ & $\begin{array}{l}\text { Sample } \\
\text { concen- } \\
\text { tration }\end{array}$ & $\begin{array}{l}\text { Sample } \\
\text { concen- } \\
\text { tration }\end{array}$ & $\begin{array}{l}\text { Replicate } \\
\text { concen- } \\
\text { tration }\end{array}$ & $\begin{array}{l}\text { Sample } \\
\text { concen- } \\
\text { tration }\end{array}$ & $\begin{array}{l}\text { Replicate } \\
\text { concen- } \\
\text { tration }\end{array}$ \\
\hline P63676 & $\begin{array}{l}\text { Turbidity, water, unfiltered, broad } \\
\text { band light source (400-680 } \\
\text { nm), detectors at multiple angles } \\
\text { including } 90+/-30 \text { degrees, } \\
\text { ratiometric correction, NTRU }\end{array}$ & 0.2 & 0.7 & 2.7 & 2.3 & 7.6 & 7.5 \\
\hline P00530 & $\begin{array}{l}\text { Suspended solids, water, unfiltered, } \\
\text { milligrams per liter }\end{array}$ & $<1.1$ & $\mathrm{e} 1.2$ & e 1.6 & $\mathrm{e} 1.2$ & 7.2 & 8 \\
\hline P00608 & $\begin{array}{l}\text { Ammonia, water, filtered, milligrams } \\
\text { per liter as nitrogen }\end{array}$ & $<.010$ & $<.010$ & .026 & .025 & .849 & .846 \\
\hline P00631 & $\begin{array}{l}\text { Nitrite plus nitrate, water, filtered, } \\
\text { milligrams per liter as nitrogen }\end{array}$ & $<.008$ & $<.008$ & $<.008$ & $<.008$ & $<.008$ & $<.008$ \\
\hline P00613 & $\begin{array}{l}\text { Nitrite, water, filtered, milligrams } \\
\text { per liter as nitrogen }\end{array}$ & $<.001$ & $<.001$ & $<.001$ & $<.001$ & .003 & .003 \\
\hline P00671 & $\begin{array}{l}\text { Orthophosphate, water, filtered, } \\
\text { milligrams per liter as phosphorus }\end{array}$ & $<.004$ & $<.004$ & $<.004$ & $<.004$ & .006 & .007 \\
\hline P00666 & $\begin{array}{l}\text { Phosphorus, water, filtered, } \\
\text { milligrams per liter as phosphorus }\end{array}$ & $<.003$ & $<.003$ & $<.003$ & $<.003$ & .006 & .006 \\
\hline P00665 & $\begin{array}{l}\text { Phosphorus, water, unfiltered, } \\
\text { milligrams per liter as phosphorus }\end{array}$ & $<.004$ & e.006 & .007 & .007 & .021 & .021 \\
\hline P62854 & $\begin{array}{l}\text { Total nitrogen (nitrate }+ \text { nitrite }+ \\
\text { ammonia }+ \text { organic-N), water, } \\
\text { filtered, analytically determined, } \\
\text { milligrams per liter }\end{array}$ & $<.05$ & .1 & .12 & .13 & 1.1 & 1.01 \\
\hline P62855 & $\begin{array}{l}\text { Total nitrogen (nitrate }+ \text { nitrite } \\
\quad+\text { ammonia }+ \text { organic-N), } \\
\text { water, unfiltered, analytically } \\
\text { determined, milligrams per liter }\end{array}$ & $<.05$ & .13 & .16 & .14 & 1.4 & 1.2 \\
\hline P31616 & $\begin{array}{l}\text { Fecal-coliform bacteria, M-FC MF } \\
\text { ( } 0.45 \text { micrometer) method, water, } \\
\text { colony-forming units per } 100 \\
\text { milliliters }\end{array}$ & - & $<1$ & 2 & - & - & - \\
\hline P70953 & $\begin{array}{l}\text { Chlorophyll } a \text {, phytoplankton, } \\
\text { chromatographic-fluorometric } \\
\text { method, } \mu \mathrm{g} / \mathrm{L}\end{array}$ & $<.01$ & e. 6 & e1.0 & e1.0 & - & - \\
\hline P62360 & Pheophytin $a$, phytoplankton, $\mu \mathrm{g} / \mathrm{L}$ & $<.01$ & e.3 & e.6 & e.6 & - & - \\
\hline
\end{tabular}


Appendix D2. Concentrations of constituents in field blank samples and replicate samples along with the corresponding environmental concentrations from Lake Tapps study sites, July-December 2010.—Continued

[All values except turbidity and fecal-coliform bacteria referenced to laboratory long-term method detection levels A bbreviations: nm, nanometer; <, less than; e, estimated; $\mu \mathrm{g} / \mathrm{L}$, microgram per liter; -, no quality-control sample; NTRU, nephelometric turbidity ratio units]

\begin{tabular}{|c|c|c|c|}
\hline STAID & Station number & \multicolumn{2}{|c|}{471358122085201} \\
\hline SNAME & Station name & \multicolumn{2}{|c|}{ EPILIMNION-Northeast Arm (map No. L3) } \\
\hline DATES & Date & \multicolumn{2}{|c|}{20100922} \\
\hline TIMES & Sample start time & 1458 & 1450 \\
\hline $\begin{array}{l}\text { Parameter } \\
\text { code }\end{array}$ & Parameter name & $\begin{array}{l}\text { Blank } \\
\text { concen- } \\
\text { tration }\end{array}$ & $\begin{array}{l}\text { Sample } \\
\text { concen- } \\
\text { tration }\end{array}$ \\
\hline P63676 & $\begin{array}{l}\text { Turbidity, water, unfiltered, broad band light source }(400-680 \mathrm{~nm}) \text {, detectors } \\
\text { at multiple angles including } 90+/-30 \text { degrees, ratiometric correction, } \\
\text { NTRU }\end{array}$ & 0.1 & 0.7 \\
\hline P00530 & Suspended solids, water, unfiltered, milligrams per liter & $<1.1$ & $<1.1$ \\
\hline P00608 & Ammonia, water, filtered, milligrams per liter as nitrogen & $<.010$ & $<.010$ \\
\hline P00631 & Nitrite plus nitrate, water, filtered, milligrams per liter as nitrogen & $<.008$ & $<.008$ \\
\hline P00613 & Nitrite, water, filtered, milligrams per liter as nitrogen & $<.001$ & $<.001$ \\
\hline P00671 & Orthophosphate, water, filtered, milligrams per liter as phosphorus & $<.004$ & $<.004$ \\
\hline P00666 & Phosphorus, water, filtered, milligrams per liter as phosphorus & $<.003$ & $<.003$ \\
\hline P00665 & Phosphorus, water, unfiltered, milligrams per liter as phosphorus & $<.004$ & $<.004$ \\
\hline P62854 & $\begin{array}{l}\text { Total nitrogen (nitrate }+ \text { nitrite }+ \text { ammonia }+ \text { organic-N), water, filtered, } \\
\text { analytically determined, milligrams per liter }\end{array}$ & $<.05$ & .11 \\
\hline P62855 & $\begin{array}{l}\text { Total nitrogen (nitrate }+ \text { nitrite }+ \text { ammonia }+ \text { organic- } \mathrm{N}) \text {, water, unfiltered, } \\
\text { analytically determined, milligrams per liter }\end{array}$ & $<.05$ & .12 \\
\hline P31616 & $\begin{array}{l}\text { Fecal-coliform bacteria, M-FC MF ( } 0.45 \text { micrometer) method, water, colony- } \\
\text { forming units per } 100 \text { milliliters }\end{array}$ & - & 2 \\
\hline P70953 & Chlorophyll $a$, phytoplankton, chromatographic-fluorometric method, $\mu \mathrm{g} / \mathrm{L}$ & - & e.7 \\
\hline P62360 & Pheophytin $a$, phytoplankton, $\mu \mathrm{g} / \mathrm{L}$ & - & e. 2 \\
\hline
\end{tabular}


Appendix D2. Concentrations of constituents in field blank samples and replicate samples along with the corresponding environmental concentrations from Lake Tapps study sites, July-December 2010.—Continued

[All values except turbidity and fecal-coliform bacteria referenced to laboratory long-term method detection levels A bbreviations: nm, nanometer; <, less than; e, estimated; $\mu \mathrm{g} / \mathrm{L}$, microgram per liter; -, no quality-control sample; NTRU, nephelometric turbidity ratio units]

\begin{tabular}{|c|c|c|c|c|c|c|c|}
\hline \multirow{4}{*}{$\begin{array}{l}\text { STAID } \\
\text { SNAME } \\
\text { DATES } \\
\text { TIMES }\end{array}$} & \multirow{4}{*}{$\begin{array}{l}\text { Station number } \\
\text { Station name } \\
\text { Date } \\
\text { Sample start time }\end{array}$} & \multicolumn{6}{|c|}{471405122093301} \\
\hline & & \multicolumn{6}{|c|}{ EPILIMNION-Tapps Island (map No. L4) } \\
\hline & & \multicolumn{2}{|c|}{20100804} & \multicolumn{2}{|c|}{20100908} & \multicolumn{2}{|c|}{20101027} \\
\hline & & 1200 & 1201 & 1128 & 1120 & 0908 & 0900 \\
\hline $\begin{array}{l}\text { Parameter } \\
\text { code }\end{array}$ & Parameter name & $\begin{array}{l}\text { Sample } \\
\text { concen- } \\
\text { tration }\end{array}$ & $\begin{array}{l}\text { Replicate } \\
\text { concen- } \\
\text { tration }\end{array}$ & $\begin{array}{l}\text { Blank } \\
\text { concen- } \\
\text { tration }\end{array}$ & $\begin{array}{l}\text { Sample } \\
\text { concen- } \\
\text { tration }\end{array}$ & $\begin{array}{l}\text { Blank } \\
\text { concen- } \\
\text { tration }\end{array}$ & $\begin{array}{l}\text { Sample } \\
\text { concen- } \\
\text { tration }\end{array}$ \\
\hline P63676 & $\begin{array}{l}\text { Turbidity, water, unfiltered, broad band light } \\
\text { source }(400-680 \mathrm{~nm}) \text {, detectors at multiple } \\
\text { angles including } 90+/-30 \text { degrees, } \\
\text { ratiometric correction, NTRU }\end{array}$ & 0.7 & 0.7 & 0.1 & 1.8 & 0.1 & 1.6 \\
\hline P00530 & $\begin{array}{l}\text { Suspended solids, water, unfiltered, } \\
\text { milligrams per liter }\end{array}$ & $<1.1$ & $<1.1$ & $<1.1$ & $<1.1$ & $<1.1$ & e 1.6 \\
\hline P00608 & $\begin{array}{l}\text { Ammonia, water, filtered, milligrams per liter } \\
\text { as nitrogen }\end{array}$ & $<.010$ & $<.010$ & $<.010$ & $<.010$ & $<.010$ & $<.010$ \\
\hline P00631 & $\begin{array}{l}\text { Nitrite plus nitrate, water, filtered, milligrams } \\
\text { per liter as nitrogen }\end{array}$ & $<.008$ & $<.008$ & $<.008$ & $<.008$ & $<.008$ & $<.008$ \\
\hline P00613 & $\begin{array}{l}\text { Nitrite, water, filtered, milligrams per liter as } \\
\text { nitrogen }\end{array}$ & $<.001$ & $<.001$ & $<.001$ & $<.001$ & $<.001$ & $<.001$ \\
\hline P00671 & $\begin{array}{l}\text { Orthophosphate, water, filtered, milligrams } \\
\text { per liter as phosphorus }\end{array}$ & $<.004$ & $<.004$ & $<.004$ & e.004 & $<.004$ & $<.004$ \\
\hline P00666 & $\begin{array}{l}\text { Phosphorus, water, filtered, milligrams per } \\
\text { liter as phosphorus }\end{array}$ & $<.003$ & e.003 & $<.003$ & $<.003$ & $<.003$ & $<.003$ \\
\hline P00665 & $\begin{array}{l}\text { Phosphorus, water, unfiltered, milligrams per } \\
\text { liter as phosphorus }\end{array}$ & e.005 & e. 004 & $<.004$ & e. 005 & $<.004$ & .005 \\
\hline P62854 & $\begin{array}{l}\text { Total nitrogen (nitrate }+ \text { nitrite }+ \text { ammonia } \\
+ \text { organic-N), water, filtered, analytically } \\
\text { determined, milligrams per liter }\end{array}$ & e.09 & e. 07 & $<.05$ & .12 & $<.05$ & .12 \\
\hline P62855 & $\begin{array}{l}\text { Total nitrogen (nitrate }+ \text { nitrite }+ \text { ammonia }+ \\
\text { organic-N), water, unfiltered, analytically } \\
\text { determined, milligrams per liter }\end{array}$ & .12 & 0.11 & $<.05$ & .14 & $<.05$ & .14 \\
\hline P31616 & $\begin{array}{l}\text { Fecal-coliform bacteria, M-FC MF ( } 0.45 \\
\text { micrometer) method, water, colony- } \\
\text { forming units per } 100 \text { milliliters }\end{array}$ & $<1$ & - & - & 12 & - & 5 \\
\hline P70953 & $\begin{array}{l}\text { Chlorophyll } a \text {, phytoplankton, } \\
\text { chromatographic-fluorometric method, } \\
\mu \mathrm{g} / \mathrm{L}\end{array}$ & e1.1 & e 1.0 & - & e. 7 & - & e 1.0 \\
\hline P62360 & Pheophytin $a$, phytoplankton, $\mu \mathrm{g} / \mathrm{L}$ & e. 3 & e. 3 & - & e. 5 & - & e. 5 \\
\hline
\end{tabular}


Appendix D2. Concentrations of constituents in field blank samples and replicate samples along with the corresponding environmental concentrations from Lake Tapps study sites, July-December 2010.—Continued

[All values except turbidity and fecal-coliform bacteria referenced to laboratory long-term method detection levels Abbreviations: nm, nanometer; <, less than; e, estimated; $\mu \mathrm{g} / \mathrm{L}$, microgram per liter; -, no quality-control sample; NTRU, nephelometric turbidity ratio units]

\begin{tabular}{|c|c|c|c|c|c|c|c|}
\hline \multirow{4}{*}{$\begin{array}{l}\text { STAID } \\
\text { SNAME } \\
\text { DATES } \\
\text { TIMES }\end{array}$} & \multirow{4}{*}{$\begin{array}{l}\text { Station number } \\
\text { Station name } \\
\text { Date } \\
\text { Sample start time }\end{array}$} & \multirow{3}{*}{\multicolumn{2}{|c|}{$\begin{array}{c}\frac{471405122093302}{2} \\
\begin{array}{c}\text { HYPOLIMNION-Tapps Island } \\
\text { (map No. L4) }\end{array} \\
20100804\end{array}$}} & \multirow{2}{*}{\multicolumn{4}{|c|}{$\begin{array}{c}471418122121101 \\
\text { EPILIMNION-Deep (map No. L1) }\end{array}$}} \\
\hline & & & & & & & \\
\hline & & & & \multicolumn{2}{|c|}{20100817} & \multicolumn{2}{|c|}{20100907} \\
\hline & & 1210 & 1211 & 1100 & 1101 & 1048 & 1040 \\
\hline $\begin{array}{l}\text { Parameter } \\
\text { code }\end{array}$ & Parameter name & $\begin{array}{l}\text { Sample } \\
\text { concen- } \\
\text { tration }\end{array}$ & $\begin{array}{l}\text { Replicate } \\
\text { concen- } \\
\text { tration }\end{array}$ & $\begin{array}{l}\text { Sample } \\
\text { concen- } \\
\text { tration }\end{array}$ & $\begin{array}{l}\text { Replicate } \\
\text { concen- } \\
\text { tration }\end{array}$ & $\begin{array}{l}\text { Blank } \\
\text { concen- } \\
\text { tration }\end{array}$ & $\begin{array}{l}\text { Sample } \\
\text { concen- } \\
\text { tration }\end{array}$ \\
\hline P63676 & $\begin{array}{l}\text { Turbidity, water, unfiltered, broad band } \\
\text { light source }(400-680 \mathrm{~nm}) \text {, detectors } \\
\text { at multiple angles including } 90+/-30 \\
\text { degrees, ratiometric correction, NTRU }\end{array}$ & 2.4 & 4 & 0.6 & 0.7 & 0.1 & 0.8 \\
\hline P00530 & $\begin{array}{l}\text { Suspended solids, water, unfiltered, } \\
\text { milligrams per liter }\end{array}$ & e 2.0 & e 2.0 & $<1.1$ & $<1.1$ & $<1.1$ & e 3.2 \\
\hline P00608 & $\begin{array}{l}\text { Ammonia, water, filtered, milligrams per } \\
\text { liter as nitrogen }\end{array}$ & .034 & .031 & e.011 & e. 011 & $<.010$ & $<.010$ \\
\hline P00631 & $\begin{array}{l}\text { Nitrite plus nitrate, water, filtered, } \\
\text { milligrams per liter as nitrogen }\end{array}$ & $<.008$ & $<.008$ & $<.008$ & $<.008$ & $<.008$ & $<.008$ \\
\hline P00613 & $\begin{array}{l}\text { Nitrite, water, filtered, milligrams per } \\
\text { liter as nitrogen }\end{array}$ & $<.001$ & $<.001$ & $<.001$ & $<.001$ & $<.001$ & $<.001$ \\
\hline P00671 & $\begin{array}{l}\text { Orthophosphate, water, filtered, } \\
\text { milligrams per liter as phosphorus }\end{array}$ & $<.004$ & $<.004$ & e. .004 & e. 005 & $<.004$ & e. 005 \\
\hline P00666 & $\begin{array}{l}\text { Phosphorus, water, filtered, milligrams } \\
\text { per liter as phosphorus }\end{array}$ & e. 004 & e. 005 & $<.003$ & $<.003$ & $<.003$ & $<.003$ \\
\hline P00665 & $\begin{array}{l}\text { Phosphorus, water, unfiltered, milligrams } \\
\text { per liter as phosphorus }\end{array}$ & .014 & .015 & $<.004$ & $<.004$ & $<.004$ & e. 004 \\
\hline P62854 & $\begin{array}{l}\text { Total nitrogen (nitrate }+ \text { nitrite }+ \\
\text { ammonia }+ \text { organic-N), water, filtered, } \\
\text { analytically determined, milligrams } \\
\text { per liter }\end{array}$ & .14 & .13 & .12 & .12 & $<.05$ & .12 \\
\hline P62855 & $\begin{array}{l}\text { Total nitrogen (nitrate }+ \text { nitrite }+ \\
\text { ammonia }+ \text { organic-N), water, } \\
\text { unfiltered, analytically determined, } \\
\text { milligrams per liter }\end{array}$ & .17 & .2 & .14 & .13 & $<.05$ & .15 \\
\hline P31616 & $\begin{array}{l}\text { Fecal-coliform bacteria, M-FC MF ( } 0.45 \\
\text { micrometer) method, water, colony- } \\
\text { forming units per } 100 \text { milliliters }\end{array}$ & - & - & $<1$ & - & - & 1 \\
\hline P70953 & $\begin{array}{l}\text { Chlorophyll } a \text {, phytoplankton, } \\
\text { chromatographic-fluorometric } \\
\text { method, } \mu \mathrm{g} / \mathrm{L}\end{array}$ & - & - & e. 4 & - & $<.01$ & e 1.2 \\
\hline P62360 & Pheophytin $a$, phytoplankton, $\mu \mathrm{g} / \mathrm{L}$ & - & - & e. 1 & - & $<.01$ & e. 5 \\
\hline
\end{tabular}


Appendix D2. Concentrations of constituents in field blank samples and replicate samples along with the corresponding environmental concentrations from Lake Tapps study sites, July-December 2010.—Continued

[All values except turbidity and fecal-coliform bacteria referenced to laboratory long-term method detection levels A bbreviations: nm, nanometer; <, less than; e, estimated; $\mu \mathrm{g} / \mathrm{L}$, microgram per liter; -, no quality-control sample; NTRU, nephelometric turbidity ratio units]

\begin{tabular}{|c|c|c|c|c|c|c|c|}
\hline \multirow{4}{*}{$\begin{array}{l}\text { STAID } \\
\text { SNAME } \\
\text { DATES } \\
\text { TIMES }\end{array}$} & \multirow{4}{*}{$\begin{array}{l}\text { Station number } \\
\text { Station name } \\
\text { Date } \\
\text { Sample start time }\end{array}$} & \multicolumn{6}{|c|}{471423122115001} \\
\hline & & \multicolumn{6}{|c|}{ EPILIMNION-Lake Outlet (map No. L8) } \\
\hline & & \multicolumn{2}{|c|}{20100707} & \multicolumn{2}{|c|}{20100721} & \multicolumn{2}{|c|}{20100804} \\
\hline & & 1000 & 1001 & 0940 & 0941 & 1018 & 1010 \\
\hline $\begin{array}{l}\text { Parameter } \\
\text { code }\end{array}$ & Parameter name & $\begin{array}{l}\text { Sample } \\
\text { concen- } \\
\text { tration }\end{array}$ & $\begin{array}{c}\text { Replicate } \\
\text { concen- } \\
\text { tration }\end{array}$ & $\begin{array}{l}\text { Sample } \\
\text { concen- } \\
\text { tration }\end{array}$ & $\begin{array}{c}\text { Replicate } \\
\text { concen- } \\
\text { tration }\end{array}$ & $\begin{array}{l}\text { Blank } \\
\text { concen- } \\
\text { tration }\end{array}$ & $\begin{array}{l}\text { Sample } \\
\text { concen- } \\
\text { tration }\end{array}$ \\
\hline P63676 & $\begin{array}{l}\text { Turbidity, water, unfiltered, broad band } \\
\text { light source }(400-680 \mathrm{~nm}) \text {, detectors } \\
\text { at multiple angles including } 90+/-30 \\
\text { degrees, ratiometric correction, NTRU }\end{array}$ & 0.9 & 0.9 & 0.6 & - & 0.2 & 0.6 \\
\hline P00530 & $\begin{array}{l}\text { Suspended solids, water, unfiltered, } \\
\text { milligrams per liter }\end{array}$ & e 2.4 & e 1.6 & $<1.1$ & - & $<1.1$ & $<1.1$ \\
\hline P00608 & $\begin{array}{l}\text { Ammonia, water, filtered, milligrams per } \\
\text { liter as nitrogen }\end{array}$ & $<.010$ & $<.010$ & $<.010$ & - & $<.010$ & $<.010$ \\
\hline P00631 & $\begin{array}{l}\text { Nitrite plus nitrate, water, filtered, } \\
\text { milligrams per liter as nitrogen }\end{array}$ & $<.008$ & e. 008 & $<.008$ & - & $<.008$ & $<.008$ \\
\hline P00613 & $\begin{array}{l}\text { Nitrite, water, filtered, milligrams per liter as } \\
\text { nitrogen }\end{array}$ & $<.001$ & $<.001$ & $<.001$ & - & $<.001$ & $<.001$ \\
\hline P00671 & $\begin{array}{l}\text { Orthophosphate, water, filtered, milligrams } \\
\text { per liter as phosphorus }\end{array}$ & $<.004$ & $<.004$ & e. .004 & - & $<.004$ & $<.004$ \\
\hline P00666 & $\begin{array}{l}\text { Phosphorus, water, filtered, milligrams per } \\
\text { liter as phosphorus }\end{array}$ & e. 005 & e. 004 & $<.003$ & - & $<.003$ & e. 005 \\
\hline P00665 & $\begin{array}{l}\text { Phosphorus, water, unfiltered, milligrams per } \\
\text { liter as phosphorus }\end{array}$ & .009 & .01 & $<.004$ & - & $<.004$ & e. 005 \\
\hline P62854 & $\begin{array}{l}\text { Total nitrogen (nitrate }+ \text { nitrite }+ \text { ammonia } \\
\quad+\text { organic-N), water, filtered, analytically } \\
\text { determined, milligrams per liter }\end{array}$ & e.09 & .11 & .12 & - & $<.05$ & e. 07 \\
\hline P62855 & $\begin{array}{l}\text { Total nitrogen (nitrate }+ \text { nitrite }+ \text { ammonia }+ \\
\text { organic-N), water, unfiltered, analytically } \\
\text { determined, milligrams per liter }\end{array}$ & .27 & .15 & .15 & - & $<.05$ & .15 \\
\hline P31616 & $\begin{array}{l}\text { Fecal-coliform bacteria, M-FC MF ( } 0.45 \\
\text { micrometer) method, water, colony- } \\
\text { forming units per } 100 \text { milliliters }\end{array}$ & 2 & 4 & 7 & - & - & 3 \\
\hline P70953 & $\begin{array}{l}\text { Chlorophyll } a \text {, phytoplankton, } \\
\text { chromatographic-fluorometric method, } \\
\mu \mathrm{g} / \mathrm{L}\end{array}$ & e. 8 & - & e.9 & e.9 & - & e 1.0 \\
\hline P62360 & Pheophytin $a$, phytoplankton, $\mu g / L$ & e. 4 & - & e. 4 & e. 4 & - & e.5 \\
\hline
\end{tabular}


Appendix D2. Concentrations of constituents in field blank samples and replicate samples along with the corresponding environmental concentrations from Lake Tapps study sites, July-December 2010.—Continued

[All values except turbidity and fecal-coliform bacteria referenced to laboratory long-term method detection levels A bbreviations: nm, nanometer; <, less than; e, estimated; $\mu \mathrm{g} / \mathrm{L}$, microgram per liter; -, no quality-control sample; NTRU, nephelometric turbidity ratio units]

\begin{tabular}{|c|c|c|c|c|c|c|c|}
\hline \multirow{4}{*}{$\begin{array}{c}\text { STAID } \\
\text { SNAME } \\
\text { DATES } \\
\text { TIMES }\end{array}$} & \multirow{4}{*}{$\begin{array}{l}\text { Station number } \\
\text { Station name } \\
\text { Date } \\
\text { Sample start time }\end{array}$} & \multicolumn{6}{|c|}{471423122115001} \\
\hline & & \multicolumn{6}{|c|}{ EPILIMNION-Lake Outlet (map No. L8) } \\
\hline & & \multicolumn{2}{|c|}{20100908} & \multicolumn{2}{|c|}{20101013} & \multicolumn{2}{|c|}{20101208} \\
\hline & & 0930 & 0931 & 0958 & 0950 & 0830 & 0831 \\
\hline $\begin{array}{l}\text { Parameter } \\
\text { code }\end{array}$ & Parameter name & $\begin{array}{l}\text { Sample } \\
\text { concen- } \\
\text { tration }\end{array}$ & $\begin{array}{l}\text { Replicate } \\
\text { concen- } \\
\text { tration }\end{array}$ & $\begin{array}{l}\text { Blank } \\
\text { concen- } \\
\text { tration }\end{array}$ & $\begin{array}{c}\text { Sample } \\
\text { concen- } \\
\text { tration }\end{array}$ & $\begin{array}{l}\text { Sample } \\
\text { concen- } \\
\text { tration }\end{array}$ & $\begin{array}{l}\text { Replicate } \\
\text { concen- } \\
\text { tration }\end{array}$ \\
\hline P63676 & $\begin{array}{l}\text { Turbidity, water, unfiltered, broad band light } \\
\text { source (400-680 nm), detectors at multiple } \\
\text { angles including } 90+/-30 \text { degrees, ratiometric } \\
\text { correction, NTRU }\end{array}$ & 0.7 & - & 0.1 & 0.6 & 2.3 & 2.4 \\
\hline P00530 & $\begin{array}{l}\text { Suspended solids, water, unfiltered, milligrams } \\
\text { per liter }\end{array}$ & $<1.1$ & - & $<1.1$ & $<1.1$ & $<1.1$ & $<1.1$ \\
\hline P00608 & $\begin{array}{l}\text { Ammonia, water, filtered, milligrams per liter as } \\
\text { nitrogen }\end{array}$ & .023 & - & .01 & .011 & .038 & .05 \\
\hline P00631 & $\begin{array}{l}\text { Nitrite plus nitrate, water, filtered, milligrams per } \\
\text { liter as nitrogen }\end{array}$ & $<.008$ & - & $<.008$ & $<.008$ & .029 & .035 \\
\hline P00613 & $\begin{array}{l}\text { Nitrite, water, filtered, milligrams per liter as } \\
\text { nitrogen }\end{array}$ & $<.001$ & - & $<.001$ & $<.001$ & .001 & .001 \\
\hline P00671 & $\begin{array}{l}\text { Orthophosphate, water, filtered, milligrams per } \\
\text { liter as phosphorus }\end{array}$ & e. 005 & - & $<.004$ & $<.004$ & .004 & .004 \\
\hline P00666 & $\begin{array}{l}\text { Phosphorus, water, filtered, milligrams per liter } \\
\text { as phosphorus }\end{array}$ & $<.003$ & - & $<.003$ & $<.003$ & $<.003$ & $<.003$ \\
\hline P00665 & $\begin{array}{l}\text { Phosphorus, water, unfiltered, milligrams per liter } \\
\text { as phosphorus }\end{array}$ & e.004 & - & $<.004$ & $<.004$ & .006 & .008 \\
\hline P62854 & $\begin{array}{l}\text { Total nitrogen (nitrate }+ \text { nitrite }+ \text { ammonia } \\
+ \text { organic-N), water, filtered, analytically } \\
\text { determined, milligrams per liter }\end{array}$ & .14 & - & $<.05$ & - & - & - \\
\hline P62855 & $\begin{array}{l}\text { Total nitrogen (nitrate }+ \text { nitrite }+ \text { ammonia }+ \\
\text { organic-N), water, unfiltered, analytically } \\
\text { determined, milligrams per liter }\end{array}$ & .15 & - & $<.05$ & .12 & .16 & .2 \\
\hline P31616 & $\begin{array}{l}\text { Fecal-coliform bacteria, M-FC MF ( } 0.45 \\
\text { micrometer) method, water, colony-forming } \\
\text { units per } 100 \text { milliliters }\end{array}$ & 54 & 77 & - & 1 & 15 & - \\
\hline P70953 & $\begin{array}{l}\text { Chlorophyll } a \text {, phytoplankton, chromatographic- } \\
\text { fluorometric method, } \mu \mathrm{g} / \mathrm{L}\end{array}$ & e. 7 & - & $<.01$ & e. 6 & e 1.1 & - \\
\hline P62360 & Pheophytin $a$, phytoplankton, $\mu \mathrm{g} / \mathrm{L}$ & e. 4 & - & $<.01$ & e. 3 & e. 5 & - \\
\hline
\end{tabular}


Appendix D2. Concentrations of constituents in field blank samples and replicate samples along with the corresponding environmental concentrations from Lake Tapps study sites, July-December 2010.—Continued

[All values except turbidity and fecal-coliform bacteria referenced to laboratory long-term method detection levels A bbreviations: nm, nanometer; <, less than; e, estimated; $\mu \mathrm{g} / \mathrm{L}$, microgram per liter; -, no quality-control sample; NTRU, nephelometric turbidity ratio units]

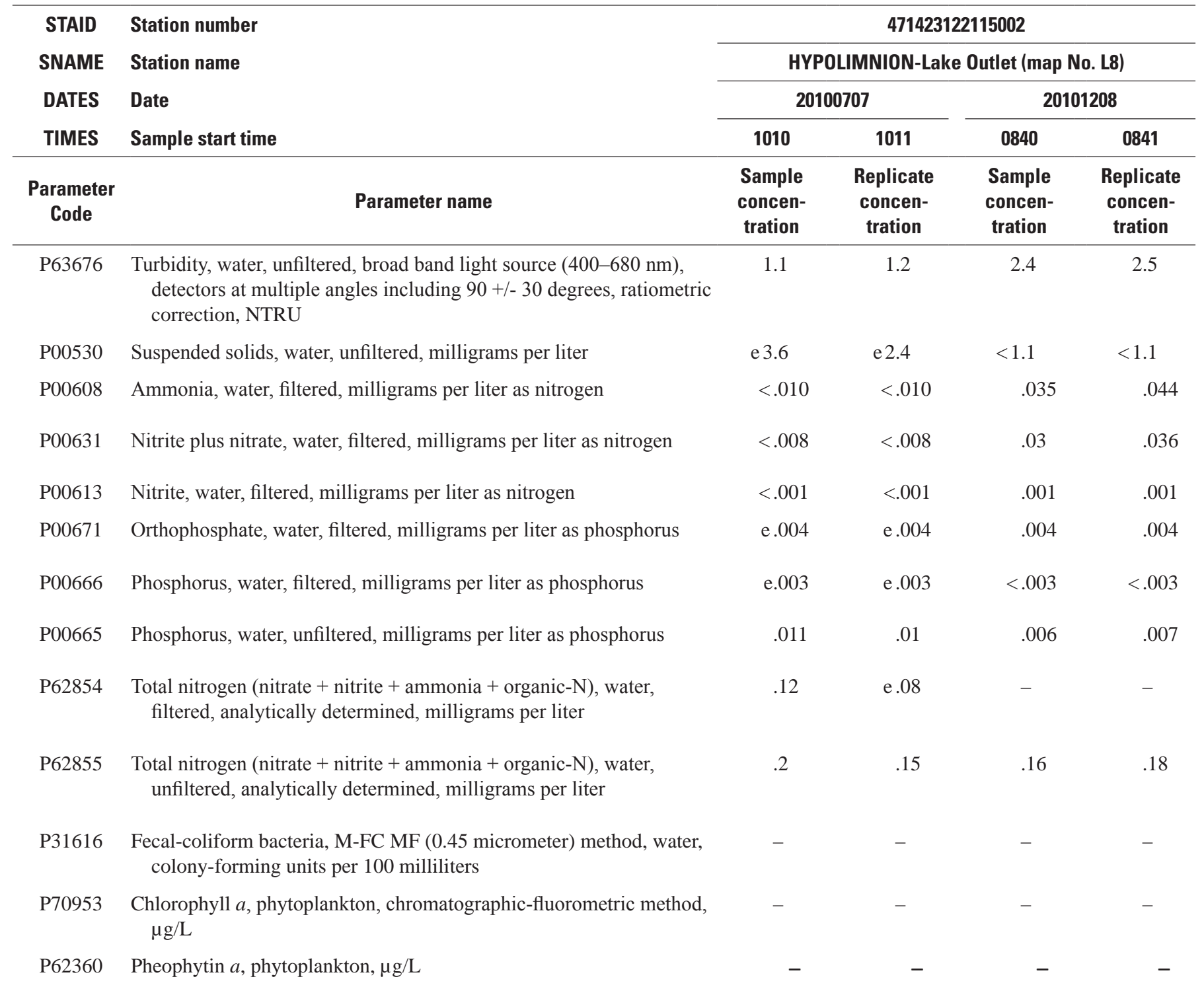


Appendix D2. Concentrations of constituents in field blank samples and replicate samples along with the corresponding environmental concentrations from Lake Tapps study sites, July-December 2010.—Continued

[All values except turbidity and fecal-coliform bacteria referenced to laboratory long-term method detection levels Abbreviations: nm, nanometer; <, less than; e, estimated; $\mu \mathrm{g} / \mathrm{L}$, microgram per liter; -, no quality-control sample; NTRU, nephelometric turbidity ratio units]

\begin{tabular}{|c|c|c|c|c|c|c|c|}
\hline \multirow{4}{*}{$\begin{array}{l}\text { STAID } \\
\text { SNAME } \\
\text { DATES } \\
\text { TIMES }\end{array}$} & \multirow{4}{*}{$\begin{array}{l}\text { Station number } \\
\text { Station name } \\
\text { Date } \\
\text { Sample start time }\end{array}$} & \multicolumn{4}{|c|}{471456122110801} & \multirow{2}{*}{\multicolumn{2}{|c|}{$\begin{array}{c}471456122110801 \\
\text { EPILIMNION-Dike 2B (L9) }\end{array}$}} \\
\hline & & \multicolumn{4}{|c|}{ EPILIMNION-Dike 2B (map No. L9) } & & \\
\hline & & \multicolumn{2}{|c|}{20100721} & \multicolumn{2}{|c|}{20100818} & \multicolumn{2}{|c|}{20101117} \\
\hline & & 1058 & 1050 & 1028 & 1020 & 0938 & 0930 \\
\hline $\begin{array}{l}\text { Parameter } \\
\text { code }\end{array}$ & Parameter name & $\begin{array}{l}\text { Blank } \\
\text { concen- } \\
\text { tration }\end{array}$ & $\begin{array}{l}\text { Sample } \\
\text { concen- } \\
\text { tration }\end{array}$ & $\begin{array}{l}\text { Blank } \\
\text { concen- } \\
\text { tration }\end{array}$ & $\begin{array}{l}\text { Sample } \\
\text { concen- } \\
\text { tration }\end{array}$ & $\begin{array}{l}\text { Blank } \\
\text { concen- } \\
\text { tration }\end{array}$ & $\begin{array}{l}\text { Sample } \\
\text { concen- } \\
\text { tration }\end{array}$ \\
\hline P63676 & $\begin{array}{l}\text { Turbidity, water, unfiltered, broad band } \\
\text { light source (400-680 nm), detectors } \\
\text { at multiple angles including } 90+/-30 \\
\text { degrees, ratiometric correction, NTRU }\end{array}$ & 0.1 & 0.7 & 0.2 & 0.6 & 0.1 & 2.5 \\
\hline P00530 & $\begin{array}{l}\text { Suspended solids, water, unfiltered, } \\
\text { milligrams per liter }\end{array}$ & $<1.1$ & e 1.2 & $<1.1$ & $<1.1$ & $<1.1$ & $<1.1$ \\
\hline P00631 & $\begin{array}{l}\text { Nitrite plus nitrate, water, filtered, } \\
\text { milligrams per liter as nitrogen }\end{array}$ & $<.008$ & $<.008$ & $<.008$ & $<.008$ & $<.008$ & .015 \\
\hline P00613 & $\begin{array}{l}\text { Nitrite, water, filtered, milligrams per liter } \\
\text { as nitrogen }\end{array}$ & $<.001$ & $<.001$ & $<.001$ & $<.001$ & $<.001$ & .002 \\
\hline P00671 & $\begin{array}{l}\text { Orthophosphate, water, filtered, } \\
\text { milligrams per liter as phosphorus }\end{array}$ & $<.004$ & e.005 & $<.004$ & e.004 & $<.004$ & $<.004$ \\
\hline P00666 & $\begin{array}{l}\text { Phosphorus, water, filtered, milligrams } \\
\text { per liter as phosphorus }\end{array}$ & $<.003$ & e .003 & $<.003$ & $<.003$ & $<.003$ & $<.003$ \\
\hline P00665 & $\begin{array}{l}\text { Phosphorus, water, unfiltered, milligrams } \\
\text { per liter as phosphorus }\end{array}$ & $<.004$ & e. 005 & $<.004$ & e.005 & $<.004$ & $<.004$ \\
\hline P31616 & $\begin{array}{l}\text { Fecal-coliform bacteria, M-FC MF (0.45 } \\
\text { micrometer) method, water, colony- } \\
\text { forming units per } 100 \text { milliliters }\end{array}$ & - & $<1$ & - & 15 & - & 1 \\
\hline P70953 & $\begin{array}{l}\text { Chlorophyll } a \text {, phytoplankton, } \\
\text { chromatographic-fluorometric method, } \\
\mu \mathrm{g} / \mathrm{L}\end{array}$ & - & e 1.0 & - & e. 6 & $<.1$ & e. 7 \\
\hline P62360 & Pheophytin $a$, phytoplankton, $\mu \mathrm{g} / \mathrm{L}$ & - & e. 5 & - & e.3 & $<.1$ & e. 3 \\
\hline
\end{tabular}


Appendix D2. Concentrations of constituents in field blank samples and replicate samples along with the corresponding environmental concentrations from Lake Tapps study sites, July-December 2010.—Continued

[All values except turbidity and fecal-coliform bacteria referenced to laboratory long-term method detection levels Abbreviations: nm, nanometer; <, less than; e, estimated; $\mu \mathrm{g} / \mathrm{L}$, microgram per liter; -, no quality-control sample; NTRU, nephelometric turbidity ratio units]

\begin{tabular}{|c|c|c|c|}
\hline STAID & Station number & \multicolumn{2}{|c|}{471456122110802} \\
\hline SNAME & Station name & \multicolumn{2}{|c|}{ HYPOLIMNION-Dike 2B (map No. L9) } \\
\hline DATES & Date & \multicolumn{2}{|c|}{20100922} \\
\hline TIMES & Sample start time & 1100 & 1101 \\
\hline $\begin{array}{l}\text { Parameter } \\
\text { code }\end{array}$ & Parameter name & $\begin{array}{l}\text { Sample } \\
\text { concen- } \\
\text { tration }\end{array}$ & $\begin{array}{l}\text { Replicate } \\
\text { concen- } \\
\text { tration }\end{array}$ \\
\hline P63676 & $\begin{array}{l}\text { Turbidity, water, unfiltered, broad band light source }(400-680 \mathrm{~nm}) \text {, detectors at } \\
\text { multiple angles including } 90+/-30 \text { degrees, ratiometric correction, NTRU }\end{array}$ & 0.7 & 0.7 \\
\hline P00530 & Suspended solids, water, unfiltered, milligrams per liter & $<1.1$ & $<1.1$ \\
\hline P00608 & Ammonia, water, filtered, milligrams per liter as nitrogen & $<.010$ & $<.010$ \\
\hline P00631 & Nitrite plus nitrate, water, filtered, milligrams per liter as nitrogen & $<.008$ & $<.008$ \\
\hline P00613 & Nitrite, water, filtered, milligrams per liter as nitrogen & $<.001$ & $<.001$ \\
\hline P00671 & Orthophosphate, water, filtered, milligrams per liter as phosphorus & $<.004$ & $<.004$ \\
\hline P00666 & Phosphorus, water, filtered, milligrams per liter as phosphorus & $<.003$ & $<.003$ \\
\hline P00665 & Phosphorus, water, unfiltered, milligrams per liter as phosphorus & e. 004 & e. 004 \\
\hline P62854 & $\begin{array}{l}\text { Total nitrogen (nitrate }+ \text { nitrite }+ \text { ammonia }+ \text { organic-N), water, filtered, } \\
\text { analytically determined, milligrams per liter }\end{array}$ & .11 & .1 \\
\hline P62855 & $\begin{array}{l}\text { Total nitrogen (nitrate }+ \text { nitrite }+ \text { ammonia }+ \text { organic-N), water, unfiltered, } \\
\text { analytically determined, milligrams per liter }\end{array}$ & .11 & .1 \\
\hline P31616 & $\begin{array}{l}\text { Fecal-coliform bacteria, M-FC MF ( } 0.45 \text { micrometer) method, water, colony- } \\
\text { forming units per } 100 \text { milliliters }\end{array}$ & - & - \\
\hline P70953 & Chlorophyll $a$, phytoplankton, chromatographic-fluorometric method, $\mu \mathrm{g} / \mathrm{L}$ & - & - \\
\hline P62360 & Pheophytin $a$, phytoplankton, $\mu \mathrm{g} / \mathrm{L}$ & - & - \\
\hline
\end{tabular}


Appendix D3. Concentrations of organic compounds in field blank samples and matrix-spike samples along with the corresponding environmental concentrations from the Lake Outlet site (map No. L8) on Lake Tapps, September 22, 2010.

[All mesurements in micrograms per liter $(\mu \mathrm{g} / \mathrm{L})$. A bbreviatons: e, estimated; <, less than; -, no quality-control sample]

\begin{tabular}{|c|c|c|c|c|c|}
\hline STAID & Station number & \multicolumn{4}{|c|}{471423122115001} \\
\hline SNAME & Station name & \multicolumn{4}{|c|}{ EPILIMNION } \\
\hline DATES & Date & \multicolumn{4}{|c|}{20100922} \\
\hline TIMES & Sample start time & 0948 & 0940 & 0942 & 0943 \\
\hline $\begin{array}{l}\text { Parameter } \\
\text { code }\end{array}$ & Parameter name & $\begin{array}{l}\text { Blank } \\
\text { concen- } \\
\text { tration }\end{array}$ & $\begin{array}{c}\text { Sample } \\
\text { concen- } \\
\text { tration }\end{array}$ & $\begin{array}{c}\text { Matrix spike } \\
\text { concen- } \\
\text { tration, } \\
\text { schedule } \\
2080\end{array}$ & $\begin{array}{c}\text { Matrix spike } \\
\text { concen- } \\
\text { tration, } \\
\text { schedule } \\
1433\end{array}$ \\
\hline P62030 & 1,7-Dimethylxanthine, water, filtered, recoverable & $<0.10$ & $<0.10$ & e 0.220 & \\
\hline P62000 & Acetaminophen, water, filtered, recoverable & $<.12$ & $<.12$ & .244 & - \\
\hline P62020 & Albuterol, water, filtered, recoverable & $<.08$ & $<.08$ & .220 & - \\
\hline P50305 & Caffeine, water, filtered, recoverable & $<.06$ & $<.08$ & .362 & - \\
\hline P62793 & Carbamazepine, water, filtered, recoverable & $<.06$ & $<.16$ & .186 & - \\
\hline P62003 & Codeine, water, filtered, recoverable & $<.046$ & $<.32$ & .246 & - \\
\hline P62005 & Cotinine, water, filtered, recoverable & $<.038$ & $<.038$ & .189 & - \\
\hline P62004 & Dehydronifedipine, water, filtered, recoverable & $<.08$ & $<.08$ & .278 & - \\
\hline P62008 & Diltiazem, water, filtered, recoverable & $<.06$ & $<.04$ & e. 221 & - \\
\hline P62796 & Diphenhydramine, water, filtered, recoverable & $<.036$ & $<.08$ & .193 & - \\
\hline P62021 & Sulfamethoxazole, water, filtered, recoverable & $<.16$ & $<.16$ & e.048 & - \\
\hline P62801 & Thiabendazole, water, filtered, recoverable & $<.06$ & $<.06$ & .148 & - \\
\hline P62023 & Trimethoprim, water, filtered, recoverable & $<.034$ & $<.034$ & .222 & - \\
\hline P62024 & Warfarin, water, filtered, recoverable & $<.08$ & $<.08$ & e. 204 & - \\
\hline P34572 & 1,4-Dichlorobenzene, water, filtered, recoverable & $<.040$ & $<.040$ & - & 0.52 \\
\hline P62054 & 1-Methylnaphthalene, water, filtered, recoverable & $<.022$ & $<.022$ & - & .29 \\
\hline P62055 & 2,6-Dimethylnaphthalene, water, filtered, recoverable & $<.06$ & $<.06$ & - & .26 \\
\hline P62056 & 2-Methylnaphthalene, water, filtered, recoverable & $<.036$ & $<.036$ & - & .27 \\
\hline P62057 & 3-beta-Coprostanol, water, filtered, recoverable & $<1.8$ & $<1.8$ & - & e2.00 \\
\hline P62058 & 3-Methyl-1H-indole, water, filtered, recoverable & $<.036$ & $<.036$ & - & .34 \\
\hline P62059 & 3-tert-Butyl-4-hydroxyanisole, water, filtered, recoverable & & $<8$ & - & e.092 \\
\hline P62060 & 4-Cumylphenol, water, filtered, recoverable & $<.06$ & $<.06$ & - & .35 \\
\hline P62061 & 4-n-Octylphenol, water, filtered, recoverable & $<.16$ & $<.16$ & - & e.100 \\
\hline P62085 & 4-Nonylphenol (sum of all isomers), water, filtered, recoverable & $<2$ & $<2$ & - & e 2.00 \\
\hline P62083 & $\begin{array}{l}\text { 4-Nonylphenol diethoxylate (sum of all isomers), water, filtered, } \\
\text { recoverable }\end{array}$ & $<5.0$ & $<5.0$ & - & e 4.50 \\
\hline P61705 & 4-tert-Octylphenol diethoxylate, water, filtered, recoverable & $<1.0$ & $<1.0$ & - & e.370 \\
\hline P61706 & 4-tert-Octylphenol monoethoxylate, water, filtered, recoverable & $<1.0$ & $<1.0$ & - & e 1.10 \\
\hline P62062 & 4-tert-Octylphenol, water, filtered, recoverable & $<.14$ & $<.14$ & - & e.150 \\
\hline P62063 & 5-Methyl-1H-benzotriazole, water, filtered, recoverable & $<1.2$ & $<1.2$ & - & 1.7 \\
\hline P62066 & 9,10-Anthraquinone, water, filtered, recoverable & $<.16$ & $<.16$ & - & e. 420 \\
\hline P62064 & Acetophenone, water, filtered, recoverable & $<.4$ & $<.4$ & - & .9 \\
\hline P62065 & $\begin{array}{l}\text { Acetyl hexamethyl tetrahydro naphthalene, water, filtered, } \\
\text { recoverable }\end{array}$ & $<.028$ & $<.028$ & - & .39 \\
\hline P34221 & Anthracene, water, filtered, recoverable & $<.028$ & $<.028$ & - & .17 \\
\hline P34248 & Benzo[a]pyrene, water, filtered, recoverable & $<.050$ & $<.050$ & - & .16 \\
\hline P62067 & Benzophenone, water, filtered, recoverable & .046 & $<.08$ & - & .88 \\
\hline P62068 & beta-Sitosterol, water, filtered, recoverable & $<4$ & $<4$ & - & e 3.80 \\
\hline P62086 & beta-Stigmastanol, water, filtered, recoverable & $<2.6$ & $<2.6$ & - & e 1.10 \\
\hline P04029 & Bromacil, water, filtered, recoverable & $<.36$ & $<.06$ & - & 1.6 \\
\hline P62070 & Camphor, water, filtered, recoverable & $<.044$ & $<.044$ & - & .8 \\
\hline
\end{tabular}


Appendix D3. Concentrations of organic compounds in field blank samples and matrix-spike samples along with the corresponding environmental concentrations from the Lake Outlet site (map No. L8) on Lake Tapps, September 22, 2010. - Continued

[All mesurements in micrograms per liter ( $\mu \mathrm{g} / \mathrm{L})$. Abbreviatons: e, estimated; <, less than; -, no quality-control sample]

\begin{tabular}{|c|c|c|c|c|c|}
\hline STAID & Station number & \multicolumn{4}{|c|}{471423122115001} \\
\hline SNAME & Station name & \multicolumn{4}{|c|}{ EPILIMNION } \\
\hline DATES & Date & \multicolumn{4}{|c|}{20100922} \\
\hline TIMES & Sample start time & 0948 & 0940 & 0942 & 0943 \\
\hline $\begin{array}{l}\text { Parameter } \\
\text { code }\end{array}$ & Parameter name & $\begin{array}{c}\text { Blank } \\
\text { concen- } \\
\text { tration }\end{array}$ & $\begin{array}{c}\text { Sample } \\
\text { concen- } \\
\text { tration }\end{array}$ & $\begin{array}{l}\text { Matrix spike } \\
\text { concen- } \\
\text { tration, } \\
\text { schedule } \\
2080\end{array}$ & $\begin{array}{c}\text { Matrix spike } \\
\text { concen- } \\
\text { tration, } \\
\text { schedule } \\
1433\end{array}$ \\
\hline P82680 & Carbaryl, water, filtered ( 0.7 micron glass fiber filter), recoverable & $<0.38$ & $<0.06$ & - & e 0.550 \\
\hline P62071 & Carbazole, water, filtered, recoverable & $<.030$ & $<.030$ & - & .22 \\
\hline Р38933 & Chlorpyrifos, water, filtered, recoverable & $<.16$ & $<.010$ & - & 2.8 \\
\hline P62072 & Cholesterol, water, filtered, recoverable & $<2$ & $<2$ & - & e2.00 \\
\hline P62082 & DEET, water, filtered, recoverable & $<.06$ & e. 008 & - & .42 \\
\hline P39572 & Diazinon, water, filtered, recoverable & $<.16$ & $<.005$ & - & 1.9 \\
\hline P62073 & $d$-Limonene, water, filtered, recoverable & $<.08$ & $<.08$ & - & .52 \\
\hline P34377 & Fluoranthene, water, filtered, recoverable & $<.024$ & $<.024$ & - & .2 \\
\hline P62075 & $\begin{array}{l}\text { Hexahydrohexamethyl cyclopentabenzopyran, water, filtered, } \\
\text { recoverable }\end{array}$ & $<.052$ & $<.052$ & - & .38 \\
\hline P62076 & Indole, water, filtered, recoverable & $<.08$ & $<.08$ & - & .096 \\
\hline P62077 & Isoborneol, water, filtered, recoverable & $<.18$ & $<.18$ & - & .76 \\
\hline P34409 & Isophorone, water, filtered, recoverable & e. 033 & $<.08$ & - & .37 \\
\hline P62078 & Isopropylbenzene, water, filtered, recoverable & $<.30$ & $<.30$ & - & .23 \\
\hline P62079 & Isoquinoline, water, filtered, recoverable & $<.046$ & $<.20$ & - & $<.046$ \\
\hline P62080 & Menthol, water, filtered, recoverable & $<.32$ & $<.32$ & - & 3.1 \\
\hline P50359 & Metalaxyl, water, filtered, recoverable & $<.12$ & $<.04$ & - & 1.6 \\
\hline P62081 & Methyl salicylate, water, filtered, recoverable & $<.044$ & $<.044$ & - & .83 \\
\hline P39415 & Metolachlor, water, filtered, recoverable & $<.08$ & $<.014$ & - & .38 \\
\hline P34443 & Naphthalene, water, filtered, recoverable & $<.040$ & $<.040$ & - & .16 \\
\hline P62084 & $p$-Cresol, water, filtered, recoverable & $<.08$ & $<.40$ & - & .71 \\
\hline P34462 & Phenanthrene, water, filtered, recoverable & $<.032$ & $<.032$ & - & .18 \\
\hline P34466 & Phenol, water, filtered, recoverable & .14 & $<.16$ & - & .81 \\
\hline P04037 & Prometon, water, filtered, recoverable & $<.12$ & .013 & - & e 1.60 \\
\hline P34470 & Pyrene, water, filtered, recoverable & $<.042$ & $<.042$ & - & .2 \\
\hline P34476 & Tetrachloroethene, water, filtered, recoverable & $<.12$ & $<.12$ & - & e. 320 \\
\hline P34288 & Tribromomethane, water, filtered, recoverable & $<.10$ & $<.10$ & - & .99 \\
\hline P62089 & Tributyl phosphate, water, filtered, recoverable & $<.16$ & $<.16$ & - & .36 \\
\hline P62090 & Triclosan, water, filtered, recoverable & $<.20$ & $<.20$ & - & 2.8 \\
\hline P62091 & Triethyl citrate, water, filtered, recoverable & $<.38$ & $<.38$ & - & .4 \\
\hline P62092 & Triphenyl phosphate, water, filtered, recoverable & $<.12$ & $<.12$ & - & .78 \\
\hline P62093 & Tris(2-butoxyethyl) phosphate, water, filtered, recoverable & $<.8$ & $<.8$ & - & e6.30 \\
\hline P62087 & Tris(2-chloroethyl) phosphate, water, filtered, recoverable & $<.10$ & $<.10$ & - & 1.5 \\
\hline P62088 & Tris(dichloroisopropyl) phosphate, water, filtered, recoverable & $<.16$ & $<.16$ & - & 3.4 \\
\hline
\end{tabular}




\section{Appendix E. Seven-Day Average of Daily Maximum Temperatures on the White River at Headworks, White River at R Street, and Lake Tapps Diversion (Tailrace), Washington, May-December 2010}

[7-day average of daily maximum temperatures, degrees Celsius. A bbreviations: -, not available or not applicable]

\begin{tabular}{|c|c|c|c|c|c|c|c|}
\hline Dates & Headworks & R-Street & Tailrace & Dates & Headworks & R-Street & Tailrace \\
\hline \multicolumn{4}{|c|}{ May } & \multicolumn{4}{|c|}{ July-Continued } \\
\hline 30 & - & 10.1 & - & 15 & 14.7 & 15.1 & 16.8 \\
\hline 31 & 9.3 & 10.1 & - & 16 & 14.5 & 14.9 & 16.6 \\
\hline \multicolumn{4}{|c|}{ June } & 17 & 14.8 & 15.0 & 16.5 \\
\hline 1 & 9.4 & 10.3 & 13.7 & 18 & 15.0 & 15.3 & 16.2 \\
\hline 2 & 9.9 & 10.7 & 13.6 & 19 & 15.0 & 15.1 & 16.0 \\
\hline 3 & 10.2 & 11.0 & 13.5 & 20 & 15.1 & 15.2 & 15.8 \\
\hline 4 & 10.2 & 11.0 & $\begin{array}{l}13.0 \\
13.2\end{array}$ & 21 & 15.3 & 15.7 & 15.9 \\
\hline 5 & 10.4 & 11.2 & $\begin{array}{l}13.2 \\
12.9\end{array}$ & 22 & 15.5 & 16.2 & 16.0 \\
\hline 6 & 10.5 & 11.3 & $\begin{array}{l}12.9 \\
12.8\end{array}$ & 23 & 15.7 & 16.6 & 16.2 \\
\hline 7 & 10.5 & 11.4 & $\begin{array}{l}12.8 \\
12.7\end{array}$ & 24 & 15.9 & 17.1 & 16.3 \\
\hline 8 & 10.7 & 11.5 & $\begin{array}{l}12.7 \\
12.7\end{array}$ & 25 & 16.0 & 17.1 & 16.3 \\
\hline 9 & 10.9 & - & $\begin{array}{l}12.7 \\
12.7\end{array}$ & 26 & 16.0 & 17.2 & 16.2 \\
\hline 10 & 11.1 & - & $\begin{array}{l}12.7 \\
128\end{array}$ & 27 & 16.1 & 17.3 & 16.0 \\
\hline 11 & 11.3 & - & $\begin{array}{l}12.8 \\
12.7\end{array}$ & 28 & 15.9 & 16.9 & 15.8 \\
\hline 12 & 11.2 & - & $\begin{array}{l}12.7 \\
12.7\end{array}$ & 29 & 15.8 & 16.7 & 15.5 \\
\hline 13 & 11.0 & - & $\begin{array}{l}12.7 \\
12.7\end{array}$ & 30 & 15.7 & 16.3 & 15.2 \\
\hline 14 & 10.8 & - & $\begin{array}{l}12.7 \\
12.8\end{array}$ & 31 & 15.7 & 16.1 & 15.0 \\
\hline 15 & 11.0 & - & $\begin{array}{l}12.0 \\
13.3\end{array}$ & \multicolumn{4}{|c|}{ August } \\
\hline 16 & 10.7 & - & 13.5 & 1 & 15.7 & 16.4 & 15.0 \\
\hline 17 & 10.2 & - & 13.4 & 2 & 15.8 & 16.7 & 15.3 \\
\hline 18 & 10.2 & - & 13.7 & 3 & 15.9 & 16.7 & 15.5 \\
\hline 19 & 10.6 & - & 14.5 & 4 & 15.9 & 16.8 & 15.8 \\
\hline 20 & 11.3 & - & 15.2 & 5 & 15.7 & 16.6 & 15.6 \\
\hline 21 & 12.0 & - & 15.8 & 6 & 15.6 & 16.5 & 15.5 \\
\hline 22 & 12.2 & - & 16.0 & 7 & 15.4 & 16.4 & 15.4 \\
\hline 23 & 12.6 & - & 16.5 & 8 & 15.3 & 16.3 & 15.4 \\
\hline 24 & 13.3 & - & 17.1 & 9 & 15.3 & 16.2 & 15.3 \\
\hline 25 & 13.6 & - & 17.1 & 10 & 15.3 & 16.6 & 15.3 \\
\hline 26 & 13.5 & - & 16.7 & 11 & 15.5 & 17.1 & 15.2 \\
\hline 27 & 13.2 & - & 16.5 & 12 & 15.9 & 17.8 & 15.6 \\
\hline 28 & 13.0 & 13.3 & 16.1 & 13 & 16.2 & 18.4 & 16.0 \\
\hline 29 & 12.6 & 13.0 & 15.9 & 14 & 16.5 & 18.9 & 16.4 \\
\hline 30 & 12.3 & 12.9 & 15.6 & 15 & 16.5 & 18.9 & 16.5 \\
\hline \multicolumn{4}{|c|}{ July } & 16 & 16.3 & 18.7 & 16.4 \\
\hline 1 & 11.8 & 12.6 & 15.4 & 17 & 16.1 & 18.4 & 16.1 \\
\hline 2 & 11.5 & 12.4 & 15.5 & 18 & 15.7 & 17.9 & 16.0 \\
\hline 3 & 11.8 & 12.7 & $\begin{array}{l}15.5 \\
15.9\end{array}$ & 19 & 15.1 & 17.2 & 15.6 \\
\hline 4 & 12.3 & 13.3 & 16.2 & 20 & 14.8 & 16.7 & 15.2 \\
\hline 5 & 12.8 & 13.9 & $\begin{array}{l}10.2 \\
16.6\end{array}$ & 21 & 14.7 & 16.6 & 14.9 \\
\hline 6 & 13.6 & 14.6 & 17.0 & 22 & 14.7 & 16.8 & 14.7 \\
\hline 7 & 14.2 & 15.1 & 17.4 & 23 & 14.8 & 16.7 & 14.7 \\
\hline 8 & 14.9 & 15.7 & 17.9 & 24 & 14.5 & 16.5 & 14.6 \\
\hline 9 & 15.5 & 16.2 & 18.1 & 25 & 14.4 & 16.3 & 14.4 \\
\hline 10 & 15.2 & $\begin{array}{l}10.2 \\
15.9\end{array}$ & $\begin{array}{l}10.1 \\
17.9\end{array}$ & 26 & 14.3 & 16.2 & 14.2 \\
\hline 11 & 15.1 & 15.7 & 17.8 & 27 & 14.2 & 16.0 & 14.2 \\
\hline 12 & 15.0 & 15.7 & 17.7 & 28 & 13.7 & 15.3 & 14.4 \\
\hline 13 & 14.9 & 15.5 & 17.5 & 29 & 13.3 & 14.7 & 14.5 \\
\hline 14 & 14.8 & 15.3 & 172 & 30 & 13.2 & 14.6 & 14.6 \\
\hline & & & 17.2 & 31 & 13.4 & 14.9 & 14.9 \\
\hline
\end{tabular}


Appendix E. Seven-day average of daily maximum temperatures on the White River at Headworks, White River at R Street, and Lake Tapps Diversion (Tailrace), Washington, May-December 2010.-Continued

[7-day average of daily maximum temperatures, degrees Celsius. Abbreviations: -, not available or not applicable]

\begin{tabular}{|c|c|c|c|c|c|c|c|}
\hline Dates & Headworks & R-Street & Tailrace & Dates & Headworks & R-Street & Tailrace \\
\hline \multicolumn{4}{|c|}{ September } & \multicolumn{4}{|c|}{ October-Continued } \\
\hline 1 & 13.6 & 15.0 & 15.1 & 17 & 8.7 & 9.9 & 10.7 \\
\hline 2 & 13.6 & 15.2 & 15.2 & 18 & 8.6 & 9.8 & 10.5 \\
\hline 3 & 13.3 & 14.8 & 15.5 & 19 & 8.6 & 9.9 & 10.5 \\
\hline 4 & 13.3 & 15.0 & 15.4 & 20 & 8.8 & 10.1 & 10.7 \\
\hline 5 & 13.1 & 14.9 & 15.3 & 21 & 9.0 & 10.3 & 11.0 \\
\hline 6 & 12.7 & 14.5 & 15.1 & 22 & 9.0 & 10.3 & 11.3 \\
\hline 7 & 12.2 & 13.9 & 15.0 & 23 & 8.8 & 10.1 & 11.4 \\
\hline 8 & 12.1 & 13.8 & 14.8 & 24 & 8.6 & 9.8 & 11.5 \\
\hline 9 & 12.1 & 13.8 & 14.8 & 25 & 8.4 & 9.6 & 11.6 \\
\hline 10 & 12.5 & 14.3 & 14.6 & 26 & 8.3 & 9.3 & 11.6 \\
\hline 11 & 12.7 & 14.5 & 14.4 & 27 & 8.0 & 9.0 & 11.3 \\
\hline 12 & 12.9 & 14.7 & 14.2 & 28 & 7.9 & 8.9 & 11.1 \\
\hline 13 & 13.1 & 14.9 & 14.4 & 29 & 8.0 & 8.9 & 11.1 \\
\hline 14 & 13.2 & 15.1 & 14.6 & 30 & 8.1 & 9.0 & 11.4 \\
\hline 15 & 13.3 & 15.1 & 15.0 & 31 & 8.2 & 9.1 & 11.7 \\
\hline 16 & 13.4 & 15.0 & 15.4 & \multicolumn{4}{|c|}{ November } \\
\hline 17 & 12.9 & $\begin{array}{l}14.5 \\
141\end{array}$ & 15.6 & 1 & 8.3 & 9.2 & 11.9 \\
\hline 18 & $\begin{array}{l}12.6 \\
123\end{array}$ & 14.1 & $\begin{array}{l}15.6 \\
15.6\end{array}$ & 2 & 8.2 & 9.1 & 12.2 \\
\hline $\begin{array}{l}19 \\
20\end{array}$ & $\begin{array}{l}12.3 \\
12.1\end{array}$ & $\begin{array}{l}13.9 \\
13.5\end{array}$ & $\begin{array}{l}15.6 \\
15.3\end{array}$ & 3 & 8.4 & 9.3 & 12.5 \\
\hline $\begin{array}{l}20 \\
21\end{array}$ & $\begin{array}{l}12.1 \\
12.0\end{array}$ & $\begin{array}{l}13.5 \\
13.3\end{array}$ & $\begin{array}{l}15.3 \\
14.8\end{array}$ & 4 & 8.5 & 9.3 & 12.8 \\
\hline 22 & 11.9 & $\begin{array}{l}15.5 \\
13.2\end{array}$ & $\begin{array}{l}14.0 \\
14.2\end{array}$ & 5 & 8.3 & 9.2 & 12.8 \\
\hline 23 & 11.9 & 13.3 & 13.8 & 6 & 8.0 & 8.8 & 12.7 \\
\hline 24 & 12.1 & 13.7 & 13.6 & 7 & 7.7 & 8.6 & 12.6 \\
\hline 25 & 12.3 & 13.9 & 13.6 & 8 & 7.3 & 8.2 & 12.5 \\
\hline 26 & 12.4 & 14.0 & 13.5 & 9 & 7.0 & 8.0 & 12.3 \\
\hline 27 & 12.7 & 14.4 & 13.4 & 10 & 6.7 & 7.6 & 12.1 \\
\hline 28 & 12.8 & 14.5 & 13.4 & 11 & 6.6 & 7.5 & 11.9 \\
\hline 29 & 12.9 & 14.5 & 13.4 & 12 & 6.7 & 7.6 & 11.8 \\
\hline 30 & 12.8 & 14.3 & 13.2 & 13 & 6.9 & 7.9 & 11.7 \\
\hline \multirow{2}{*}{\multicolumn{4}{|c|}{ October }} & 14 & 7.0 & 7.9 & 11.6 \\
\hline & & & & 15 & 6.9 & 7.8 & 11.5 \\
\hline 1 & 12.5 & 13.9 & 13.0 & 16 & 6.8 & 7.6 & 11.3 \\
\hline 2 & 12.2 & 13.6 & 12.7 & 17 & 6.6 & 7.4 & 11.2 \\
\hline 3 & 11.9 & 13.3 & 12.5 & 18 & 6.1 & 6.9 & 11.0 \\
\hline 4 & 11.5 & 12.9 & 12.3 & 19 & 5.3 & 6.1 & 10.7 \\
\hline 5 & 11.4 & 12.9 & 12.2 & 20 & 4.3 & 5.0 & 10.4 \\
\hline 6 & 11.2 & 12.7 & 12.5 & 21 & 3.4 & 4.0 & 10.0 \\
\hline 7 & 11.1 & 12.5 & 12.9 & 22 & 3.0 & 3.5 & 9.6 \\
\hline 8 & 10.9 & 12.3 & 13.1 & 23 & 2.8 & 3.3 & 9.2 \\
\hline 9 & 10.6 & 11.9 & 13.2 & 24 & 2.7 & 2.9 & 8.8 \\
\hline 10 & 10.4 & 11.7 & 13.2 & 25 & 2.6 & 3.4 & 8.5 \\
\hline 11 & 10.3 & 11.6 & 13.3 & 26 & 2.7 & 3.3 & 8.2 \\
\hline 12 & 10.0 & 11.2 & 13.1 & 27 & 3.1 & 3.8 & 8.0 \\
\hline 13 & 9.5 & 10.7 & 12.6 & 28 & 3.7 & 4.5 & 7.9 \\
\hline 14 & 9.0 & 10.2 & 11.9 & 29 & 4.1 & 4.8 & 7.8 \\
\hline 15 & 8.7 & 10.0 & 11.3 & 30 & 4.2 & 5.0 & 7.8 \\
\hline 16 & 8.7 & 9.9 & 10.9 & & & & \\
\hline
\end{tabular}


Appendix E. Seven-day average of daily maximum temperatures on the White River at Headworks, White River at R Street, and Lake Tapps Diversion (Tailrace), Washington, May-December 2010.-Continued

[7-day average of daily maximum temperatures, degrees Celsius. A bbreviations: -, not available or not applicable]

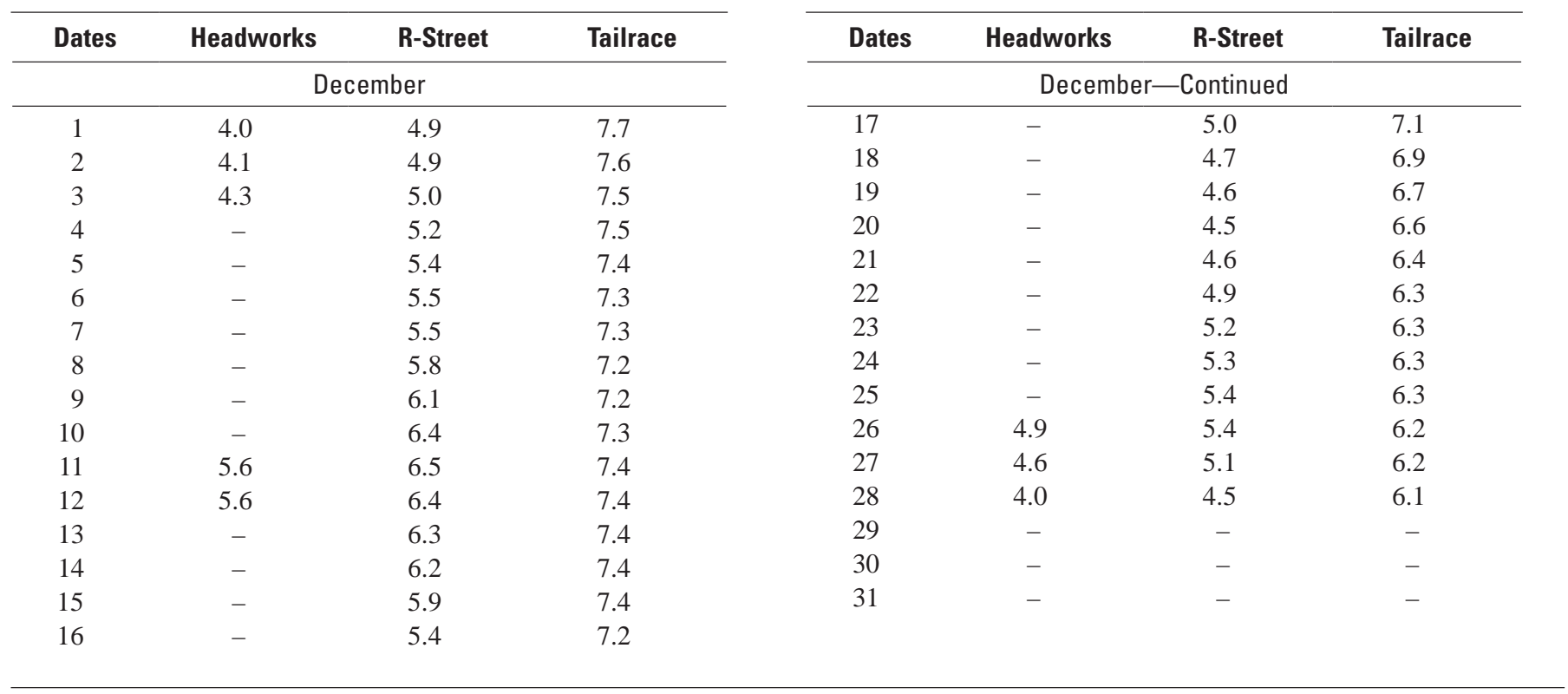




\section{Appendix F. Vertical Profiles of Water-Quality Properties with Depth for Selected Sampling Dates at Nine Sites on Lake Tapps, Washington.}
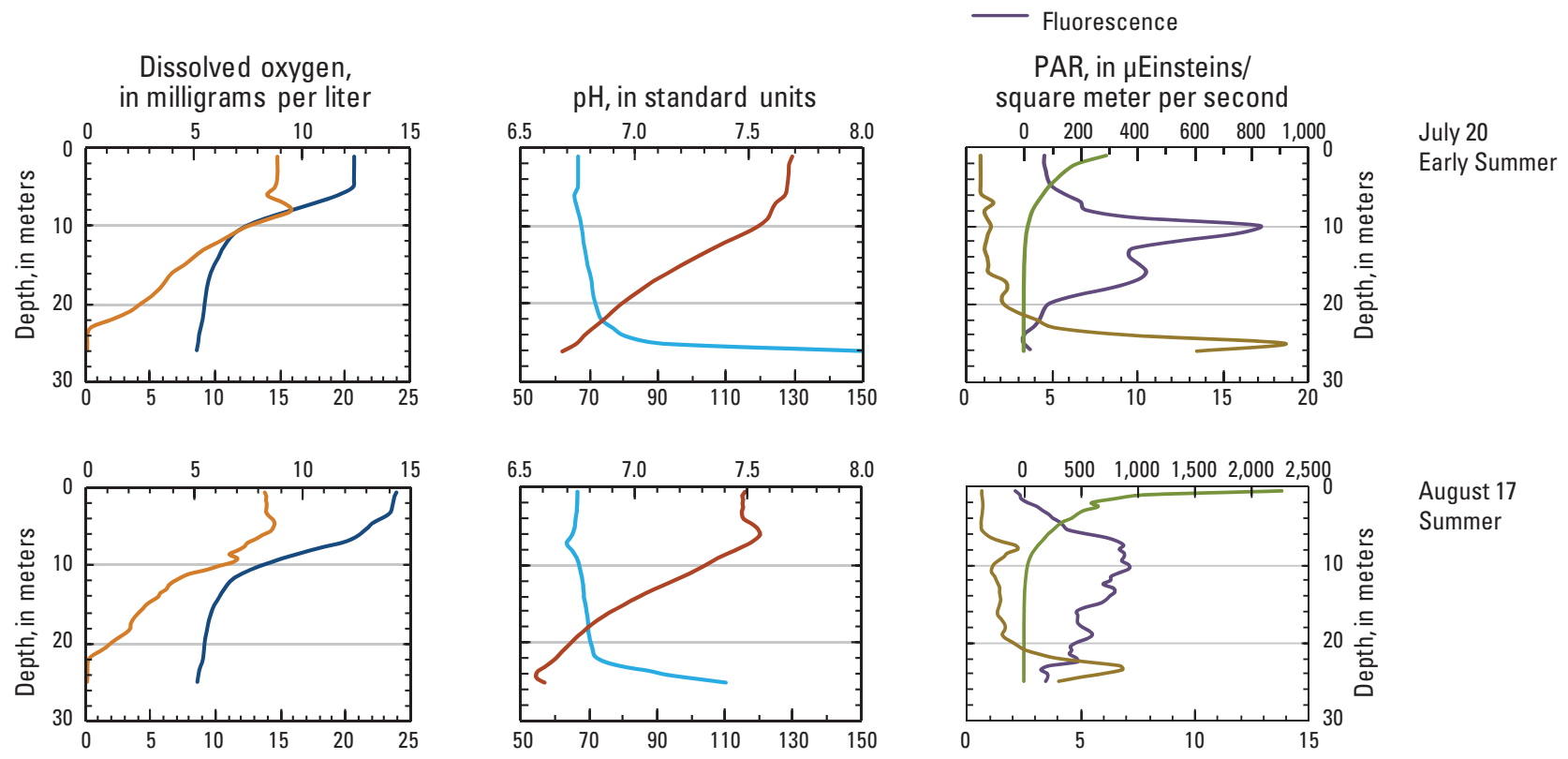

August 17

Summer
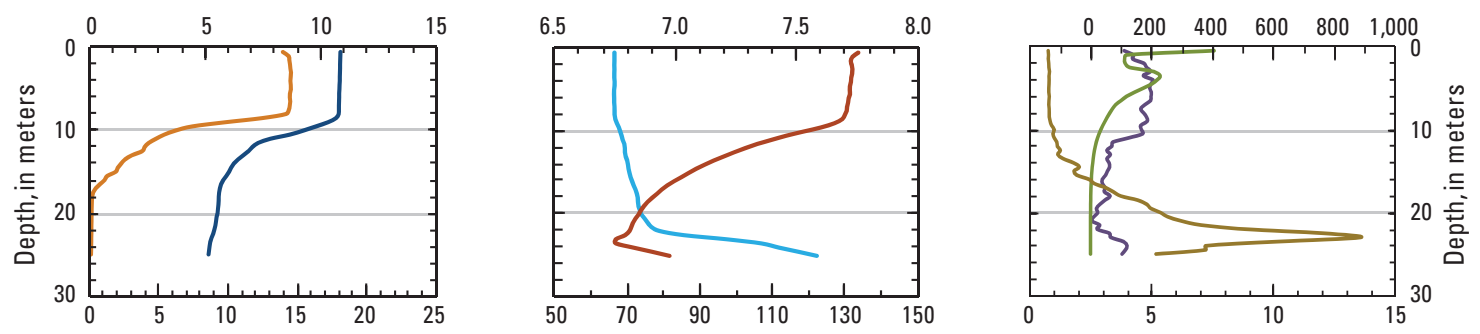

September 21

Late Summer
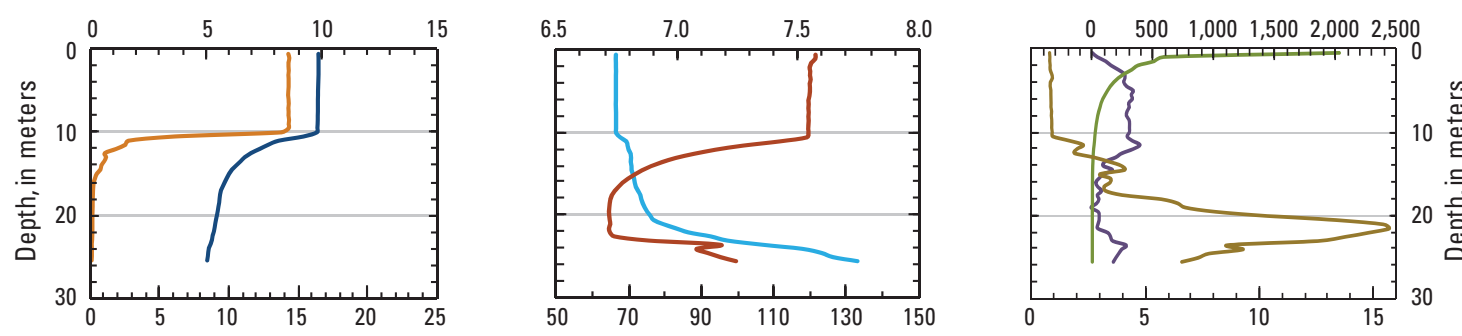

October 12

Fall
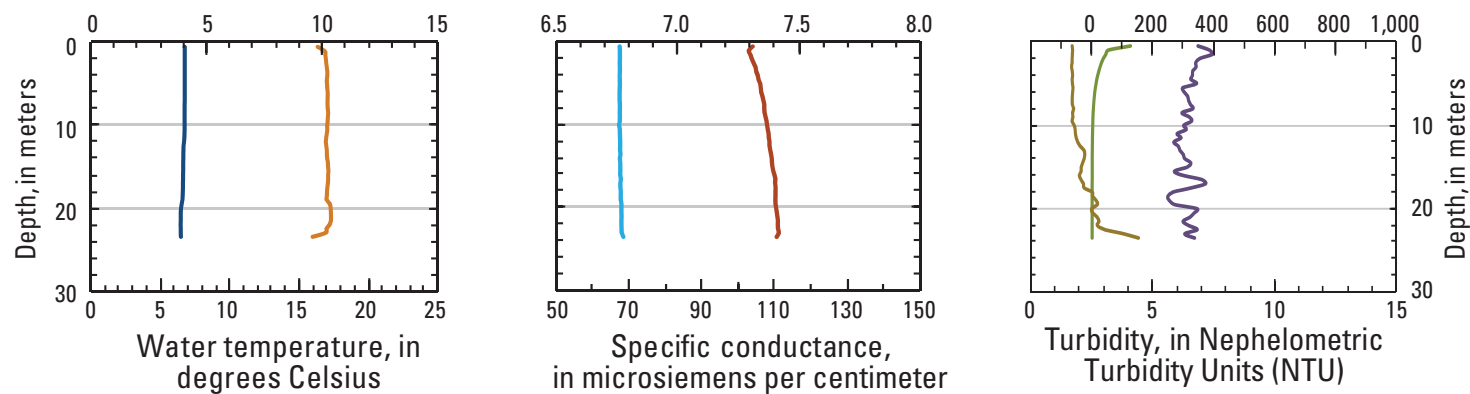

December 7

Late Fall/

Early Winter

in microsiemens per centimete

Fluorescence, in

micrograms per liter $\times 10$

Appendix F1. Representative summer and fall depth profiles of limnological characteristics at the Deep site (map No. L1) on Lake Tapps, Washington. 


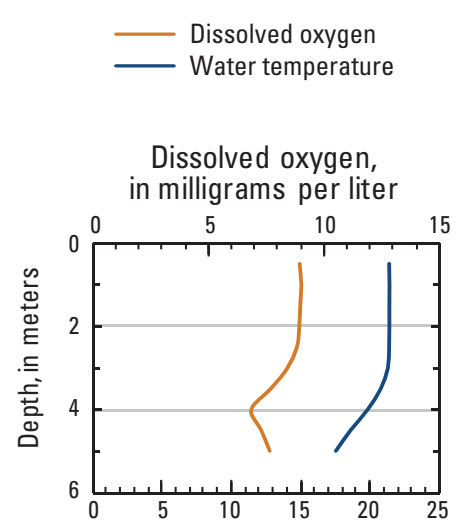

\section{EXPLANATION}

$-\mathrm{pH}$

Specific conductance

$\mathrm{pH}$, in standard units
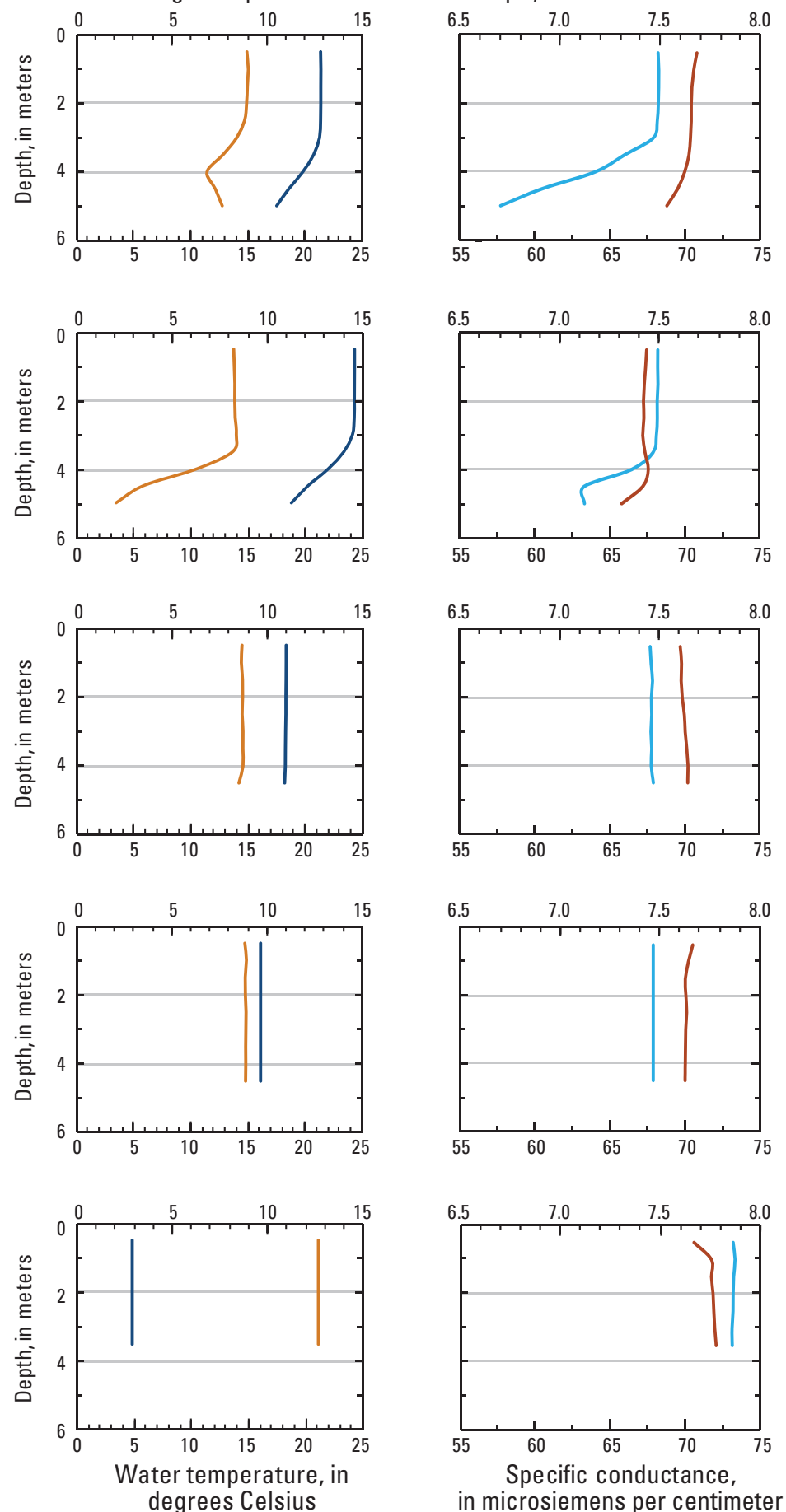

in microsiemens per centimeter

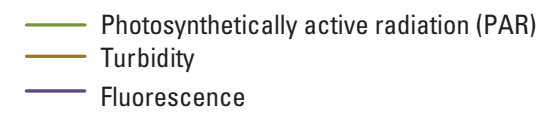

PAR, in $\mu$ Einsteins/ square meter per second

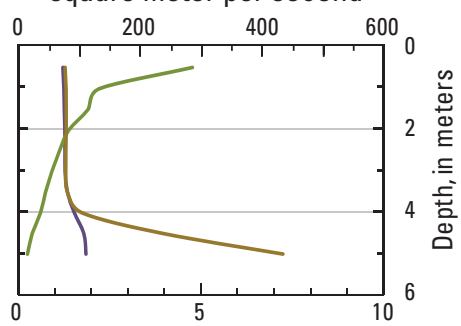

July 20

Early Summer

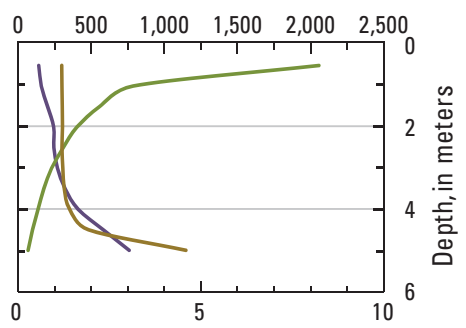

August 17

Summer

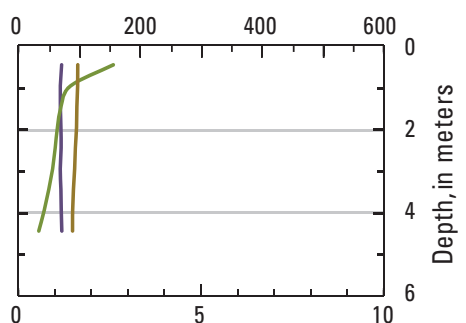

September 21

Late Summer
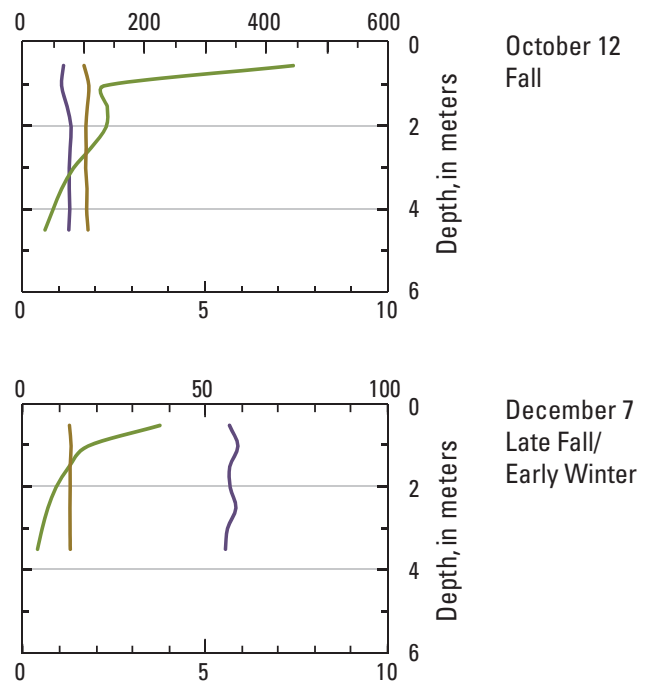

Turbidity, in Nephelometric

Turbidity Units (NTU)

Fluorescence, in micrograms per liter

Appendix F2. Representative summer and fall depth profiles of limnological characteristics at Allan Yorke site (map No. L2) on Lake Tapps, Washington. 

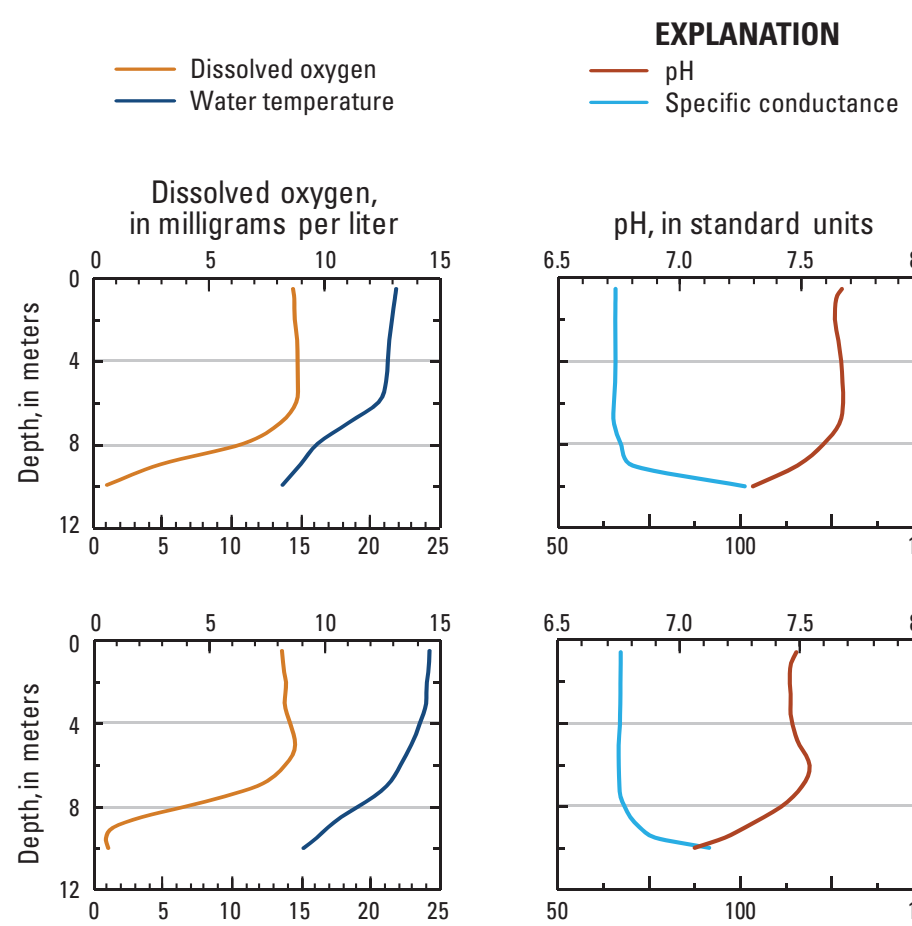

$\mathrm{pH}$, in standard units
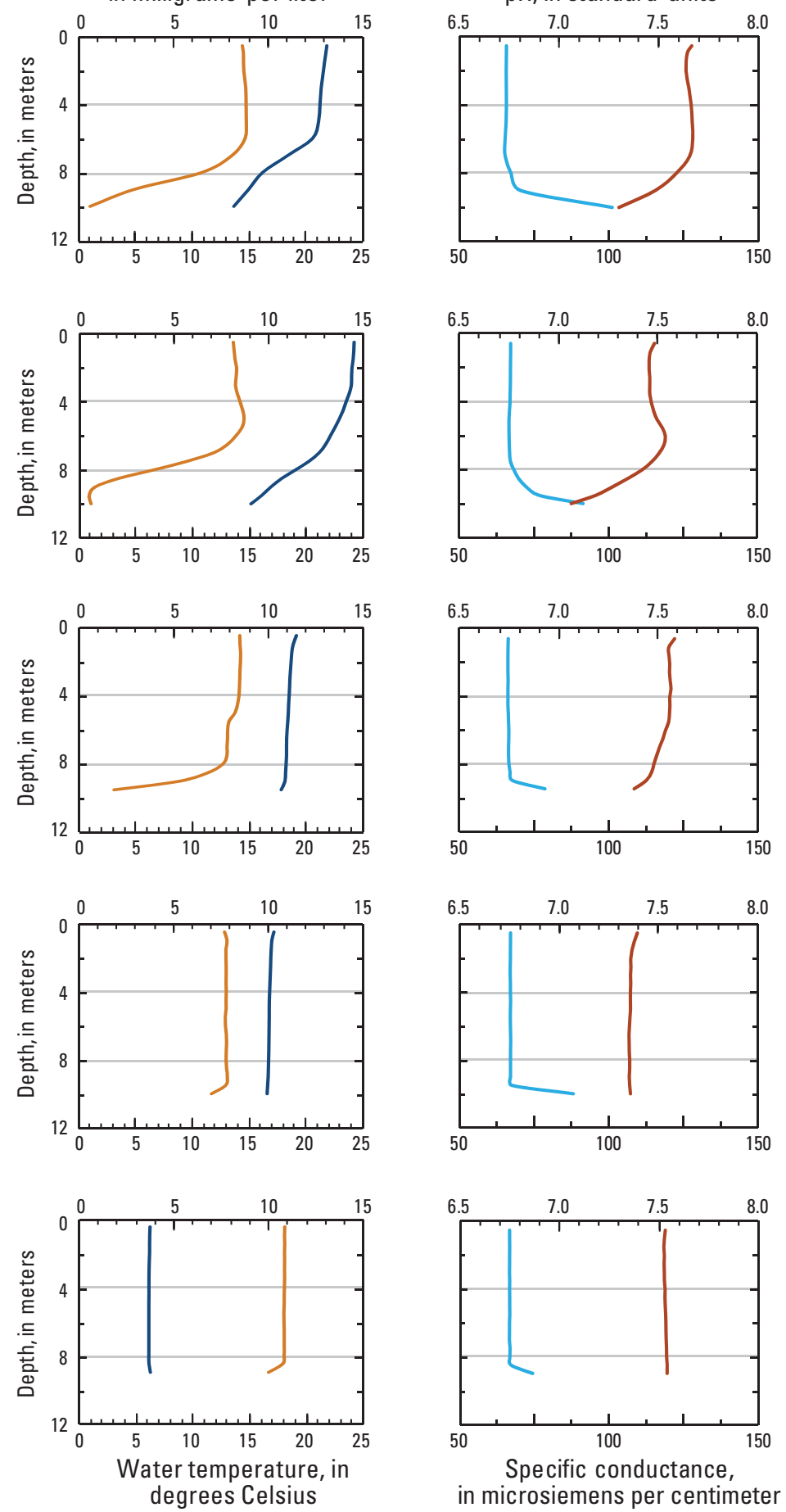

in microsiemens per centimeter

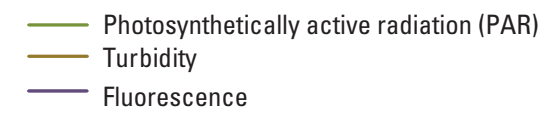

PAR, in $\mu$ Einsteins/ square meter per second

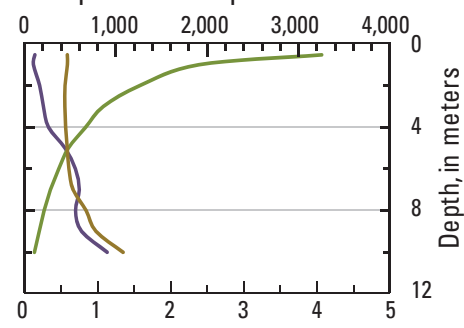

July 21

Early Summer
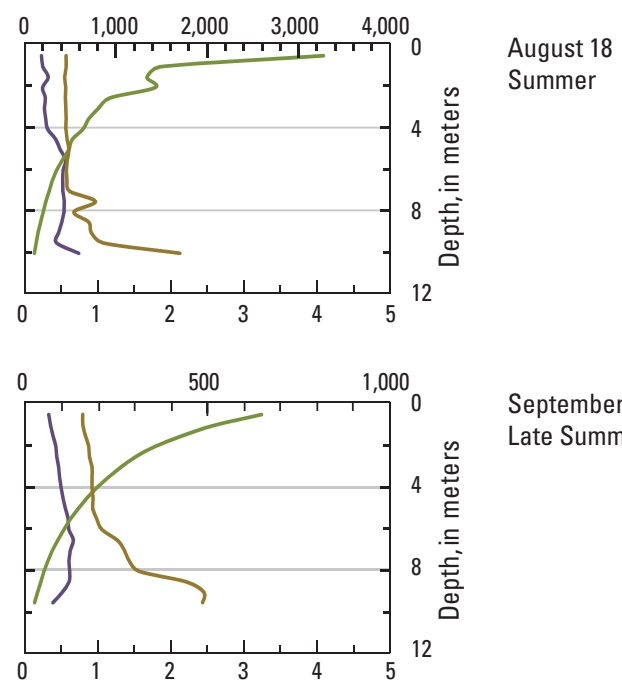

September 22

Late Summer
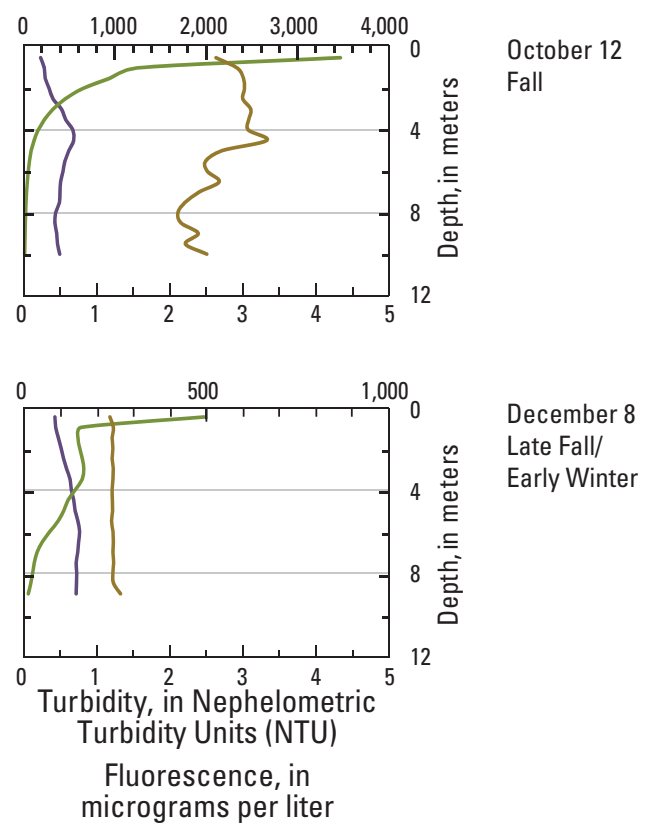

Appendix F3. Representative summer and fall depth profiles of limnological characteristics at Northeast Arm site (map No. L3) on Lake Tapps, Washington. 


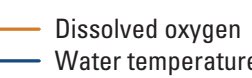

\section{EXPLANATION}

$-\mathrm{pH}$

_- Specific conductance

Dissolved oxygen, in milligrams per liter
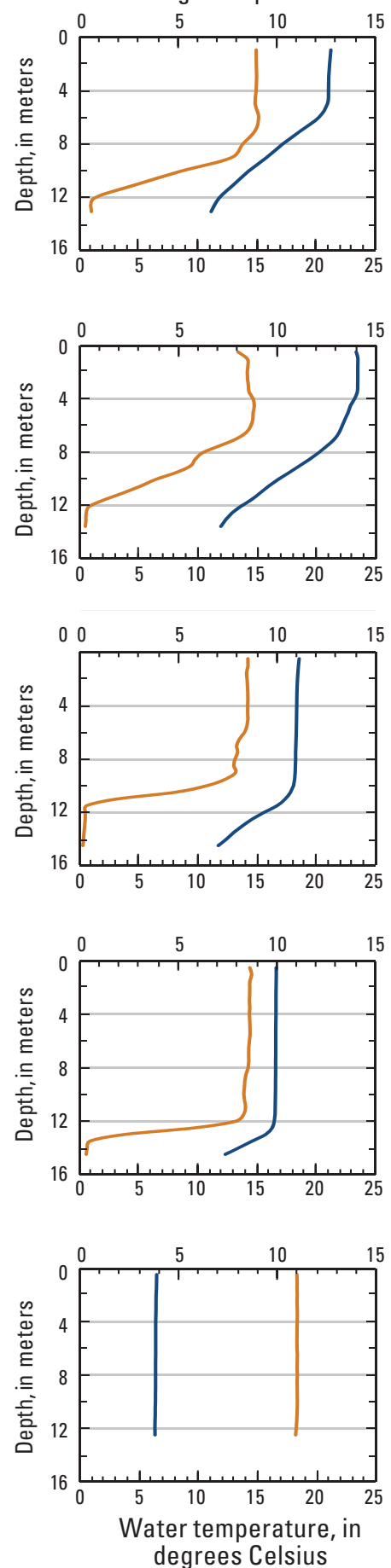

$\mathrm{pH}$, in standard units
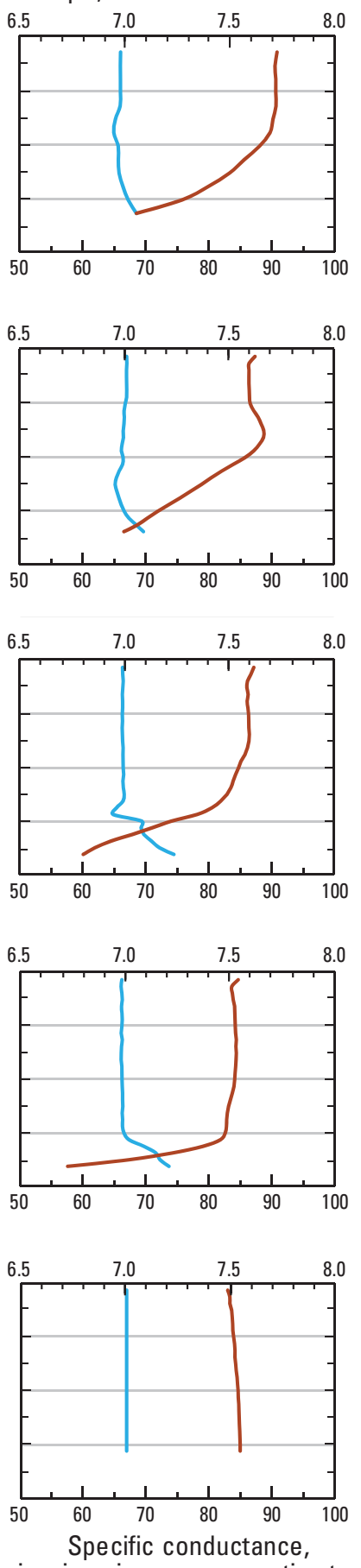

in microsiemens per centimeter

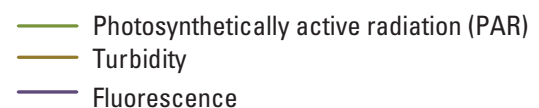

Fluorescence

PAR, in $\mu$ Einsteins/ square meter per second

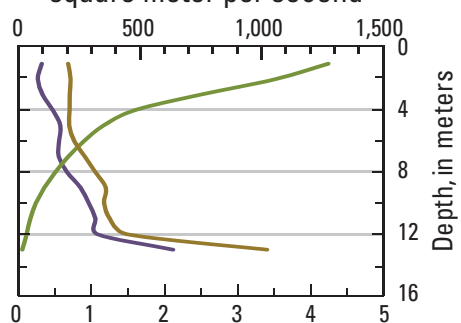

July 21

Early Summer

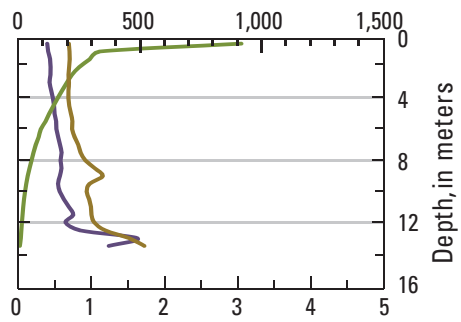

August 18

Summer

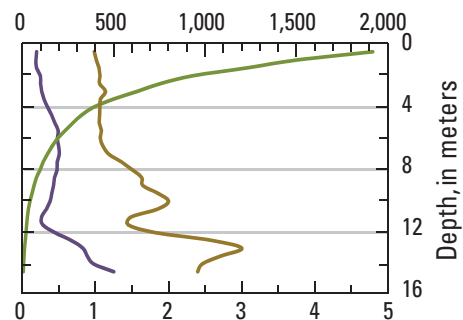

September 22

Late Summer

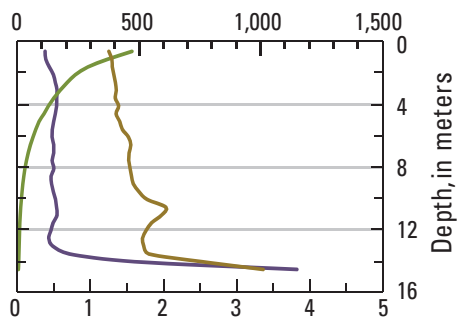

October 13

Fall

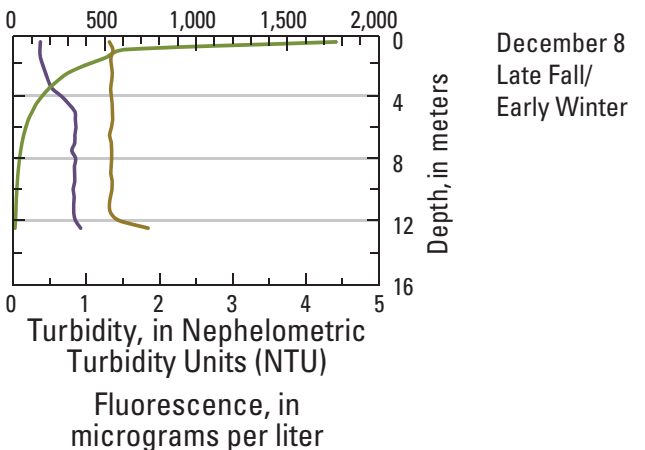

Appendix F4. Representative summer and fall depth profiles of limnological characteristics at Tapps Island site (map No. L4) on Lake Tapps, Washington. 

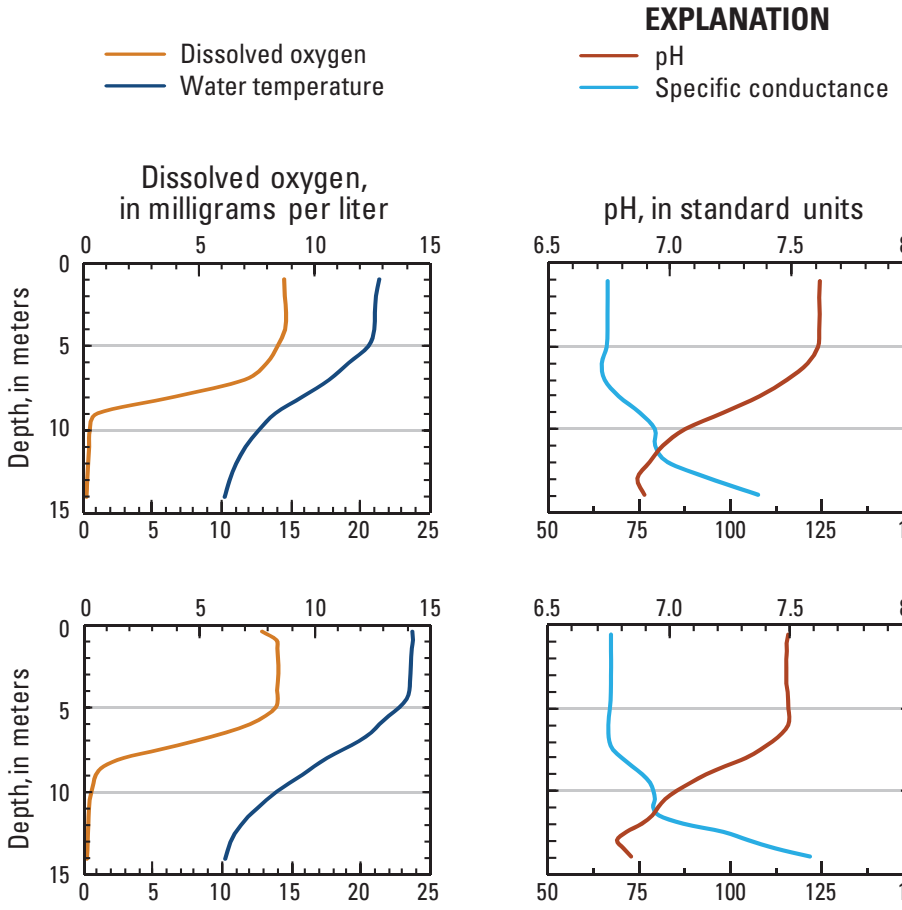

$\mathrm{pH}$, in standard units
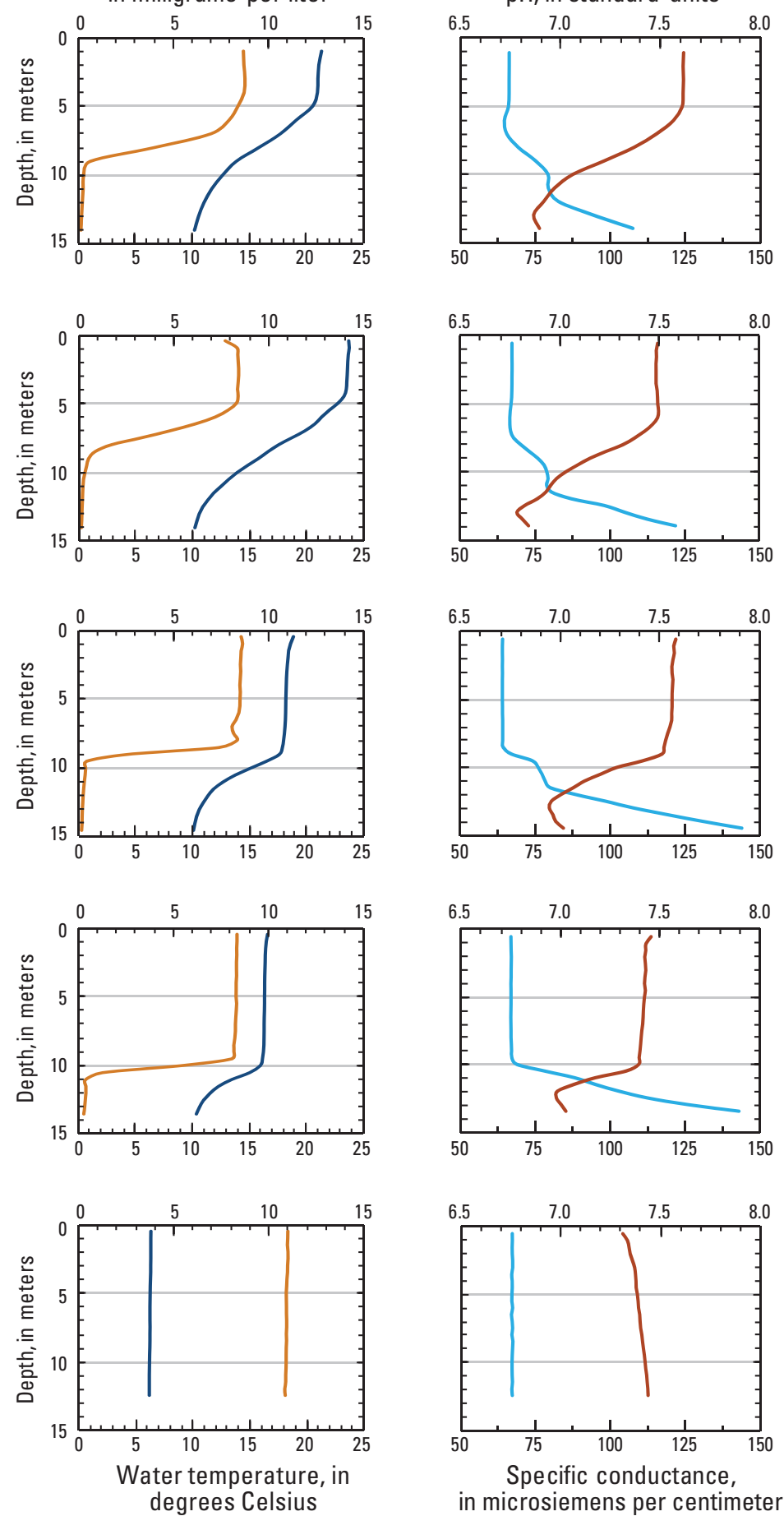

in microsiemens per centimeter

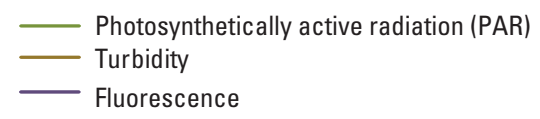

PAR, in $\mu$ Einsteins/ square meter per second

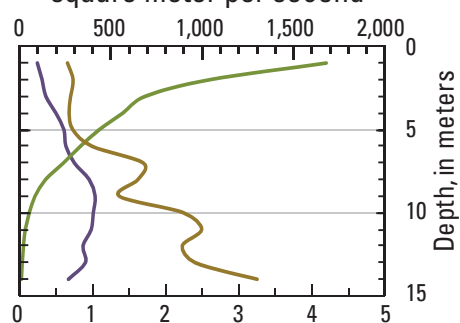

July 21

Early Summer

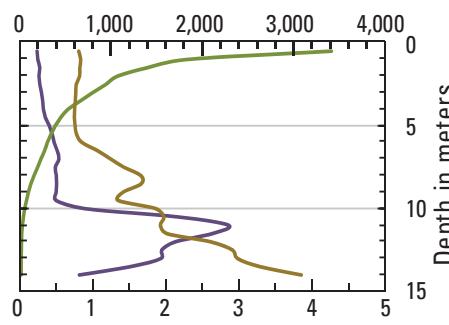

August 18

Summer

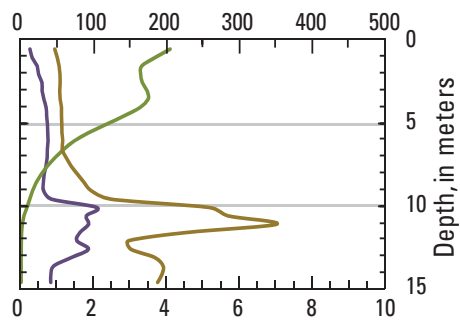

September 22

Late Summer
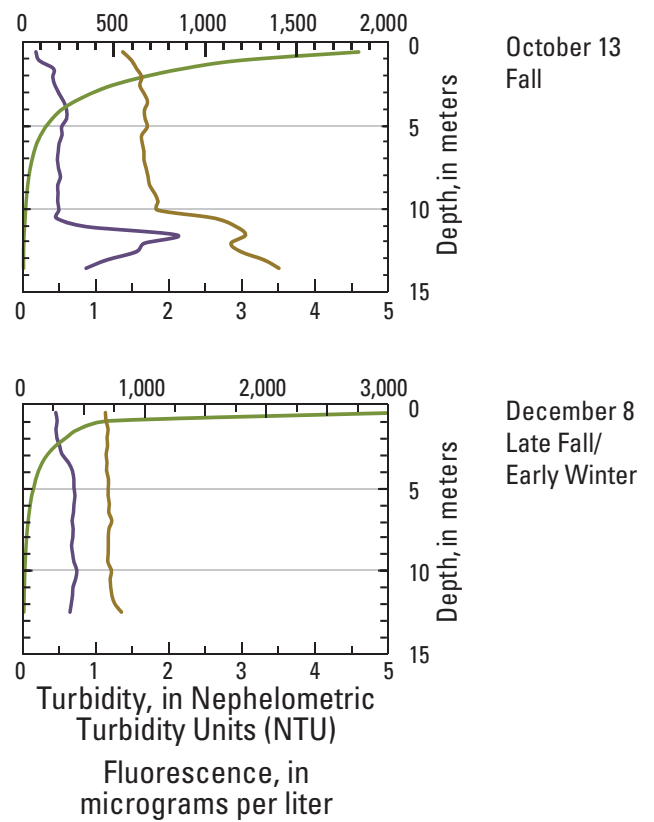

Appendix F5. Representative summer and fall depth profiles of limnological characteristics at Snag Island site (map No. L5) on Lake Tapps, Washington. 


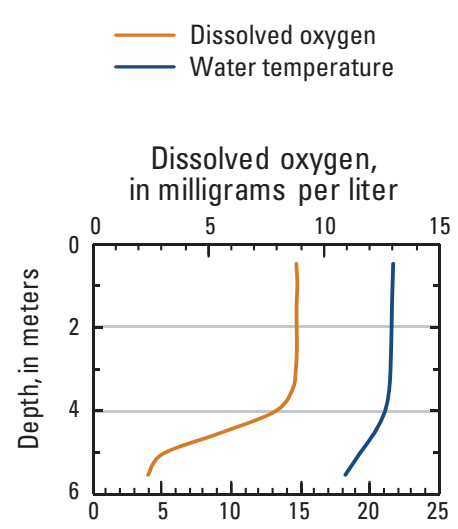

\section{EXPLANATION}

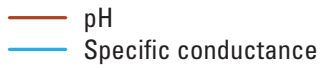

$\mathrm{pH}$, in standard units
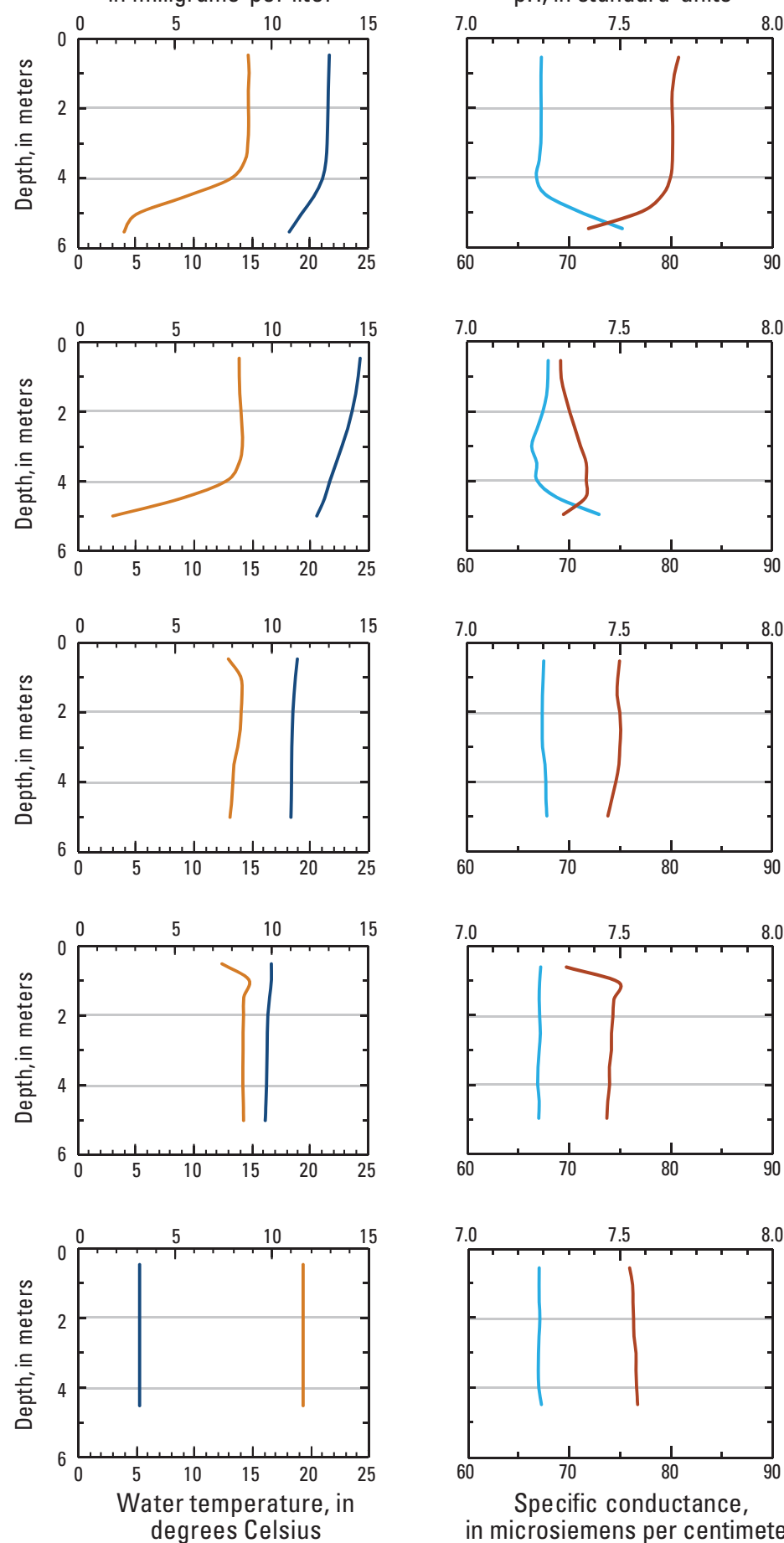
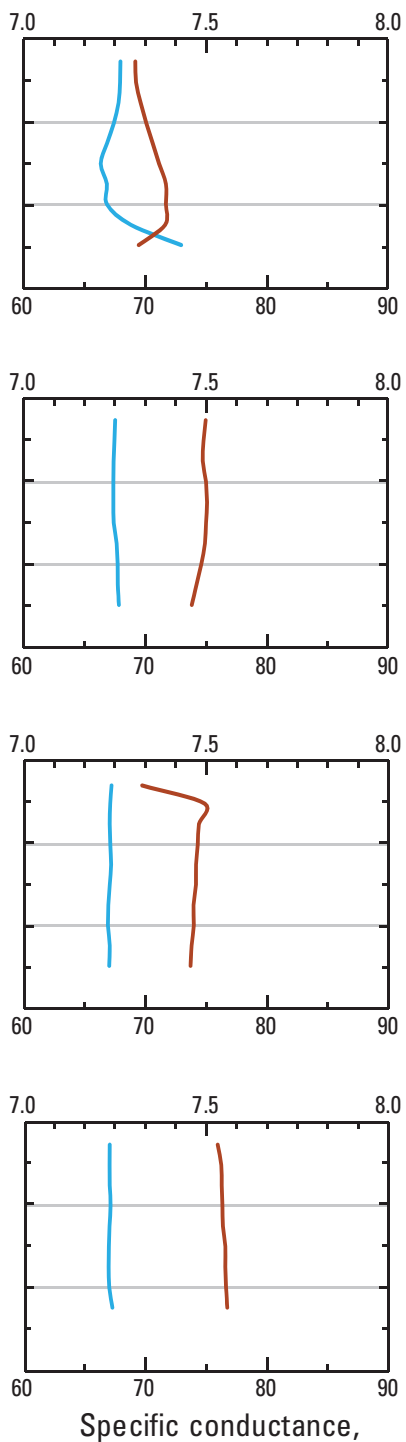

in microsiemens per centimeter

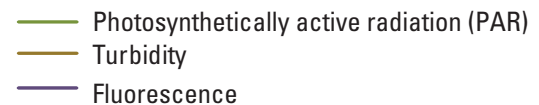

Fluorescence

PAR, in $\mu$ Einsteins/ square meter per second

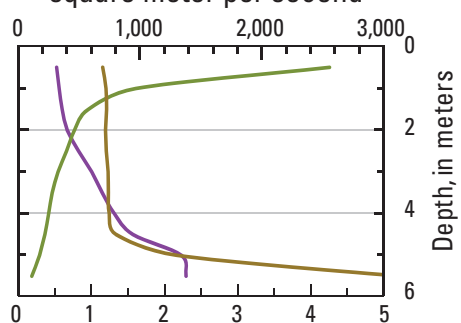

July 20

Early Summer

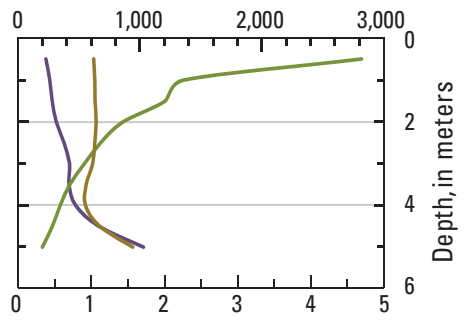

August 17

Summer

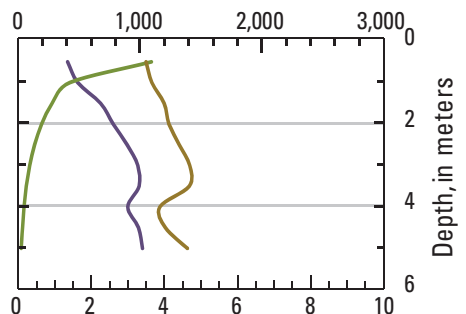

September 21

Late Summer

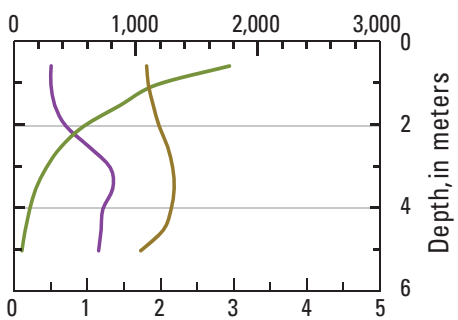

October 12

Fall

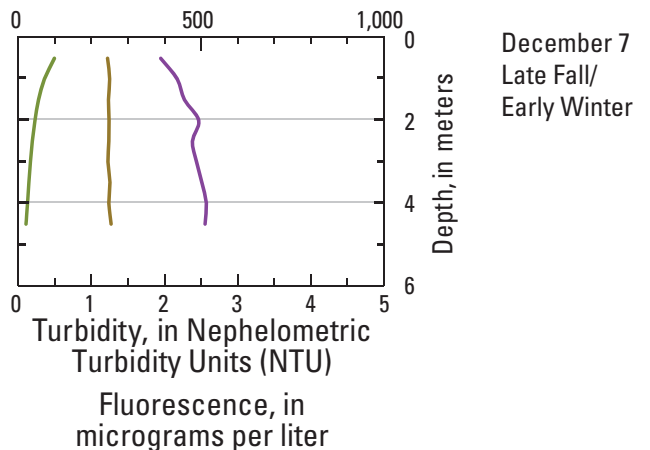

Appendix F6. Representative summer and fall depth profiles of limnological characteristics at Lake Inlet site (map No. L6) on Lake Tapps, Washington. 

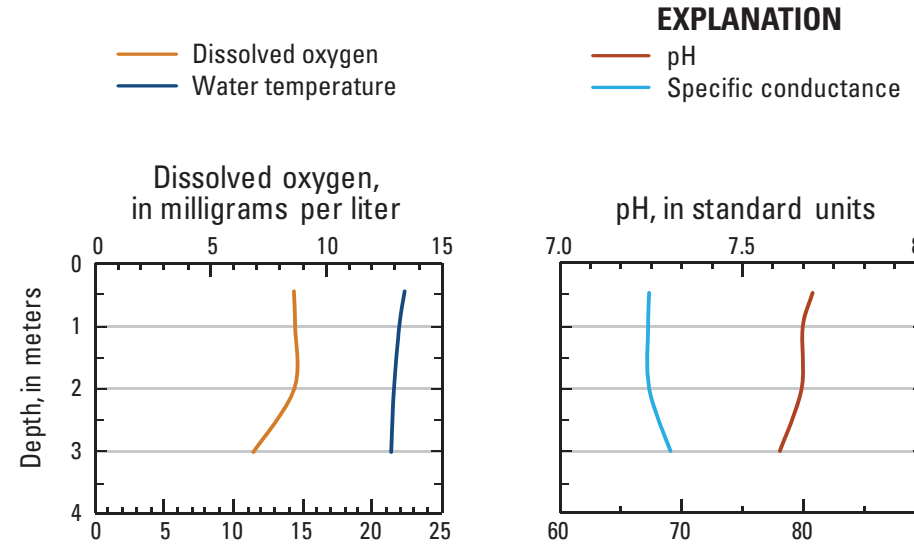

$\mathrm{pH}$, in standard units
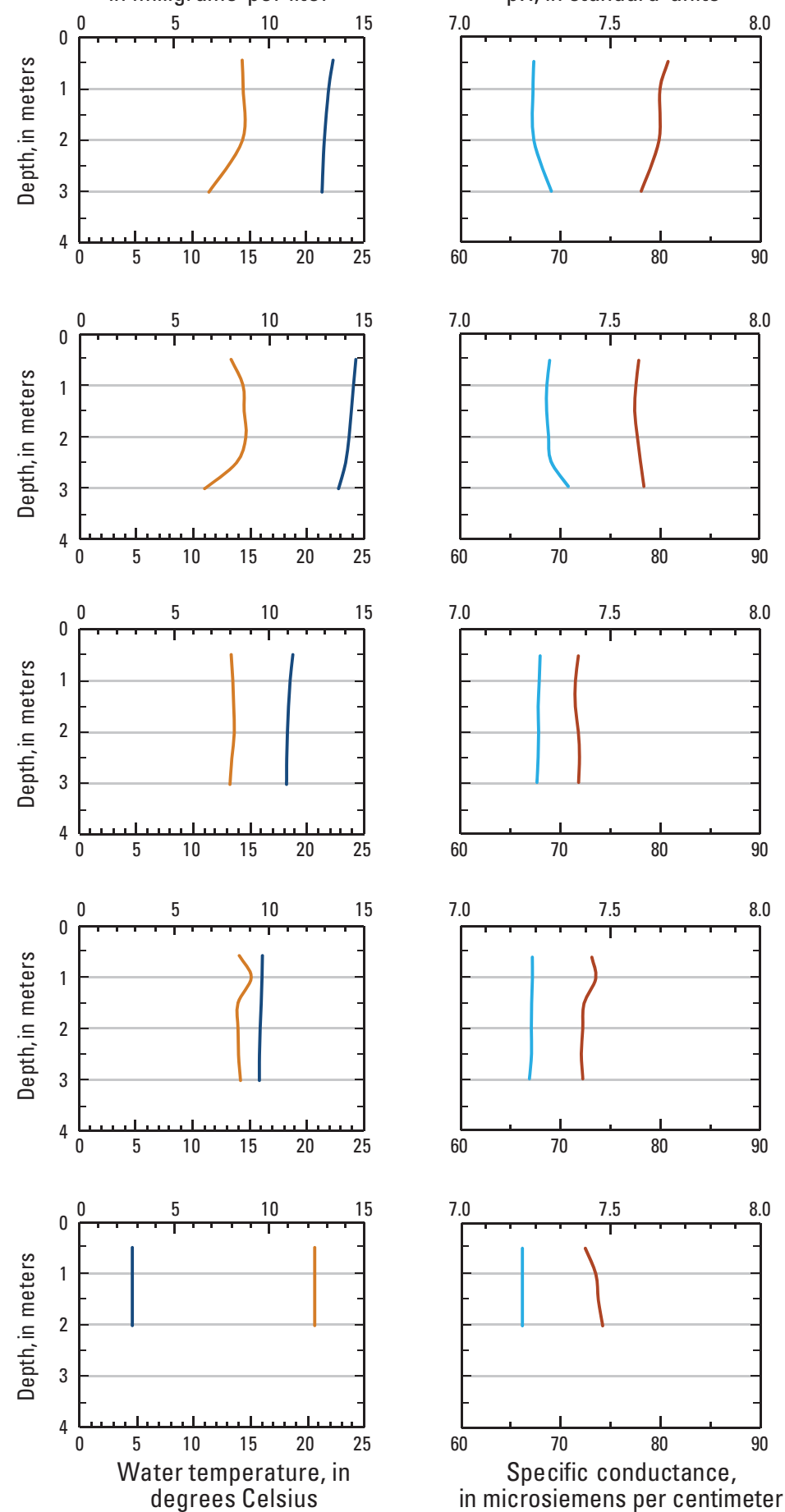

in microsiemens per centimeter

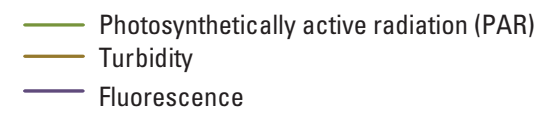

PAR, in $\mu$ Einsteins/ square meter per second
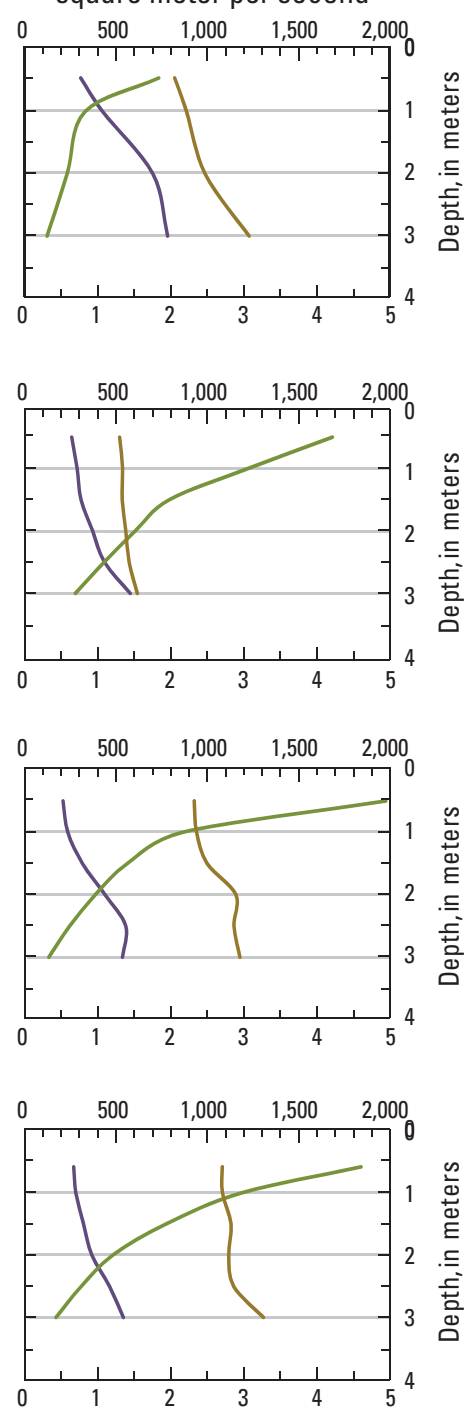

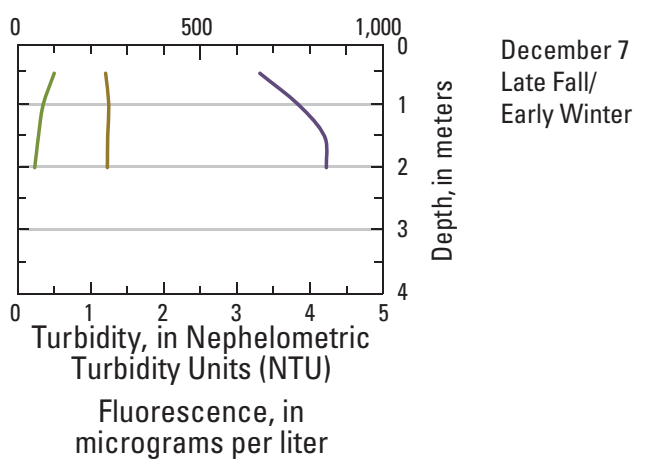

Appendix F7. Representative summer and fall depth profiles of limnological characteristics at Southeast Arm site (map No. L7) on Lake Tapps, Washington. 


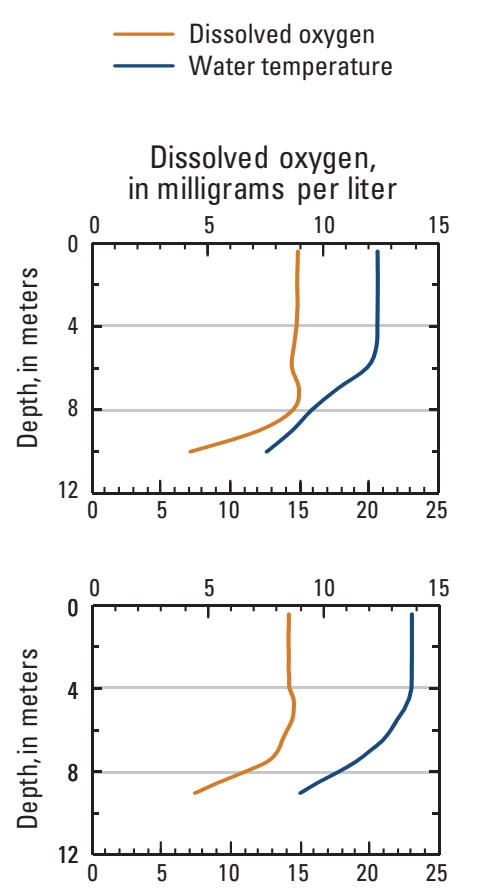

\section{EXPLANATION}

$-\mathrm{pH}$

Specific conductance

$\mathrm{pH}$, in standard units
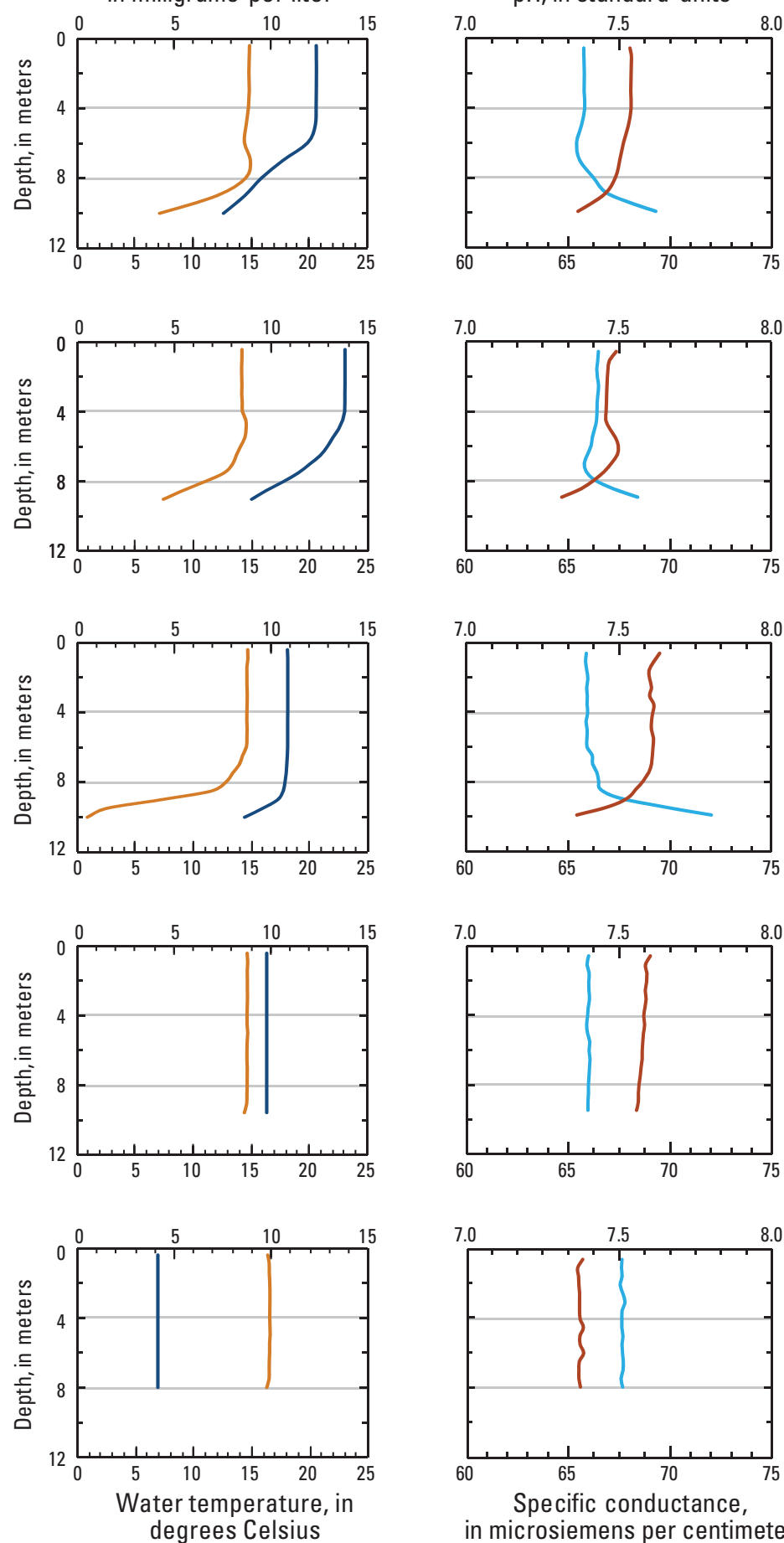
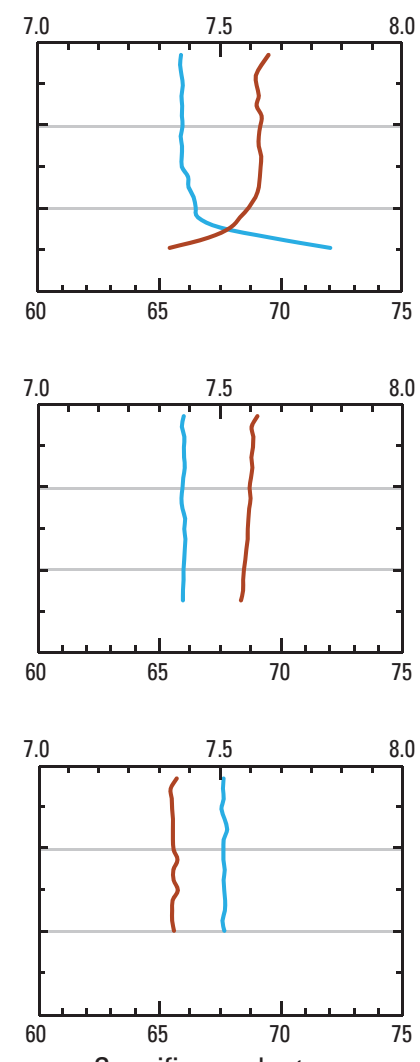

Specific conductance, in microsiemens per centimeter
Photosynthetically active radiation (PAR)

Turbidity

Fluorescence

PAR, in $\mu$ Einsteins/ square meter per second

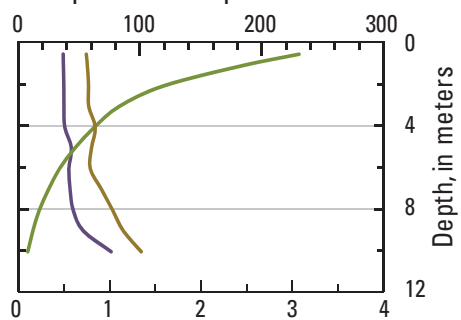

July 20

Early Summer

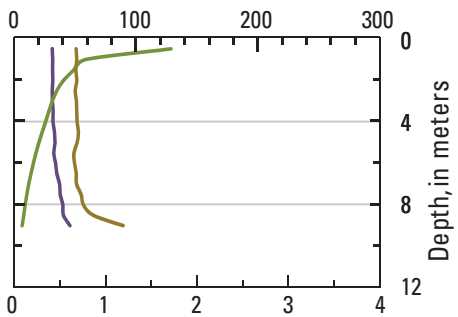

August 18

Summer

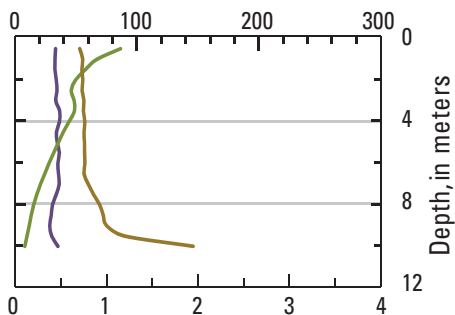

September 22

Late Summer

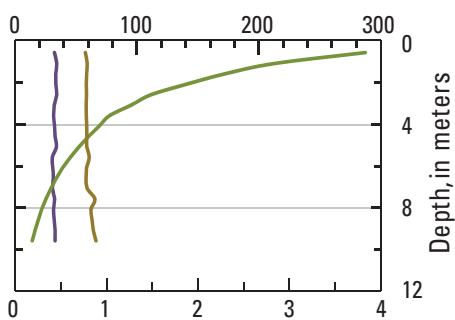

October 13

Fall

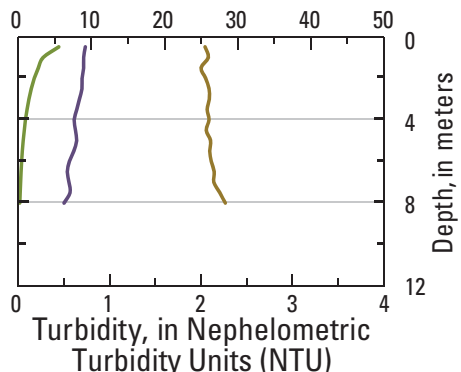

Turbidity Units (NTU)

Fluorescence, in micrograms per liter

Appendix F8. Representative summer and fall depth profiles of limnological characteristics at Lake Outlet site (map No. L8) on Lake Tapps, Washington. 


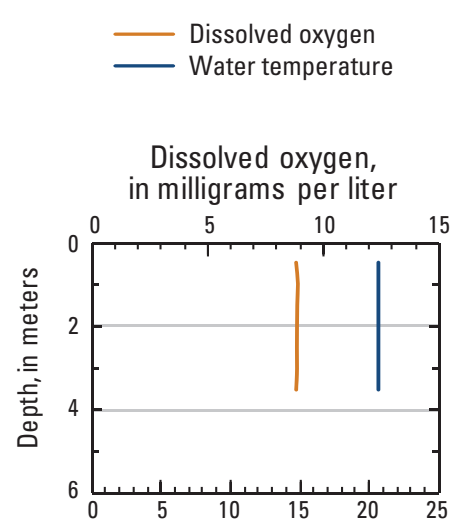

\section{EXPLANATION}

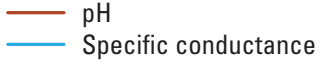

$\mathrm{pH}$, in standard units
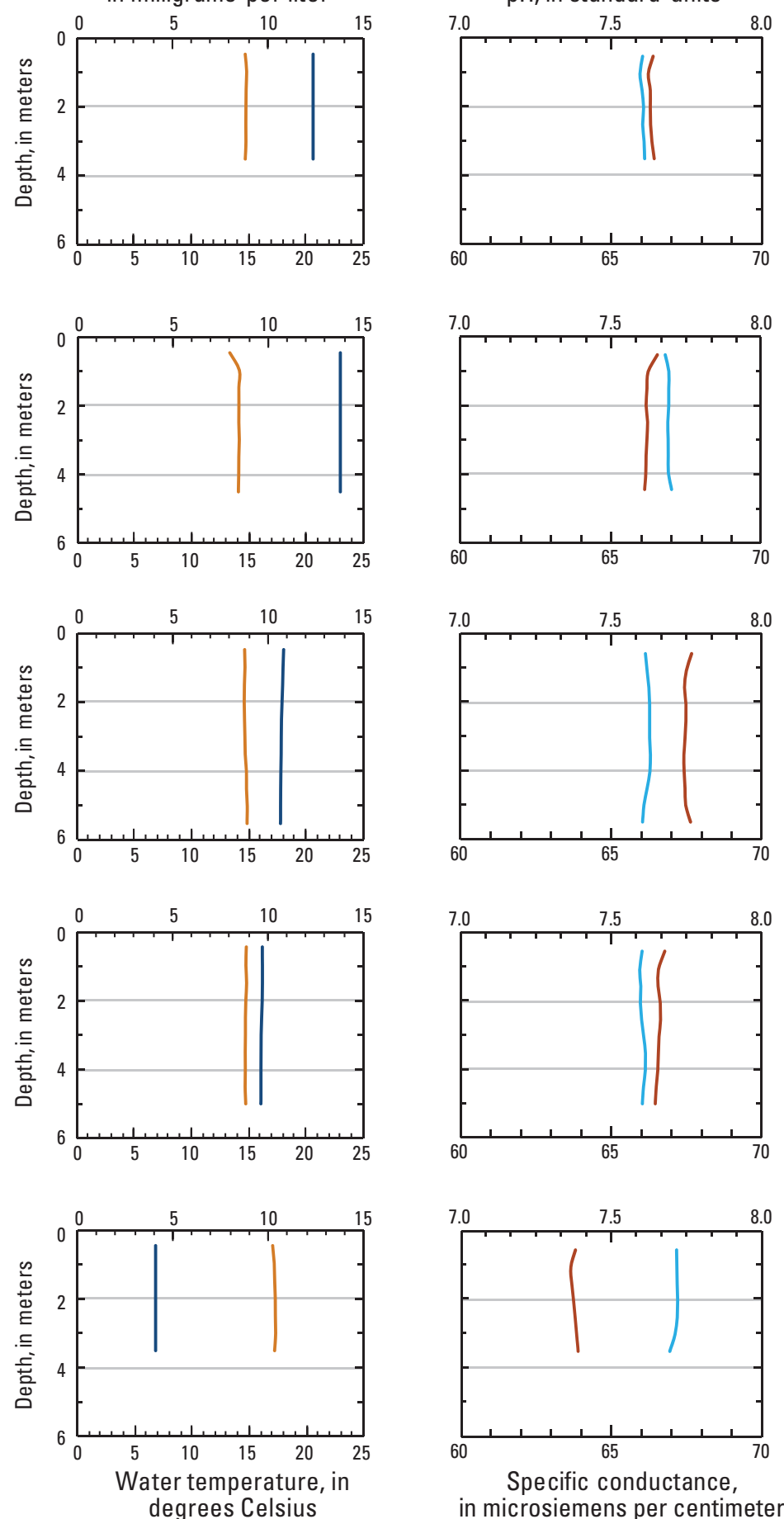

in microsiemens per centimeter

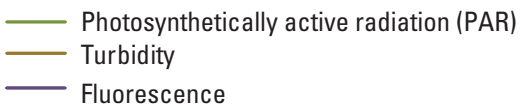

Fluorescence

PAR, in $\mu$ Einsteins/ square meter per second

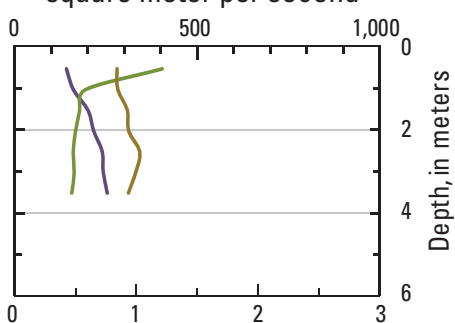

July 21

Early Summer
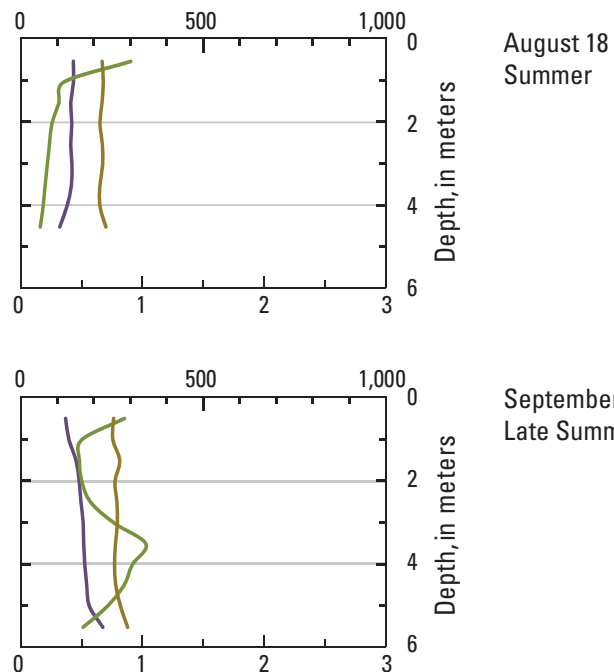

September 22

Late Summer

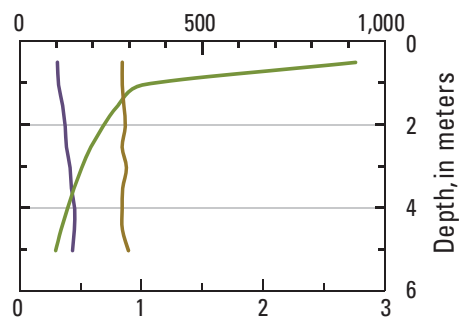

October 13

Fall

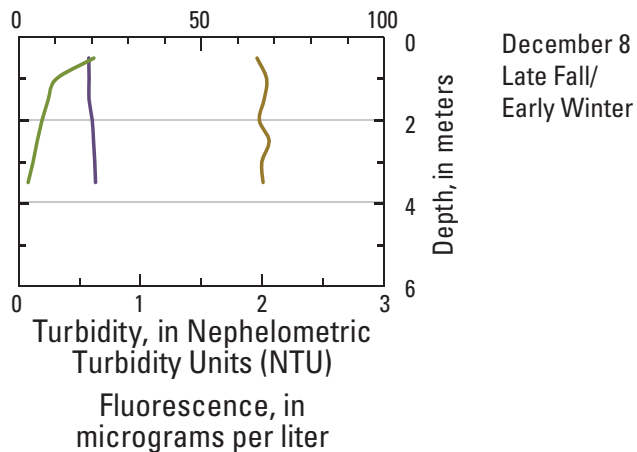

Appendix F9. Representative summer and fall depth profiles of limnological characteristics at Dike 2B site (map No. L9) on Lake Tapps, Washington. 


\section{Appendix G. Pesticides, Wastewater Indicator Chemicals, and Human-Health Pharmaceuticals in Samples from Allan Yorke (map No. L2), Snag Island (map No. L5), and Lake Outlet (map No. L8) Study Sites on Lake Tapps, Washington, September 2010}

[See Appendix C for full names of chemical compounds and other details. Remark codes used in this table: <, less than; E, estimated; M, presence verified, but not quantified; ug/L, micrograms per liter; \%, percent]

\begin{tabular}{|c|c|c|c|c|c|c|c|c|c|c|c|c|}
\hline Station number & & & Station & name & & & Date & Time & $\begin{array}{l}\text { Depth } \\
\text { to bot. } \\
\text { from } \\
\text { surface } \\
\text { at samp } \\
\text { locatn, } \\
\text { meters } \\
(82903)\end{array}$ & $\begin{array}{c}\text { Depth } \\
\text { to } \\
\text { bottom } \\
\text { of } \\
\text { samplng } \\
\text { intrval } \\
\text { meters } \\
(82048)\end{array}$ & $\begin{array}{l}\text { Depth } \\
\text { to } \\
\text { top of } \\
\text { samplng } \\
\text { intrval } \\
\text { meters } \\
(82047)\end{array}$ & $\begin{array}{c}\text { Sam- } \\
\text { pling } \\
\text { depth, } \\
\text { meters } \\
(00098)\end{array}$ \\
\hline 71142122094701 & EPILIMN & ION-LAKE & TAPPS NR & BONNEY LAK & $\mathrm{KE}$, WA SI & TTE 2 & $09-21-10$ & 0910 & 4.70 & -- & - - & 1.0 \\
\hline 1324122093901 & EPIL & IMNION - LA & KE TAPPS & NR SUMNER, & , WA SITE & 5 & $09-22-10$ & 1350 & 14.6 & 9.0 & 1.0 & -- \\
\hline 471423122115001 & EPIL & IMNION-LA & KE TAPPS & NR SUMNER, & , WA SITE & 8 & $09-22-10$ & 0940 & 10.0 & 8.0 & 1.0 & -- \\
\hline Station number & Date & $\begin{array}{l}2,4,5-\mathrm{T} \\
\text { surrog, } \\
\text { water, } \\
\text { fltrd, } \\
\text { percent } \\
\text { recovry } \\
\text { (99958) }\end{array}$ & $\begin{array}{c}\text { alpha- } \\
\text { HCH-d6, } \\
\text { surrog, } \\
\text { Sch2003 } \\
\text { wat flt } \\
\text { percent } \\
\text { recovry } \\
\text { (99995) }\end{array}$ & $\begin{array}{c}\text { Barban, } \\
\text { surrog, } \\
\text { Sched. } \\
2060 / \\
9060, \\
\text { wat flt } \\
\% \text { recvy } \\
(90640)\end{array}$ & $\begin{array}{c}\text { Caf- } \\
\text { feine- } \\
13 C, \\
\text { surrog, } \\
\text { wat flt } \\
\text { percent } \\
\text { recovry } \\
\text { (99959) }\end{array}$ & $\begin{array}{c}\text { Caffe- } \\
\text { ine-13C } \\
\text { sur Sch } \\
2033 \text { \& } \\
8033, \\
\text { wat flt } \\
\% \text { recvy } \\
(99584)\end{array}$ & $\begin{array}{l}\text { Carba- } \\
\text { maze- } \\
\text { pine- } \\
\text {-d10, } \\
\text { surrog, } \\
\text { wat flt } \\
\% \text { recvy } \\
(90797)\end{array}$ & $\begin{array}{c}\text { DecaF- } \\
\text { biphenl } \\
\text { sur Sch } \\
2033 \text { \& } \\
8033, \\
\text { wat flt } \\
\% \text { recvy } \\
\text { (99585) }\end{array}$ & $\begin{array}{c}\text { Diazi- } \\
\text { non-d10 } \\
\text { surrog, } \\
\text { Sch2003 } \\
\text { wat flt } \\
\text { percent } \\
\text { recovry } \\
\text { (99994) }\end{array}$ & $\begin{array}{l}\text { Ethyl } \\
\text { nico- } \\
\text { tinate- } \\
\text { d4, } \\
\text { surrog, } \\
\text { wat flt } \\
\% \text { recvy } \\
(99571)\end{array}$ & $\begin{array}{l}\text { Fluor- } \\
\text { anthene } \\
\text {-d10, } \\
\text { sur Sch } \\
20 / 8033 \\
\text { wat flt } \\
\% \text { recvy } \\
\text { (99586) }\end{array}$ & $\begin{array}{c}\text { 1,4-Di- } \\
\text { chloro- } \\
\text { benzene } \\
\text { water, } \\
\text { fltrd, } \\
\text { ug/L } \\
(34572)\end{array}$ \\
\hline 471142122094701 & $09-21-10$ & 82.5 & 95.8 & 75.0 & 85.7 & 80.7 & 78.3 & 48.2 & 111 & 92.2 & 76.6 & $<.040$ \\
\hline 471324122093901 & 10 & & 94.4 & 91.4 & 9.7 & 80.8 & & & & 92.2 & & $<.0$ \\
\hline 471423122115001 & $09-22-10$ & 75.8 & 96.0 & 86.8 & 87.9 & 83.7 & 74.8 & 47.2 & 116 & 92.8 & 78.3 & $<.040$ \\
\hline Station & Date & $\begin{array}{c}\text { 1-Naph- } \\
\text { thol, } \\
\text { water, } \\
\text { fltrd } \\
0.7 \mathrm{GF} \\
\text { ug/L } \\
(49295)\end{array}$ & $\begin{array}{c}\text { 2, 4-D } \\
\text { methyl } \\
\text { ester, } \\
\text { water, } \\
\text { fltrd, } \\
\text { ug/L } \\
(50470)\end{array}$ & $\begin{array}{c}\text { 2,4-D, } \\
\text { water, } \\
\text { fltrd, } \\
\text { ug/L } \\
(39732)\end{array}$ & $\begin{array}{c}\text { 2, 4-DB, } \\
\text { water, } \\
\text { fltrd } \\
0.7 \mathrm{u} \mathrm{GF} \\
\text { ug/L } \\
(38746)\end{array}$ & $\begin{array}{c}\text { 2,6-Di- } \\
\text { ethyl- } \\
\text { aniline } \\
\text { water, } \\
\text { fltrd } \\
0.7 \mathrm{u} \text { GF } \\
\text { ug/L } \\
(82660)\end{array}$ & $\begin{array}{c}\text { 2Chloro } \\
-2^{\prime} 6^{\prime}- \\
\text { diethyl } \\
\text { acet- } \\
\text { anilide } \\
\text { wat flt } \\
\text { ug/L } \\
(61618)\end{array}$ & $\begin{array}{c}\text { CIAT, } \\
\text { water, } \\
\text { fltrd, } \\
\text { ug/L } \\
(04040)\end{array}$ & $\begin{array}{c}\text { CEAT, } \\
\text { water, } \\
\text { flttd, } \\
\text { ug/L } \\
(04038)\end{array}$ & $\begin{array}{c}2- \\
\text { Ethyl- } \\
6- \\
\text { methyl- } \\
\text { aniline } \\
\text { wat flt } \\
\text { ug/L } \\
(61620)\end{array}$ & $\begin{array}{c}\text { OIET, } \\
\text { water, } \\
\text { fltrd, } \\
\text { ug/L } \\
(50355)\end{array}$ & $\begin{array}{c}\text { 3,4-Di- } \\
\text { chloro- } \\
\text { aniline } \\
\text { water, } \\
\text { fltrd, } \\
\text { ug/L } \\
(61625)\end{array}$ \\
\hline 1142122094701 & & & & .20 & $<.02$ & $<.006$ & & & $<.06$ & $<.010$ & & $<.004$ \\
\hline 71324122093901 & & & & .17 & & & & & $<.0$ & $<.01$ & & $<.004$ \\
\hline 471423122115001 & $09-22-10$ & $<.036$ & $<.200$ & .16 & $<.02$ & $<.006$ & $<.010$ & $<.014$ & $<.06$ & $<.010$ & $<.060$ & $<.004$ \\
\hline Station number & Date & $\begin{array}{c}\text { 3,5-Di- } \\
\text { chloro- } \\
\text { aniline } \\
\text { water, } \\
\text { fltrd, } \\
\text { ug/L } \\
(61627)\end{array}$ & $\begin{array}{c}3- \\
\text { Hydroxy } \\
\text { carbo- } \\
\text { furan, } \\
\text { wat flt } \\
0.7 \mathrm{G} \mathrm{GF} \\
\text { ug/L } \\
(49308)\end{array}$ & $\begin{array}{c}4- \\
\text { Chloro- } \\
2- \\
\text { methyl- } \\
\text { phenol, } \\
\text { wat flt } \\
\text { ug/L } \\
(61633)\end{array}$ & $\begin{array}{c}\text { Aceto- } \\
\text { chlor, } \\
\text { water, } \\
\text { fltrd, } \\
\text { ug/L } \\
(49260)\end{array}$ & $\begin{array}{c}\text { Aci- } \\
\text { fluor- } \\
\text { fen, } \\
\text { water, } \\
\text { fltrd } \\
0.7 \mathrm{G} \text { GF } \\
\text { ug/L } \\
(49315)\end{array}$ & $\begin{array}{c}\text { Ala- } \\
\text { chlor, } \\
\text { water, } \\
\text { fltrd, } \\
\text { ug/L } \\
(46342)\end{array}$ & $\begin{array}{c}\text { Aldi- } \\
\text { carb } \\
\text { sulfone } \\
\text { water, } \\
\text { fltrd } \\
0.7 \mathrm{GF} \\
\text { ug/L } \\
(49313)\end{array}$ & $\begin{array}{c}\text { Aldi- } \\
\text { carb } \\
\text { sulf- } \\
\text { oxide, } \\
\text { wat flt } \\
\Theta .7 \mathrm{u} \text { GF } \\
\text { ug/L } \\
(49314)\end{array}$ & $\begin{array}{l}\text { Aldi- } \\
\text { carb, } \\
\text { water, } \\
\text { fltrd } \\
\oplus .7 \mathrm{u} \mathrm{GF} \\
\text { ug/L } \\
(49312)\end{array}$ & $\begin{array}{c}\text { alpha- } \\
\text { Endo- } \\
\text { sulfan, } \\
\text { water, } \\
\text { fltrd, } \\
\text { ug/L } \\
(34362)\end{array}$ & $\begin{array}{c}\text { Atra- } \\
\text { zine, } \\
\text { water, } \\
\text { fltrd, } \\
\text { ug/L } \\
(39632)\end{array}$ \\
\hline 1142122094701 & $\odot$ & .003 & & & $<$ & $<. \theta$ & & & & & & \\
\hline & & & & & & & & & & & & \\
\hline 471423122115001 & $09-22-10$ & $<.003$ & $<.040$ & $<.003$ & $<.010$ & $<.040$ & $<.008$ & $<.08$ & $<.060$ & $<.12$ & $<.006$ & $<.010$ \\
\hline Station number & Date & $\begin{array}{l}\text { Azin- } \\
\text { phos- } \\
\text { methyl } \\
\text { oxon, } \\
\text { water, } \\
\text { fltrd, } \\
\text { ug/L } \\
(61635)\end{array}$ & $\begin{array}{c}\text { Azin- } \\
\text { phos- } \\
\text { methyl, } \\
\text { water, } \\
\text { fltrd } \\
0.7 \mathrm{G} \mathrm{GF} \\
\text { ug/L } \\
(82686)\end{array}$ & $\begin{array}{c}\text { Bendio- } \\
\text { carb, } \\
\text { water, } \\
\text { fltrd, } \\
\text { ug/L } \\
(50299)\end{array}$ & $\begin{array}{c}\text { Ben- } \\
\text { flur- } \\
\text { alin, } \\
\text { water, } \\
\text { fltrd } \\
\odot .7 \mathrm{u} \mathrm{GF} \\
\text { ug/L } \\
(82673)\end{array}$ & $\begin{array}{c}\text { Benomyl } \\
\text { water, } \\
\text { fltrd, } \\
\text { ug/L } \\
(50300)\end{array}$ & $\begin{array}{c}\text { Bensul- } \\
\text { furon- } \\
\text { methyl, } \\
\text { water, } \\
\text { fltrd, } \\
\text { ug/L } \\
(61693)\end{array}$ & $\begin{array}{c}\text { Ben- } \\
\text { tazon, } \\
\text { water, } \\
\text { fltrd } \\
0.7 \mathrm{GF} \\
\text { ug/L } \\
(38711)\end{array}$ & $\begin{array}{c}\text { Broma- } \\
\text { cil, } \\
\text { water, } \\
\text { fltrd, } \\
\text { ug/L' } \\
(04029)\end{array}$ & $\begin{array}{c}\text { Brom- } \\
\text { oxynil, } \\
\text { water, } \\
\text { fltrd } \\
0.7 \mathrm{u} \mathrm{GF} \\
\text { ug/L } \\
\text { (49311) }\end{array}$ & $\begin{array}{c}\text { Camphor } \\
\text { water, } \\
\text { fltrd, } \\
\text { ug/L } \\
(62070)\end{array}$ & $\begin{array}{c}\text { Car- } \\
\text { baryl, } \\
\text { water, } \\
\text { fltrd } \\
\odot .7 \mathrm{u} \mathrm{GF} \\
\text { ug/L } \\
(49310)\end{array}$ \\
\hline 2094701 & & & & & & & & & & & 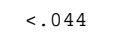 & \\
\hline & & & & & & & & & & & & \\
\hline 471423122115001 & $09-22-10$ & $<.04$ & $<.120$ & $<.04$ & $<.014$ & $<.060$ & $<.06$ & $<.06$ & $<.06$ & $<.12$ & $<.044$ & $<.04$ \\
\hline Station & Date & $\begin{array}{c}\text { Car- } \\
\text { baryl, } \\
\text { water, } \\
\text { fltrd } \\
0.7 \mathrm{G} \text { GF } \\
\text { ug/L } \\
(82680)\end{array}$ & $\begin{array}{l}\text { Carba- } \\
\text { zole, } \\
\text { water, } \\
\text { fltrd, } \\
\text { ug/L } \\
(62071)\end{array}$ & $\begin{array}{c}\text { Carbo- } \\
\text { furan, } \\
\text { water, } \\
\text { fltrd } \\
\odot .7 \mathrm{u} \mathrm{GF} \\
\text { ug/L } \\
(49309)\end{array}$ & $\begin{array}{c}\text { Carbo- } \\
\text { furan, } \\
\text { water, } \\
\text { fltrd } \\
0.7 \mathrm{G} \mathrm{GF} \\
\text { ug/L } \\
(82674)\end{array}$ & $\begin{array}{l}\text { Chlor- } \\
\text { amben } \\
\text { methyl } \\
\text { ester, } \\
\text { water, } \\
\text { fltrd, } \\
\text { ug/L } \\
(61188)\end{array}$ & $\begin{array}{c}\text { Chlori- } \\
\text { muron- } \\
\text { ethyl, } \\
\text { water, } \\
\text { fltrd, } \\
\text { ug/L } \\
(50306)\end{array}$ & $\begin{array}{c}\text { Chlor- } \\
\text { pyrifos } \\
\text { oxon, } \\
\text { water, } \\
\text { fltrd, } \\
\text { ug/L } \\
(61636)\end{array}$ & $\begin{array}{c}\text { Chlor- } \\
\text { pyrifos } \\
\text { water, } \\
\text { fltrd, } \\
\text { ug/L } \\
(38933)\end{array}$ & $\begin{array}{c}\text { cis- } \\
\text { Per- } \\
\text { methrin } \\
\text { water } \\
\text { fltrd } \\
0.7 \mathrm{u} \text { GF } \\
\text { ug/L } \\
(82687)\end{array}$ & $\begin{array}{c}\text { cis- } \\
\text { Propi- } \\
\text { cona- } \\
\text { zole, } \\
\text { water, } \\
\text { fltrd, } \\
\text { ug/L } \\
(79846)\end{array}$ & $\begin{array}{c}\text { Clopyr- } \\
\text { alid, } \\
\text { water, } \\
\text { fltrd } \\
\odot .7 \mathrm{u} \mathrm{GF} \\
\text { ug/L } \\
(49305)\end{array}$ \\
\hline & & & & & & & & & & & & \\
\hline $\begin{array}{l}471324122093901 \\
471423122115001\end{array}$ & $\begin{array}{l}09-22-10 \\
09-22-10\end{array}$ & $\begin{array}{l}<.060 \\
<.060\end{array}$ & $\begin{array}{l}<.030 \\
<.030\end{array}$ & $\begin{array}{l}<.04 \theta \\
<.040\end{array}$ & $\begin{array}{l}<.060 \\
<.060\end{array}$ & $\begin{array}{l}<.10 \\
<.10\end{array}$ & $\begin{array}{l}<.080 \\
<.080\end{array}$ & $<.05$ & $\begin{array}{l}<.010 \\
<.010\end{array}$ & & & $\begin{array}{l}<.06 \\
<.06\end{array}$ \\
\hline
\end{tabular}


Appendix G. Pesticides, Wastewater Indicator Chemicals, and Pharmaceuticals in Samples from Allan Yorke (map No. L2), Snag Island (map No. L5), and Lake Outlet (map no. L8) Study Sites on Lake Tapps, Washington, September 2010

[See Appendix C for full names of chemical compounds and other details. Remark codes used in this table: <, less than; E, estimated; M, presence verified, but not quantified; ug/L, micrograms per liter; \%, percent]

\begin{tabular}{|c|c|c|c|c|c|c|c|c|c|c|c|c|}
\hline Station & Date & $\begin{array}{c}\text { Cyana- } \\
\text { zine, } \\
\text { water, } \\
\text { fltrd, } \\
\text { ug/L } \\
(04041)\end{array}$ & $\begin{array}{c}\text { Cyclo- } \\
\text { ate, } \\
\text { water, } \\
\text { fltrd, } \\
\text { ug/L } \\
(04031)\end{array}$ & $\begin{array}{c}\text { Cyflu- } \\
\text { thrin, } \\
\text { water, } \\
\text { fltrd, } \\
\text { ug/L } \\
\text { (61585) }\end{array}$ & $\begin{array}{c}\text { Cyper- } \\
\text { methrin } \\
\text { water, } \\
\text { fltrd, } \\
\text { ug/L } \\
(61586)\end{array}$ & $\begin{array}{c}\text { DCPA } \\
\text { mono- } \\
\text { acid, } \\
\text { water, } \\
\text { fltrd } \\
\odot .7 \mathrm{u} \mathrm{GF} \\
\text { ug/L } \\
(49304)\end{array}$ & $\begin{array}{c}\text { DCPA, } \\
\text { water, } \\
\text { fltrd } \\
\odot .7 \mathrm{u} \mathrm{GF} \\
\text { ug/L } \\
(82682)\end{array}$ & $\begin{array}{c}\text { DEET, } \\
\text { water, } \\
\text { fltrd, } \\
\text { ug/L } \\
(62082)\end{array}$ & $\begin{array}{c}\text { Desulf- } \\
\text { inyl- } \\
\text { fipro- } \\
\text { nil } \\
\text { amide, } \\
\text { wat flt } \\
\text { ug/L } \\
(62169)\end{array}$ & $\begin{array}{c}\text { Desulf- } \\
\text { inyl- } \\
\text { fipro- } \\
\text { nil, } \\
\text { water, } \\
\text { fltrd, } \\
\text { ug/L } \\
(62170)\end{array}$ & $\begin{array}{c}\text { Diazi- } \\
\text { non, } \\
\text { water, } \\
\text { fltrd, } \\
\text { ug/L } \\
(39572)\end{array}$ & $\begin{array}{c}\text { Dicamba } \\
\text { water, } \\
\text { fltrd } \\
\odot .7 \mathrm{u} \mathrm{GF} \\
\text { ug/L } \\
(38442)\end{array}$ \\
\hline 471142122094701 & $09-21-10$ & $<.022$ & $<.04$ & $<.016$ & $<.020$ & $<.04$ & $<.008$ & M & $<.029$ & E. $\odot \odot 6$ & $<.005$ & $<.04$ \\
\hline 471324122093901 & $09-22-10$ & $<.022$ & $<.04$ & $<.016$ & $<.020$ & $<.04$ & $<.008$ & M & $<.029$ & $<.012$ & $<.005$ & $<.04$ \\
\hline 471423122115001 & $09-22-10$ & $<.022$ & $<.04$ & $<.016$ & $<.020$ & $<.04$ & $<.008$ & M & $<.029$ & $<.012$ & $<.005$ & $<.04$ \\
\hline Station & Date & $\begin{array}{c}\text { Di- } \\
\text { chlor- } \\
\text { prop, } \\
\text { water, } \\
\text { fltrd } \\
\odot .7 \text { u GF } \\
\text { ug/L } \\
(49302)\end{array}$ & $\begin{array}{c}\text { Di- } \\
\text { chlor- } \\
\text { vos, } \\
\text { water, } \\
\text { fltrd, } \\
\text { ug/L } \\
\text { (38775) }\end{array}$ & $\begin{array}{c}\text { Dicro- } \\
\text { tophos, } \\
\text { water, } \\
\text { fltrd, } \\
\text { ug/L } \\
(38454)\end{array}$ & $\begin{array}{c}\text { Diel- } \\
\text { drin, } \\
\text { water, } \\
\text { fltrd, } \\
\text { ug/L } \\
\text { (39381) }\end{array}$ & $\begin{array}{c}\text { Dimeth- } \\
\text { oate, } \\
\text { water, } \\
\text { fltrd } \\
\odot .7 \mathrm{u} \mathrm{GF} \\
\text { ug/L } \\
(82662)\end{array}$ & $\begin{array}{c}\text { Dinoseb } \\
\text { water, } \\
\text { fltrd } \\
\odot .7 \mathrm{u} \mathrm{GF} \\
\text { ug/L } \\
(49301)\end{array}$ & $\begin{array}{l}\text { Diphen- } \\
\text { amid, } \\
\text { water, } \\
\text { fltrd, } \\
\text { ug/L } \\
(04033)\end{array}$ & $\begin{array}{c}\text { Disulf- } \\
\text { oton } \\
\text { sulfone } \\
\text { water, } \\
\text { fltrd, } \\
\text { ug/L } \\
(61640)\end{array}$ & $\begin{array}{c}\text { Disul- } \\
\text { foton, } \\
\text { water, } \\
\text { fltrd } \\
0.7 \mathrm{u} \mathrm{GF} \\
\text { ug/L } \\
(82677)\end{array}$ & $\begin{array}{c}\text { Diuron, } \\
\text { water, } \\
\text { fltrd } \\
0.7 \mathrm{u} \mathrm{GF} \\
\text { ug/L } \\
(49300)\end{array}$ & $\begin{array}{l}\text { Endo- } \\
\text { sulfan } \\
\text { sulfate } \\
\text { water, } \\
\text { fltrd, } \\
\text { ug/L } \\
(61590)\end{array}$ \\
\hline 471142122094701 & $09-21-10$ & $<.04$ & $<.02$ & $<.08$ & $<.009$ & $<.006$ & $<.04$ & $<.04$ & $<.01$ & $<.04$ & $<.04$ & $<.014$ \\
\hline 471324122093901 & $09-22-10$ & $<.04$ & $<.02$ & $<.08$ & $<.009$ & $<.006$ & $<.04$ & $<.04$ & $<.01$ & $<.04$ & E. & $<.014$ \\
\hline 471423122115001 & $09-22-10$ & $<.04$ & $<.02$ & $<.08$ & $<.009$ & $<.006$ & $<.04$ & $<.04$ & $<.01$ & $<.04$ & E.01 & $<.014$ \\
\hline Station & Date & $\begin{array}{c}\text { EPTC, } \\
\text { water, } \\
\text { fltrd } \\
\odot .7 \mathrm{u} \mathrm{GF} \\
\text { ug/L } \\
(82668)\end{array}$ & $\begin{array}{c}\text { Ethion } \\
\text { monoxon } \\
\text { water, } \\
\text { fltrd, } \\
\text { ug/L } \\
(61644)\end{array}$ & $\begin{array}{c}\text { Ethion, } \\
\text { water, } \\
\text { fltrd, } \\
\text { ug/L } \\
(82346)\end{array}$ & $\begin{array}{c}\text { Etho- } \\
\text { prop, } \\
\text { water, } \\
\text { fltrd } \\
\odot .7 \mathrm{u} \mathrm{GF} \\
\text { ug/L } \\
(82672)\end{array}$ & $\begin{array}{c}\text { Fenami- } \\
\text { phos } \\
\text { sulfone } \\
\text { water, } \\
\text { fltrd, } \\
\text { ug/L } \\
(61645)\end{array}$ & $\begin{array}{c}\text { Fenami- } \\
\text { phos } \\
\text { sulf- } \\
\text { oxide, } \\
\text { water, } \\
\text { fltrd, } \\
\text { ug/L } \\
(61646)\end{array}$ & $\begin{array}{c}\text { Fenami- } \\
\text { phos, } \\
\text { water, } \\
\text { fltrd, } \\
\text { ug/L } \\
(61591)\end{array}$ & $\begin{array}{c}\text { Fenuron } \\
\text { water, } \\
\text { fltrd } \\
\odot .7 \text { u GF } \\
\text { ug/L } \\
(49297)\end{array}$ & $\begin{array}{c}\text { Fipro- } \\
\text { nil } \\
\text { sulfide } \\
\text { water, } \\
\text { fltrd, } \\
\text { ug/L } \\
\text { (62167) }\end{array}$ & $\begin{array}{c}\text { Fipro- } \\
\text { nil } \\
\text { sulfone } \\
\text { water, } \\
\text { fltrd, } \\
\text { ug/L } \\
(62168)\end{array}$ & $\begin{array}{c}\text { Fipro- } \\
\text { nil, } \\
\text { water, } \\
\text { fltrd, } \\
\text { ug/L } \\
\text { (62166) }\end{array}$ \\
\hline 471142122094701 & $09-21-10$ & $<. \odot \odot 2$ & $<.02$ & $<.008$ & $<.016$ & $<.053$ & $<.08$ & $<.03$ & $<.06$ & $<.013$ & $<.024$ & $<.018$ \\
\hline $\begin{array}{l}471324122093901 \\
471423122115001\end{array}$ & $\begin{array}{l}09-22-10 \\
09-22-10\end{array}$ & $\begin{array}{l}<.002 \\
<.002\end{array}$ & $\begin{array}{l}<.02 \\
<.02\end{array}$ & $\begin{array}{l}<.008 \\
<.008\end{array}$ & $\begin{array}{l}<.016 \\
<.016\end{array}$ & $\begin{array}{l}<.053 \\
<.053\end{array}$ & $\begin{array}{l}<.08 \\
<.08\end{array}$ & $\begin{array}{l}<.03 \\
<.03\end{array}$ & $\begin{array}{l}<.06 \\
<.06\end{array}$ & $\begin{array}{l}<.013 \\
<.013\end{array}$ & $\begin{array}{l}<.024 \\
<.024\end{array}$ & $\begin{array}{l}<.018 \\
<.018\end{array}$ \\
\hline Station & Date & $\begin{array}{c}\text { Flumet- } \\
\text { sulam, } \\
\text { water, } \\
\text { fltrd, } \\
\text { ug/L } \\
(61694)\end{array}$ & $\begin{array}{c}\text { Fluo- } \\
\text { meturon } \\
\text { water, } \\
\text { fltrd } \\
\odot .7 \mathrm{u} \mathrm{GF} \\
\text { ug/L } \\
(38811)\end{array}$ & $\begin{array}{c}\text { Fluri- } \\
\text { done, } \\
\text { wat flt } \\
\text { ug/L } \\
(65216)\end{array}$ & $\begin{array}{c}\text { Fonofos } \\
\text { water, } \\
\text { fltrd, } \\
\text { ug/L } \\
(04095)\end{array}$ & $\begin{array}{c}\text { Hexa- } \\
\text { zinone, } \\
\text { water, } \\
\text { fltrd, } \\
\text { ug/L } \\
(04025)\end{array}$ & $\begin{array}{c}\text { Imaza- } \\
\text { quin, } \\
\text { water, } \\
\text { fltrd, } \\
\text { ug/L } \\
(50356)\end{array}$ & $\begin{array}{c}\text { Imaze- } \\
\text { thapyr, } \\
\text { water, } \\
\text { fltrd, } \\
\text { ug/L } \\
(50407)\end{array}$ & $\begin{array}{c}\text { Imida- } \\
\text { cloprid } \\
\text { water, } \\
\text { fltrd, } \\
\text { ug/L } \\
(61695)\end{array}$ & $\begin{array}{c}\text { Ipro- } \\
\text { dione, } \\
\text { water, } \\
\text { fltrd, } \\
\text { ug/L } \\
(61593)\end{array}$ & $\begin{array}{c}\text { Isofen- } \\
\text { phos, } \\
\text { water, } \\
\text { fltrd, } \\
\text { ug/L } \\
(61594)\end{array}$ & $\begin{array}{c}\text { lambda- } \\
\text { Cyhalo- } \\
\text { thrin, } \\
\text { water, } \\
\text { fltrd, } \\
\text { ug/L } \\
(61595)\end{array}$ \\
\hline 471142122094701 & $9-21-10$ & $<. \odot$ & $<.0$ & 2.0 & 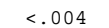 & $<. \odot \odot 8$ & $<$. & $<$. & & $<.014$ & & \\
\hline 471324122093901 & $09-22-10$ & $<.06$ & $<.04$ & 1.02 & $<.004$ & $<.008$ & $<.06$ & $<.06$ & $<.060$ & $<.014$ & $<.006$ & $<.010$ \\
\hline 471423122115001 & $09-22-10$ & $<.06$ & $<.04$ & .308 & $<.004$ & $<.008$ & $<.06$ & $<.06$ & $<.060$ & $<.014$ & $<.006$ & $<.010$ \\
\hline Station & Date & $\begin{array}{c}\text { Linuron } \\
\text { water, } \\
\text { fltrd } \\
0.7 \mathrm{u} \mathrm{GF} \\
\text { ug/L } \\
(38478)\end{array}$ & $\begin{array}{c}\text { Mala- } \\
\text { oxon, } \\
\text { water, } \\
\text { fltrd, } \\
\text { ug/L } \\
(61652)\end{array}$ & $\begin{array}{c}\text { Mala- } \\
\text { thion, } \\
\text { water, } \\
\text { fltrd, } \\
\text { ug/L } \\
\text { (39532) }\end{array}$ & $\begin{array}{c}\text { MCPA, } \\
\text { water, } \\
\text { fltrd } \\
\odot .7 \mathrm{u} \mathrm{GF} \\
\text { ug/L } \\
(38482)\end{array}$ & $\begin{array}{c}\text { MCPB, } \\
\text { water, } \\
\text { fltrd } \\
0.7 \mathrm{u} \mathrm{GF} \\
\text { ug/L } \\
(38487)\end{array}$ & $\begin{array}{c}\text { Meta- } \\
\text { laxyl, } \\
\text { water, } \\
\text { fltrd, } \\
\text { ug/L } \\
(50359)\end{array}$ & $\begin{array}{c}\text { Meta- } \\
\text { laxyl, } \\
\text { water, } \\
\text { fltrd, } \\
\text { ug/L } \\
(61596)\end{array}$ & $\begin{array}{c}\text { Methid- } \\
\text { athion, } \\
\text { water, } \\
\text { fltrd, } \\
\text { ug/L } \\
(61598)\end{array}$ & $\begin{array}{c}\text { Methio- } \\
\text { carb, } \\
\text { water, } \\
\text { fltrd } \\
\odot .7 \mathrm{u} \mathrm{GF} \\
\text { ug/L } \\
(38501)\end{array}$ & $\begin{array}{c}\text { Meth- } \\
\text { omyl, } \\
\text { water, } \\
\text { fltrd } \\
\odot .7 \mathrm{u} \mathrm{GF} \\
\text { ug/L } \\
(49296)\end{array}$ & $\begin{array}{c}\text { Methyl } \\
\text { para- } \\
\text { oxon, } \\
\text { water, } \\
\text { fltrd, } \\
\text { ug/L } \\
(61664)\end{array}$ \\
\hline $\begin{array}{l}471142122094701 \\
471324122093901 \\
471423122115001\end{array}$ & $\begin{array}{l}09-21-10 \\
09-22-10 \\
09-22-10\end{array}$ & $\begin{array}{l}<.04 \\
<.04 \\
<.04\end{array}$ & $\begin{array}{l}<.080 \\
<.080 \\
<.080\end{array}$ & $\begin{array}{l}<.016 \\
<.016 \\
<.016\end{array}$ & $\begin{array}{l}<.04 \\
<.04 \\
<.04\end{array}$ & $\begin{array}{l}<.20 \\
<.20 \\
<.20\end{array}$ & $\begin{array}{l}<.04 \\
<.04 \\
<.04\end{array}$ & $\begin{array}{l}<.007 \\
<.007 \\
<.007\end{array}$ & $\begin{array}{l}<.006 \\
<.006 \\
<.006\end{array}$ & $\begin{array}{l}<.040 \\
<.040 \\
<.04 \Theta\end{array}$ & $\begin{array}{l}<.120 \\
<.120 \\
<.120\end{array}$ & $\begin{array}{l}<.01 \\
<.01 \\
<.01\end{array}$ \\
\hline Station & Date & $\begin{array}{c}\text { Methyl } \\
\text { para- } \\
\text { thion, } \\
\text { water, } \\
\text { fltrd } \\
\odot .7 \text { u GF } \\
\text { ug/L } \\
(82667)\end{array}$ & $\begin{array}{c}\text { Metola- } \\
\text { chlor, } \\
\text { water, } \\
\text { fltrd, } \\
\text { ug/L } \\
(39415)\end{array}$ & $\begin{array}{c}\text { Metri- } \\
\text { buzin, } \\
\text { water, } \\
\text { fltrd, } \\
\text { ug/L } \\
\text { (82630) }\end{array}$ & $\begin{array}{c}\text { Metsul- } \\
\text { furon- } \\
\text { methyl, } \\
\text { water, } \\
\text { fltrd, } \\
\text { ug/L } \\
(61697)\end{array}$ & $\begin{array}{c}\text { Moli- } \\
\text { nate, } \\
\text { water, } \\
\text { fltrd } \\
\odot .7 \mathrm{u} \mathrm{GF} \\
\text { ug/L } \\
(82671)\end{array}$ & $\begin{array}{c}\text { Myclo- } \\
\text { butanil } \\
\text { water, } \\
\text { fltrd, } \\
\text { ug/L } \\
(61599)\end{array}$ & $\begin{array}{c}\mathrm{N}-(4- \\
\text { Chloro- } \\
\text { phenyl) } \\
-\mathrm{N}^{\prime}- \\
\text { methyl- } \\
\text { urea, } \\
\text { ug/L } \\
(61692)\end{array}$ & $\begin{array}{c}\text { Neburon } \\
\text { water, } \\
\text { fltrd } \\
\odot .7 \mathrm{u} \mathrm{GF} \\
\text { ug/L } \\
(49294)\end{array}$ & $\begin{array}{c}\text { Nico- } \\
\text { sul- } \\
\text { furon, } \\
\text { water, } \\
\text { fltrd, } \\
\text { ug/L } \\
(50364)\end{array}$ & $\begin{array}{c}\text { Norflur } \\
\text { azon, } \\
\text { water, } \\
\text { fltrd } \\
\odot .7 \mathrm{u} \mathrm{GF} \\
\text { ug/L } \\
(49293)\end{array}$ & $\begin{array}{c}\text { Ory- } \\
\text { zalin, } \\
\text { water, } \\
\text { fltrd } \\
\odot .7 \mathrm{u} \mathrm{GF} \\
\text { ug/L } \\
(49292)\end{array}$ \\
\hline 471142122094701 & $09-21-10$ & $<.008$ & $<.014$ & $<.012$ & $<.14$ & $<.003$ & $<.010$ & $<.06$ & $<.02$ & $<.10$ & $<.04$ & $<.04$ \\
\hline $\begin{array}{l}471324122093901 \\
471423122115001\end{array}$ & $\begin{array}{l}09-22-10 \\
09-22-10\end{array}$ & $\begin{array}{l}<.008 \\
<.008\end{array}$ & $\begin{array}{l}<.014 \\
<.014\end{array}$ & $\begin{array}{l}<.012 \\
<.012\end{array}$ & $\begin{array}{l}<.14 \\
<.14\end{array}$ & $\begin{array}{l}<.003 \\
<.003\end{array}$ & $\begin{array}{l}<.010 \\
<.010\end{array}$ & $\begin{array}{l}<.06 \\
<.06\end{array}$ & $\begin{array}{l}<.02 \\
<.02\end{array}$ & $\begin{array}{l}<.10 \\
<.10\end{array}$ & $\begin{array}{l}<.04 \\
<.04\end{array}$ & $\begin{array}{l}<.04 \\
<.04\end{array}$ \\
\hline
\end{tabular}


Appendix G. Pesticides, Wastewater Indicator Chemicals, and Pharmaceuticals in Samples from Allan Yorke (map No. L2), Snag Island (map No. L5), and Lake Outlet (map No. L8) Study Sites on Lake Tapps, Washington, September 2010

[See Appendix C for full names of chemical compounds and other details. Remark codes used in this table: <, less than; E, estimated; M, presence verified, but not quantified; ug/L, micrograms per liter; \%, percent]

\begin{tabular}{|c|c|c|c|c|c|c|c|c|c|c|c|c|}
\hline Station number & Date & $\begin{array}{c}\text { Oxamyl, } \\
\text { water, } \\
\text { fltrd } \\
0.7 \mathrm{GuF} \\
\text { ug/L } \\
(38866)\end{array}$ & $\begin{array}{c}\text { oxy- } \\
\text { fluor- } \\
\text { fen, } \\
\text { water, } \\
\text { fltrd, } \\
\text { ug/L } \\
(61600)\end{array}$ & $\begin{array}{c}\text { p- } \\
\text { cresol, } \\
\text { water, } \\
\text { fltrd, } \\
\text { ug/L } \\
(62084)\end{array}$ & $\begin{array}{c}\text { Pendi- } \\
\text { meth- } \\
\text { alin, } \\
\text { water, } \\
\text { fltrd } \\
\odot .7 \mathrm{u} \mathrm{GF} \\
\text { ug/L } \\
(82683)\end{array}$ & $\begin{array}{c}\text { Phorate } \\
\text { oxon, } \\
\text { water, } \\
\text { fltrd, } \\
\text { ug/L } \\
(6166)\end{array}$ & $\begin{array}{c}\text { Phorate } \\
\text { water, } \\
\text { fltrd } \\
\text { ๑.7u GF } \\
\text { ug/L } \\
(82664)\end{array}$ & $\begin{array}{c}\text { Phosmet } \\
\text { oxon, } \\
\text { water, } \\
\text { fltrd, } \\
\text { ug/L' } \\
(61668)\end{array}$ & $\begin{array}{c}\text { Phosmet } \\
\text { water, } \\
\text { fltrd, } \\
\text { ug/L } \\
(61601)\end{array}$ & $\begin{array}{c}\text { Pic- } \\
\text { loram, } \\
\text { water, } \\
\text { fltrd } \\
\Theta .7 \mathrm{GG} \\
\text { ug/L } \\
(49291)\end{array}$ & $\begin{array}{l}\text { Piper- } \\
\text { onyl } \\
\text { but- } \\
\text { oxide, } \\
\text { water, } \\
\text { fltrd, } \\
\text { ug/L } \\
(67826)\end{array}$ & $\begin{array}{c}\text { Prome- } \\
\text { ton, } \\
\text { water, } \\
\text { fltrd, } \\
\text { ug/L } \\
(04037)\end{array}$ \\
\hline 71142122094701 & $9-21-10$ & $<.12$ & $<.010$ & $<.40$ & $<.012$ & $<.03$ & $<.020$ & $<.05$ & $<.034$ & $<.12$ & $<1$ & .009 \\
\hline & & & $<.010$ & & & & & & & & & .013 \\
\hline 471423122115001 & $09-22-10$ & $<.12$ & $<.010$ & $<.40$ & $<.012$ & $<.03$ & $<.02$ & $<. \theta$ & $<.03$ & $<.1$ & $<.1$ & .013 \\
\hline Station number & Date & $\begin{array}{c}\text { Prome- } \\
\text { tryn, } \\
\text { water, } \\
\text { fltrd, } \\
\text { ug/L } \\
(04036)\end{array}$ & $\begin{array}{c}\text { Pro- } \\
\text { panil, } \\
\text { water, } \\
\text { fltrd } \\
0.7 \mathrm{Gu} \text { GF } \\
\text { ug/L } \\
(82679)\end{array}$ & $\begin{array}{c}\text { Propar- } \\
\text { gite, } \\
\text { water, } \\
\text { fltrd } \\
0.7 \mathrm{Gu} \\
\text { ug/L } \\
(82685)\end{array}$ & $\begin{array}{c}\text { Propham } \\
\text { water, } \\
\text { fltrd } \\
\text { ๑.7u GF } \\
\text { ug/L } \\
(49236)\end{array}$ & $\begin{array}{c}\text { Propi- } \\
\text { cona- } \\
\text { zole, } \\
\text { water, } \\
\text { fltrd, } \\
\text { ug/L } \\
(50471)\end{array}$ & $\begin{array}{c}\text { Pro- } \\
\text { poxur, } \\
\text { water, } \\
\text { fltrd } \\
\text { ๑. } 7 \text { u GF } \\
\text { ug/L } \\
(38538)\end{array}$ & $\begin{array}{c}\text { Propy- } \\
\text { zamide, } \\
\text { water, } \\
\text { fltrd } \\
0.7 \mathrm{GGF} \\
\text { ug/L } \\
(82676)\end{array}$ & $\begin{array}{c}\text { Siduron } \\
\text { water, } \\
\text { fltrd, } \\
\text { ug/L } \\
(38548)\end{array}$ & $\begin{array}{c}\text { Sima- } \\
\text { zine, } \\
\text { water, } \\
\text { fltrd, } \\
\text { ug/L } \\
(04035)\end{array}$ & $\begin{array}{c}\text { Sulfo- } \\
\text { met- } \\
\text { ruron- } \\
\text { methyl, } \\
\text { water, } \\
\text { fltrd, } \\
\text { ug/L' } \\
(50337)\end{array}$ & $\begin{array}{c}\text { Tebu- } \\
\text { thiuron } \\
\text { water, } \\
\text { fltrd } \\
0.7 \mathrm{G} \mathrm{GF} \\
\text { ug/L } \\
(82670)\end{array}$ \\
\hline 471142122094701 & $09-21-10$ & $<.006$ & $<.010$ & $<.02$ & $<.040$ & $<.04$ & $<.060$ & $<.004$ & $<.04$ & $<.006$ & $<.060$ & $<.03$ \\
\hline 471324122093901 & $-22-10$ & $<.006$ & $<.01$ & $<.0$ & & & & & $<$. & & & \\
\hline 471423122115001 & $09-22-10$ & $<.006$ & $<.010$ & $<.02$ & $<.040$ & $<.04$ & $<.060$ & $<.004$ & $<.04$ & $<.006$ & $<.060$ & $<.03$ \\
\hline Station & Date & $\begin{array}{c}\text { Teflu- } \\
\text { thrin, } \\
\text { water, } \\
\text { fltrd, } \\
\text { ug/L } \\
(61606)\end{array}$ & $\begin{array}{c}\text { Terba- } \\
\text { cil, } \\
\text { water, } \\
\text { fltrd, } \\
\text { ug/L } \\
(04032)\end{array}$ & $\begin{array}{c}\text { Ter- } \\
\text { bufos } \\
\text { oxon } \\
\text { sulfone } \\
\text { water, } \\
\text { fltrd, } \\
\text { ug/L } \\
(61674)\end{array}$ & $\begin{array}{c}\text { Terbu- } \\
\text { fos, } \\
\text { water, } \\
\text { fltrd } \\
0.7 \mathrm{tu} \text { GF } \\
\text { ug/L } \\
(82675)\end{array}$ & $\begin{array}{c}\text { Ter- } \\
\text { buthyl- } \\
\text { azine, } \\
\text { water, } \\
\text { flttrd, } \\
\text { ug/L } \\
(04022)\end{array}$ & $\begin{array}{c}\text { Thiaben } \\
\text { dazole, } \\
\text { water, } \\
\text { fltrd, } \\
\text { ug/L } \\
(62801)\end{array}$ & $\begin{array}{c}\text { Thio- } \\
\text { bencarb } \\
\text { water, } \\
\text { fltrd } \\
\text { 0.7u GF } \\
\text { ug/L } \\
(82681)\end{array}$ & $\begin{array}{l}\text { trans- } \\
\text { Propi- } \\
\text { cona- } \\
\text { zole, } \\
\text { water, } \\
\text { fltrd, } \\
\text { ug/L } \\
(79847)\end{array}$ & $\begin{array}{c}\text { Tribu- } \\
\text { phos, } \\
\text { water, } \\
\text { fltrd, } \\
\text { ug/L } \\
(61610)\end{array}$ & $\begin{array}{c}\text { Tri- } \\
\text { clopyr, } \\
\text { water, } \\
\text { fltrd } \\
0.7 \mathrm{GuF} \\
\text { ug/L } \\
(49235)\end{array}$ & $\begin{array}{c}\text { Tri- } \\
\text { flur- } \\
\text { alin, } \\
\text { water, } \\
\text { fltrd } \\
\text { ๑.7u GF } \\
\text { ug/L } \\
(82661)\end{array}$ \\
\hline 471142122094701 & & $<.010$ & $<.046$ & $<.0$ & & & & & & & $<.08$ & $<.0$ \\
\hline 471324122093901 & 10 & & & & & & & & & & & $<.0$ \\
\hline 471423122115001 & $09-22-10$ & $<.010$ & $<.040$ & $<.04$ & $<.02$ & $<.01$ & $<.060$ & $<.016$ & $<.02$ & $<.018$ & $<.08$ & $<.018$ \\
\hline Station & Date & $\begin{array}{c}\text { 1, 7-Di- } \\
\text { methyl- } \\
\text { Xan- } \\
\text { thine, } \\
\text { water, } \\
\text { fltrd, } \\
\text { ug/L } \\
(62030)\end{array}$ & $\begin{array}{c}1- \\
\text { Methyl- } \\
\text { naphth- } \\
\text { alene, } \\
\text { water, } \\
\text { fltrd, } \\
\text { ug/L } \\
(62054)\end{array}$ & $\begin{array}{l}\text { 2,6-Di- } \\
\text { methyl- } \\
\text { naphth- } \\
\text { alene, } \\
\text { water, } \\
\text { fltrd, } \\
\text { ug/L } \\
(62055)\end{array}$ & $\begin{array}{c}2 \text {-Ethyl } \\
-2- \\
\text { phenyl- } \\
\text { malon- } \\
\text { amide, } \\
\text { wat flt } \\
\text { ug/L } \\
(67804)\end{array}$ & $\begin{array}{c}2- \\
\text { Methyl- } \\
\text { naphth- } \\
\text { alene, } \\
\text { water, } \\
\text { fltrd, } \\
\text { ug/L } \\
(62056)\end{array}$ & $\begin{array}{c}\text { 3-beta- } \\
\text { Copros- } \\
\text { tanol, } \\
\text { water, } \\
\text { fltrd, } \\
\text { ug/L } \\
(62057)\end{array}$ & $\begin{array}{c}\text { 3- } \\
\text { Methyl- } \\
1 H- \\
\text { indole, } \\
\text { water, } \\
\text { fltrd, } \\
\text { ug/L } \\
(62058)\end{array}$ & $\begin{array}{l}\text { 3-tert- } \\
\text { Butyl- } \\
4 \text {-hy- } \\
\text { droxy- } \\
\text { anisole } \\
\text { wat flt } \\
\text { ug/L } \\
(62059)\end{array}$ & $\begin{array}{c}4- \\
\text { Cumyl- } \\
\text { phenol, } \\
\text { water, } \\
\text { fltrd, } \\
\text { ug/L } \\
(62060)\end{array}$ & $\begin{array}{c}4-n- \\
\text { octyl- } \\
\text { phenol, } \\
\text { water, } \\
\text { fltrd, } \\
\text { ug/L } \\
(62061)\end{array}$ & $\begin{array}{c}4- \\
\text { Nonyl- } \\
\text { phenol, } \\
\text { all } \\
\text { isomers } \\
\text { wat flt } \\
\text { ug/L } \\
(62085)\end{array}$ \\
\hline & & & & & & & & & & & & \\
\hline 47132 & & & & & & & & & & & & \\
\hline 471423122115001 & $09-22-10$ & $<.100$ & $<.022$ & $<.1$ & $<.1$ & $<.036$ & $<2$ & $<.036$ & $<8$ & 8.0 & .16 & $<2$ \\
\hline Station & Date & $\begin{array}{c}\text { 4- Nonyl } \\
\text {-phenol } \\
\text { di- } \\
\text { ethox- } \\
\text { ylate, } \\
\text { wat flt } \\
\text { ug/L } \\
(62083)\end{array}$ & $\begin{array}{c}\text { 4t-octy } \\
\text { lphenol } \\
\text { di- } \\
\text { ethox- } \\
\text { ylate, } \\
\text { wat flt } \\
\text { ug/L } \\
(61705)\end{array}$ & $\begin{array}{c}\text { 4t-octy } \\
\text { phenol } \\
\text { mono- } \\
\text { ethox- } \\
\text { ylate, } \\
\text { wat flt } \\
\text { ug/L } \\
(61706)\end{array}$ & $\begin{array}{c}\text { 4-tert- } \\
\text { octyl- } \\
\text { phenol, } \\
\text { water, } \\
\text { fltrd, } \\
\text { ug/L } \\
(62062)\end{array}$ & $\begin{array}{c}\text { 5-Meth- } \\
\text { yl-1H- } \\
\text { benzo- } \\
\text { tri- } \\
\text { azole, } \\
\text { wat flt } \\
\text { ug/L } \\
(62063)\end{array}$ & $\begin{array}{c}9,10- \\
\text { Anthra- } \\
\text { quinone } \\
\text { water, } \\
\text { fltrd, } \\
\text { ug/L } \\
(62066)\end{array}$ & $\begin{array}{l}\text { Acet- } \\
\text { amino- } \\
\text { phen, } \\
\text { water, } \\
\text { fltrd, } \\
\text { ug/L } \\
(62000)\end{array}$ & $\begin{array}{c}\text { Aceto- } \\
\text { phenone } \\
\text { water, } \\
\text { fltrd, } \\
\text { ug/L } \\
(62064)\end{array}$ & $\begin{array}{c}\text { AHTN, } \\
\text { water, } \\
\text { fltrd, } \\
\text { ug/L } \\
(62065)\end{array}$ & $\begin{array}{c}\text { Albut - } \\
\text { erol, } \\
\text { water, } \\
\text { fltrd, } \\
\text { ug/L } \\
(6202 \theta)\end{array}$ & $\begin{array}{c}\text { Amitri- } \\
\text { ptyline } \\
\text { water, } \\
\text { fltrd, } \\
\text { ug/L } \\
(67962)\end{array}$ \\
\hline 471142122094 & & $<$ & $<1$ & $<$ & & $<$ & & & & & & \\
\hline & & & $<1$ & & & & & & & & & \\
\hline 471423122115001 & $09-22-10$ & $<5$ & $<1$ & $<1$ & $<.14$ & $<1$ & $<.2$ & $<.120$ & $<.4$ & $<.028$ & $<.080$ & $<.16$ \\
\hline Station & Date & $\begin{array}{c}\text { Anthra- } \\
\text { cene, } \\
\text { water, } \\
\text { fltrd, } \\
\text { ug/L } \\
(34221)\end{array}$ & $\begin{array}{c}\text { Anti- } \\
\text { pyrine, } \\
\text { water, } \\
\text { fltrd, } \\
\text { ug/L } \\
(67805)\end{array}$ & $\begin{array}{c}\text { Benzo- } \\
{[a]-} \\
\text { pyrene, } \\
\text { water, } \\
\text { fltrd, } \\
\text { ug/L } \\
(34248)\end{array}$ & $\begin{array}{c}\text { Benzo- } \\
\text { phenone } \\
\text { water, } \\
\text { fltrd, } \\
\text { ug/L } \\
(62067)\end{array}$ & $\begin{array}{c}\text { beta- } \\
\text { Sitos- } \\
\text { terol, } \\
\text { water, } \\
\text { fltrd, } \\
\text { ug/L } \\
(62068)\end{array}$ & $\begin{array}{c}\text { beta- } \\
\text { stigmas } \\
\text { tanol, } \\
\text { water, } \\
\text { fltrd, } \\
\text { ug/L } \\
(62086)\end{array}$ & $\begin{array}{c}\text { Butal- } \\
\text { bital, } \\
\text { water, } \\
\text { fltrd, } \\
\text { ug/L } \\
\text { (63768) }\end{array}$ & $\begin{array}{c}\text { Caf- } \\
\text { feine, } \\
\text { water, } \\
\text { fltrd, } \\
\text { ug/L } \\
(50305)\end{array}$ & $\begin{array}{c}\text { Carbam- } \\
\text { azepine } \\
\text { water, } \\
\text { fltrd, } \\
\text { ug/L } \\
(62793)\end{array}$ & $\begin{array}{c}\text { Cariso- } \\
\text { prodol, } \\
\text { water, } \\
\text { fltrd, } \\
\text { ug/L } \\
(65180)\end{array}$ & $\begin{array}{c}\text { Cele- } \\
\text { coxib, } \\
\text { water, } \\
\text { fltrd, } \\
\text { ug/L } \\
(67806)\end{array}$ \\
\hline & & & & & & & & & & & & \\
\hline $\begin{array}{l}471324122093901 \\
471423122115001\end{array}$ & $\begin{array}{l}09-22-10 \\
09-22-10\end{array}$ & $\begin{array}{l}<.028 \\
<.028\end{array}$ & & & & & & & & & & $<.6$ \\
\hline
\end{tabular}


Appendix G. Pesticides, Wastewater Indicator Chemicals, and Pharmaceuticals in Samples from Allan Yorke (map No. L2), Snag Island (map No. L5), and Lake Outlet (map No. L8) Study Sites on Lake Tapps, Washington, September 2010

[See Appendix C for full names of chemical compounds and other details. Remark codes used in this table: <, less than; E, estimated; M, presence verified, but not quantified; ug/L, micrograms per liter; \%, percent]

\begin{tabular}{|c|c|c|c|c|c|c|c|c|c|c|c|c|}
\hline Station & Date & $\begin{array}{c}\text { Chirald } \\
\text { water, } \\
\text { fltrd, } \\
\text { ug/L } \\
(67960)\end{array}$ & $\begin{array}{c}\text { Chloro- } \\
\text { xylenol } \\
\text { water, } \\
\text { fltrd, } \\
\text { ug/L } \\
(66574)\end{array}$ & $\begin{array}{c}\text { Chlor - } \\
\text { phenir - } \\
\text { amine, } \\
\text { water, } \\
\text { fltrd, } \\
\text { ug/L } \\
(63769)\end{array}$ & $\begin{array}{c}\text { Choles- } \\
\text { terol, } \\
\text { water, } \\
\text { fltrd, } \\
\text { ug/L } \\
(62072)\end{array}$ & $\begin{array}{c}\text { Citalo- } \\
\text { pram, } \\
\text { water, } \\
\text { fltrd, } \\
\text { ug/L } \\
(67807)\end{array}$ & $\begin{array}{c}\text { Codeine } \\
\text { water, } \\
\text { fltrd, } \\
\text { ug/L } \\
(62003)\end{array}$ & $\begin{array}{c}\text { Cot- } \\
\text { inine, } \\
\text { water, } \\
\text { fltrd, } \\
\text { ug/L } \\
\text { (62005) }\end{array}$ & $\begin{array}{c}\text { De- } \\
\text { hydro- } \\
\text { nife- } \\
\text { dipine, } \\
\text { water, } \\
\text { fltrd, } \\
\text { ug/L } \\
(62004)\end{array}$ & $\begin{array}{c}\text { Dextro- } \\
\text { meth- } \\
\text { orphan, } \\
\text { water, } \\
\text { fltrd, } \\
\text { ug/L } \\
(67809)\end{array}$ & $\begin{array}{l}\text { Diaz- } \\
\text { epam, } \\
\text { water, } \\
\text { fltrd, } \\
\text { ug/L } \\
(63770)\end{array}$ & $\begin{array}{c}\text { Di- } \\
\text { hydro- } \\
\text { codeine } \\
\text { water, } \\
\text { fltrd, } \\
\text { ug/L } \\
(67810)\end{array}$ \\
\hline 471142122094701 & $09-21-10$ & $<.16$ & $<.1$ & $<.08$ & $<2$ & $<.1$ & $<.3$ & $<.038$ & $<.080$ & $<.2$ & $<.16$ & $<.2$ \\
\hline $\begin{array}{l}471324122093901 \\
471423122115001\end{array}$ & $\begin{array}{l}09-22-10 \\
09-22-10\end{array}$ & $<.16$ & $<.1$ & $\begin{array}{l}<.08 \\
<08\end{array}$ & $\begin{array}{l}<2 \\
<2\end{array}$ & $<.1$ & $\begin{array}{l}<.3 \\
<.3\end{array}$ & $\begin{array}{l}<.038 \\
<.038\end{array}$ & $\begin{array}{l}<.080 \\
<.080\end{array}$ & $<.2$ & $<.16$ & $\begin{array}{l}<.2 \\
<.2\end{array}$ \\
\hline Station & Date & $\begin{array}{c}\text { Diltia- } \\
\text { zem, } \\
\text { water, } \\
\text { fltrd, } \\
\text { ug/L } \\
(62008)\end{array}$ & $\begin{array}{c}\text { Diphen- } \\
\text { hydra- } \\
\text { mine, } \\
\text { water, } \\
\text { fltrd, } \\
\text { ug/L } \\
(62796)\end{array}$ & $\begin{array}{c}\text { D-Limo- } \\
\text { nene, } \\
\text { water, } \\
\text { fltrd, } \\
\text { ug/L } \\
(62073)\end{array}$ & $\begin{array}{c}\text { Efa- } \\
\text { virenz, } \\
\text { water, } \\
\text { fltrd, } \\
\text { ug/L } \\
\text { (67811) }\end{array}$ & $\begin{array}{c}\text { Flucon- } \\
\text { azole, } \\
\text { water, } \\
\text { fltrd, } \\
\text { ug/L } \\
(67812)\end{array}$ & $\begin{array}{c}\text { Fluor- } \\
\text { anthene } \\
\text { water, } \\
\text { fltrd, } \\
\text { ug/L } \\
(34377)\end{array}$ & $\begin{array}{c}\text { Griseo- } \\
\text { fulvin, } \\
\text { water, } \\
\text { fltrd, } \\
\text { ug/L } \\
(67813)\end{array}$ & $\begin{array}{c}\text { HHCB, } \\
\text { water, } \\
\text { fltrd, } \\
\text { ug/L } \\
(62075)\end{array}$ & $\begin{array}{c}\text { Hydro- } \\
\text { codone, } \\
\text { water, } \\
\text { fltrd, } \\
\text { ug/L } \\
(63771)\end{array}$ & $\begin{array}{c}\text { Imino- } \\
\text { stil- } \\
\text { bene, } \\
\text { water, } \\
\text { fltrd, } \\
\text { ug/L } \\
(67815)\end{array}$ & $\begin{array}{c}\text { Indole, } \\
\text { water, } \\
\text { fltrd, } \\
\text { ug/L } \\
(62076)\end{array}$ \\
\hline 471142122094701 & $09-21-10$ & $<.04$ & $<.1$ & $<.1$ & $<.3$ & $<.2$ & $<.024$ & $<.3$ & .1 & $<.3$ & $<.1$ & $<.1$ \\
\hline 471324122093901 & $09-22-10$ & $<.04$ & $<.1$ & $<.1$ & $<.3$ & $<.2$ & $<.024$ & $<.3$ & $<.1$ & $<.3$ & $<.1$ & $<.1$ \\
\hline 471423122115001 & $09-22-10$ & $<.04$ & $<.1$ & $<.1$ & $<.3$ & $<.2$ & $<.024$ & $<.3$ & $<.1$ & $<.3$ & $<.1$ & $<.1$ \\
\hline Station & Date & $\begin{array}{c}\text { Isobor- } \\
\text { neol, } \\
\text { water, } \\
\text { fltrd, } \\
\text { ug/L } \\
(62077)\end{array}$ & $\begin{array}{c}\text { Iso- } \\
\text { phorone } \\
\text { water, } \\
\text { fltrd, } \\
\text { ug/L } \\
(34409)\end{array}$ & $\begin{array}{c}\text { Iso- } \\
\text { propyl- } \\
\text { benzene } \\
\text { water, } \\
\text { fltrd, } \\
\text { ug/L } \\
(62078)\end{array}$ & $\begin{array}{c}\text { Iso- } \\
\text { quin- } \\
\text { oline, } \\
\text { water, } \\
\text { fltrd, } \\
\text { ug/L } \\
(62079)\end{array}$ & $\begin{array}{c}\text { Lido- } \\
\text { caine, } \\
\text { water, } \\
\text { fltrd, } \\
\text { ug/L } \\
(67816)\end{array}$ & $\begin{array}{c}\text { Menthol } \\
\text { water, } \\
\text { fltrd, } \\
\text { ug/L } \\
(62080)\end{array}$ & $\begin{array}{c}\text { Meper - } \\
\text { idine, } \\
\text { water, } \\
\text { fltrd, } \\
\text { ug/L } \\
(67818)\end{array}$ & $\begin{array}{c}\text { Mepro- } \\
\text { bamate, } \\
\text { water, } \\
\text { fltrd, } \\
\text { ug/L } \\
(67819)\end{array}$ & $\begin{array}{c}\text { Metax- } \\
\text { alone, } \\
\text { water, } \\
\text { fltrd, } \\
\text { ug/L } \\
(63772)\end{array}$ & $\begin{array}{c}\text { Meth- } \\
\text { adone, } \\
\text { water, } \\
\text { fltrd, } \\
\text { ug/L } \\
(63774)\end{array}$ & $\begin{array}{c}\text { Methyl } \\
\text { salicy- } \\
\text { late, } \\
\text { water, } \\
\text { fltrd, } \\
\text { ug/L } \\
\text { (62081) }\end{array}$ \\
\hline 471142122094701 & $09-21-10$ & $<.2$ & M & $<.3$ & $<.2$ & $<.1$ & $<.3$ & $<.1$ & $<.3$ & $<.08$ & $<.1$ & $<.044$ \\
\hline 471324122093901 & $09-22-10$ & $<.2$ & M & $<.3$ & $<.046$ & $<.1$ & $<.3$ & $<.1$ & $<.3$ & $<.08$ & $<.1$ & M \\
\hline 471423122115001 & $09-22-10$ & $<.2$ & $<.1$ & $<.3$ & $<.2$ & $<.1$ & $<.3$ & $<.1$ & $<.3$ & $<.08$ & $<.1$ & $<.044$ \\
\hline Station & Date & $\begin{array}{c}\text { Methyl- } \\
\text { phen-- } \\
\text { idate, } \\
\text { water, } \\
\text { fltrd, } \\
\text { ug/L } \\
(67820)\end{array}$ & $\begin{array}{c}\text { Naphth- } \\
\text { alene, } \\
\text { water, } \\
\text { fltrd, } \\
\text { ug/L } \\
(34443)\end{array}$ & $\begin{array}{c}\text { Norpro- } \\
\text { poxy- } \\
\text { phene, } \\
\text { water, } \\
\text { fltrd, } \\
\text { ug/L } \\
(67821)\end{array}$ & $\begin{array}{c}\text { Ox- } \\
\text { carbaz- } \\
\text { epine, } \\
\text { water, } \\
\text { fltrd, } \\
\text { ug/L } \\
(67822)\end{array}$ & $\begin{array}{c}\text { oxy- } \\
\text { codone, } \\
\text { water, } \\
\text { fltrd, } \\
\text { ug/L } \\
(63775)\end{array}$ & $\begin{array}{c}\text { Pento- } \\
\text { bar- } \\
\text { bital, } \\
\text { water, } \\
\text { fltrd, } \\
\text { ug/L } \\
(67823)\end{array}$ & $\begin{array}{c}\text { Pentox- } \\
\text { ifyl- } \\
\text { line, } \\
\text { water, } \\
\text { fltrd, } \\
\text { ug/L } \\
(67824)\end{array}$ & $\begin{array}{c}\text { Phenan- } \\
\text { threne, } \\
\text { water, } \\
\text { fltrd, } \\
\text { ug/L } \\
(34462)\end{array}$ & $\begin{array}{c}\text { Phendi- } \\
\text { metra- } \\
\text { zine, } \\
\text { water, } \\
\text { fltrd, } \\
\text { ug/L } \\
(63776)\end{array}$ & $\begin{array}{c}\text { Pheno- } \\
\text { bar- } \\
\text { bital, } \\
\text { water, } \\
\text { fltrd, } \\
\text { ug/L } \\
(67319)\end{array}$ & $\begin{array}{c}\text { Phenol, } \\
\text { water, } \\
\text { fltrd, } \\
\text { ug/L } \\
(34466)\end{array}$ \\
\hline 471142122094701 & $09-21-10$ & - - & $<.040$ & $<.3$ & - - & $<.3$ & $<.2$ & $<.3$ & $<.032$ & - - & $<.2$ & $<.2$ \\
\hline 471324122093901 & $09-22-10$ & $<.1$ & $<.040$ & $<.3$ & $<.3$ & $<.3$ & $<.2$ & $<.3$ & $<.032$ & $<.04$ & $<.2$ & $<.2$ \\
\hline 471423122115001 & $09-22-10$ & -- & $<.040$ & $<.3$ & -- & $<.3$ & $<.2$ & $<.3$ & $<.032$ & -- & $<.2$ & $<.2$ \\
\hline Station & Date & $\begin{array}{l}\text { Pheny- } \\
\text { toin, } \\
\text { water, } \\
\text { fltrd, } \\
\text { ug/L } \\
\text { (67825) }\end{array}$ & $\begin{array}{c}\text { Prim- } \\
\text { idone, } \\
\text { water, } \\
\text { fltrd, } \\
\text { ug/L } \\
(67827)\end{array}$ & $\begin{array}{c}\text { Propo- } \\
\text { fol, } \\
\text { water, } \\
\text { fltrd, } \\
\text { ug/L } \\
\text { (67828) }\end{array}$ & $\begin{array}{c}\text { Pyrene, } \\
\text { water, } \\
\text { fltrd, } \\
\text { ug/L } \\
(34470)\end{array}$ & $\begin{array}{c}\text { Sulfa- } \\
\text { methox- } \\
\text { azole, } \\
\text { water, } \\
\text { fltrd, } \\
\text { ug/L } \\
(62021)\end{array}$ & $\begin{array}{l}\text { Temaz - } \\
\text { epam, } \\
\text { water, } \\
\text { fltrd, } \\
\text { ug/L } \\
(67830)\end{array}$ & $\begin{array}{c}\text { Tetra- } \\
\text { chloro- } \\
\text { ethene, } \\
\text { water, } \\
\text { fltrd, } \\
\text { ug/L } \\
(34476)\end{array}$ & $\begin{array}{c}\text { Ticlo- } \\
\text { pidine, } \\
\text { water, } \\
\text { fltrd, } \\
\text { ug/L } \\
(67831)\end{array}$ & $\begin{array}{c}\text { Trama- } \\
\text { dol, } \\
\text { water, } \\
\text { fltrd, } \\
\text { ug/L } \\
\text { (67832) }\end{array}$ & $\begin{array}{c}\text { Tri- } \\
\text { bromo- } \\
\text { methane } \\
\text { water, } \\
\text { fltrd, } \\
\text { ug/L } \\
(34288)\end{array}$ & $\begin{array}{c}\text { Tri- } \\
\text { butyl } \\
\text { phos- } \\
\text { phate, } \\
\text { water, } \\
\text { fltrd, } \\
\text { ug/L } \\
(62089)\end{array}$ \\
\hline 471142122094701 & $09-21-10$ & $<.2$ & $<.3$ & $<.04$ & $<.042$ & $<.160$ & $<.3$ & $<.1$ & $<.1$ & $<.04$ & $<.1$ & $<.2$ \\
\hline 471324122093901 & $09-22-10$ & $<.2$ & $<.3$ & $<.04$ & $<.042$ & $<.160$ & - - & $<.1$ & $<.1$ & $<.04$ & $<.1$ & $<.2$ \\
\hline 471423122115001 & $09-22-10$ & $<.2$ & $<.3$ & $<.04$ & $<.042$ & $<.160$ & $<.3$ & $<.1$ & $<.1$ & $<.04$ & $<.1$ & $<.2$ \\
\hline Station & Date & $\begin{array}{c}\text { Triclo- } \\
\text { san, } \\
\text { water, } \\
\text { fltrd, } \\
\text { ug/L } \\
(62090)\end{array}$ & $\begin{array}{c}\text { Tri- } \\
\text { ethyl } \\
\text { citrate } \\
\text { water, } \\
\text { fltrd, } \\
\text { ug/L } \\
(62091)\end{array}$ & $\begin{array}{c}\text { Tri- } \\
\text { meth- } \\
\text { oprim, } \\
\text { water, } \\
\text { fltrd, } \\
\text { ug/L } \\
(62023)\end{array}$ & $\begin{array}{c}\text { Tri- } \\
\text { phenyl } \\
\text { phos- } \\
\text { phate, } \\
\text { water, } \\
\text { fltrd, } \\
\text { ug/L } \\
(62092)\end{array}$ & $\begin{array}{c}\text { Tris(2- } \\
\text { butoxy- } \\
\text { ethyl) } \\
\text { phos- } \\
\text { phate, } \\
\text { wat flt } \\
\text { ug/L } \\
(62093)\end{array}$ & $\begin{array}{c}\text { Tris(2- } \\
\text { chloro- } \\
\text { ethyl) } \\
\text { phos- } \\
\text { phate, } \\
\text { wat flt } \\
\text { ug/L } \\
(62087)\end{array}$ & $\begin{array}{c}\text { Tris(di } \\
\text { chloro- } \\
\text { i-Pr) } \\
\text { phos- } \\
\text { phate, } \\
\text { wat flt } \\
\text { ug/L } \\
(62088)\end{array}$ & $\begin{array}{c}\text { Venla- } \\
\text { faxine, } \\
\text { water, } \\
\text { fltrd, } \\
\text { ug/L } \\
(67833)\end{array}$ & $\begin{array}{c}\text { Vera- } \\
\text { pamil, } \\
\text { water, } \\
\text { fltrd, } \\
\text { ug/L } \\
(67834)\end{array}$ & $\begin{array}{c}\text { Warfar- } \\
\text { in, } \\
\text { water, } \\
\text { fltrd, } \\
\text { ug/L } \\
(62024)\end{array}$ & \\
\hline 471142122094701 & $09-21-10$ & $<.20$ & $<.4$ & $<.034$ & $<.1$ & $<.8$ & $<.1$ & M & $<.04$ & $<.1$ & $<.080$ & \\
\hline 471324122093901 & $09-22-10$ & $<.20$ & $<.4$ & $<.034$ & $<.1$ & $<.8$ & $<.1$ & $<.2$ & $<.04$ & $<.1$ & $<.080$ & \\
\hline 471423122115001 & $09-22-10$ & $<.20$ & $<.4$ & $<.034$ & $<.1$ & $<.8$ & $<.1$ & $<.2$ & $<.04$ & $<.1$ & $<.080$ & \\
\hline
\end{tabular}


Publishing support provided by the U.S. Geological Survey

Publishing Network, Tacoma Publishing Service Center

For more information concerning the research in this report, contact the Director, Washington Water Science Center

U.S. Geological Survey

934 Broadway, Suite 300

Tacoma, Washington 98402

http://wa.water.usgs.gov 


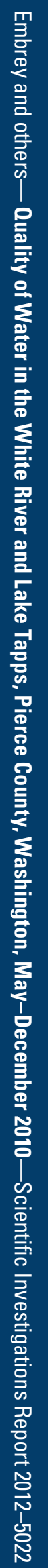

